DEPARTMENT OF THE INTERIOR

John Barton Payne, Secretary

United States Geological Survey

George OtIs Smith, Director

Bulletin 703

THE

\title{
IRON AND ASSOCIATED INDUSTRIES OF LORRAINE, THE SARRE DISTRICT, LUXEMBURG, AND BELGIUM
}

\author{
BY \\ ALFRED H. BROOKS \\ AND \\ MORRIS F. LA CROIX
}

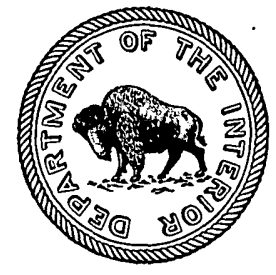

W ASHINGTON

GOVERNMENT PRINTING OFFIOE 1920 



\section{CONTENTS.}

The past and future use of Lorraine iron ore, by Alfred H. Brooks.......... 13

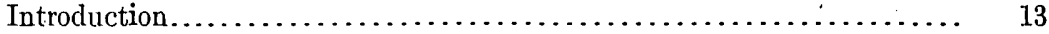

Lorraine iron deposits.................................... 16

General features...................................... 16

Reserves............................................. 18

Geographic relations.................................. 19

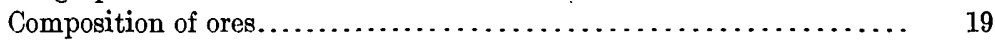

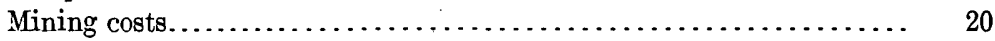

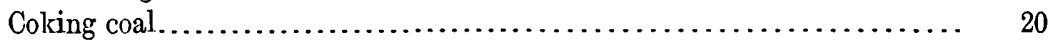

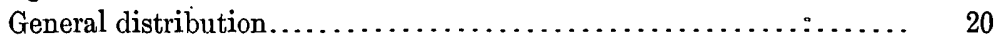

French coal fields.................................... 20

Westphalian coal field................................ 24

Coal fields west of the Rhine.............................. 25

Sarre coal field....................................... $\quad 25$

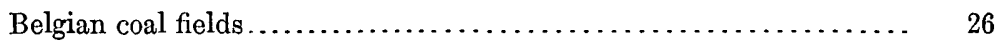

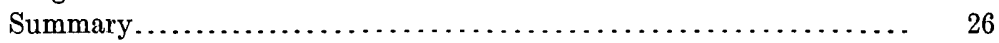

Ownership and value of metallurgic plants and iron lands............. 28

Labor...................................................... 31

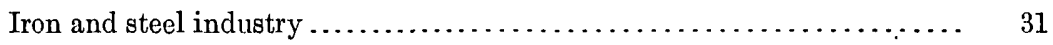

Conditions during reconstruction period $\ldots \ldots \ldots \ldots \ldots \ldots \ldots \ldots \ldots . \quad 31$

Conditions after reconstruction period....................... 34

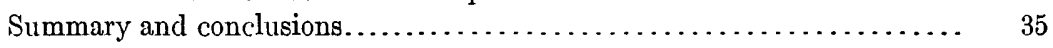

French Lorraine, by Alfred H. Brooks........................ 37

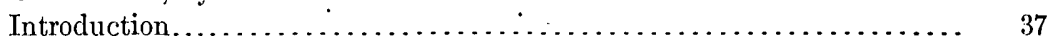

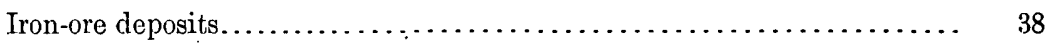

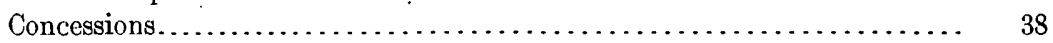

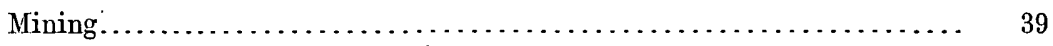

Manufacture of pig iron and steel........................... 42

Ownership of iron lands and metallurgic plants................... 43

Lorraine Annexée, by Alfred H. Brooks........................ 50

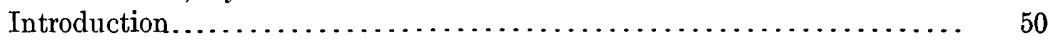

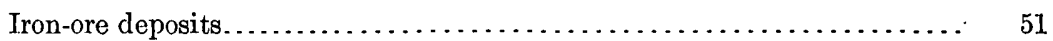

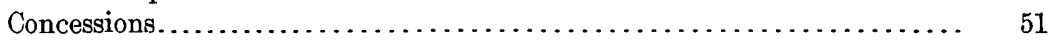

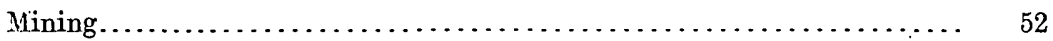

Production of pig iron and steel............................ 54

Ownership of iron lands and metallurgic plants.................. 55

Luxemburg, by Alfred H. Brooks and Morris T. La Croix .............. $\quad 59$

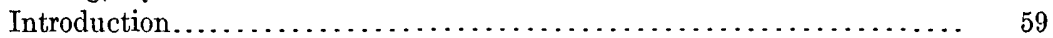

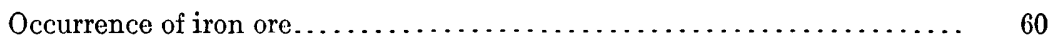

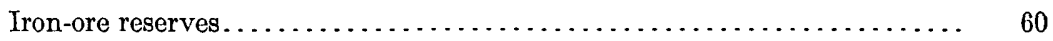

Iron-land concessions.......................................... 60

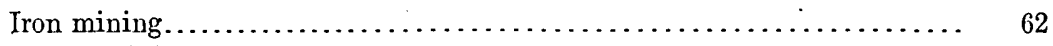

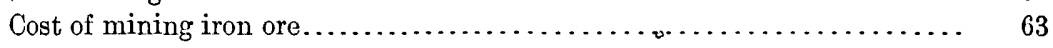

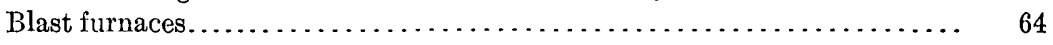

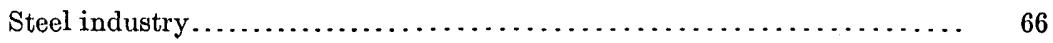


Luxemburg-Continued. : - $\quad$ Page.

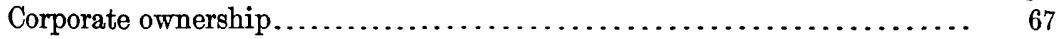

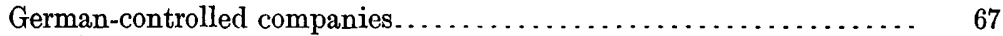

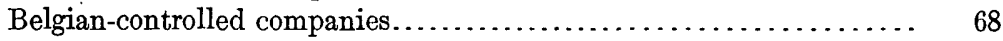

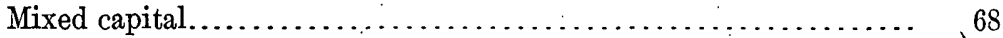

Sarre district, by Alfred $\mathrm{H}$. Brooks........................... 70

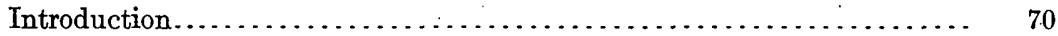

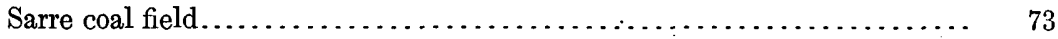

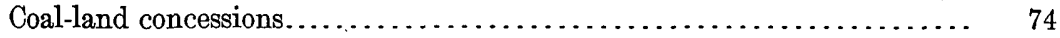

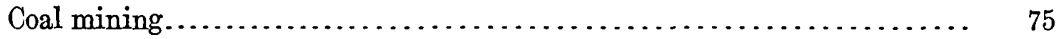

Manufacture of pig iron and steel....................... 77

Ownership of iron and steel plants, coal mines, and coal lands....... 78

Belgium, by Morris F. La Croix........................... 80

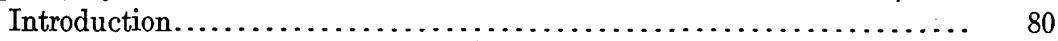

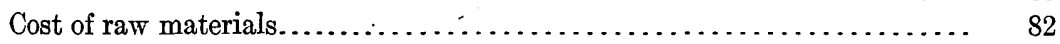

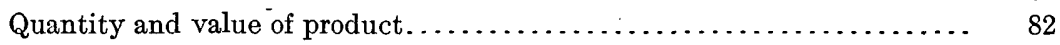

Profits, capital, and real value............................ 83

Value of German interests. ................................ . 84

Production and sources of iron ore.......................... 84

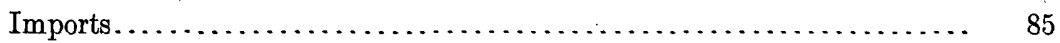

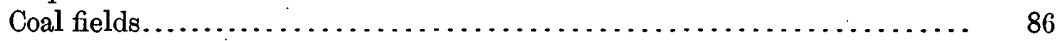

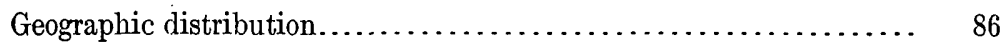

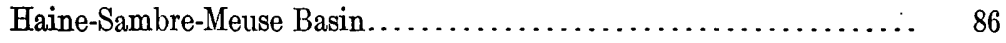

Province of Hainaut.................................. 87

Mons district:............................ 87

Center district. .............................. 87

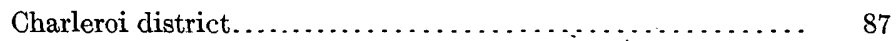

Province of Namur............................. 87

Province of Liége . . . . . . . . . . . . . . . . . . . $8 . \ldots \ldots$

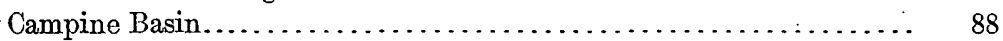

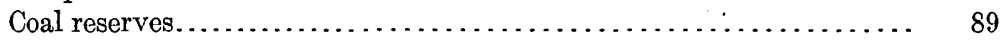

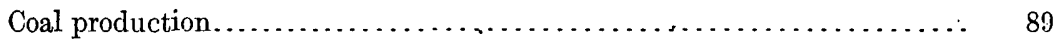

Coal imports and exports.............................. 91

Production and sources of coke.......................... 93

Production and importation of coking coal.................. 94

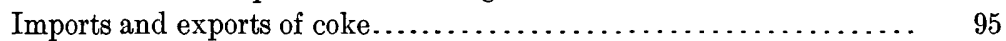

Consumption of raw materials.......................... 96

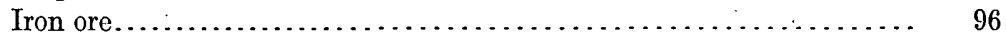

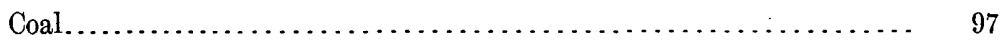

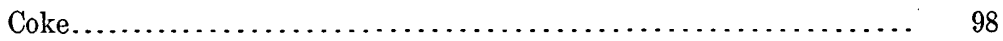

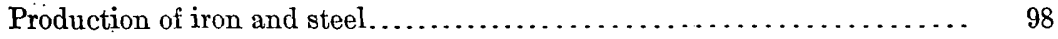

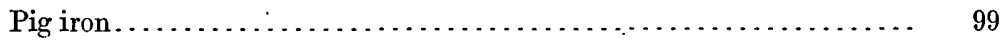

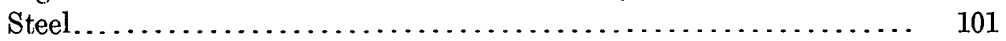

Puddled and forge iron. . . . . . 103

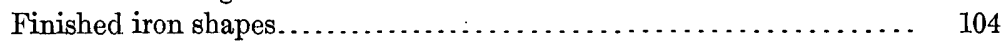

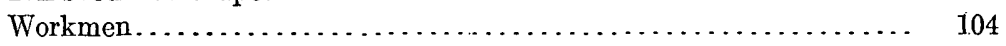

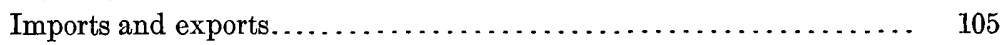

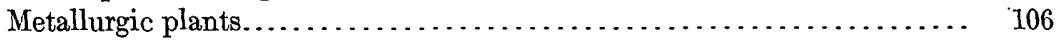

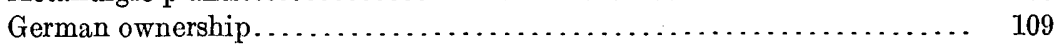

Mines and plants.......................................... 111

Principal works consulted, compiled by Harold $\mathrm{F}$. Crooks. . . . . . . . . . . 125

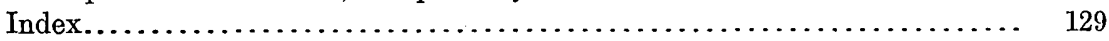




\section{TABLES.}

Area and ore reserves of Lorraine iron field, 1913.

Coke produced in France, 1913, by Departments.

Prices of coal and furnace coke in coal fields tributary to Lorraine iron districts, 1909-1914

Coking coal in fields tributary to Lorraine iron field and estimate of production in 1924

Corporate ownership of iron and steel plants and iron lands in Lorraine, Sarre district, Luxemburg, and Belgium, 1913.

German corporations controlling iron and steel industry of Lorraine Annexée, Sarre district, and Luxemburg.

Estimated value of German interests in iron and steel industry of Lorraine, Sarre district, Luxemburg, and Belgium, $1913 \ldots \ldots \ldots \ldots \ldots \ldots \ldots \ldots . . . \ldots \ldots$

Estimated value of German interests in Sarre coal lands and coal mines, 1913. .

Estimate of gross value and profits on iron ore, pig iron, and raw steel produced in districts using principally Lorraine iron ore, 1913.

Men employed in iron mining and metallurgic industries of Lorraine, Luxem-

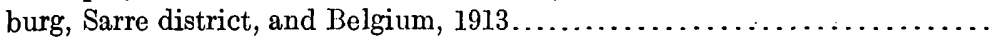

Lorraine iron ore produced and consumed, $1913 \ldots \ldots \ldots \ldots \ldots \ldots \ldots \ldots \ldots$.

Estimated capacity for 1919 of metallurgic plants which before the war smelted Lorraine iron ores.

Estimate of minimum capacity of iron and steel plants dependent on Lorraine ore, 1924

Estimate of consumption of Lorraine ore after iron and steel industry is reestablished and enlarged.

Areas, iron-ore reserves, and production of French Lorraine iron field........ Iron ore produced in French Lorraine, 1904-1913..................... Approximate distribution of iron ores from French Lorraine, 1904-1913. ....... Iron ore smelted in French Lorraine, 1904-1913, by sources . . . . . . . . . . . . . Pig iron and steel produced in French Lorraine, 1904-1913................ Coke and coal consumed by iron and steel works of French Lorraine, 1904-1913. . Coke and coal consumed in French Lorraine, 1912-13, by sources... . . . . . . .

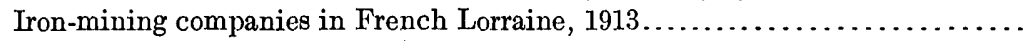

Summary of concessions of iron lands in French Lorraine, 1913 . . . . . . . . . .

French and Belgian ownership of iron lands in French Lorraine, 1913 . . . . . . .

German ownership of iron lands in French Lorraine, $1913 . . . . . . . . . . . .$.

Iron and steel companies in French Lorraine, 1913...................

Summary of iron and steel plants in French Lorraine, $1913 \ldots . . . . . . . . . .$.

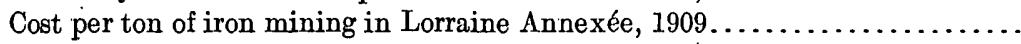

Iron ore produced in Lorraine Annexée and consumed in different countries, 1904-1913

Iron ore consumed and pig iron and steel produced in Lorraine Annexée, 1904-1913.

Capitalization of companies operating blast furnaces, steel plants, and mines in Lorraine Annexée, $1 \dot{9} 13$.

Ownership and production of iron lands and mines, blast furnaces, and steel

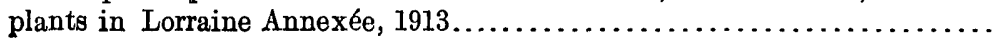


Page.

Estimated value of iron lands, mines, furnaces, and steel plants in Lorraine

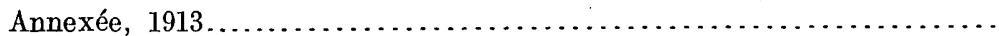

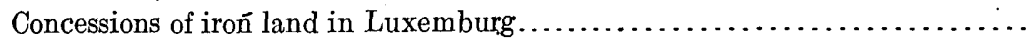
Sale price of iron-ore conceśsions in Luxemburg, 1904-1913................. Approximate tonnage of iron ore controlled by furnace companies in Luxem-

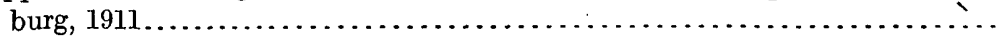

Approximate tonnage of iron ore acquired by furnace companies in Luxemburg, 1913

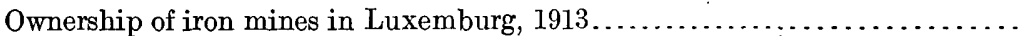

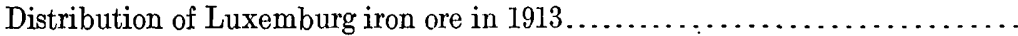

Iron ore produced in Luxemburg and consumed in different countries, 1904-1913

Distribution of cost of mining iron ore in Luxemburg, $1911 . . . \ldots \ldots \ldots . . . . .$.

Iron ore consumed and pig iron and steel produced in Luxemburg, 1904-1913. .

Ownership and production of companies operating iron mines, blast furnaces,

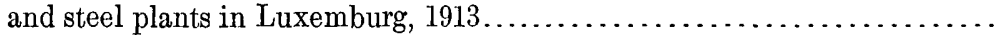

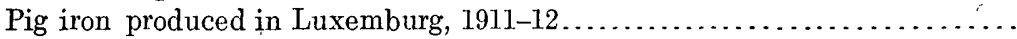

Approximate distribution of pig iron smelted in Luxemburg, $1913 . \ldots \ldots \ldots .$.

Iron products manufactured by foundries in Luxemburg, 1911-12 .........

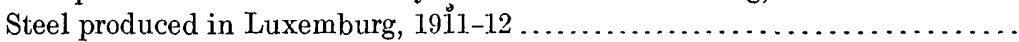

Luxemburg iron-ore reserves owned by different companies, $1913 . \ldots \ldots \ldots \ldots$.

Capitalization of companies operating iron-ore mines, blast furnaces, and steel plants in Luxemburg, 1913 . . .

Estimated profits on German iron and steel plants in Luxemburg, 1913......

Estimated value of German interests in Luxemburg iron and steel industry....

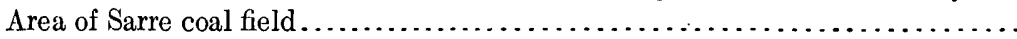

Coal land in Government and private ownership in Sarre field, $1913 \ldots \ldots \ldots$.

Coal and coke produced and consumed in the metallurgic industries of the

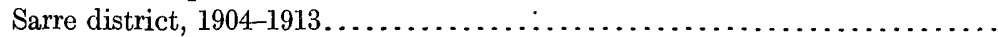

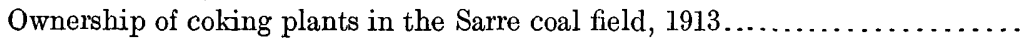

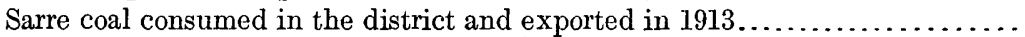

Pig iron and steel produced in the Sarre district, 1904-1913 ................

Ownership and production of blast furnaces and steel plants in the Sarre district, 1913.

Estimated value of German interests in Sarre coal lands and coal mines, 1913..

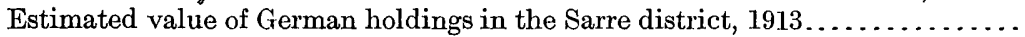

Belgian blast furnaces and steel plants in operation July $1,1914 \ldots \ldots \ldots \ldots \ldots$

Raw materials consumed in Belgian iron and steel industry, $1913 \ldots \ldots \ldots \ldots$.

Output of pig iron, crude steel, and finished iron and steel products in Belgium, 1913.

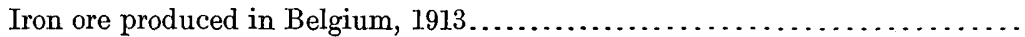

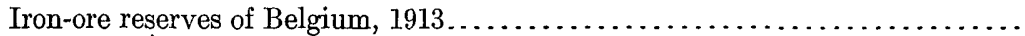

Iron ore smelted in Belgium, 1904-1913, by sources....................

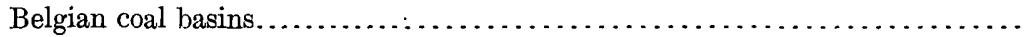

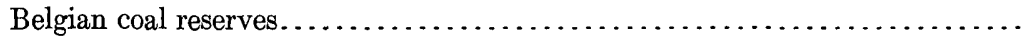

Statistics of Belgian coal industry, 1904-1913........................

Average annual coal production per mine and per workman in Belgium, 1913..

Cost, average value, and profit per ton of coal mined in Belgium, 1906-1910, 1912 , and 1913

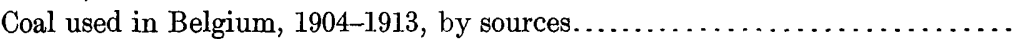

Excess of Belgian coal exports or imports, 1904-1913...................

Statistics of coke production in Belgium, by districts, $1913 \ldots \ldots \ldots \ldots \ldots \ldots$.

Statistics of coke production in Belgium, 1904-1913.....................

Coke produced, imported, and consumed in Belgium, 1904-1913 ............. 
Iron ore, etc., consumed in Belgian blast furnaces, 1904-1913 ............ 97

Coal consumed in Belgian iron and steel industry, 1904-1913.. ........... 97

Coke consumed in Belgian iron and steel industry, 1904-1913............ 98

Coal and coke used in Belgium in 1913 by consumers.................. 98

Statistics of pig-iron production in Belgium, 19904-1913................. 99

Pig iron imported, exported, and consumed in Belgium, 1912-13 . ......... 100

Metallurgic and mechanical equipment of Belgian steel companies, 1904 and 1913

Crude steel produced in Belgium, 1904-1913 .........................

Semifinished steel produced in Belgium, 1904-1913.................... 102

Finished steel products manufactured in Belgium, 1913................ 102

Finished steel products manufactured in Belgium, 1904-1913 ............ 103

Equipment of Belgian companies manufacturing finished iron and steel pro-

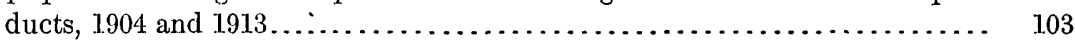

Puddled and forge iron produced in Belgium, 1904-1913 ............... 103

Finished iron shapes produced in Belgium, 1904-1913.................. 104

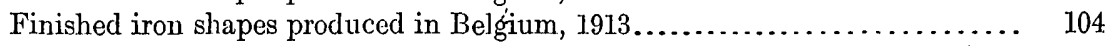

Belgian imports and exports of iron and steel products, $1913 \ldots \ldots \ldots \ldots \ldots \ldots . . \ldots 5$

Belgian iron and steel products exported in 1913, by countries.......... 115

German owned or controlled iron and steel companies in Belgium, 1913 ...... 110

Belgian iron mines........................................ 111

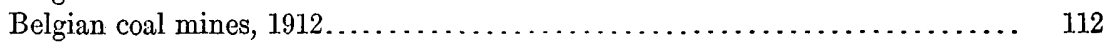

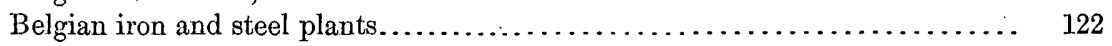




\section{ILLUSTRATIONS.}

iron district and tributary In pocket.

II. Sketch map showing geographic relations of Lorraine iron district and tributary coal fields.............................. $\quad 12$

FrguRE 1. Steel production of Europe, 1884-1913................... 14

2. Consumption and production of iron ore in German Empire,

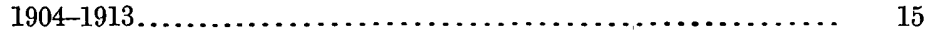

3. Iron content of known iron-ore reserves in Europe, France, and

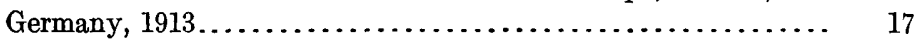

4. National ownership of cual reserves of Europe in 1913 and cf coal reserves tributary to Lorraine iron district in $1919 \ldots \ldots \ldots \ldots .21$

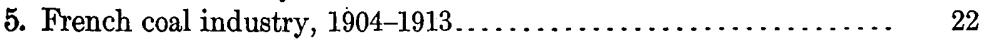

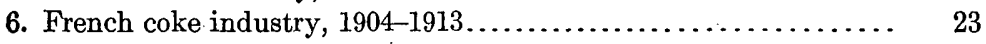

7. Sources of coke used in smelting and refining Lorraine iron ore in

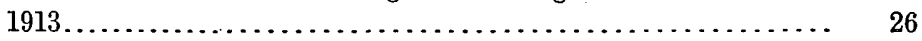

8. Production, consumption, and exports of iron ore in Lorraine Annexée..................................... 53

9. Consumption and imports of iron ore in Belgium, 1901-1913 ..... 85

10. Production, consumption, and imports of coal in Belgium, 1904-

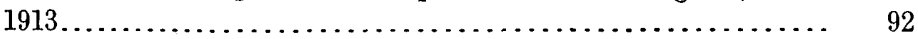

11. Production, consumption, and imports of coke in Belgium, 1904-

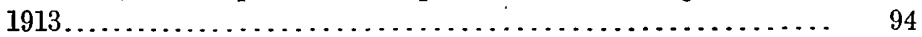

12. Production of pig iron in Belgium, 1904-1913............... 100 


\title{
THE IRON AND ASSOCIATED INDUSTRIES OF LORRAINE, THE S.ARRE DISTRICT, LUXEMBURG, AND BELGIUM.
}

\author{
By Alfred H. Brooks and Morris F. La Crolx.
}

PREFACE.

By Alfred H. Brooks.

Among the economic changes caused by the war none are of greater importance than those that affect the iron and steel industry. The restoration of Lorraine Annexée ${ }^{1}$ gives France not only complete control of 48 per cent ${ }^{2}$ of the European iron reserves but under preseni conditions gives her virtually a monopoly of the ironmining industry of continental Europe. The output of the French coal fields, however, even with France in control of the Sarre, will be far below her requirements, and she must continue to draw on other countries for a corsiderable part of her coal and coke.

Germany, on the other hand, with the loss of Lorraine iron ore, can not continue to be a power in the metallurgic industry unless she draws heavily on foreign countries for iron. She will, however, still own in her Westphalian fields the largest reserve of coking coal in continental Europe. France will therefore control the iron of continental Europe and Germany to a large extent will control the coking coal.

Belgium has considerable reserves of coking coal, but the product of her mines will always find a strong competitor in an open European market with that of Westphalia. If Westphalian coking coal, which can be sold at a lower price than that of other countries, is shut out of France and Belgium the cost of producing iron and steel there will be increased. This would mean a higher price to the domestic consumer and would make it more difficult for France and Belgium to compete in the steel market of the world.

The iron mines of French Lorraine have been relatively little damaged, and given the labor could soon be restored to their pre-war productive capacity. A considerable number of the French and

1 The part of Lorraine that was taken from France by the Treaty of Frankfort (1871) and restored by the Treaty of Versailles (1919) has been miscalled German Lorraine and by the Germans Lothringen. As this paper treats chiefly of the pre-war conditions, this district will be referred to by its French name Lorraine Annexée. It was formerly a part of the Department of the Moselle.

2 The figures on iron-ore reserves used in this volume represent known ore and are taken from "Iron-ore resources of Europe," by Max Roesler (U. S. Geol. Survey Bull. 706, in preparation). 
Belgian metallurgic plants that used Lorraine ore have been destroyed and it may take five years to restore them to their pre-war capacities. The inclusion in France of the iron and steel plants of Lorraine Annexée and the control of the Sarre district will afford but little relief, as these plants will continue to be supplied from the mines on the German side of the pre-war frontier. Therefore, unless the ore is sent to Westphalian and Rheinland furnaces the mines in French Lorraine can not be worked to their full capacities during the reconstruction period, a fact that would be very regrettable, for their product would give a quick asset to impoverished France. Without this outlet the French iron mines can find a market for only about half the ore they can produce. Furthermore, it is by no means certain that even after restoration the French and Belgian plants can consume all the iron produced by the Lorraine mines. Therefore, however desirable it may be to limit Germany's output of iron and steel, any such limitation will certainly, during the period of reconstruction and probably after it, curtail the output of the iron mines of French Lorraine.

The rebuilding of the French and Belgian metallurgic plants will make it possible to install in them the most modern equipment and will thus give them some advantage over competitors that use pre-war plants. On the other hand, during this period of construction the French and Belgian steel and iron products will in an open market be more or less at the mercy of the undamaged, established industries of other countries. A whip hand can be held over Germany by refusing her the iron ore and not using her coal, but the employment of this resort, as has already been shown, will be to the disadvantage of the French mines and will increase the cost of iron and steel products in both Frances and Belgium.

The French ownership of iron ore, the coking coal reserves of Belgium, and, especially, the geographic position of Belgium, which makes it the natural seaboard outlet for the Lorraine field, will give France and Belgium advantages in the world market for their iron and steel products. These economic advantages would be further improved by a competitive use of Westphalian coking coal, which is so favorably located for cheap transportation into both countries.

To arrive at an understanding of these problems it was necessary to make an investigation of the pre-war conditions of the industry. The results are here submitted in several chapters dealing with the iron and steel industries of the districts that consumed the greater part of the Lorraine iron ore during the pre-war decade. The first chapter is an attempt to apply the results to the above-cited problems by forecasting the future of an industry based on Lorraine iron ore.

In addition to the facts regarding, the industry itself information on ownership has been collected, especially with reference to the con- 
trol by German capital. This increased the work greatly, for it necessitated a search for data relating to more than 200 corporations operating in France, Germany, Luxemburg, and Belgium.

This report in its original form was prepared at Paris for the use of the American Commission to Negotiate Peace. Its compilation was due to suggestions made by Mr. Charles P. Perrin and Dr. C. K. Leith, and it was brought to completion at the request of Dr. A. A. Young, economist of the Peace Commission. The data were compiled and the report was prepared under the direction of Brig. Gen. Charles H. McKinstry, then chief of the War Damage Board of the Peace Commission, to whom the writer is indebted both for fullhanded support of the project and for all needed office facilities.

The purpose of the original report was to lay before the commission certain facts relating to the pre-war use of Lorraine iron ore and thereby to forecast the probable future of the metallurgic industry in Lorraine as modified by the new national control of certain districts. The signing of the peace treaty has put into effect the changes in national control which were only under discussion when the report was submitted. Other questions relating to international exchange of raw material are still unsettled. The original report was in effect an argument for the adoption of certain policies with reference to the iron and coal industries of central Europe. In the revision of the report some attempt has been made to modify statements to accord with the new conditions created by the signing of the peace treaty, but in general the report must remain as originally prepared. For the reasons stated the reader will find that certain parts of the report are presented as arguments rather than as expositions, a form that would be more appropriate for this publication.

Certain other features inherent in the original draft can not now be changed in the time available for its revision. The peace commission desired to obtain as complete a statement ${ }^{3}$ as possible regarding corporate and especially German pre-war ownership of the iron and steel industries here discussed. This was therefore made an important feature of the report, and it remains as originally presented, though in view of changes of ownership, due to the new economic conditions, it now has or soon will have little more than historic interest. It is unfortunate, also, that the report as originally prepared did not include footnote references to the sources of the facts presented. To insert them now would be too great a task, but all the works consulted are listed at the end of this volume.

\footnotetext{
3 There are fairly complete statements on capitalization, holdings, etc., of Belgian corporations in " $\mathrm{La}$ 1 Recueil financier, 1918," Brussels, 1918; and of German corporations in "Handbuch der deutschen AktienGesellschaften," editions of 1917-18 and 1918-19, Berlin. The published statements in regard to French corporations are very incomplete. The best are contained in the "Annuaire du Comité des forges de France, 1914 and 1915," and "Annuaire du Comité général des houillères de France, 1914." Both were published in Paris.
} 
In general, the statistics of production here presented are derived from official publications that are both accurate and complete. On the other hand, complete data on the movements and places of consumption of some iron ore, iron and steel products, and coal are lacking, and this part of the statistical data was therefore supplemented by the best estimates available. The possible errors in these estimates are, however, not large enough to invalidate the conclusions presented and therefore will not affect the general argument. It should be added that the published statistics for Belgium are more complete than those for any other countries considered.

The least accurate of the statistics here presented are those relating to net profits, gross value of products, and value of mineral lands and mining and metallurgic plants. In this field the published data are very incomplete, especially in regard to the French industry. There are no complete French official figures on unit values of manufactured iron and steel products. In the absence of exact data certain assumptions had to be made, but these assumptions are believed to be so nearly true that they do not invalidate the general accuracy of the conclusions reached. In any event, an attempt has been made to make the tables presenting profits and values in the different districts consistent among themselves by using comparable unit values. Therefore these tables, though they may contain errors, are yet relatively fairly accurate.

In addition to preparing the parts of this report with which he is credited, Maj. Morris F. La Croix, Engineers, has contributed many valuable suggestions that are embodied in other parts of the volume. Lieut. Harold F. Crooks, Engineers, rendered invaluable aid throughout the investigations. It was his special task to compile the data on which many of the statistical tables are based. The magnitude of this task is shown by the list of works consulted. ' (See pp. 125-127.)

While he was serving in the Engineer Corps, United States Army, the writer was fortunate in becoming familiar with much of the region whose iron industry is here under discussion. None of this field work was, however, done with a view to preparing this report. Moreover, the journeys to northern and northeastern France were made in part during the war, when the conditions for observations were by no means favorable. The office studies were made at Paris late in the winter of 1919 and occupied the time of three Engineer officers for two months. This investigation was made possible only by facilities offered by a number of Paris libraries and institutions. Among these, special acknowledgment for the loan of books should be made to the Ecole des mines, the Comité général des houillères de France, and the Comite des forges de France. The writer is also indebted to Dr. Alexandre Delmer, of Brussels, for information about the iron and steel plants of Belgium. 


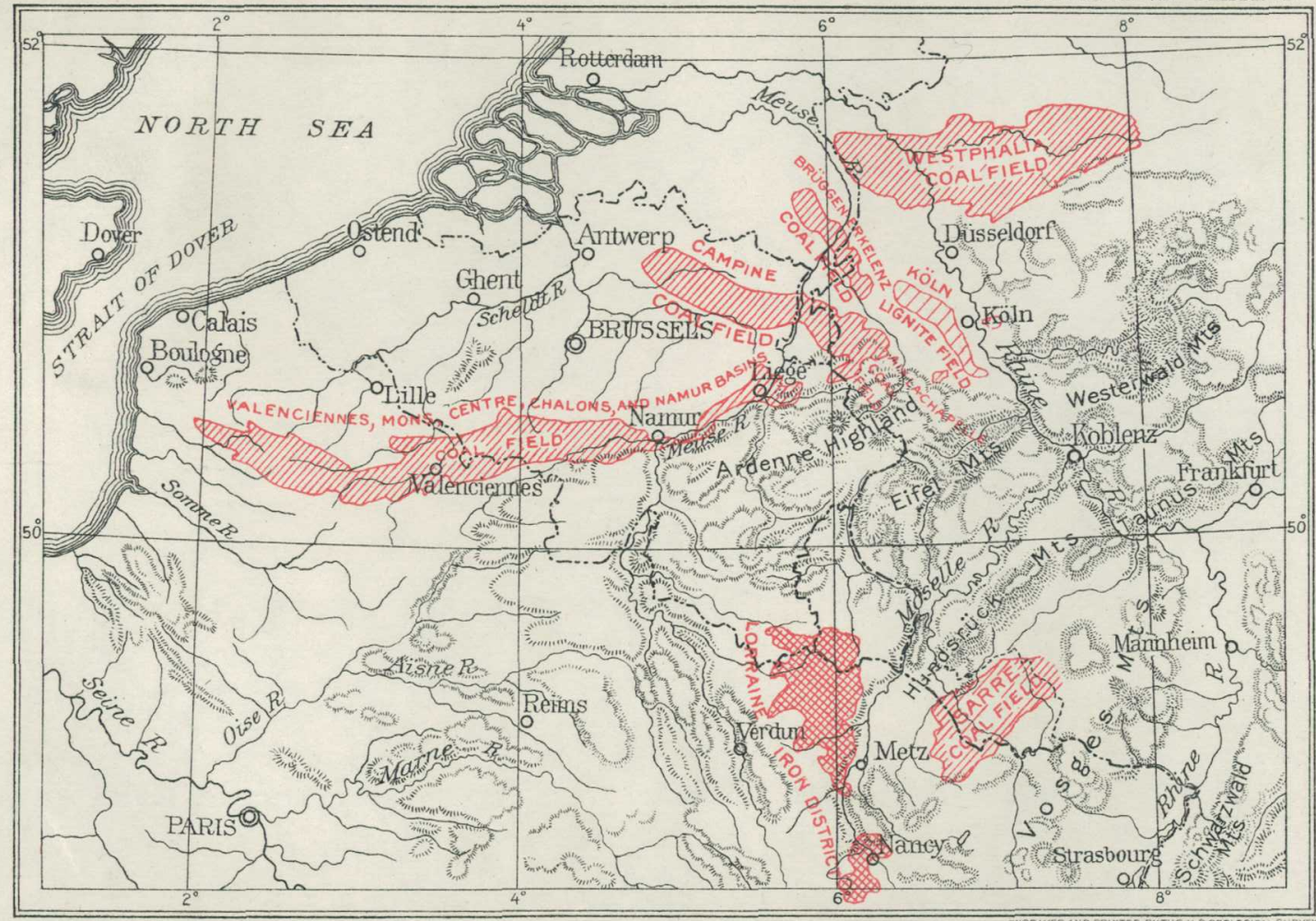

SKETCH MAP SHOWING RELATIONS OF LORRAINE IRON-ORE DISTRICT AND TRIBUTARY COAL FIELDS $\circ$ 100 150 MILES

두 $50 \quad 100 \quad 150$ KILOMETERS 
Max Roesler, of the United States Geological Survey, has made an exhaustive study of the literature relating to the iron ores of Europe, but his results were not available when the original of this report was prepared. This report, which deals primarily with the utilization of the Lorraine iron ore, is therefore supplementary to such parts of Mr. Roesler's report as deal with this deposit. Mr. Roesler's report ${ }^{4}$ has been used in the revision of this manuscript with reference to iron-ore reserves.

The war has shown that the American people should have full knowledge of European industries, and especially of the iron and steel industry of Lorraine, which has been and will be the strongest competitor with our export trade in iron and steel products. This condition is believed to be a full justification for making available to American readers the facts contained in this volume.

\section{THE PAST AND FUTURE USE OF LORRAINE IRON ORE.}

By Alered H. Brooks.

\section{INTRODUCTION.}

The enormous development of the iron' and steel industries of continental Europe during the last two decades (see fig. 1) has in large measure been the result of the best economic use of the iron ore from Lorraine and of the coking coal from the tributary fields. (See Pl. II.) Though the ownership of the iron and coal was distributed among four countries (see map, Pl. I, in pocket), trade restrictions did not reduce very much the free movement of the raw material. As a consequence large iron and steel industries grew up at localities determined by geographic conditions rather than by political boundaries.

Evidence of the magnitude of this pre-war industry is found in the value of the iron lands and of the metallurgic plants using Lorraine ore in the districts here described. The total value of these in 1913 is estimated to have been 4,150,000,000 francs. To this should be added the value, estimated to have been even greater, of such of the metallurgic plants of northern and central France, the Rheinland, and Westphalia as use the Lorraine ores. The total value of the iron mines and lands of Lorraine and of the furnaces and steel plants of France, Luxemburg, Belgium, and Germany that used Lorraine iron ore in 1913 was probably about 10,000,000,000 francs.

The gross value of the iron ore and iron and steel products of the districts here described in 1913 was about 1,982,850,000 francs, and the profits were about $246,000,000$ francs. About 150,000 men were employed in these industries. The gross value and profits on the manufacture of iron and steel made from Lorraine iron ore and pig

1 Roesler, Max, The iron-ore resources of Europe: U. S. Geol. Survey Bull. 706 (in press). 
iron shipped into other districts than those here considered has not been determined. Though the above figures on values and profits are only roughly approximate, they indicate the magnitude of the mining and metallurgic operations that were based on the iron deposits of Lorraine.

More accurate evidence of the magnitude of the Lorraine iron industry is found in the percentages it contributes to the total iron. output of Europe, France, and Germany. In 1913 Europe consumed $109,030,000$ tons $^{5}$ of iron ore, of which $48,093,000$ tons came

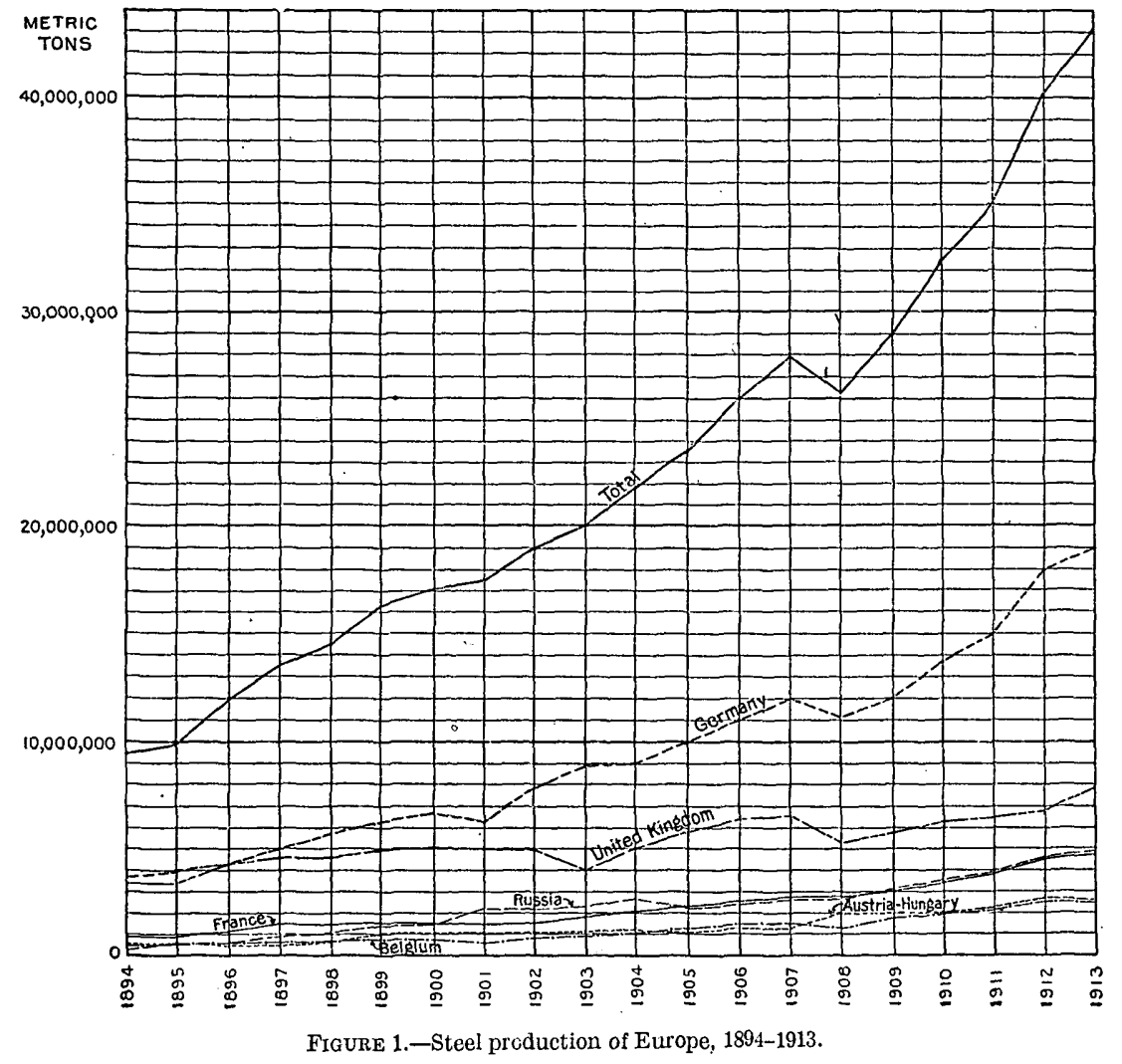

from the Lorraine field, including Luxemburg. The Lorraine iron ore is of much lower grade than the average of other European iron districts, ${ }^{6}$ and the above ratios of tonnage of ore consumed therefore somewhat exaggerate the importance of the Lorraine output. If only the iron content of the ore is considered the Lorraine fields in 1913 furnished 34 per cent of the total iron consumed in Europe, and if the consumption of the British Isles is deducted, Europe in 1913 drew 40 per cent of its metallic iron from the Lorraine field.

${ }^{5}$ All weights are here given in metric tons. A metric ton equals 1.1 short tons.

${ }^{6}$ In 1913 the average iron content of all the ore consumed in Europe was about 41 per cent; that of Lorraine ore, 32 per cent; that of European iron ore without Lorraine, 49 per cent. 
In 1913 France consumed 13,262,000 tons of iron ore, of which $12,511,000$ tons (including 376,000 tons from Luxemburg) came from the Lorraine field. On reducing this to metallic content of iron we find that 95 per cent of French iron in 1913 was produced from Lorraine ore.

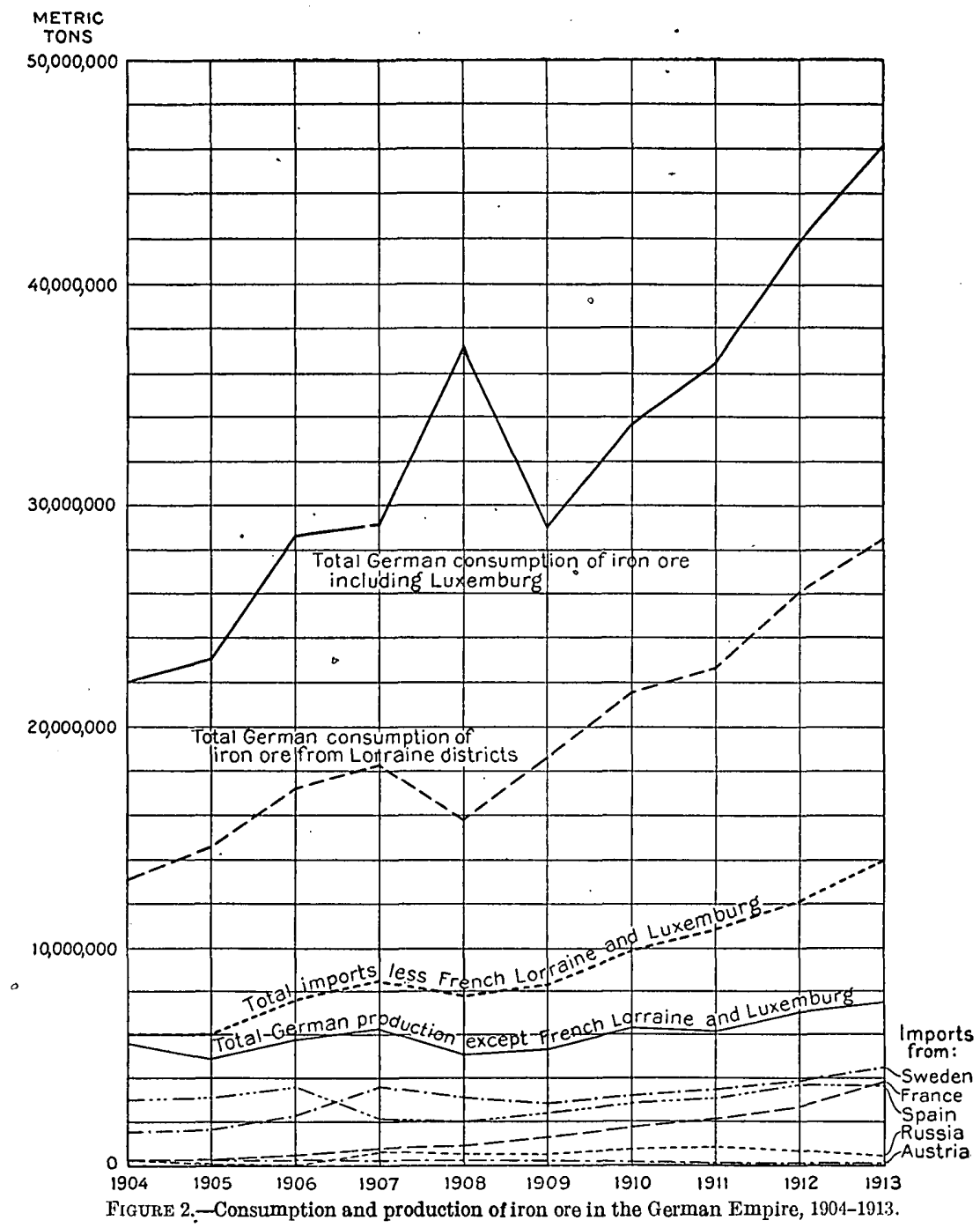

Germany's dependence on Lorraine iron ore (see Pl. II) during the enormous expansion of her iron and steel industry in the pre-war decade is illustrated by the accompanying diagram (fig. 2). In 1913 63 per cent of the iron ore she consumed and about 50 per cent of the metallic iron came from the Lorraine fields. ${ }^{6}$ a The diagram shows that Germany has in the past drawn heavily on Spain and Sweden

6a In $191328,608,000$ tons of iron ore was mined in the German Empire, of which 21,000,000 tons came from I.orraine Annexée. 
for iron ores, but that during the last few years there has been no marked increase in the imports from those countries. Spain's reserves of the highest grades of iron ore, which have found a marizet in Germany, are indeed being depleted, though she still has large reserves of ore having a lesser iron content. Sweden has during the last decade enacted laws ${ }^{7}$ placing certain restrictions on exports of iron ore.

It is for these reasons that Germany's iron masters before the war became alarmed as to a future supply of iron for their rapidly growing industry. To provide for the future, German iron and steel companies then began buying large tracts of iron land in French Lorraine. Before the outbreak of the war the Germans had already secured control of 10 to 15 per cent of the entire field. It is probable that German iron masters 'viewed with equanimity the outbreak of the war, which they were assured would give them control of the great Lorraine iron field.

The pre-war distribution of the iron reserves of Europe, France, and Germany is illustrated in figure 3. At that time France owned 33 per cent of Europe's iron reserves and Germany 22 per cent. The German plan to annex French Lorraine would have given Germany control of practically 50 per cent of Europe's known iron resources. As it is, the Treaty of Versailles has left Germany with only 7 per cent of Europe's iron reserves, while France owns 48 per cent. Moreover, the deposits of iron ore in the German Republic are widely scattered, and some of them are not favorably located for economic development. Therefore any large production of iron or steel in Germany must be based on imported ores. Her metallurgic industry would be doomed were it not for the fact that.Germany owns in her Westphalian field the largest reserve of coking coal on the European continent. It will be shown that this coal is necessary to assure an economic utilization of France's Lorraine ores.

\section{LORRAINE IRON DEPOSITS.}

GENERAL FEATURES.

Except for some small outliers the great iron deposits of Lorraine occur in a belt extending northward from about the latitude of Metz, along the pre-war frontier between France and Germany. (See Pl. I, in pocket.) This iron-bearing zone reaches into both countries, traverses the southern apex of Luxemburg, and ends just within the Belgian frontier. It has a length of 60 kilometers and is from 10 to 30 kilometers wide. To the south is the Nancy iron district, lying entirely within what was formerly French Lorraine and forming an extensive outlier of the main Lorraine iron field. (See Pl. I.)

7 Die schwedische Eisenerzfrage: Stahl und Eisen, vol. 27, pp. 533-534, 1907. 


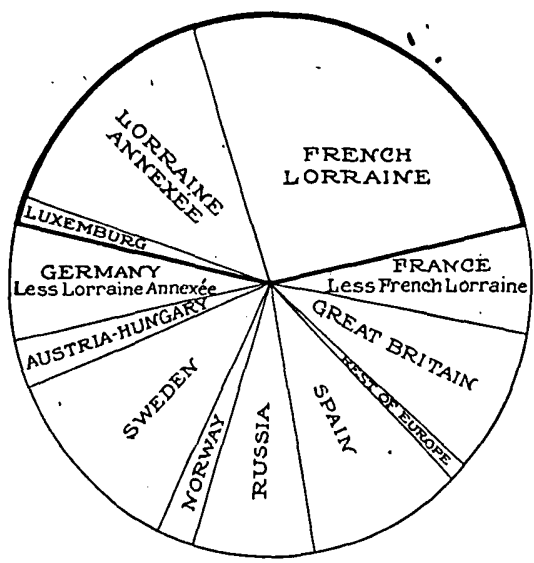

EUROPE.

\begin{tabular}{|c|c|c|}
\hline - & $\begin{array}{l}\text { Tons of iron } \\
\text { (Fe). }\end{array}$ & $\begin{array}{l}\text { Per cent } \\
\text { of total. }\end{array}$ \\
\hline 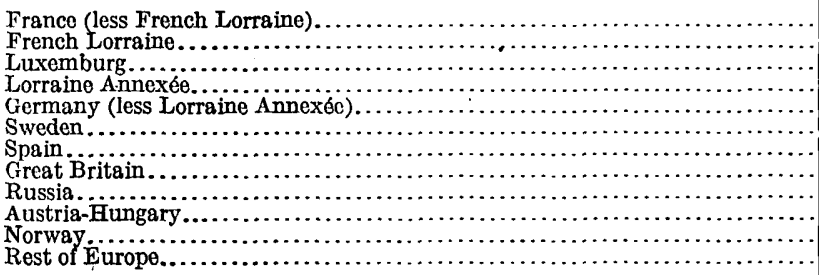 & $\begin{array}{r}242,000,000 \\
990,000,000 \\
60,000,000 \\
558,000,000 \\
260,000,000 \\
443,000,000 \\
353,000,000 \\
318,000,000 \\
284,000,000 \\
111,000,000 \\
86,000,000 \\
31,000,000\end{array}$ & $\begin{array}{r}6.6 \\
26.5 \\
1.6 \\
15.0 \\
7.0 \\
11.9 \\
9.2 \\
8.5 \\
7.6 \\
3.0 \\
2.3 \\
.8\end{array}$ \\
\hline Total European reserves. & $3,736,000,000$ & 100.0 \\
\hline
\end{tabular}

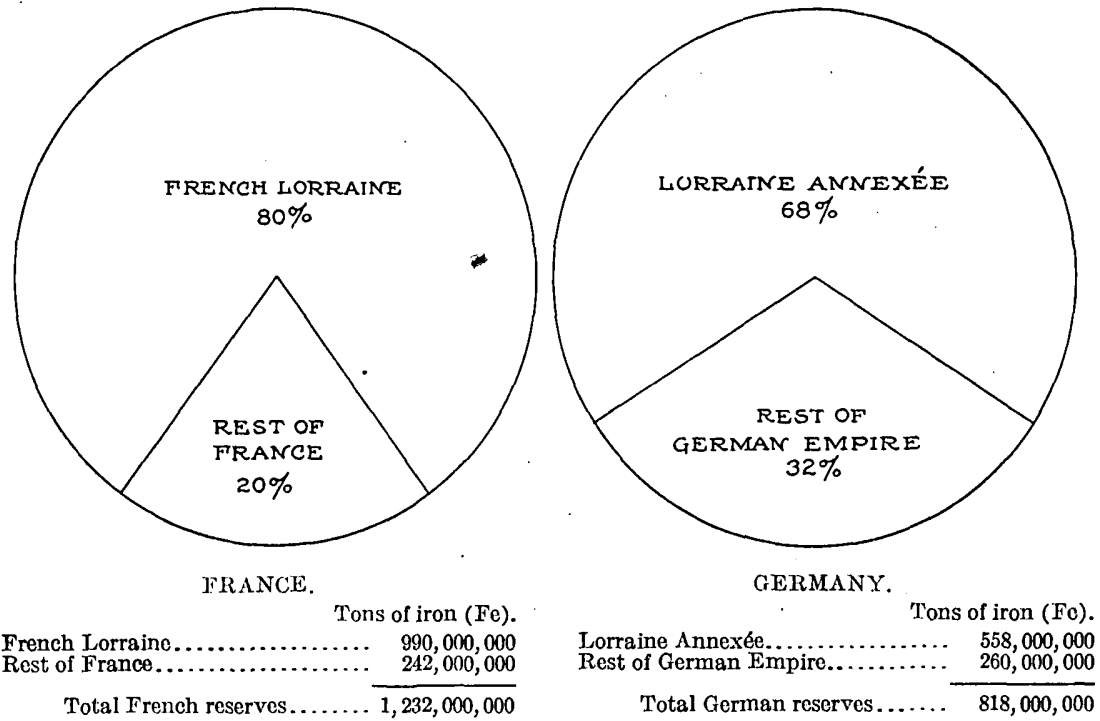

Total French reserves...... $1,232,000,000$

Total German reserves...... $818,000,000$

FigURE 3.-Iron content ( $\mathrm{Fe}$ ) of known iron-ore reserves in Europe, France, and Germany, 1913, $187234^{\circ}-20-$ Bull. $703-2$ 
The Jurassic sediments in which the beds of iron ore occur crop out along the eastern margin of the belt and dip for the most part gently to the west. This simple monoclinal structure is modified by some upwarps and faults which lie at right angles to the general trend of the belt and which have divided the field into a number of ill-defined basins. In general the ore beds occur as outcrops or at shallow depths in the eastern part of the field and at considerable depths in its western part. The western boundary of the field has not been everywhere definitely determined, and it may extend beyond the limits shown on the map (Pl. I).

Though the Lorraine iron deposits were among the first in Europe to be utilized, their modern industrial importance dates from the discovery in 1880 of a method of economic use of their high-phosphorus ores. At the time of the Treaty of Frankfort the great potential value of the Lorraine iron field had not been realized. Moreover, the bedded character of the deposits was not known, and the commercial ore bodies were believed to be limited to the outcrops. Bismarck therefore took only the zone along the outcrops where ore had actually been mined, and, as it subsiequently proved, by ignorance of the geologic conditions left to France much the larger part of the reserves. No doubt the hope of rectifying this matter from the German point of view was one of the most important contributory causes of the war.

The Lorraine ore deposits are by far the most valuable in Europe, because (1) they contain the largest reserves occurring in one field (see Pl. II); (2) they are readily accessible and within easy communication of large coal fields; (3) they are of suitable composition for the basic process; and (4) they are mined at a comparatively low cost.

\section{RESERVES.}

The total reserves of iron ore in the Lorraine field are estimated to be $5,000,000,000$ tons. This estimate, because of the comparative regularity of the deposits, is probably more nearly accurate than those made for most iron-ore districts. The distribution of the iron lands and reserves by countries and districts is as follows:

Area and ore reserves of Lorraine iron field, 1913.

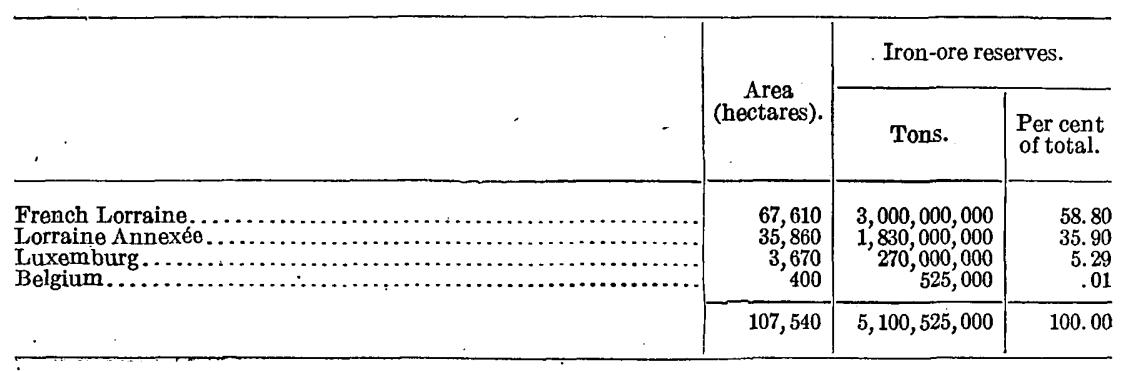


Any forecast of the time of exhaustion at the increasing rate of production during the pre-war decade is liable to be seriously in error. It is certain, however, that these deposits will not be exhausted within a century. Though the iron content of the Lorraine deposits is low compared with that of other iron ores of Europe they contain 43 per cent of the total metallic iron reserves of Europe.

\section{GEOGRAPHIC RELATIONS."}

The position of the Lorraine field along the drainage basins of Meuse and Moselle rivers renders them readily accessible to these two large tributaries of the Rhine. (See Pl. II.) This locátion gives railroad connections by easy grades both with the Rhine Valley and with the lowlands of Belgium, which, in turn, has an elaborate canal system connecting with tidewater ports. (See Pl. I, in pocket.) Both the Rhine-Marne and the Meuse canals, which give outlets to the east and north, are not far distant but have been little used for ore. Prior to the war less than 5 per cent of the ore shipped to the Rhine Valley was water-borne. The return cargo of coking coal from the Westphalian fields has, however, been a great factor in the Lorraine iron industry. The long-debated project of a canal down the Moselle, the building of which would afford no serious difficulties, would give still better transportation to the Rhine Valley.

The coal of the Sarre district lies close to the iron of Lorraine. That of Belgium and northern France has been extensively used in the Lorraine field and involves a railroad haul of about 150 kilometers. It will be shown below that the high-grade coal of Westphalia, which is readily accessible by rail and canal, has been of the highest importance in the development of the Lorraine ores.

\section{COMPOSITION OF ORES.}

The iron content of the Lorraine ore ranges from 24 to 41 per cent; the average of the ore mined in 1913 was about 33 per cent. The iron content of these deposits is low compared with that of the deposits in other European districts, which runs from 50 to 60 per cent. It has been the practice to smelt the low-grade Lorraine ore in the local furnaces and ship the better ore to the more distant places (Belgium, north and central France, and Westphalia). The iron content of the shipping ore is from 34 to 38 per cent. A valuable characteristic of the Lorraine iron deposits is that they contain both calcareous and siliceous ores, making it possible to obtain the proper mixture for blast furnaces.

Most important of all is the fairly constant phosphorus content (1.5 to 2 per cent) of the Lorraine ore. This makes it available for the basic process of reduction with the valuable by-product of 
slag fertilizer. In fact, the enormous development of the iron and steel industry using Lorraine ore is due entirely to the basic process of steel making, which was first employed in 1880 .

MINING COST.

The regularity of the Lorraine ores, which occur in beds, and other favorable conditions tend toward low mining costs. In 1913 the cost of mining was from 3 to 4 francs a ton. This is lower than the cost of mining in most other European iron fields.

\section{COKING COAL. ${ }^{8}$}

GENERAL DISTRIBUTION.

There are six coal fields within 250 kilometers of the Lorraine iron district (see Pls. I and II) which have a total known reserve of about $86,000,000,000$ tons of coal, of which at least 40 per cent is suitable for coking. Under present metallurgic practice it will require a total of about $2,500,000,000$ tons of coking coal to smelt the entire iron reserves of Lorraine. Therefore there is much more coking coal in these fields than is needed for all the known Lorraine ores. About 74 per cent of this coking coal is in the Westphalian field of Germany.

The distribution of the coal reserves of continental Europe is by no means favorable to France and Belgium, for much the larger part is east of the Rhine. Figure 4 illustrates the national ownership of European bituminous coal (including some anthracite but excluding subbituminous and lignite coals) in 1913. From this diagram it will be seen that the bulk of the coal belongs to Great Britain and Germany., These bituminous reserves contain all the coal which, ceven under improved coking practice, is likely to be used in metallurgic plants. Inasmuch as good coking coal is quite as necessary as iron ore for the development of iron and steel manufacture, the distribution of the fuel will favor the industries of Great Britain and Germany rather than those of France and Belgium. With the restoration of Lorraine Annexée to France she has more or less of a monopoly of the available iron ores of continental Europe, but as shown in figure 4 her ownership of the coal reserves, even including the Sarre field, will be small compared with that of Great Britain and Germany.

\section{FRENCH COAL FIELDS.}

The French coal fields have been extensively drawn upon to supply coke for the Lorraine ore. The coke is of good quality, but the reserves are not large, and before the war the quantity produced did

${ }^{8}$ In the revision of this section use has been made of an unpublished report by Eugene Stebinger, of the United States Geological Survey, entitled "Coal and coke in Europe." 
not suffice to smelt all the irón produced in French Lorraine. Most of the domestic coal used in smelting Lorraine ore-came from the Valenciennes field (see Pl. I), in the Department of Nord, the largest in France, which in 1913 produced 68 per cent of her coal. Here the coal-bearing rocks occur in a deep syncline, overturned and faulted on the south, with many minor folds and faults. These rocks continue eastward into Belgium, where they form the principal coal field of that country, and an extension into Germany is found in the Aix-la-Chapelle field. In the Department of Pas de Calais the deepest mining in 1913 was done at a depth of 1,000 meters, and the average depth of the hoisting shafts was about 350 meters. The

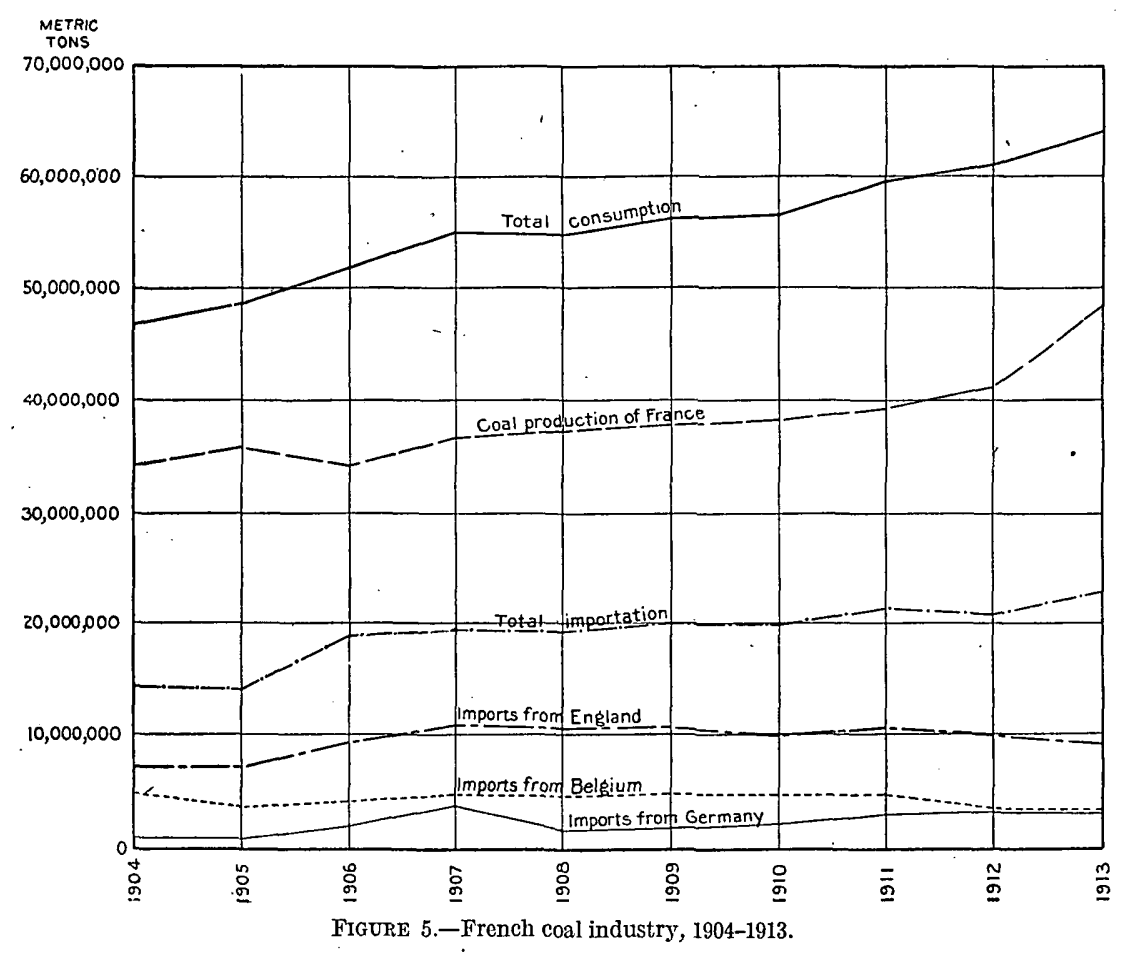

average price of coal f. o. b. at the mine in 1913 was 16.36 francs a ton. This was the lowest price for bituminous coal in France. Out of the 4,027,000 tons of metallurgic coke produced in France in 1913, $3,078,000$ tons was made from Valenciennes coal.

During the war much the larger part of the Valenciennes field was held by the enemy. Mining was active in that part of the field held by the British, however, even within the zone of shell fire. Indeed, for a while the French miners were actually recovering coal from deposits under the German trènches, entry being effected by a shaft some 2 miles distant. The Germans, discovering their operations, filled the underground works with gas and killed a number of the heroic miners. On evacuating the coal fields of France the Germans 
as a deliberate policy did as much damage to the mines as time permitted. As a result of this damage and the destruction incident to military operations, it will take some time, probably at least five years, to restore the Valenciennes field to its pre-war condition. ${ }^{8 a}$

In point of production the coal fields of the Department of the Loire (St. Etienne and smaller ones) are second in importance to France. The coke produced from coal mined in these fields amounts annually to only a few hundred thousand tons. A little coke is also produced from other fields in France, but it finds only a local market. The geographic location of all these fields makes it improbable that their coke will ever be extensively used in smelting Lorraine ore.

France is essentially an importer of coal and coke, for she is not able to meet her own requirements. In 1913 she produced 40,844,000 tons of coal ${ }^{9}$ (including lignite), of which $1,238,000$ tons was exported, and in the same year she imported 19,797,000 tons of coal.. This made the total consumption of France 58,403,000 tons, of which 33

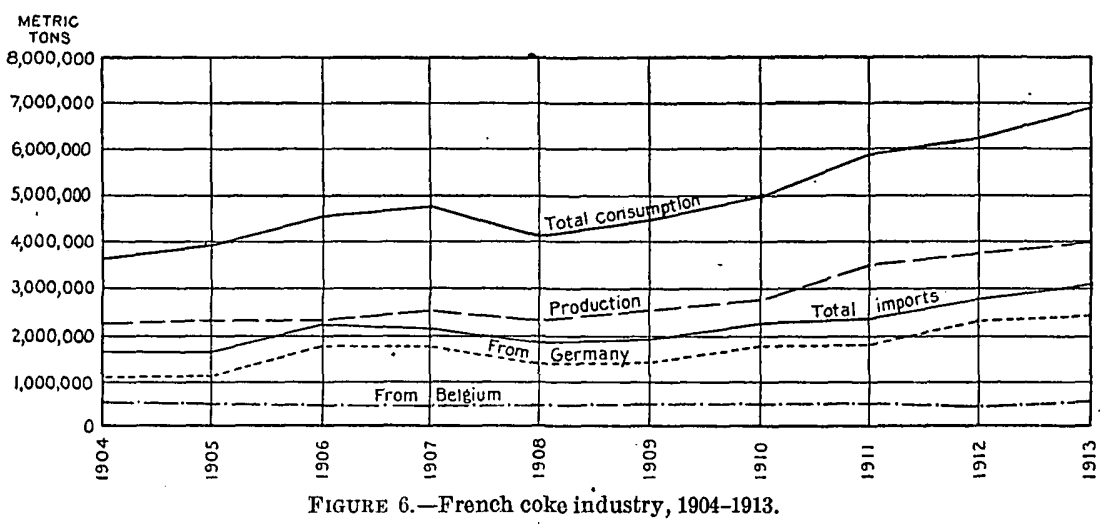

per cent was imported. Of the importations $11,257,000$ tons came from Great Britain, 3,491,000 tons from Germany, and 3,670,000 tons from Belgium. The problem of coal supply was one of the most difficult of the war. By desperate efforts Great Britain increased her shipments to $19,000,000$ tons in 1916 and to over 20,000,000 tons in 1917 and 1918. Great Britain and France were at the same time furnishing large quantities of coal to Italy. A shortage of coal in France is no new condition, as is shown by the accompanying diagram (fig. 5) illustrating the coal trade of the pre-war decade.

France is also a large importer of coke. In 1913 she consumed $7,097,000$ tons of coke, of which 41 per cent was imported. Of the imported coke 2,393,000 tons came from Germany and 547,000 from Belgium. The sources of the domestic coke are shown in the following table, and the coke trade during the pre-war decade is shown graphically in the diagram (fig. 6).

\footnotetext{
8a Rice, G. S., Destruction of French coal mines and plants and their rehabilitation: Franklin Inst. Jour., June, 1920, pp. 737-778.

${ }^{9}$ Statistique de l'industrie minérale, 1913, Paris, Ministère des travaux publics et des transports, 1917.
} 
Coke produced in France, 1913, by Departments.

\begin{tabular}{|c|c|c|c|}
\hline Pas-de-Calais. & $\begin{array}{c}\text { Tons. } \\
1,821,611\end{array}$ & Gard.$\ldots \ldots \ldots \ldots \ldots \ldots \ldots$ & $\begin{array}{c}\text { Tons. } \\
87,787\end{array}$ \\
\hline Nord. & $1,256,717$ & Isère. . . . . . . . . . . . . . & 60,010 \\
\hline Loire................... & 179,989 & Rhone................... & 22,500 \\
\hline Loire-Inférieure............. & 137,357 & Haute-Saône..... & 17,664 \\
\hline Tarn..................... & 125,984 & Cantal. & 11,230 \\
\hline Saône-et-Loire...... & 115,732 & Haute-Loire... & 1,341 \\
\hline Aveyron. & $\begin{array}{l}98,463 \\
91,039\end{array}$ & & 7,424 \\
\hline
\end{tabular}

Including that used for coke France consumed in 1913 a total of $64,834,000$ tons of coal, of which she produced only 60 per cent. The control of the Sarre field can not at best meet so great a deficit in production, for, as shown on page 77, not over 7,000,000 tons of the annual output from this field will be available for use in France as defined by her pre-war boundaries.

It has long been known that there is a western extension of the Sarre coal field on the French side of the pre-war boundary. This coal has been prospected by some 20 drill holes. In the Department of Meurthe-et-Moselle, adjacent to the Lorraine iron field, several coal beds have been found at depths ranging from 659 to 955 meters. The data collected indicate possible reserves of $630,000,000$ tons of coal of coking quality just where it is needed for reducing the Lorraine iron ore. For reasons difficult for a foreigner to understand no one has ever been granted a concession to mine this coal, though there have been a number of applicants. Meanwhile France has paid a heavy toll to Germany for Westphalian coking coal.

\section{WESTPHALIAN COAL FIELD. ${ }^{10}$}

The Westphalian coal field of Germany is in the lower Rhine Basin, chiefly east of the river. ${ }^{11}$ Being close to tidewater it is favorably situated for export trade. What is more important to this discussion, it is connected by railway as well as by rivers and canals with the centers of iron and steel manufacturing of Lorraine and of Belgium. This field contains 56 per cent of Germany's pre-war bituminous coal reserves. If the Sarre coal field is now regarded as French, the Westphalian field contains about 70 per cent of the coal reserves of the German Republic. (See fig. 3.)

The Westphalian coking coal is among the best in Europe. This fact, coupled with its geographic location with reference to the Lorraine iron ore on one hand and to tidewater on the other, has made Westphalia not only the greatest coal-producing center of Germany but also the scene of the most extensive manufacture of iron and steel. Here are located 103 of the 288 German blast furnaces operated in 1913 (not including Luxemburg), and Westphalia produced

${ }^{10}$ Called by the Germans the Rechtsrheinischer-Westphalischer Steinkohlen-Bezirk.

11 The extension of the field west of the Rhine is called the Crefeld Basin. 
in that year $8,220,000$ tons of the total German output of $17,760,000$ tons of pig iron. Of Germany's total of 159 steel plants in 1913, 91 were in the Rhine-Westphalia districts, and they produced $10,112,000$ tons of Germany's total of $17,617,000$ tons of steel. In 1913 some 4,500,000 tons of Lorraine iron ore was smelted in the Westphalian districts. In addition about $2,240,000$ tons of pig iron made from Lorraine ore was refined in Westphalia.

The Westphalian coal field measures 95 by 40 kilometers, and its strata are not greatly folded but are considerably faulted. All mining is done by shafts, which range from 40 to 740 meters in depth. In 1913 the Westphalian field produced 114,487,000 tons of coal and $22,554,000$ tons of coke, which were respectively 60 and 70 per cent of Germany's total output of these products. The coal was taken from about 180 mines employing about 350,000 men.

In this field the highest perfection has been obtained in coke manufacture, with complete utilization of all by-products. Furthermore, it is a matter of record that the Westphalian coke, which is of the highest grade, is sold at a lower price than that made in France and Belgium. The accompanying diagram (fig. 7, p. 26) shows that 69 per cent of the coke used in smelting Lorraine ore in 1913 came from the Westphalian field.

COAL FIELDS WEST OF THE RHINE.

There are two coal fields (Aix-la-Chapelle and Bruggener-Erkelenz) within the pre-war German boundary west of the Rhine. These form an eastern extension of the Belgium fields, to be described below. The coals lie as deep as 1,500 meters, and the fields have a total area of about 1,200 square kilometers. They are more expensive to mine than the Westphalian coals and on account of this have not been developed to their full extent. In 1913 these fields produced $3,265,000$ tons of coal and 1,400,000 tons of coke. West of the lower Rhine, near Cologne, there is also an extensive field of lignite coal. This is developed on a large scale for making briquets. As its product is not used in the metallurgic industry this field need not here be discussed.

\section{SARRE COAL FIELD.}

The Sarre coal field, formerly a part of the German Empire but now, for a time at least, controlled by France, is described elsewhere in this rolume. It lies adjacent to the Lorraine iron field (Pl. I), but its best coking coals are far inferior to those of Westphalia. Their proximity to the iron, however, has led to their extensive use. Their efficiency in blast-furnace practice is about 67 per cent of that of the Westphalian coal. The Sarre coke can be effectively used in blast furnaces only by mixing it with at least 20 per cent of Westphalian or equally good coke. The Sarre field, as will be shown below, has extensive undeveloped reserves. 
BELGIAN COAL FIELDS.

The coal fields and the coal-mining and coking industry of Belgium are described by Maj. La Croix in a later section of this volume (pp. 80-124). Suffice it here to state that these fields have not been able to keep up with the domestic demands of the iron and steel industry for coking coal. In 1913, 23 per cent of the coke used in this industry was drawn from foreign sources, and of this 63 per cent came from Westphalia and 27 per cent from the Aix-la-Chapelle district. There are no great coal reserves in the developed parts of the Belgian coal fields, but the Campine Basin has been sufficiently explored to indicate that it can be looked to for a large supply of coking coal.

\section{SUMMARY.}

The above statement shows that by far the largest reserves of high-grade coking coal tributary to the Lorraine iron ore are in the

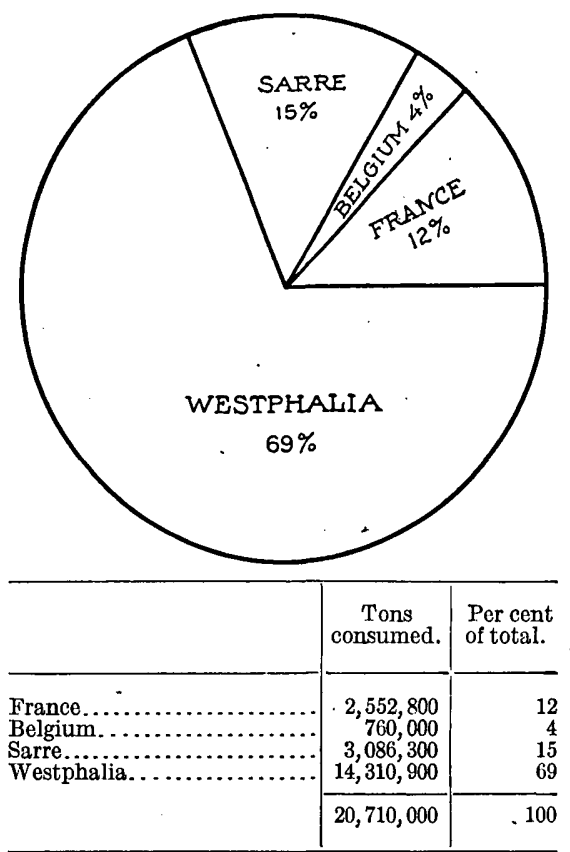

Figure 7.-Sources of coke used in smelting and refining Lorraine iron ore in 1913, including iron ore from French Lorraine, Lorraine Annexée, and Luxemburg.

The accompanying diagram (fig. 7) illustrates the preponderant part taken by the Westphalian coal in smelting the Lorraine ore.

This dominance of Westphalian coking coal in the smelting of the Lorraine iron ore is due partly to the German control, under pre-war conditions, of the iron and steel industry based on the Lorraine ore. this field is so closely tied to the Lorraine iron districts by water and rail transportation as to give it a decided advantage over any of the other fields, except the Sarre, whose coking coal is of an inferior grade. As a result the Sarre coke has found only a very local market in the metallurgic industry. On the other hand, Westphalian coking coal under pre-war conditions invaded not only Belgium but also French Lorraine. In 1913 French Lorraine consumed 2,229,000 tons of German coal, chiefly Westphalian, and 1,652,000 tons of coke from the same source. (See p. 43.) In the same year Belgian metallurgic industries consumed about 575,000 tons of German coking coal, chiefly from Westphalia.

Westphalian field. Moreover, 
This matter is considered in a later section of this report. It is also due to the fact that Westphalian coal and coke have been sold at a lower price than those of the competing fields. Facts in regard to this are set forth in the following table:

Prices of coal and furnace coke in coal fields tributary to Lorraine iron districts, 1909-1914, in francs per ton.

[1-rices are those of January 1 of each year at the place of produetion.]

\begin{tabular}{|c|c|c|c|c|c|c|c|c|}
\hline \multirow{3}{*}{ Year. } & \multirow{2}{*}{\multicolumn{2}{|c|}{$\begin{array}{l}\text { Trance (Valon- } \\
\text { ciennes field). }\end{array}$}} & \multicolumn{4}{|c|}{ Germany. } & \multirow{2}{*}{\multicolumn{2}{|c|}{ Belgium. }} \\
\hline & & & \multicolumn{2}{|c|}{ Sarre field. } & \multicolumn{2}{|c|}{ wiestphalian field. } & & \\
\hline & Coal. & Coke. & Coal. & Coke & Coal. & Coke. & Coal. & Coke. \\
\hline $\begin{array}{l}1909 \ldots \ldots \ldots \ldots \\
1910 \ldots \ldots \ldots \ldots \ldots \\
1911 \ldots \ldots \ldots \ldots \ldots \\
1912 \ldots \ldots \ldots \ldots \ldots \\
1913 \ldots \ldots \ldots \ldots \ldots \\
1914 \ldots \ldots \ldots \ldots \ldots\end{array}$ & $\begin{array}{l}17.50 \\
17.50 \\
18.50 \\
18.50 \\
20.00 \\
20.50\end{array}$ & $\begin{array}{l}21.50 \\
21.50 \\
22.10 \\
21.43 \\
26.19 \\
26.00\end{array}$ & $\begin{array}{l}14.75 \\
14.75 \\
14.75 \\
14.75 \\
16.00 \\
16.00\end{array}$ & $2 \mathrm{~s}$ & $\begin{array}{l}14.05 \\
13.45 \\
13.45 \\
13.20 \\
14.50 \\
15.45\end{array}$ & $\begin{array}{l}20.62 \\
18.75 \\
20.62 \\
20.62 \\
21.85 \\
21.25\end{array}$ & $\begin{array}{l}14.00 \\
13.00 \\
13.00 \\
13.50 \\
18.00 \\
16.00\end{array}$ & $\begin{array}{l}19.50 \\
19.50 \\
22.00 \\
22.00 \\
27.00 \\
22.00\end{array}$ \\
\hline
\end{tabular}

In the time available for the preparation of this paper it has not been possible to obtain complete data on the relative freight rates on coal and coke from the several coal fields. The facts on hand, however, clearly indicate that the freight rates from the coal fields to the iron districts are in general favorable to the Westphalian coal.

Though the Westphalian coal field is the natural source of coke for the Lorraine ore, yet if this source should be shut out by statute or regulation the Sarre and Campine basins could supply the coking coal. It will be shown that these two fields contain large reserves of coking coal which could in the next five years be sufficiently developed to furnish all the coking coals needed for the Lorraine ores. The following table summarizes the data relating to the reserves and possible future output of coking coal from the fields here discussed:

Coking coal in fields tributary to Lorraine iron field and estimate of production in 1924.

\begin{tabular}{|c|c|c|c|c|}
\hline Coal ficld. & $\begin{array}{l}\text { Reserves of } \\
\text { coking coal } \\
\text { (tons). } a\end{array}$ & $\begin{array}{c}\text { Coking } \\
\text { coal } \\
\text { produced, } \\
1913 \text { (tons). }\end{array}$ & $\begin{array}{c}\text { Estimated } \\
\text { production, } \\
1924 \text { (tons). }\end{array}$ & Remarks. \\
\hline Northern France....... & $1,000,000,000$ & & & \multirow{5}{*}{$\begin{array}{l}\text { J'roduction can probably not bo in- } \\
\text { creased. } \\
\quad \text { Do. } \\
\text { Under development. } \\
\text { Inferior in quality to other coking coals, }\end{array}$} \\
\hline $\begin{array}{l}\text { Belgian productive } \\
\text { ficld. }\end{array}$ & & & & \\
\hline $\begin{array}{l}\text { Campine Basin ......... } \\
\text { Sarre Basin .......... }\end{array}$ & $\begin{array}{r}64,000,000,000 \\
4,000,000,000\end{array}$ & $\begin{array}{l}\text { None. } \\
4,000,000\end{array}$ & $\begin{array}{l}8,000,000 \\
8,000,000\end{array}$ & \\
\hline \multirow{2}{*}{$\begin{array}{l}\text { Wostphalia ......... } \\
\text { Aix-la-Chapelle, Brug- } \\
\text { gen, and Crefeld. }\end{array}$} & $\begin{array}{r}10000,000,000 \\
35,000,000,000 \\
1.000,000,000\end{array}$ & $\begin{array}{r}10,890,000 \\
36,750,000 \\
1,400,000\end{array}$ & $\begin{array}{c}23,000,000 \\
\ldots \ldots \ldots \ldots\end{array}$ & \\
\hline & $46,000,000,000$ & $49,040,000$ & & \\
\hline
\end{tabular}


The preceding table shows that the Campine and Sarre basins contain ample reserves to smelt the Lorraine ore. Nor is there any doubt that if a market were available the annual production from these two fields, together with that from the other Belgian and French fields, could be brought up to the quantity needed for reducing Lorraine iron ore. It is, however, very doubtful whether the Campine and Sarre coals would be able to meet the competition of the Westphalian coals in an open market. It is certain that without trade restrictions a large part of the Lorraine ore would be smelted by the use of Westphalian coke.

\section{OWNERSHIP AND VALUE OF METALLURGIC PLANTS AND IRON LANDS.}

In the reports on the several districts are given detailed estimates on the value and information as to the ownership of iron lands and mines, blast furnaces, and steel plants. These reports summarize all the available data in regard to every corporation which has holdings in the region under discussion. The ownership is rather complex as regards the source of capital; for example, there are some corporations whose capital is from both French and German sources, and others in which Belgian and Luxemburg capital predominates or is represented. Again, some of the companies organized in France are owned on the German side of the frontier of 1913. The large ownership of German companies in French Lorraine iron lands has been referred to in a previous paragraph. There is also much German capital invested in the iron and steel industry of Belgium. About 85 per cent of all the iron lands of Lorraine and Luxemburg are owned by metallurgic companies. This is illustrated by the following table:

Corporate ownership of iron and steel plants and iron lands in Lorraine, Sarre district, Luxemburg, and Belgium, 1913.

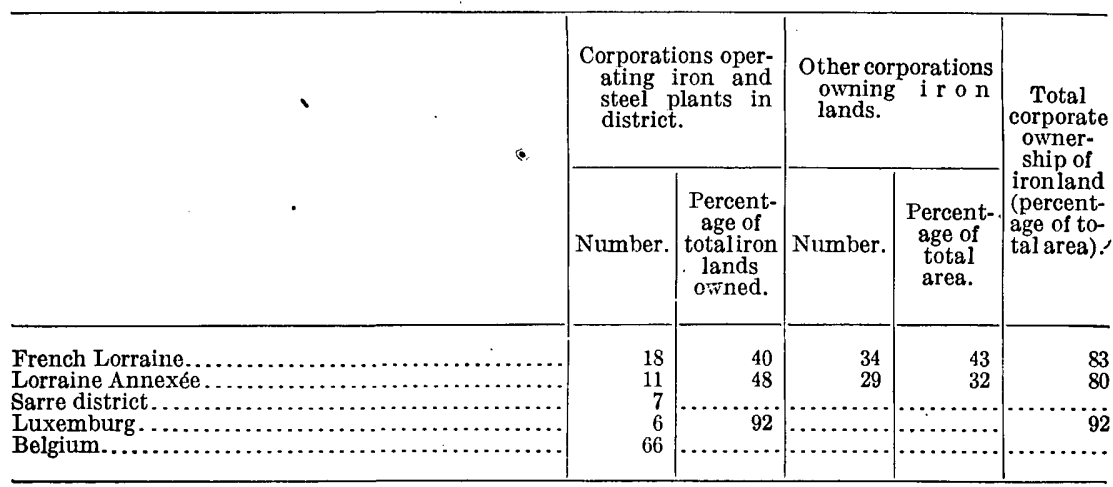


The metallurgic industry and mineral lands of Lorraine Annexée, the Sarre district, and Luxemburg are practically controlled by 14 corporations having a total capitalization of about $850,000,000$ francs. These corporations are listed in the following table:

German corporations controlling iron and steel industry of Lorraine Annexée, Sarre district, and Luxemburg.

\begin{tabular}{|c|c|}
\hline uxemburg. & $\begin{array}{l}\text { Capitalization } \\
\text { (francs). }\end{array}$ \\
\hline ütten u. Stahlwerk von Ste & $7,000,000$ \\
\hline uxemburgische. & $162,500,000$ \\
\hline rchener.... & $188,000,000$ \\
\hline oechling............ & $25,000,000$ \\
\hline Dillinger.............. & $21,100,000$ \\
\hline Stun & $27,000,000$ \\
\hline $\mathrm{B}$ & (?) \\
\hline inn. & $90,000,000$ \\
\hline Rom & $62,500,000$ \\
\hline Eisenwerke. & 0,000 \\
\hline$\ldots \ldots \ldots \ldots \ldots \ldots \ldots \ldots \ldots \ldots \ldots \ldots \ldots \ldots \ldots$ & $1,250,000$ \\
\hline$\ldots \ldots \ldots \ldots \ldots \ldots \ldots \ldots \ldots$ & $72,500,000$ \\
\hline Phoe & $132,500,000$ \\
\hline Gutehoffnungshütte... & $40,000,000$ \\
\hline & \\
\hline
\end{tabular}

The iron and steel industry of Lorraine is also affected by the combinations or syndicates of corporations known as "cartels," which are so important a feature of German industry. "Legally considered the cartel appears as a stock company of divers producers formed for the cooperative sale of their output or of certain classes of their product." 12 One of the strongest of these cartels is the "Rhenisch-Westphalischer Kohlen-Syndikat," which in 1913 controlled 90 per cent of the Westphalian coal trade. This cartel was able through its influence to prevent any large development of the coking coals of the Sarre Basin. Many of the large German steel corporations have become independent of this syndicate by acquiring coal mines and coke plants for their own use. In the time available for this investigation it has been impossible to study the effect of these combinations of corporations on the industries here described.

In making the valuations given in the district reports the best information available has been used. When more exact data were not available the following formulas have been used to determine actual values.

Iron lands: Valued at 8,000 to 10,000 francs per hectare; based on recent sale values.

Iron-mining plants: Valued at 2 francs per ton of annual production of iron ore; based on French and German published estimates.

Blast furnaces: Valued at 60 francs per ton of annual production; based on best information available. 
Steel plants, including full equipment and tributary blast furnaces: Valued at 300 francs per ton of annual production; based on best information available.

Coal land (Sarre district): Valued at 1,200 francs per hectare; based on recent sales.

Coal-mine equipment: Valued at 10 to 12 francs per ton of annual production of coal; based on records of War Damage Board.

Coke plants: Valued at 18 francs per ton of annual production; based on records of War Damage Board.

These unit values and such other more exact information as was available were used in preparing the subjoined estimates of the total value in 1913 of the mines and plants in the iron and steel industry, as well as of the German holdings in it:

Estimated value of German interests in iron and steel industry of Lorraine, Sarre district, Luxemburg, and Belgium, 1913.

\begin{tabular}{|c|c|c|c|}
\hline District. & $\begin{array}{c}\text { Total value of } \\
\text { iron mines and } \\
\text { iron and steel } \\
\text { plants } \\
\text { (francs). }\end{array}$ & $\begin{array}{c}\text { Value of Ger- } \\
\text { man holdings } \\
\text { in iron mines } \\
\text { and iron and } \\
\text { steel plants } \\
\text { (francs). }\end{array}$ & $\begin{array}{l}\text { Percent- } \\
\text { age of } \\
\text { German } \\
\text { holdings } \\
\text { to total } \\
\text { value in } \\
\text { each } \\
\text { region. }\end{array}$ \\
\hline \multirow[t]{2}{*}{ 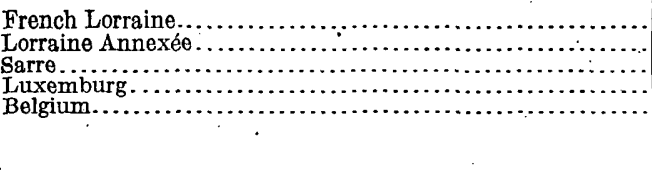 } & $\begin{array}{r}1,345,000,000 \\
1,191,000,000 \\
500,000,000 \\
414,000,000 \\
700,000,000 \\
\end{array}$ & $\begin{array}{l}100,000,000 \\
950,000,000 \\
425,000,000 \\
265,000,000 \\
125,000,000 \\
\end{array}$ & $\begin{array}{r}7.4 \\
80.0 \\
85.0 \\
64.0 \\
18.0 \\
\end{array}$ \\
\hline & $4,150,000,000$ & $1,865,000,000$ & 45.0 \\
\hline
\end{tabular}

Estimated value of German interests in Sarre coal lands and coal mines, 1913, in francs. [Coal lands 1,200 franes per hectare; coal mines 12 francs per ton of annual production; coke ovens 30,000 Prussian Government: francs each.)

Coal lands....................... 120,000, 000

Coal mines and equipment............. 160,000,000

Coke plants....................... 20,000,000

Bavarian Government: $300,000,000$

Coal lands....................... 5, 000,000

Coal mines and equipment............. 6, 000,000

Private coal and coke companies:

Coal lands...................... 50,000,000

Coal mines and equipment............. 44,000,000

Coke plants..................... 36,000,000

$130,000,000$

Less French interests.............. 30, 000, 000

$\frac{100,000,000}{411,000,000}$

In the course of the investigation many data have been collected on the profits of the industries connected with the mining and reduction of Lorraine iron ore. These are set forth in the accompanying 
reports, which show that in some districts fairly accurate figures on profits are available while in others such data are entirely lacking. Where no accurate data on profits have been available, the following figures have been assumed to be correct:

Iron ore, 0.75 to 1.50 francs per ton.

Pig iron, 8 francs per ton.

Raw and finished steel, 17 to 23 francs per ton.

The following table summarizes the data on profits for the entire industry, as well as the gross value of the output in 1913 . As a rule it was possible to obtain accurate figures on the market value of the product, and hence the figures on gross value in the following table are probably more accurate than those on profits.

Estimate of gross value and profits on iron ore, pig iron, and raw steel produced in districts using principally Lorraine iron ore, 1913.

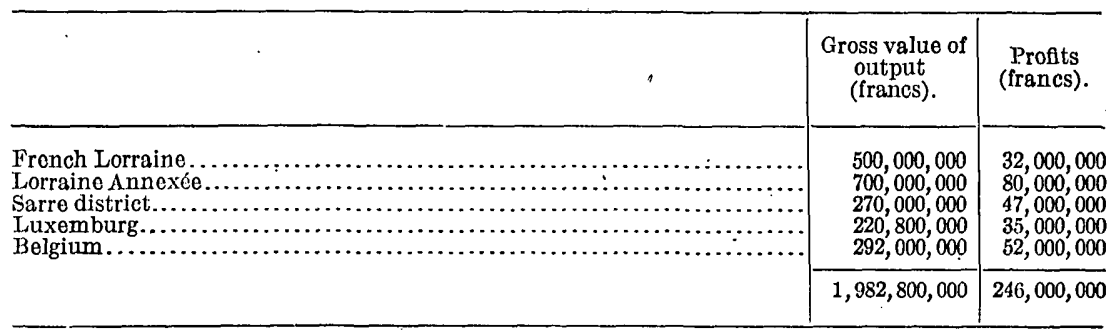

LABOR.

The following table shows the number of men employed in the industries here described. In both French Lorraine and Lorraine Annexée many Italian miners are employed, amounting to about half of the total. Luxemburg and Belgium also draw heavily on neighboring countries for the labor in their iron and steel industry. The other districts find their labor among their own nationals.

Men employed in iron mining and metallurgic industries of Lorraine, Luxemburg, Sarre district, and Belgium, 1913.

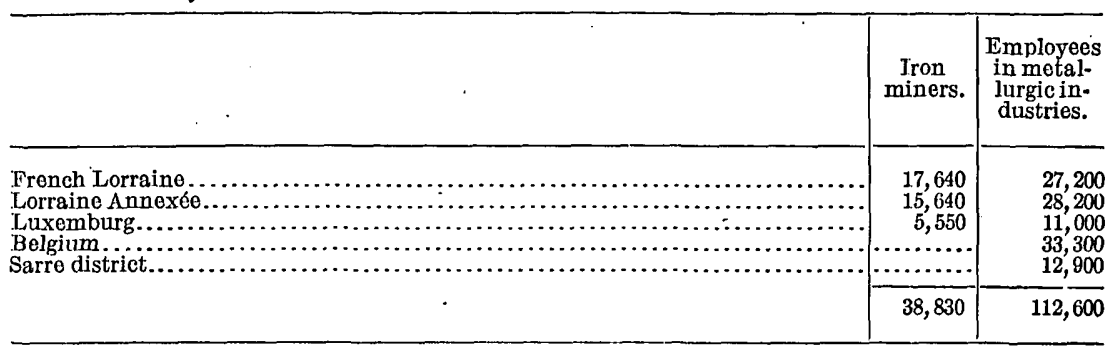

\section{IRON AND STEEL INDUSTRY.}

CONDITIONS DURING RECONSTRUCTION PERIOD.

The iron mines of the devastated zone of Lorraine have been relatively little damaged. Some machinery was removed and some injury was done by German war operations, but these conditions have 
not to any large extent reduced the producing possibilities of the mines. Even many of the deep mines were kept pumped out during the war, as they were operated by the Germans.

No doubt the German authorities knew full well that the future of their iron industry depended on Lorraine ores, and therefore they left the mines in the occupied territory comparatively intact. This policy contrasts strongly with their deliberate destruction of furnaces and steel plants which might be expected to come into competition with their own after the war. It is therefore safe to say that the output of iron from the Lorraine mines will be able to meet any immediate or near future requirements of the furnaces and steel plants, provided that there is a sufficient supply of skilled and unskilled labor and that the condition of the railroads permits the transport of the ore to the furnaces.

The problem, therefore, is not one of iron ore, but one of furnace and steel-plant capacity. In the subjoined table it is shown that before the war France produced 40 per cent of the total iron ore from Lorraine but smelted only 25 per cent of this total. She was therefore essentially an exporter of iron ore. Belgium produced practically no ore and was therefore an importer. Germany used large quantities of imported Lorraine ore.

Lorraine iron ore produced and consumed, 1919.

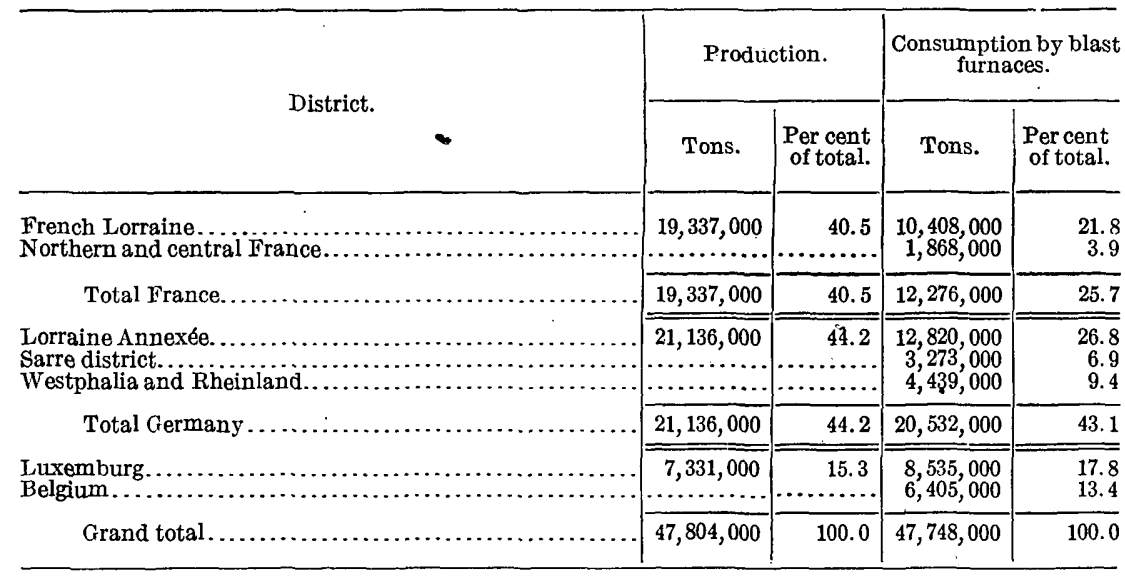

The destruction or serious damage of about 65 per cent of the French furnaces using Lorraine ore involves a corresponding loss in capacity for the consumption of this ore. The situation is somewhat improved by the return of Lorraine Annexée and the transfer in control of the Sarre district. The metallurgic plants of these districts, as shown by the above table, are large consumers of Lorraine ore. On the other hand, these two districts before the war were supplied with ore from the German side of the boundary, and they will afford no outlet for the surplus ore on the French side. Moreover, 
before the war Westphalia consumed about 4,500,000 tons of Lorraine ore. The subjoined table gives an estimate of the maximum capacity of the iron and steel plants using Lorraine ore. The estimates for the plants in the invaded region are based on the best information available. They are believed to represent the maximum annual capacity which will be available before the end of $1919,{ }^{12 a}$ but they do not take into account unfavorable conditions of labor or transportation.

Estimated capacity for 1919 of metallurgic plants which before the war smelted Lorraine iron ores.

\begin{tabular}{|c|c|c|c|c|}
\hline \multirow[b]{2}{*}{ Region. } & \multicolumn{2}{|c|}{ Blast furnaces. } & \multicolumn{2}{|c|}{ Steel plants. } \\
\hline & $\begin{array}{l}\text { Percent- } \\
\text { age of } \\
1913 \mathrm{ca}- \\
\text { pacity } \\
\text { available } \\
\text { in } 1919 .\end{array}$ & $\begin{array}{c}\text { A vailable } \\
\text { annual ca- } \\
\text { pacity in } \\
1919 \text { for } \\
\text { smelting } \\
\text { Lorraine } \\
\text { ore (tons). }\end{array}$ & $\begin{array}{l}\text { Percent- } \\
\text { age of } \\
1913 \text { ca- } \\
\text { pacity } \\
\text { available } \\
\text { in } 1919 .\end{array}$ & $\begin{array}{l}\text { Available } \\
\text { annual ca- } \\
\text { pacity in } \\
1919 \text { for } \\
\text { raw steel } \\
\text { (tons). }\end{array}$ \\
\hline 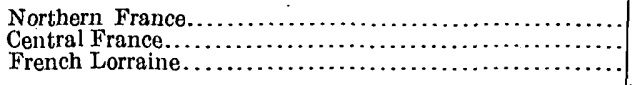 & $\begin{array}{r}30 \\
100 \\
35\end{array}$ & $\begin{array}{r}300,000 \\
a 800,000 \\
3,750,000\end{array}$ & $\begin{array}{r}\text { (?) } \\
100 \\
35\end{array}$ & $\begin{array}{l}b \\
c 450,000 \\
450,000\end{array}$ \\
\hline 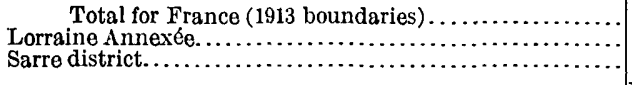 & $\begin{array}{r}47 \\
100 \\
100\end{array}$ & $\begin{array}{l}4,850,000 \\
1,300,000 \\
4,700,000\end{array}$ & $\begin{array}{l}100 \\
100\end{array}$ & $\begin{array}{r}600,000 \\
2,300,000 \\
2,100,000\end{array}$ \\
\hline 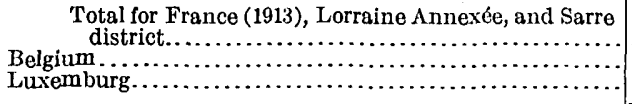 & $\begin{array}{r}40 \\
100\end{array}$ & $\begin{array}{r}10,850,000 \\
3,250,000 \\
8,800,000\end{array}$ & $\begin{array}{r}20 \\
100\end{array}$ & $\begin{array}{r}5,000,000 \\
475,000 \\
1,200,000\end{array}$ \\
\hline 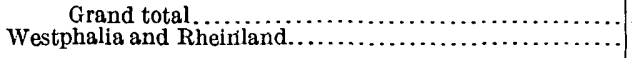 & 100 & $\begin{array}{r}22,900,000 \\
d 4,500,000\end{array}$ & ioo & $\begin{array}{c}6,675,000 \\
(e .)\end{array}$ \\
\hline
\end{tabular}

$a$ Pre-war annual capacity used for Lorraine ores. Much increased during war.

$b$ Pre-war annual steel production. Much increased during war.

c All steel plants and rolling mills totally destroyed in occupied area except two near Longwy, which were seriously damaged. Two plants in Nancy district practically intact.

$d$ The total annual capacity of Westphalian and Rheinland blast furnaces was 8,840,000 tons of pig, equal to $26,500,000$ tons of Lorraine ore.

$e$ The steel production of Westphalia and Rheinland in 1913 was $10,112,000$ tons.

The preceding table shows that the existing furnaces of France, including Lorraine Annexée and the Sarre district, will be able to consume in 1919 less than 11,000,000 tons of ore, or only about 25 per cent of the pre-war ${ }^{\circ}$ production of ore in Lorraine. Adding to this the requirements of the Luxemburg plants and what is left of the Belgian plants gives a total of not over $23,000,000$ tons, or less than half of the pre-war output. This ore will yield about 7,200,000 tons of pig, which in turn will exceed the estimated capacity of the steel plants by about 800,000 tons. ${ }^{12 b}$ An excess of pig iron, how-

\footnotetext{
12n These figures will be somewhat modified by adding the capacity of iron and steel plants built during the war, details about which are as yet lacking. The new steel plants can probably use the Lorraine pig iron. The economic possibility of using the new furnaces for Lorraine iron ore will depend on the cost of transportation.

12b When thess statisties were compiled no information was available about the French iron and steel plants constructed during the war. These new plants will materially increase the total capacity. Compare Wood, C. P., Commerce Repts., March 20, 1920, p. 1591.
} 
ever, will not be a serious drawback, as this might be shipped to England or to some of the steel plants of France, which under pre-war conditions could not economically use the Lorraine pig.

It is important to. note that this estimate of the consumption of iron ore for the manufacture of steel, assuming the control of the Sarre district, presupposes that the skilled labor will be available for the operation of the iron and steel plants. No facts bearing on this point are at hand, but it is likely to be a vital one in the whole problem. There is also the all-important question of a market for the aboveestimated possible steel production. In 1913 France produced 4,400,000 tons of steel, which was consumed chiefly in France. Belgium's output in the same year was $2,600,000$ tons, of which 80 per cent was exported. The above estimates, leaving out Luxemburg, would give France and Belgium about 5,500,000 tons of steel. This would probably not be an oversupply for domestic use, however, in view of the enormous amount of reconstruction to be done. It has been shown that the furnace and steel plants can at best consume not more than 23,000,000 tons of ore. Even this consumption involves the use of railroads in France and Belgium which are more or less crippled and might not be able to handle a large tonnage. The production of the mines, however, if labor were available, could probably within a year be brought up to double that amount. This surplus ore, if it could be sold, would form an important asset to France in her present impoverished condition. If this ore were shipped to the Westphalian or Rhine furnaces, they would make little use of French or Belgian railroads and would not interfere with other traffic.

It has been suggested that the excess of Lorraine ore might be shipped to England, but this does not seem to be economically possible, for the ore is of too low a grade to stand the present high cost of transportation, and most of the English plants are not designed for the use of basic ores.

Serious consideration should therefore be given to a plan for developing the Lorraine iron mines to their full capacity so far as labor conditions permit; the ore which can not be consumed by French and Belgian plants should be shipped to Westphalia, and the German plants should be required to furnish iron and steel products to be used in the rebuilding of the industrial plants of the devastated areas.

CONDITIONS AFTER RECONSTRUCTION PERIOD.

The period required for the restoration of the war-damaged iron and steel plants has been variously estimated at two to five years. Assuming that it will take five years, and that the restoration will bring the capacity of these plants only back to that of the pre-war period, the following table summarizes the situation: 
Estimate of minimum capacity of iron and steel plants dependent on Lorraine ore, 1924, in tons.

\begin{tabular}{|c|c|c|}
\hline . & Furnaces. & $\begin{array}{c}\text { Steel } \\
\text { plants. }\end{array}$ \\
\hline 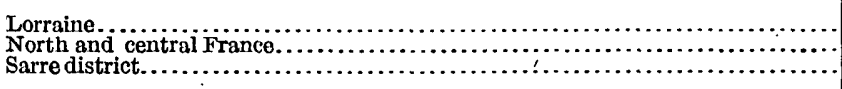 & $\begin{array}{r}23,000,000 \\
2,000,000 \\
3,500,000\end{array}$ & $\begin{array}{r}4,600,900 \\
300,000 \\
2,100,000\end{array}$ \\
\hline 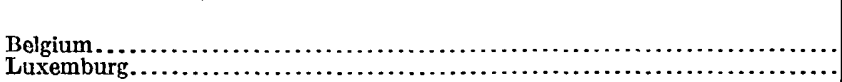 & $\begin{array}{r}28,500,000 \\
6,500,000 \\
8,500,000\end{array}$ & $\begin{array}{l}7,000,000 \\
2,5000,000 \\
1,200,000\end{array}$ \\
\hline & $43,500,000$ & $10,700,000$ \\
\hline
\end{tabular}

According to this estimate the iron and steel plants using Lorraine ore, not including those in Westphalia or the Rheinland, will at the end of the reconstruction period, or not later than 1924, be capable of consuming at least $43,500,000$ tons of ore and producing $10,700,000$ tons of steel. This will still leave over $4,000,000$ tons of the normal production to be taken care of-about the amount which in 1913 was consumed by the Westphalian plants. It is quite possible that the reconstruction may be fully capable of absorbing this additional ore. Even this, however, would not solve the problem, for in 1913 it was expected that within five years the production of the Lorraine field would be increased by 10,000,000 tons. Plans and investments were made with this end in view, and many large mines were opened in the Briey district. If no market can be found for this ore, the French mine operator will be left with no returns on the capital invested in these enterprises. Therefore, it is highly desirable that provision be made for the consumption of this extra production. There seems to be no alternative for the smelting of this ore except to transport it to the Rheinland and reduce it in the German plants that use Westphalian coke.

\section{SUMMMARY AND CONCLUSIONS.}

France's ownership of the Lorraine iron deposits will give her the dominating position in Europe as an iron-ore producer. Even with the Sarre coal field, France will not be able to produce the coke to reduce this ore in competition with that from the Westphalian coal fields. Belgium has no iron deposits of importance, but the great deposits of coking coal in the Campine field and her geographic position assure her an important position in the iron and steel industry, for Belgium lies between the Lorraine field and the nearest practical route to tidewater. After reconstruction she will probably consume more Lorraine ore than she did before the war. The reestablishment of the iron and steel plants of France in the devastated area, together with those of Lorraine Annexée and the Sarre district, should make requirements for at least 27,000,000 tons, the amount used before the war, and probably more. 
An estimate of the possible consumption in the several districts after the reestablishment of normal conditions should take into account the possible market for the product. It is assumed that France and Belgium will after the reconstruction be able to compete in the world's market for the iron and steel trade. In the case of France, which has not been primarily an export nation, has no great industrial population, and has not always shown the technical and financial skill of her competitors, this assumption is perhaps hazardous. However, it is here assumed that France will become an exporter of steel and iron manufactures. The following table will give an indication of the possible iron-ore consumption:

Estimate of consumption of Lorraine ore after iron and steel industry is reestablished and enlarged.

Tons.

Lorraine and other parts of France.......... 25, 000, 000-30, 000, 000

Sarre district........................ 5, 000, 000-10, 000, 000

Luxemburg.......................... $8,000,000-10,000,000$

Belgium........................... 10,000, 000-15, 000, 000

$48,000,000-65,000,000$

It has been shown that the iron output of the Lorraine field could probably in five years be brought up to $60,000,000$ tons. If the above estimates are correct, France and Belgium might consume the entire supply. For the reasons given it is not likely that this possibility will be realized. There is good reason to believe that at best French and Belgian iron and steel plants will never be able to consume the entire product of the Lorraine ore field. Therefore, if this ore is to be used it will have to be sent to Westphalia and the Rheinland. There is reason to believe that the field may produce $10,000,000$ tons of ore annually in excess of French and Belgian requirements.

The economic situation in regard to the use of Lorraine iron ore during and after the reconstruction period can be summarized in the following statements:

1. During the reconstruction period the capacity for Lorraine iron ore in the furnaces and steel plants will range from about 20,000,000 tons in the first year to 50,000,000 tons in the fifth year (1924).

2. During the reconstruction period it will be necessary to draw on the Westphalian coal for a part of the coke needed in the furnaces and steel plants.

3. The iron mines, provided labor and transportation are available, can produce ore as required up to an annual rate of about $50,000,000$ tons during the first year of operations.

4. If the iron mines are worked to their full capacity the excess ore produced can be sold only to the Westphalian and Rheinland plants. ${ }^{12 \mathrm{c}}$

\footnotetext{
12c In June, 1920, a tomporary agreement was made between France and Germany by which 200,000 tons of Lorraine ore was to be shipped to German furnaces at 16 to 26 francs a ton f. o. b. (Stahl und Eisen, vol. 40 , p. 895,1920 .)
} 
5. There is a strong probability that even after the construction of new iron and steel plants, the Lorraine iron-ore producing capacity will exceed the demands of the French, Belgian, and Luxemburg metallurgic plants.

6. In not over five years the Sarre and Campine coal fields may be able to produce all the coke needed to smelt the entire output of Lorraine iron ore.

7. In an open market the Sarre and Campine coking coals will always find a strong competitor in the coal from Westphalia.

8. There are urgent economic reasons for the adoption of a policy by which the Westphalian coal mines shall be permitted to furnish a part of the coking coal and coke required for the Lorraine ores. ${ }^{12 \mathrm{~d}}$

The above statements point to the following conclusions:

1. Both during the reconstruction period and after the reestablishment of the metallurgic industries, Westphalian coal and coke should not be shut out from use in this field.

2. During the reconstruction period the Lorraine iron mines should be worked to their full capacity, and the surplus ore should be reduced in the Westphalian and Rheinland metallurgic plants, with a provision that the iron and steel reduced shall be turned over to France and Belgium for use in reconstruction.

3. Shipments of Lorraine ores to German plants should be continued after the reconstruction period.

If an attempt is made to prevent the exchange of raw materialthat is, Lorraine iron ore for Westphalian coke and coal-it will prevent the economic use of both of these resources. Suck restrictions will have the ultimate effect of raising the cost of producing iron and steel. Any attempt to circumvent economic laws by political action will be to the detriment of the ultimate consumer and hence to the disadvantage of the average European, whatever his nationality. It may also prevent French and Belgian iron and steel products from competing in the world market.

\section{FRENCH LORRAINE.}

By Alfred H. Brooks.

\section{INTRODUCTION.}

In 1913 French Lorraine contained over 75 per cent of the known iron-ore reserves of France and produced 90 per cent of the iron ore, 67 per cent of the pig iron, and 50 per cent of the steel, through the operation of 54 mines, employing 17,640 men, and 25 iron and steel plants, employing 27,184 men. These plants included 72 blast furnaces, in addition to 17 not in operation.

The mines and the iron and steel plants are owned by 62 corporations and individuals, of which 18 are metallurgic companies that

12d By the terms of the treaty Germany is required to furnish to France 7,000,000 tons of coal annually for ten yoars, in addition to an amount equivalent to that lost by France owing to the destruction of her mines. 
also own iron lands. The combined capitalization of all these companies is about $400,000,000$ francs. In 1913 the gross value of the total output of the mines and metallúrgic plants was about $500,000,000$ francs. A rough estimate indicates that the profit on these industries in 1913 was about $32,000,000$ francs.

\section{IRON-ORE DEPOSITS.}

The French Lorraine iron field comprises three principal districts. (See Pl. I.) The largest is the Briey district, which is not sharply differentiated from the Longwy district, lying to the north, the second in reserves and in production. The smallest is the Nancy district, which lies to the south and is entirely isolated from the other two. Between the Briey and Longwy districts is the little-developed Crusnes district, which contains important reserves of iron ore.

Areas, iron-ore reserves, and production of French Lorraine iron field.

\begin{tabular}{|c|c|c|c|}
\hline District. & $\begin{array}{c}\text { Area of con- } \\
\text { cessions } \\
\text { (hectares) }\end{array}$ & $\begin{array}{l}\text { Iron-ore re- } \\
\text { serves in } 1909 \\
\quad \text { (tons). }\end{array}$ & $\begin{array}{l}\text { Production } \\
\text { in 1913 } \\
\text { (tons). }\end{array}$ \\
\hline \multirow[t]{2}{*}{ 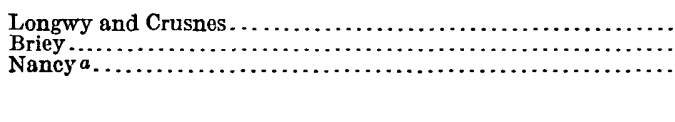 } & $\begin{array}{l}12,000 \\
43,000 \\
12,000 \\
\end{array}$ & $\begin{array}{r}800,000,000 \\
2,000,000,000 \\
200,000,000 \\
\end{array}$ & $\begin{array}{r}2,647,000 \\
14,841,000 \\
1,908,000 \\
\end{array}$ \\
\hline & 67,000 & $3,000,000,000$ & $19,396,000$ \\
\hline
\end{tabular}

$a$ There are said to be 6,000 hectares of iron lands in Nancy district for which concessions have not been granted.

The iron occurs in beds of varying thickness, with a maximum of 5 meters. The beds are more or less lenticular in form, dip gently to the west, and are broken by some large dislocations. In the plateau regions of Longwy and Nancy the beds crop out on the valley walls, but in the Briey and Crusnes districts they lie at considerable depth.

The ore, which is called minette, is an oolitic limonite carrying from 25 to 48 per cent of iron, with an average of about 32 per cent for the mine run. The export ore probably carries about 38 per cent of iron. The Briey ores are the richest, carrying in general from 36 to 40 per cent of iron. Their value is increased by the high content of lime, which runs from 10 to 15 per cent. In the Longwy Basin the iron content is from 25 to 40 per cent, with an average less than than that of Briey. The Nancy ores are of still lower grade. Both the Longwy and the Nancy ores carry more silica than lime. The phosphorus content of the ores of all these districts is from 1.7 to 2.0 per cent, making them suitable for economical treatment by the basic process of steel making.

\section{CONCESSIONS.}

In France ownership of land does not carry with it the mineral deposits such as coal and iron, which are the property of the State until granted by concessions. Concessions are made only to citizens 
of France (including naturalized citizens), either as individuals or associated in corporations. The concessions are perpetual and allow the sale of property, thus permitting it to be acquired by foreigners. Provisions are made for payment of damages to owners of surface rights. Most of the concessions provide for a fixed annual rental of 10 francs per square kilometer and a tax which is determined annually in the national budget but which may not exceed 6 per cent on the net profits of mining.

The law of 1910 provided for a surface tax of 50 centimes per hectare on all iron lands and 6 per cent on the net profits of iron mining. Of the latter 5 per cent goes to the National Government and 1 per cent to the local community. In 1913 the French Lorraine iron mines and lands paid a total tax of about 1,050,000 francs, equal to about 5 centimes per ton.

There appears to be no limit to the size or number of concessions, but these are granted only by the Conseil d'état. In the last two decades the obtaining of concessions to mineral lands in France has been far less easy than it was before. Most of the iron lands containing the more or less readily accessible ores of Lorraine had been conceded before this change in policy. The new policy has, however, tended to discourage the search for possible extensions of the iron fields by deep drilling. The total number of iron-land concessions granted up to the end of 1913 was 112 , aggregating some 67,000 hectares. This land is now owned by 62 companies, with an aggregate capitalization of about $400,000,000$ francs. As will be shown below, this capital in part represents the value of iron and steel plants.

\section{MINING.}

The high topographic position of the iron-ore beds in the Longwy and Nancy districts has made it possible to develop them by adits driven into the valley slopes and to transport the ore by gravity. Formerly there was considerable open-pit mining in the Longwy district, but as the ore near the surface became exhausted this form of mining declined. In 1913 only about 1 per cent of the ores of French Lorraine were taken from open pits.

In the Briey field the ore lies deep (200 to 250 meters) and can be recovered only by shafts. As these shafts penetrate a water-bearing zone the mine costs are considerably increased by the expense of pumping. The same physical conditions will be encountered when the Crusnes district is developed.

The average cost of mining in the entire field during 1913 was about 3.80 francs to the ton. At this cost the average profits were about 1.10 francs to the ton. The cost of mining in the Briey Basin in 1913 was from 3.50 to 4.75 francs, and in the Longwy district from 2.60 to 4 francs to the ton. The cheaper recovery in the Longwy 
district as compared with the deep mines of Briey is in part compensated by the larger operations in the Briey field. In the Longwy district the average output per mine in 1913 was 275,000 tons, compared with an output of 800,000 tons per mine in the Briey district.

In 1913 the average daily wage in French Lorraine was 4.62 francs for surface work and 6.35 francs for underground work. The average annưal recovery per employee (underground and surface) was about 1,000 tons.

It was the introduction of the basic process of making steel that gave the first great impetus to the use of the iron ores of Lorraine. The phosphorus content of these ores is too large to admit of their being used by the acid process. The first plants in French Lorraine equipped with Thomas converters were built in 1880, and since that time the annual ore production has steadily increased.

Iron ore produced in French Lorraine, 1904-1918.

\begin{tabular}{|c|c|c|c|c|c|}
\hline . & $\begin{array}{l}\text { Quantity } \\
\text { (tons). }\end{array}$ & $\begin{array}{l}\text { Per cent } \\
\text { of total } \\
\text { produc- } \\
\text { tion of } \\
\text { France. }\end{array}$ & ' & $\begin{array}{l}\text { Quantity } \\
\text { (tons). }\end{array}$ & $\begin{array}{l}\text { Per cent } \\
\text { of total } \\
\text { produc- } \\
\text { tion of } \\
\text { France. }\end{array}$ \\
\hline 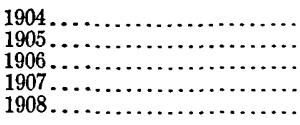 & $\begin{array}{l}5,954,000 \\
6,399,000 \\
7,399,000 \\
8,822,000 \\
8,850,000\end{array}$ & $\begin{array}{l}84.7 \\
86.5 \\
87.2 \\
88.1 \\
88.0\end{array}$ & 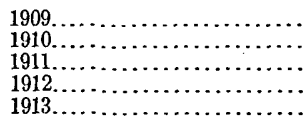 & $\begin{array}{l}10,673,000 \\
13,210,000 \\
15,054,000 \\
17,371,000 \\
19,629,000\end{array}$ & $\begin{array}{l}89.7 \\
89.9 \\
90.5 \\
90.1 \\
89.6\end{array}$ \\
\hline
\end{tabular}

The great increase of output during the decade, as shown by the above table, is due entirely to the growth of the production in the Briey district, which increased from $1,600,000$ tons in 1904 to $14,800,000$ tons in 1913. During this period there has been little change in the annual output of the Longwy and Nancy districts.

It will be shown below that the increase in the production of pig iron and steel in France has not kept pace with the increase in the output of iron ore. A foreign market has therefore had to be sought. This has been found in Belgium and in Westphalia. The Belgian consumption of ores from French Lorraine increased enormously during the decade before the war and the Westphalian consumption doubled during the last five years of that decade, as shown in the table below. It is estimated that the large developments in the Briey field that were well advanced in 1913 would soon bring the annual iron-ore output of Lorraine to about 25,000,000 tons. Most of this ore would have to find a market outside of France, and under the prewar conditions it would have been absorbed by Westphalia as well as by Belgium. The Briey ore is the best in the Lorraine field and can bear transportation better than that from Lorraine Annexée and Luxemburg. 
Approximate distribution of iron ores from French Lorraine, 1904-1919, in tons.

\begin{tabular}{|c|c|c|c|c|c|c|c|}
\hline \multirow[b]{2}{*}{ Year. } & \multicolumn{2}{|c|}{ France. } & \multirow[b]{2}{*}{ Belgium. } & \multirow[b]{2}{*}{$\begin{array}{l}\text { Luxem- } \\
\text { burg. }\end{array}$} & \multicolumn{2}{|c|}{ Germany. } & \multirow{2}{*}{$\begin{array}{l}\text { Other } \\
\text { coun- } \\
\text { tries. }\end{array}$} \\
\hline & $\begin{array}{l}\text { Lorraine } \\
\text { district. }\end{array}$ & $\begin{array}{c}\text { Other } \\
\text { districts. }\end{array}$ & & & $\begin{array}{c}\text { Lorraine } \\
\text { Annexée } \\
\text { and Sarre. }\end{array}$ & $\begin{array}{c}\text { Westphalia } \\
\text { and } \\
\text { Rheinland. }\end{array}$ & \\
\hline 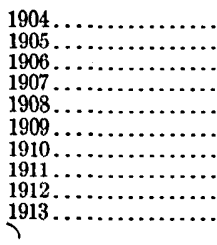 & $\begin{array}{l}4,888,000 \\
5,055,000 \\
5,667,000 \\
6,131,000 \\
5,973,000 \\
6,540,000 \\
7,627,000 \\
8,238,000 \\
9,140,000 \\
9,616,000\end{array}$ & $\begin{array}{r}400,000 \\
419,000 \\
435,000 \\
623,000 \\
908,000 \\
708,000 \\
1,231,000 \\
1,343,000 \\
1,737,000 \\
2,002,000\end{array}$ & $\begin{array}{r}406,000 \\
645,000 \\
817,000 \\
1,026,000 \\
1,188,000 \\
2,261,000 \\
2,885,000 \\
3,689,000 \\
4,355,000 \\
4,697,000\end{array}$ & $\begin{array}{r}92,000 \\
164,000 \\
166,000 \\
251,000 \\
281,000 \\
389,000 \\
477,000 \\
349,000 \\
627,000 \\
1,201,000\end{array}$ & $\begin{array}{r}158,000 \\
106,000 \\
264,000 \\
351,000 \\
350,000 \\
400,000 \\
400,000 \\
575,000 \\
550,000 \\
1,035,000\end{array}$ & $\begin{array}{r}10,000 \\
10,000 \\
50,000 \\
140,000 \\
150,000 \\
370,000 \\
610,000 \\
835,000 \\
820,000 \\
1,002,000\end{array}$ & $\begin{array}{r}5,000 \\
10,000 \\
25,000 \\
52,000 \\
76,000\end{array}$ \\
\hline
\end{tabular}

The ore shipped from French Lorraine into Westphalia goes in part by rail and in part by rail and water (rail to Pagny-sur-Moselle and thence by canal). About one-fifth of the French Lorraine ore received in the Westphalian district comes by water. In 1910 the freight rate per ton from Homécourt, in the Briey district, to Westphalia was 8.50 francs by rail and 8.80 francs by rail and water, including transfer charges. This rate makes the cost of ore delivered at Westphalia furnaces about 13 francs per ton, and the cost of ore per ton of pig about 42 francs. A little ore is shipped from French Lorraine by rail to Givet and thence by canal to Westphalia.

Most of the ore shipped from French Lorraine to Belgium is from the Briey district and goes by rail. In 1913 the freight rate on iron ore from Homécourt, in the Briey district; to Liége furnaces, by rail, was 4.80 francs a ton. An alternate route is by rail to Givet and thence by canal to Liége. The freight rate by rail to Givet was 3.70 francs a ton, including unloading charges (50 centimes). To compete with the direct rail route the canal would have to haul iron ore to Givet, a distance of 115 kilometers, for less than 1 franc a ton. A lower freight rate by this route has not been practical, because of the lack of a return cargo. If Belgian coal were extensively used in French Lorraine, it should be possible to obtain a cheaper freight rate for the iron ore bound north. Some of the ore exported to Westphalia goes by canal from Givet, and much German coal is brought into France by this route. A little iron ore (106,000 tons in 1913) is exported to Belgium from the Nancy district by way of the Meuse Canal, the return cargoes being Belgian coal.

The above-cited freight rates would make the cost of Briey ore at Liége furnaces not over 10 francs a ton. This gives the Liége furnaces an apparent advantage over the Westphalian furnaces amounting to some 3 francs a ton.

The ore exported to Luxemburg goes chiefly from the Briey district, by rail. The ore shipped to the Sarre district, which is largely from 
the Briey district, goes either by all rail (freight rate in 1910, 4 francs a ton) or by rail to Pagny-sur-Moselle and thence by canal (freight rate in 1910, 4.60 francs a ton, including transfer charges). Exports to Lorraine Annexée go by rail, and about three-fourths of these are from the Briey district.

During the two years preceding the war some small shipments (25,000 to 75,000 tons) of Lorraine ore were made to Great Britain, and plans were under consideration for developing this market. The long haul and cost of rehandling would seem to argue against the use of Lorraine ore in England, where it would be in competition with high-grade ores brought in by water routes.

\section{MANUFACTURE OF PIG IRON AND STEEL.}

In 191372 blast furnaces having a total daily capacity of about 10,800 tons were operated in French Lorraine. These furnaces imported some iron ore from Luxemburg and Lorraine Annexée but were supplied chiefly from local sources. The development of the pig iron and steel industry in this field during the decade before the war and the sources of its iron ore are shown in the following tables. Most of the steel is produced in Thomas converters. Of the total of $2,298,700$ tons of steel produced in 1913, only 157,200 tons was made by Martin furnaces.

Iron ore smelted in French Lorraine, 1904-1913, by sources, in tons.

\begin{tabular}{|c|c|c|c|}
\hline Year. " & $\begin{array}{l}\text { French } \\
\text { Lorraine. }\end{array}$ & $\begin{array}{l}\text { Luxem- } \\
\text { burg. }\end{array}$ & $\begin{array}{l}\text { Lorraine } \\
\text { Annexée. }\end{array}$ \\
\hline 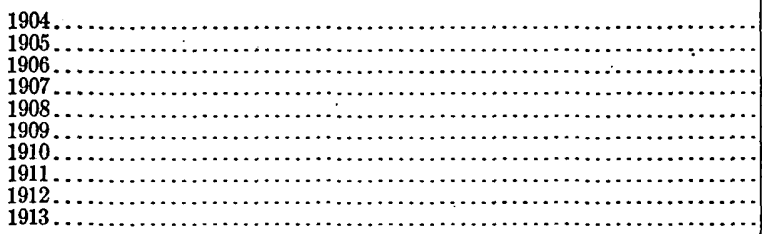 & $\begin{array}{l}4,888,000 \\
5,055,000 \\
5,667,000 \\
6,131,000 \\
5,973,000 \\
6,540,000 \\
7,627,000 \\
8,238,000 \\
9,140,000 \\
9,616,000\end{array}$ & $\begin{array}{l}888,000 \\
940,000 \\
841,000 \\
846,000 \\
499,000 \\
395,000 \\
377,000 \\
350,000 \\
367,000 \\
316,200\end{array}$ & $\begin{array}{l}530,000 \\
606,000 \\
613,000 \\
601,000 \\
515,000 \\
505,000 \\
592,000 \\
490,000 \\
469,000 \\
517,000\end{array}$ \\
\hline
\end{tabular}

Pig iron and steel produced in French Lorraine, 1904-1913, in tons.

\begin{tabular}{|c|c|c|c|}
\hline Year. & Pig iron. & Steel. & $\begin{array}{l}\text { French Lor- } \\
\text { raine pig } \\
\text { iron ship- } \\
\text { ped to other } \\
\text { parts of } \\
\text { France. }\end{array}$ \\
\hline 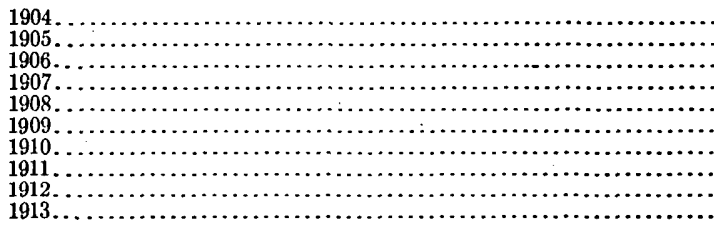 & $\begin{array}{l}2,001,150 \\
2,108,760 \\
2,295,170 \\
2,495,350 \\
2,289,470 \\
2,428,850 \\
2,756,210 \\
3,012,110 \\
3,402,670 \\
3,492,730\end{array}$ & $\begin{array}{r}997,925 \\
1,110,055 \\
1,212,417 \\
1,358,684 \\
1,265,130 \\
1,433,823 \\
1,653,310 \\
1,867,168 \\
2,195,173 \\
2,298,717\end{array}$ & $\begin{array}{r}940,000 \\
1,023,000 \\
739,000 \\
1,040,000 \\
880,000 \\
768,000 \\
900,000 \\
1,000,000 \\
1,000,000 \\
1,000,000\end{array}$ \\
\hline
\end{tabular}


The coke used by the metallurgic plants of French Lorraine is brought from the Nord and Pas-de-Calais basins in northern France, from Westphalia, and from Belgium. Though the Sarre coal field is close at hand, its coke is inferior to that from the above-named sources and hence is but little used. The quantities of coke and coal used in the iron and steel plants of French Lorraine are shown in the following table:

Coke and coal consumed by iron and steel works of French Lorraine, 1904-191s, in tons.

\begin{tabular}{|c|c|c|c|c|c|}
\hline Year. & Coke. & Conl. & Year. & Coke. & Coal. \\
\hline $\begin{array}{l}1904 \ldots \ldots \ldots \ldots \\
1905 \ldots \ldots \ldots \ldots \\
1906 \ldots \ldots \ldots \\
1907 \ldots \ldots \ldots \\
1908 \ldots \ldots \ldots \ldots\end{array}$ & $\begin{array}{l}2,655,000 \\
2,796,683 \\
2,968,396 \\
3,186,965 \\
2,807,160\end{array}$ & $\begin{array}{l}250,000 \\
291,399 \\
355,427 \\
523,741 \\
469,515\end{array}$ & 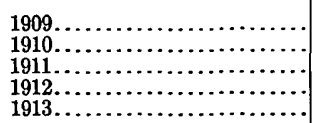 & $\begin{array}{l}2,927,890 \\
3,255,205 \\
3,467,768 \\
3,695,880 \\
4,074,820\end{array}$ & $\begin{array}{l}471,454 \\
541,691 \\
511,900 \\
545,545 \\
592,830\end{array}$ \\
\hline
\end{tabular}

The source of the coke and coal used in French Lorraine during 1912 and 1913 is shown in the subjoined table. There are no data at hand for the source of fuels previous to 1912 , but it is probable that they were drawn from German and French fields in about the same proportion as shown in the table.

Coke and coal consumed in French Lorraine, 1912-13, by sources, in tons.

\begin{tabular}{|c|c|c|c|c|}
\hline \multirow{2}{*}{ Source. } & \multicolumn{2}{|c|}{1912} & \multicolumn{2}{|c|}{1913} \\
\hline & Coke. & Coal. & Coke. & Coal. \\
\hline \multirow[t]{2}{*}{ 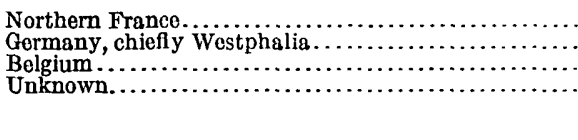 } & $\begin{array}{r}1,121,670 \\
2,213,520 \\
203,000 \\
157,650\end{array}$ & $\begin{array}{r}347,920 \\
1,415,750 \\
164,650 \\
\end{array}$ & $\begin{array}{r}1,596,000 \\
2,229,430 \\
248,980 \\
410\end{array}$ & $\begin{array}{r}400,000 \\
1,652,240 \\
162,480\end{array}$ \\
\hline & $3,695,840$ & $1,928,320$ & $4,074,820$ & $2,214,720$ \\
\hline
\end{tabular}

No coke plants have been operated in French Lorraine. At the outbreak of the war some coke ovens were in course of construction near Auboué, in the Briey district.

\section{OWNERSHIP OF IRON LANDS AND METALLURGIC YLANTS.}

The subjoined tables show the ownership of the French Lorraine iron mines and metallurgic plants. The metallurgic plants are owned by 18 companies having a total capitalization of $207,000,000$ francs. All the furnace and steel companies own iron lands, their total holdings aggregating 26,435 hectares, or nearly 40 per cent of the total known area of iron lands. The rest of the iron lands are owned by mining companies. The total number of companies owning iron lands and metallurgic plants is 62 , and their capitalization is about $400,000,000$ francs. This includes the furnace and steel companies and therefore represents the approximate total capitalization of the iron mines and lands, blast furnaces, and steel plants of French Lorraine. 


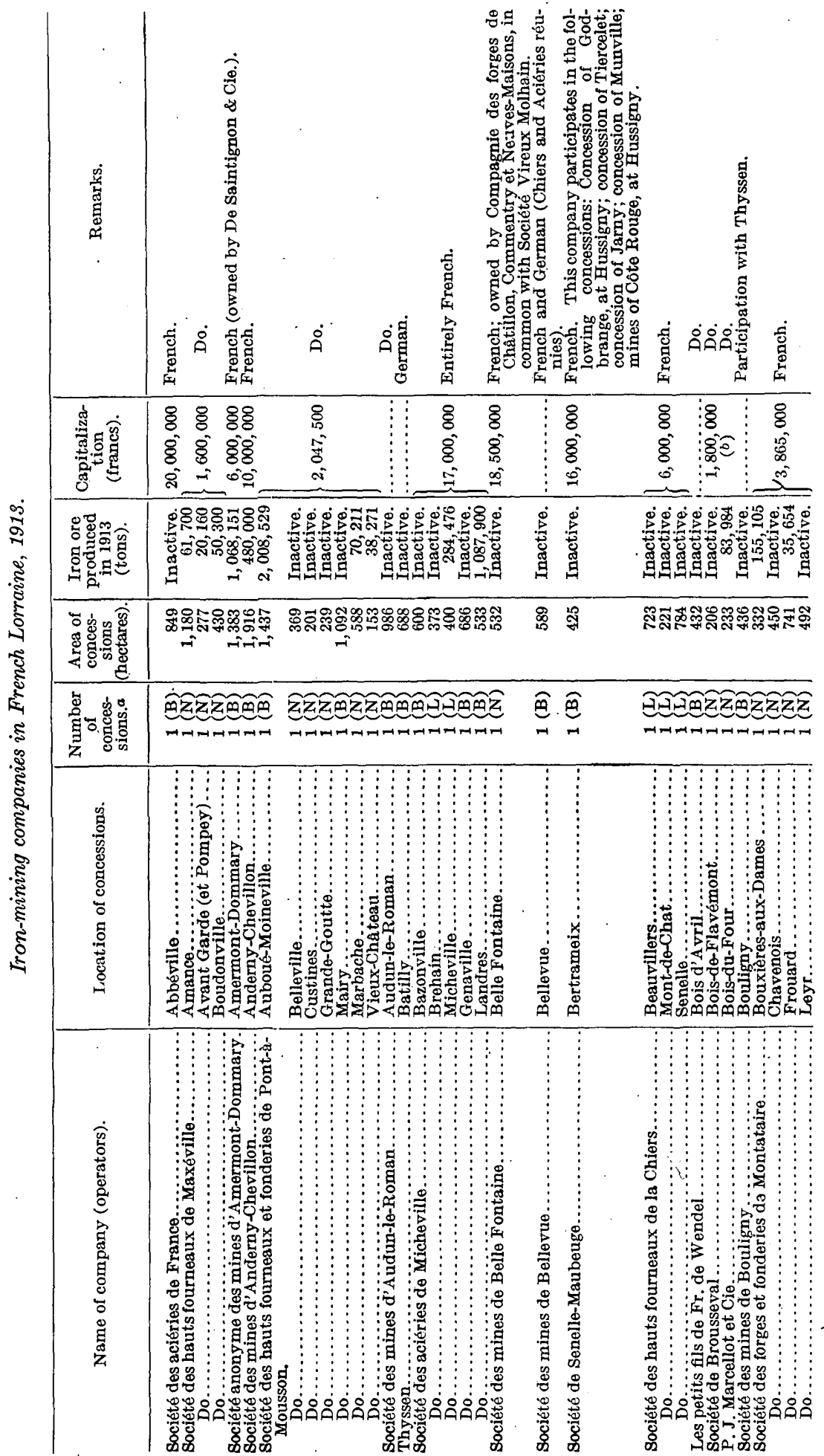




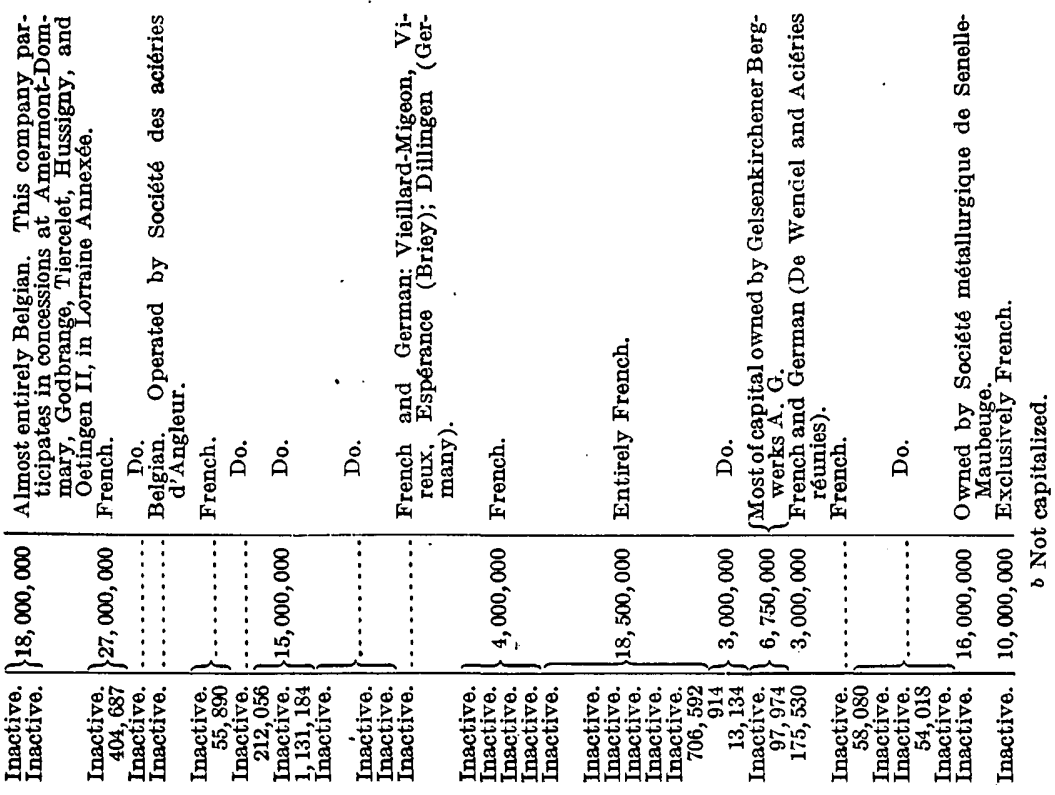

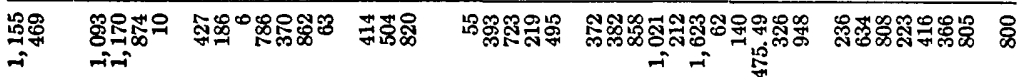

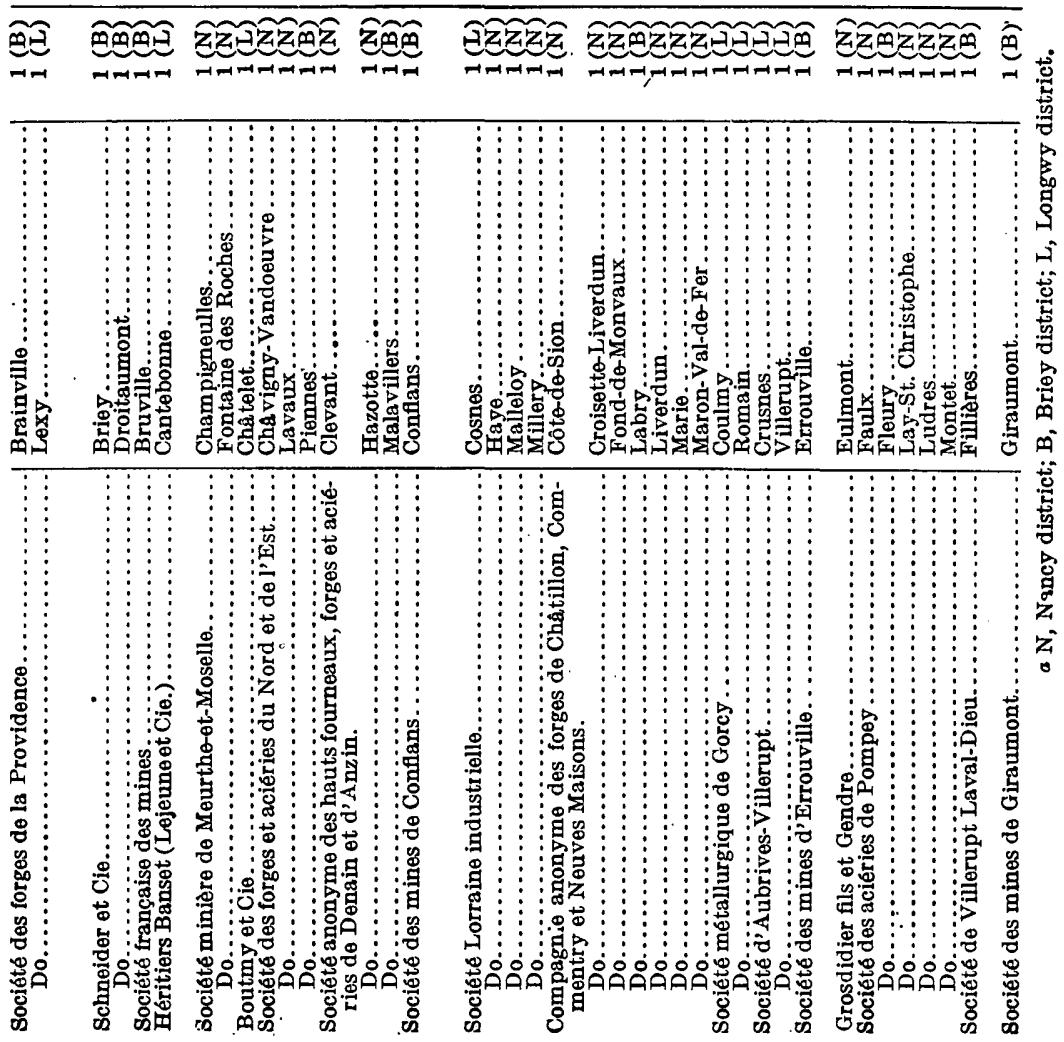


46 IRON AND ASSOCIATED INDUSTRIES OF LORRAINE, ETC.

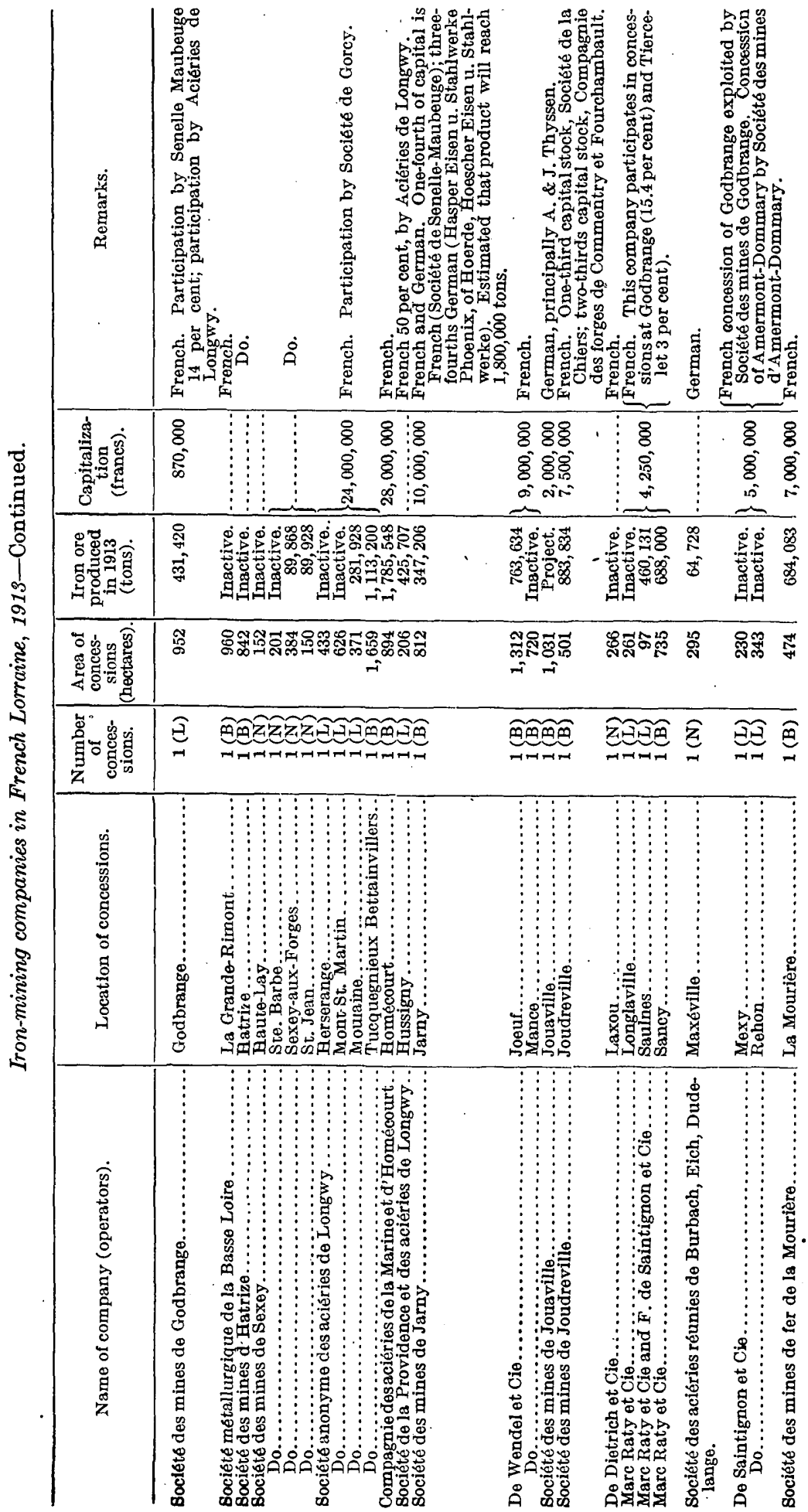




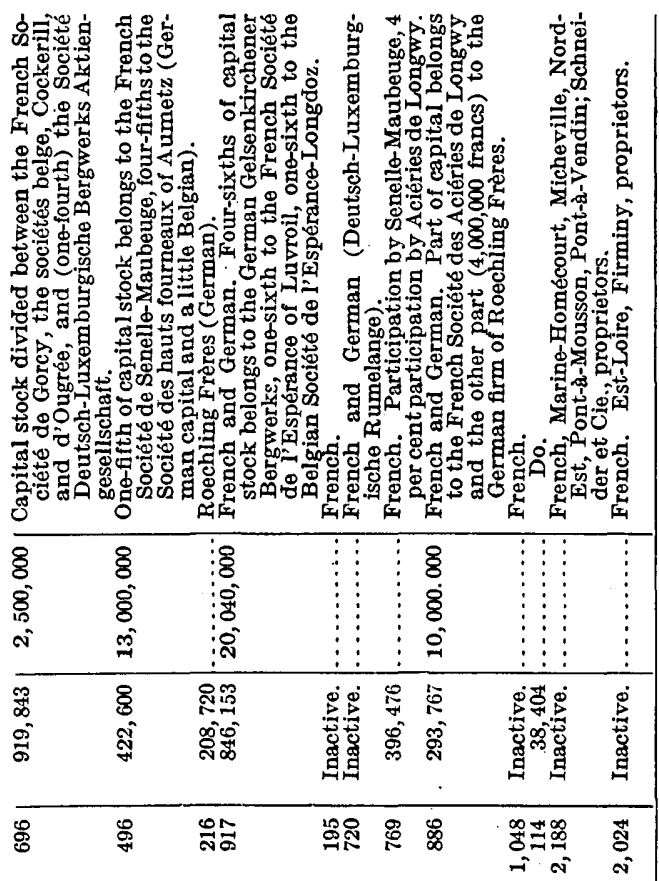

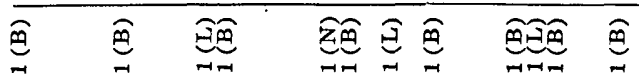

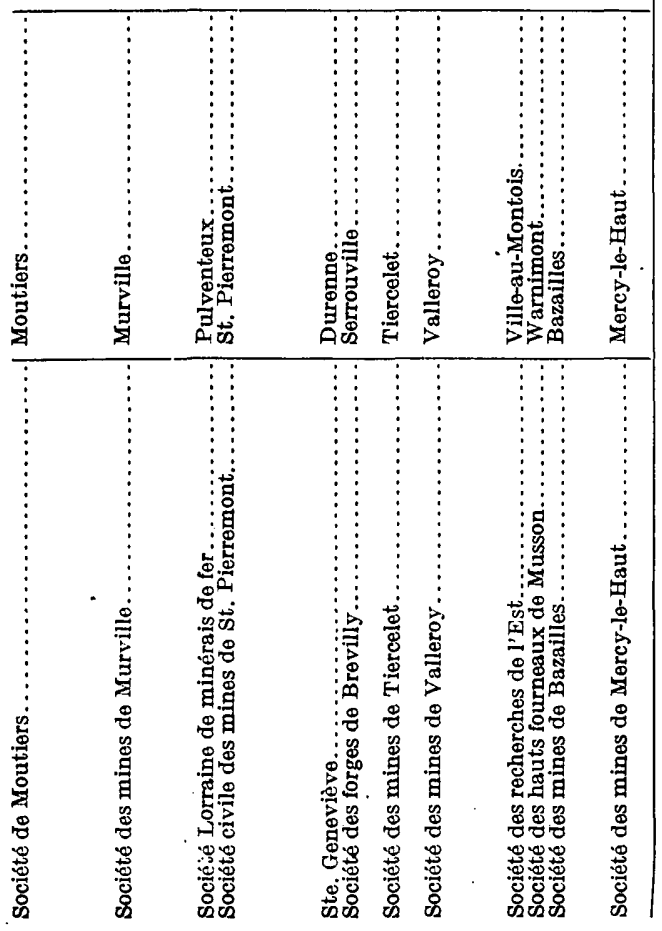


Summary of concessions of iron lands in French Lorraine, 1918.

\begin{tabular}{|c|c|c|c|c|c|c|}
\hline \multirow[b]{2}{*}{ District. } & \multicolumn{3}{|c|}{ Number of concessions. } & \multirow{2}{*}{$\begin{array}{c}\text { Total } \\
\text { area of } \\
\text { active } \\
\text { and idle } \\
\text { conces- } \\
\text { sions (hec- } \\
\text { tares). }\end{array}$} & \multirow{2}{*}{$\begin{array}{l}\text { Production } \\
\text { of iron ore } \\
\text { (tons). }\end{array}$} & \multirow{2}{*}{$\begin{array}{l}\text { Total capi- } \\
\text { talization } \\
\text { (francs). }\end{array}$} \\
\hline & Active. & Inactive. & Total. & & & \\
\hline \multirow[t]{2}{*}{ 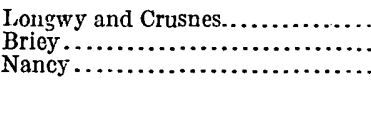 } & $\begin{array}{l}11 \\
12 \\
22\end{array}$ & $\begin{array}{l}13 \\
41 \\
13\end{array}$ & $\begin{array}{l}24 \\
53 \\
35\end{array}$ & $\begin{array}{l}12,596 \\
43,019 \\
11,991\end{array}$ & $\begin{array}{r}3,727,157 \\
14,891,749 \\
1,370,709\end{array}$ & $\begin{array}{r}43,620,000 \\
298,767,500 \\
23,865,000\end{array}$ \\
\hline & 45 & 67 & 112 & 67,606 & $19,989,615$ & $a 366,252,500$ \\
\hline
\end{tabular}

$a$ Not complete.

French and Belgian ownership of iron lands in French Lorraine, 1913.

\begin{tabular}{|c|c|c|c|c|c|c|c|c|}
\hline \multirow[b]{2}{*}{ District. } & \multicolumn{4}{|c|}{$\begin{array}{l}\text { Companies whose ownership is entirely } \\
\text { French. }\end{array}$} & \multicolumn{4}{|c|}{$\begin{array}{c}\text { Companies whose ownership is entirely } \\
\text { Belgian. }\end{array}$} \\
\hline & $\begin{array}{c}\text { Num- } \\
\text { ber. }\end{array}$ & $\begin{array}{c}\text { A rea of } \\
\text { conces- } \\
\text { sions(hec- } \\
\text { tares). }\end{array}$ & $\begin{array}{c}\text { Production } \\
\text { (tons). }\end{array}$ & $\begin{array}{l}\text { Capitaliza- } \\
\text { tion } \\
\text { (franes). }\end{array}$ & $\begin{array}{c}\text { Num- } \\
\text { ber. }\end{array}$ & $\begin{array}{c}\text { Area of } \\
\text { conces- } \\
\text { sions(hec- } \\
\text { tares). }\end{array}$ & $\begin{array}{l}\text { Produc- } \\
\text { tion } \\
\text { (tons). }\end{array}$ & $\begin{array}{l}\text { Capitali- } \\
\text { zation } \\
\text { (francs). }\end{array}$ \\
\hline \multirow[t]{2}{*}{$\begin{array}{l}\text { Longwy and Crusnes. } \\
\text { Briey ................... } \\
\text { Nancy } . . \cdots \cdots \ldots \ldots \ldots\end{array}$} & $\begin{array}{r}11 \\
29 \\
5\end{array}$ & $\begin{array}{l}15,182 \\
33,810 \\
12,424\end{array}$ & $\begin{array}{l}2,046,114 \\
7,441,335 \\
1,305,981\end{array}$ & $\begin{array}{r}18,870,000 \\
239,097,500 \\
23,865,000\end{array}$ & $\begin{array}{l}2 \\
0 \\
0\end{array}$ & $\mid \begin{array}{r}1,165 \\
\cdots \cdots \cdots \cdots \\
\cdots \cdots \cdots\end{array}$ & Inactive. & $\begin{array}{l}a \quad 18,000,000 \\
a 18,000,000 \\
\cdots \ldots \ldots \ldots \ldots\end{array}$ \\
\hline & 45 & 61,416 & $10,793,430$ & $281,832,500$ & 2 & 1,165 & $\cdots$ & $a 36,000,000$ \\
\hline
\end{tabular}

$a$ In part.

German ownership of iron lands in French Lorraine, 1913.

\begin{tabular}{l|r|r|r|r|r|r|r}
\hline \multirow{2}{*}{ Distrint. } & \multicolumn{3}{|c|}{$\begin{array}{c}\text { Companies whose ownership is French } \\
\text { and German. }\end{array}$} & \multicolumn{2}{c}{ Companies whose ownership is entireiy } \\
German.
\end{tabular}

a In part. 
FRENCH LORRAINE.

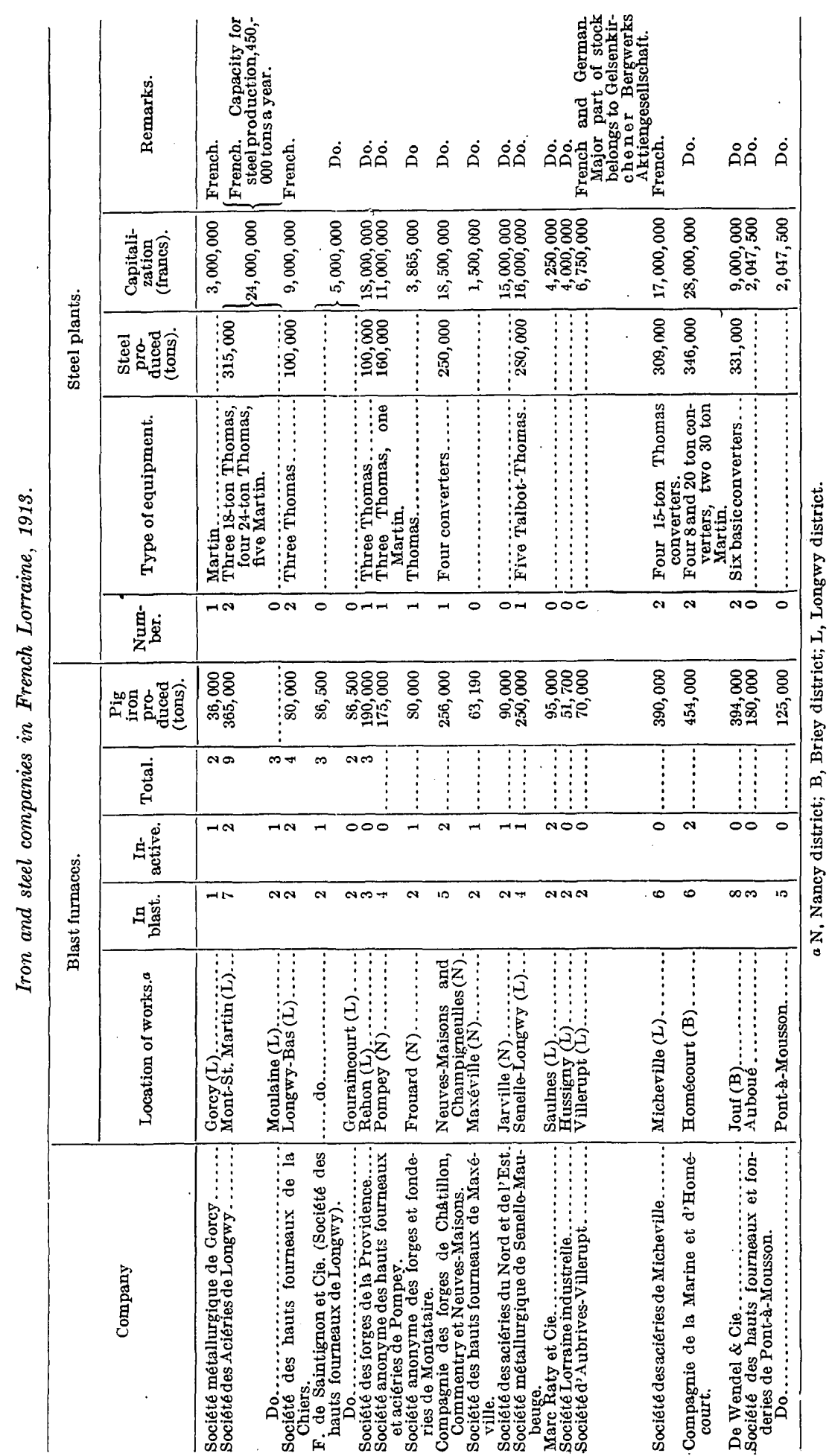

$187234^{\circ}-20-B u 11.703-4$ 
Summary of iron and steel plants in French Lorraine, 1913.

\begin{tabular}{|c|c|c|c|c|c|c|}
\hline \multirow[b]{2}{*}{ District. } & \multicolumn{4}{|c|}{ Blast furnaces. } & \multicolumn{2}{|c|}{ Steel plants. } \\
\hline & In blast. & Inactive. & Total. & $\begin{array}{l}\text { Pig iron } \\
\text { produced } \\
\text { (tons). }\end{array}$ & Number. & $\begin{array}{l}\text { Raw steel } \\
\text { produced } \\
\text { (tons). }\end{array}$ \\
\hline $\begin{array}{l}\text { Longwy and Crusnes. } \\
\text { Briey } \ldots \ldots \ldots \ldots \ldots \ldots \\
\text { Nancy } \ldots \ldots \ldots \ldots \ldots \ldots\end{array}$ & $\begin{array}{l}35 \\
17 \\
20\end{array}$ & $\begin{array}{r}10 \\
2 \\
5\end{array}$ & $\begin{array}{l}45 \\
19 \\
25\end{array}$ & $\begin{array}{r}1,700,700 \\
1,028,000 \\
789,190\end{array}$ & $\begin{array}{l}8 \\
4 \\
3\end{array}$ & $\begin{array}{r}a 1,104,000 \\
677,000 \\
410,000\end{array}$ \\
\hline & 72 & 17 & 89 & $3,517,890$ & $\cdot 15$ & $2,191,000$ \\
\hline
\end{tabular}

a Incomplete.

Note. $-\Lambda$ ll the companies are French owned except the Société d'Aubrives-Villerupt, most of the stock of which is owned by the Geisenkirchener Bergwerks Aktiengesellschaft (German).

So far as known the only metallurgic company controlled by German capital is the Société d'Aubrives-Villerupt. This company owns two furnaces in the Longwy district and 800 hectares of iron lands. The value of the iron lands is discussed below; the pre-war value of the furnaces was $2,000,000$ and $3,000,000$ francs.

According to the above tables five German companies own 2,343 hectares of iron lands in French Lorraine, ten companies of mixed French and German capital own 15,535 hectares, and two Belgian companies own 1,165 hectares.

On the assumption that in the companies of mixed capitalization the Germans' interests represent only half of the total, the German ownership in Lorraine iron-ore land would be about 10,000 hectares, or 14 per cent of the entire field. It is probably conservative to place a value of 100,000,000 francs on German holdings in French Lorraine.

The invasion of French Lorraine by German capital is of comparatively recent date. It is the result of German recognition of the fact that a continuation of the growth of the Westphalian iron and steel industry depended on a supply of ore from the French fields. This fact has been recorded in German technical publications, which point out that the Westphalian iron and steel companies by 1910 had already provided for the future by securing control of over 6,000 hectares of iron lands in French Lorraine.

\section{LORRAINE ANNEXÉE.}

By Alfred H. Brooks.

\section{INTRODUCTION.}

The iron mines of Lorraine Annexée in 1913 produced 75 per cent of the iron-ore output of the German Empire, and their reserves then constituted 47 per cent of Germany's total. In capacity the Lorraine furnaces and steel plants are second only to those of Westphalia. The iron ores of Lorraine Annexée can be shipped by water 
grade down the Moselle Valley to the Rhine and to the Westphalian coal fields, and they are in easy communication with the Sarre coal field. It is this geographic position that gave them under the prewar conditions an even far greater importance than the above-stated percentages of reserves would seem to indicate.

The iron lands are owned by about 44 corporations and individuals, but, as will be shown below, a few strong companies hold the larger part of the field. Of these, 11 are furnace and steel companies operating plants.

The total capitalization of the companies owning iron lands, mines, furnaces, and steel plants in Lorraine Annexée is over 1,400,000,000 francs. This figure, however, gives no measure of the value of their holdings in the district, for many of these companies have large financial interests in iron lands, furnaces, and steel plants in other regions. A rough estimate indicates that the total value of their holdings in Lorraine Annexée is 1,191,000,000 francs. It is estimated that the gross value of the product of the mines, furnaces, and raw steel plants of Lorraine Annexée in 1913 was about 700,000,000 francs, and the total profits about $80,000,000$ francs.

\section{IRON-ORE DEPOSITS.}

The iron ores are similar to those of French Lorraine and occur in beds dipping to the west and ranging in thickness from 2 to 6 meters. (See Pl. I.) In most places there is only one bed of workable ore, but in some places there are two or three or even four beds. The ore is oolitic limonite carrying from 26 to 40 per cent of iron and 1.5 to 2 per cent of phosphorus. In the southern part of the field the ore is siliceous, carrying 8.15 per cent of silica; in the northern part it is calcareous, carrying 8 to 20 per cent of lime. This fact makes it possible to obtain a good mixture for blast furnaces by using the proper proportions in different parts of the field.

The average percentage of iron in the run of mine product is gradually decreasing, as the poorer grades of ore are being drawn upon. In 1901 the average was about 36 per cent of iron, in 1907 it was 32 per cent, and in 1913 it was probably about 30 per cent.

The iron-ore reserves of Lorraine Annexée are estimated to aggregate $1,830,000,000$ tons. Of this quantity about $400,000,000$ is siliceous and the rest calcareous. The total area of the concessions, which probably include all the iron-ore deposits, is 43,000 hectares.

\section{CONCESSIONS.}

The iron lands of Lorraine Annexée have been granted as concessions on the same general principles as those of French Lorraine, already described. Many of these concessions antedate the Treaty of Frankfort, and hence were made under the old French law. The 
Germans have modified the law, however, by limiting the size of a single concession to 200 hectares, but as these could be sold, the restriction has not prevented the consolidation of the small concessions into large holdings.

The law of 1908 provides not only that taxes should be assessed on profits but that they should be based on the estimated capacity of production of each mine. The purpose of this provision appears to have been to force development. The total taxes in 1910 ranged from 7.2 to 15 centimes a ton, in accordance with the capacity of the mines. The ownership of the iron lands will be discussed in a later section.

\section{MINING.}

Much the greater part of the ore occurs in beds outcropping on the valley slopes and hence can be mined by adits. Part of it, however, lies deep and must be recovered by shafts. The shafts average about 200 meters in depth, the deepest being 250 meters deep.

Most of the readily accessible ore near the surface available for recovery by open pits has been exhausted, and this form of mining is on the decline. The percentages of total recovery by different methods of mining are as follows: Adits, 70 per cent; shafts, 28.5 per cent; open pits, 1.5 per cent.

The cost of mining varies greatly, according to local conditions. In the adit mines the investments are small, which makes the amortization very low; in the deep mines (200 meters) the amortization is about 1.25 francs to the ton. Except for the cost of pumping there is no great difference between the cost of shaft and adit mines. The average costs for 1909 are reported as follows:

Cost per ton of iron mining in Lorraine Annexée, 1909.

\begin{tabular}{|c|c|}
\hline Labor. . & $\begin{array}{c}\text { Francs. } \\
1.08-1.56\end{array}$ \\
\hline Haulage... & $.12-.36$ \\
\hline Timbers... & $.06-.36$ \\
\hline Coal. . & $.06-.18$ \\
\hline Sorting and grading. & $.06-.12$ \\
\hline Material.............. & $.24-.48$ \\
\hline Miner's insurance...$\ldots \ldots \ldots \ldots \ldots \ldots \ldots$ & $.10-.14$ \\
\hline 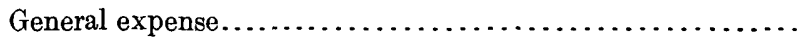 & $.12-.24$ \\
\hline Taxes.............................................. & $.06-.15$ \\
\hline 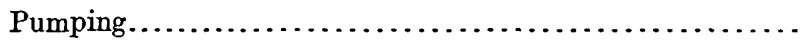 & .60 \\
\hline
\end{tabular}

Including charges for amortization and exhaustion of ore the total costs will be 2.40 to 3.60 francs to the ton for adit mining and 3 to 4.10 francs for shaft mining. Though there are no exact figures available it is probable that the average cost of mining is about 3 francs to the ton, or about 70 centimes less than the average for French Lorraine. 
In 191355 iron mines were operated in Lorraine Annexée. These mines employed 15,642 men and produced $21,136,000$ tons of ore.

The average wages in Lorraine Annexée in 1909 were 7.33 francs a day for miners, 5.05 francs for helpers, and 4.83 francs for surface men. The average annual recovery per employee was about 1,100 tons. In 1913 the average output of iron ore per mine was 450,000 tons.

Lorraine Annexée is one of the oldest iron-mining districts of Europe. Its large development, like that of French Lorraine and

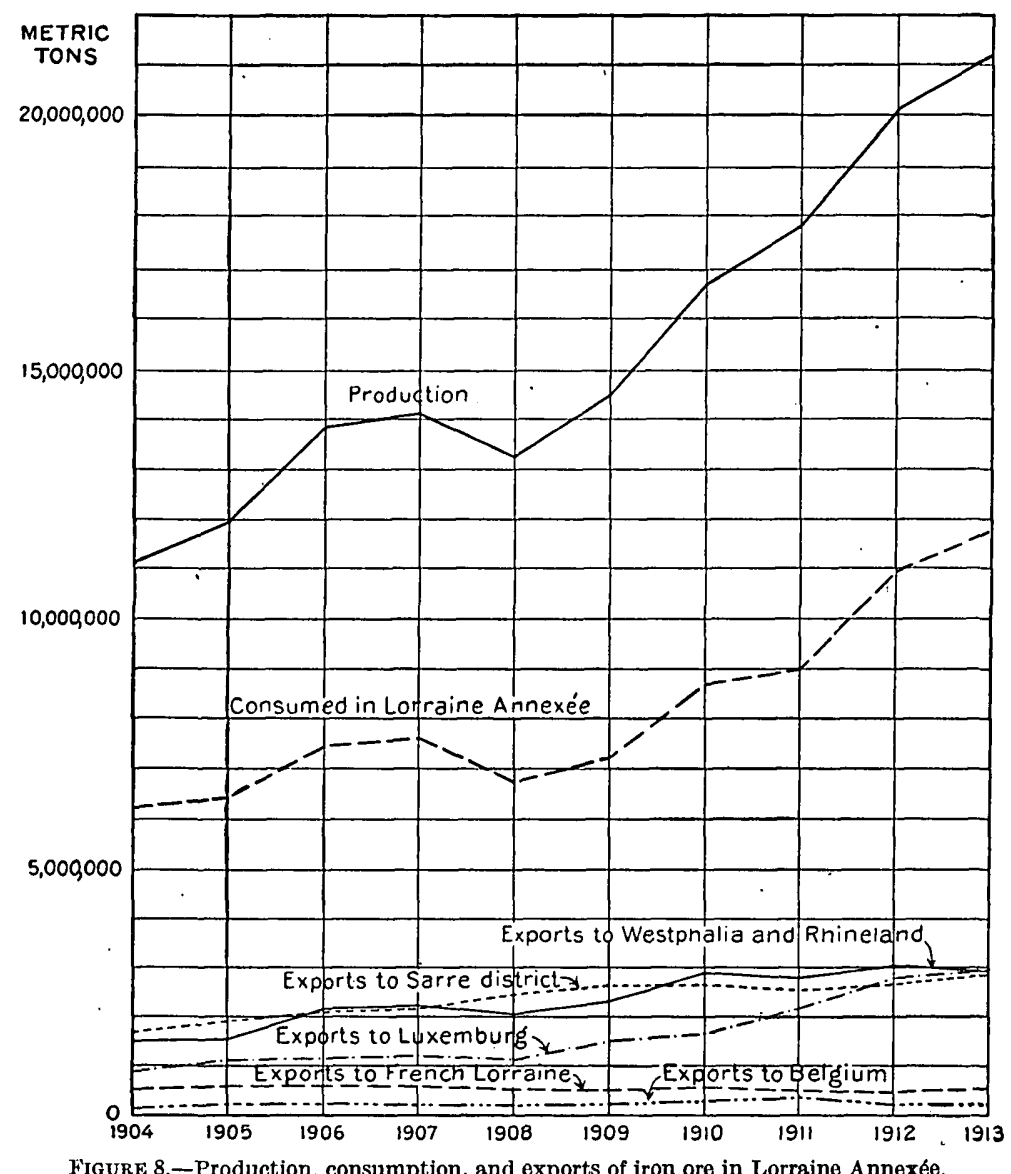

Luxemburg, dates from the time of the introduction of the basic process of making steel (1880), which rendered it possible to use ores of high phosphorus content. The accompanying diagram (fig. 8) and table show the production and place of utilization of the iron ores from the district. Westphalia draws heavily on Lorraine Annexée, and the Sarre district is almost entirely supplied from that source. There have also been large shipments into Luxemburg. All these shipments go by rail except those to Westphalia, to which small lots are sent by canal by way of Strasbourg and the Rhine Valley. 
Iron ore produced in Lorraine Annexée and consumed in different countries, 1904-1913, in tons.

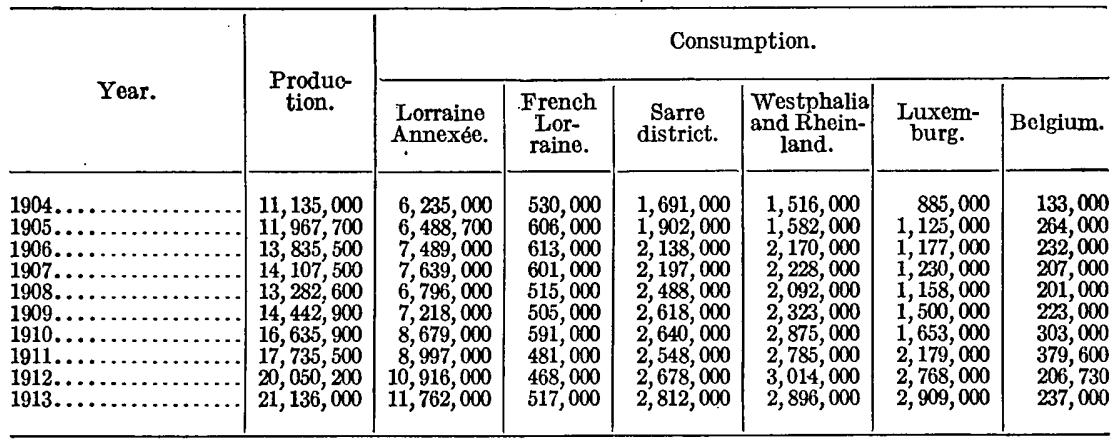

PRODUCTION OF PIG IRON AND STEEL.

Lorraine Annexée in 1913 produced 22 per cent of the pig iron and 13 per cent of the steel of the German Empire. The total production in 1913 included 3,870,000 tons of pig iron, 2,286,350 tons of steel, and about 500,000 tons of semifinished and finished products. In 1913 there were 51 blast furnaces operated in Lorraine Annexée, having a total daily capacity of about 13,000 tons. The district contains nine steel plants, of which seven were operated in 1913, having a total of 26 Bessemer basic converters (capacity 12 to 35 tons) and 12 Martin furnaces (capacity 25 to 30 tons). There were also in the district two puddling works, three rolling mills, two wire mills, and eleven cast-iron and steel foundries.

The metallurgic plants of Lorraine Annexée consumed about $5,300,000$ tons of coke in 1913. Of this about $1,500,000$ tons came from the near-by Sarre coal field and 3,800,000 tons from Westphalia and Aix-la-Chapelle. In addition to the coke the mining and metallurgic industry of Lorraine Annexée probably consumed about $1,000,000$ tons of Sarre coal. Reducing the above-stated coke consumption to coal, we find that the. Sarre district furnished only about 50 per cent of the fuel used by the mining and metallurgic industries of Lorraine Annexée.

Iron ore consumed and pig iron and steel produced in Lorraine Annexée, 1904-1913, in tons.

\begin{tabular}{|c|c|c|c|c|c|}
\hline \multirow[b]{2}{*}{ Year. } & \multicolumn{2}{|c|}{ Iron ore consumed. } & \multirow[b]{2}{*}{$\begin{array}{l}\text { Pig iron } \\
\text { produced. }\end{array}$} & \multirow{2}{*}{$\begin{array}{l}\text { Pig iron } \\
\text { shipped to } \\
\text { Westphalia } \\
\text { and other } \\
\text { German } \\
\text { districts. }\end{array}$} & \multirow[b]{2}{*}{$\begin{array}{c}\text { Steel } \\
\text { produced. }\end{array}$} \\
\hline & $\begin{array}{c}\text { From } \\
\text { Lorraine } \\
\text { Annexée. }\end{array}$ & $\begin{array}{c}\text { From } \\
\text { French } \\
\text { Lorraine } \\
\text { (approxi- } \\
\text { mate). }\end{array}$ & & & \\
\hline $\begin{array}{l}1904 \ldots \ldots \\
1905 \ldots \ldots \ldots \\
1906 \ldots \ldots \\
1907 \ldots \ldots \\
1908 \ldots \ldots \\
1909 \ldots \ldots \\
1910 \ldots \ldots \\
1911 \ldots \ldots \\
1912 \ldots \ldots\end{array}$ & $\begin{array}{r}6,235,000 \\
6,488,000 \\
7,489,000 \\
7,639,000 \\
6,796,000 \\
7,218,000 \\
8,679,000 \\
8,997,000 \\
10,916,000 \\
11,762,000\end{array}$ & $\begin{array}{r}78,000 \\
66,000 \\
184,000 \\
251,000 \\
250,000 \\
280,000 \\
250,000 \\
425,000 \\
450,000 \\
814,000\end{array}$ & $\begin{array}{l}2,070,100 \\
2,168,800 \\
2,422,500 \\
2,511,600 \\
2,182,200 \\
2,314,700 \\
2,722,500 \\
2,935,300 \\
3,463,800 \\
3,869,870\end{array}$ & $\begin{array}{l}1,093,290 \\
1,062,880 \\
1,199,409 \\
1,308,238 \\
1,114,721 \\
1,196,389 \\
1,543,036 \\
1,692,514 \\
1,600,000 \\
1,583,516\end{array}$ & $\begin{array}{r}976,810 \\
1,105,920 \\
1,223,091 \\
1,203,362 \\
1,067,479 \\
1,118,311 \\
1,179,464 \\
1,242,786 \\
1,790,000 \\
2,286,354\end{array}$ \\
\hline
\end{tabular}


OWNERSHIP OF IRON ILANDS AND METALLURGIC PLANTS.

The ownership of iron mines and metallurgic plants in Lorraine Annexée in 1913, so far as determined, is shown in the subjoined tables. The 11 furnaces and steel companies operating in the district in 1913 owned 20,500 hectares (48 per cent) of the iron lands, and the mines operated on these lands produced 67 per cent of the total output of the district. Practically all the rest of the ore mined in 1913 was taken from mines owned by metallurgic companies whose plants were in other districts. There was, therefore, in 1913 no ore mined in Lorraine Annexée that was sold in the open market. The iron and steel companies of Westphalia, the Sarre, and other outside districts own about 12,500 hectares in Lorraine Annexée, and therefore a total of 33,000 hectares of iron land, which amounts to 80 per cent of the total area, is owned by the local and foreign iron and steel companies. The ownership of the rest of the iron lands is divided among small corporations and individuals, only a part of which are listed here.

The details in regard to the ownership of lands, furnaces, and steel plants are shown in the following tables, which include the arailable data in regard to the capitalization of the corporations and the ownership of iron lands and metallurgic plants:

Capitalization of companies operating blast furnaces, steel plants, and mines in Lorraine Annexée, 1913.

\begin{tabular}{|c|c|c|}
\hline Name of company. & $\begin{array}{l}\text { Capitalize- } \\
\text { tion } \\
\text { (francs) }\end{array}$ & Remarks. \\
\hline GERMAN. & & \\
\hline $\begin{array}{l}\text { Gelsenkirchener Bergwerks } \Lambda \text {. G. (Abt. } \\
\text { Aachener Hütten-Verein). }\end{array}$ & & $\begin{array}{l}\text { Value of plants of the Audun. le Tiche divi- } \\
\text { sion estimated at } 8,830,878 \text { marks. }\end{array}$ \\
\hline $\begin{array}{l}\text { Rombacher Hüttenwerke... } \\
\text { Sociétédes hauts fournoaux do Rumelango- } \\
\text { St. Ingbert. }\end{array}$ & $\begin{array}{r}62,500,000 \\
7,500,000\end{array}$ & $\begin{array}{l}\text { Rented and exploited by the Deutsch-Lux- } \\
\text { emburgische Bergwerks A. G., which owns } \\
\text { a portion of its capital stock. }\end{array}$ \\
\hline Deutsch-Luxemburgische Bergwerks A.G.: & $162,500,000$ & $\begin{array}{l}\text { This company owns } 37,500,000 \text { francs of tho } \\
\text { capital stock of the } \$ \text { ociété anonymo des } \\
\text { hauts fourneaux et aciéries de Rumelange- } \\
\text { St. Ingbert. }\end{array}$ \\
\hline Société Lothringen Eisenwerke. & $4,000,000$ & Since its liquidation is a subsidiary of Thys- \\
\hline $\begin{array}{l}\text { Bochumer Verein für Bergbau u. Gussstahl- } \\
\text { fabrikation. }\end{array}$ & $45,000,000$ & \\
\hline Eschweiler Bergwerks-Verein............ & $47,500,000$ & Owns an interest in the Vereinigten Hütten- \\
\hline $\begin{array}{l}\text { Dillinger Hüttenwerke A. G .............. } \\
\text { Roechlingische Eisen u. Stahlwerke G. } \\
\text { m. b. H. }\end{array}$ & $21,100,000$ & \\
\hline 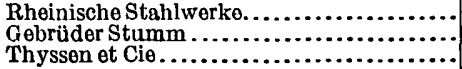 & $\begin{array}{r}75,000,000 \\
21,600,000 \\
1,250,000\end{array}$ & The mine Mosel I is owned by a Thyssen \\
\hline . & & $\begin{array}{l}\text { subsidiary The Société Lothringen Eisen- } \\
\text { werke d'Ars. Maringen is owned by the } \\
\text { Société des mines de Marange (Sambre-et- } \\
\text { Moselle) but is exploited by Thysen. } \\
\text { Most of Thyssen stock is in hands of the } \\
\text { Société Deutsches Kaiser A. G. }\end{array}$ \\
\hline 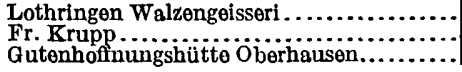 & $\begin{array}{r}2,500,000 \\
312,000,000 \\
40,000,000\end{array}$ & Owned by Peipers \& Co., of Siegen. \\
\hline
\end{tabular}


Capitalization of companies operating blast furnaces, steel plants, and mines in Lorraine Annexée, 1913-Continued.

Name of company.
GERMAN-cont nued.
Lothringen Hüttenverein Aumetz-Friede
(Hauts fourneaux Lorraine Aumetz la
(Hauts$$
\text { G }
$$

Phoenix A. G. Hoerde

Gewerkschaft Fameck.

Carl Spalter ot Cie., Coblenz.

Héritiers de Humbert.

Quinter Eisen-Hütte.

einbollerhütte) .......

Montangesellschaft.

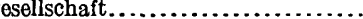

Lothringen-Saar-Gewerkschaft Vincent.....

Rudolph Bocking et Cio., Brebach.

Gewerkschaft Lessy.

rry

Jahiet, Gerand, Lamotte et Cie...............

Laval

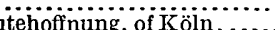

R. Böcking and Dillinger Hiuttenwerke.

Gebrüder Stumm and Dillinger Hütten-

werke.
Phoenix, Gutehoffnungshütte.

Total German (incomplete)

$1,229,275,000$

FRENCH.

Sociétémétallurgiqued'Aubrives-Villerupt. Do Wendel et Cie. (Les petits fils de Fr. de Wendel).

Charles Barat.

Laboulle et Francois

Total French (incomplete)

BELGIAN.

Société anonyme d'Ougrée-Marihaye....... Fentscher Hütten A. G.

Société de Monceau-St. Fiacre.

Total Belgian

(a)

$30,000,000$

(a)

$72,500,000$

In liquidation; $1,172,911$ francs of capital stock was German owned prior to liquidation. Company now German owned. The Lothringen Hütten und Bergwerko Verein A. G., of Nilvingen, was owned by this company and with it is in process of liquidation. It was capitalized at $58,000,000$

$132,500,000$

(a)

(a)

(a)

$2,575,000$

(a)

(a)

(a)

(a)

(a)

(a)

$6,250,000$

....................

$\ldots$

35 companies in the district. Those marked "No data" hold inactive mining concessions. Those left blank own concessionsin cooperation.
FRENCH, BELGIAN, AND LUXEMBURGIAN.

Aciéries réunies de Burbach, Eich, Dudolange.

Ougrée, Athus, Providence.

Sociétémétallurgique deSambre-et-Moselle

Les petits fils de Fr. de Wendel et Aciéries réunies Burbach, Eich, Dudelange.

Total French, Belgian, and Luxemburgian.

Grand total.

$83,500,000$

$1,401,625,000$

$60,000,00 n$

$23,500,000$
Three companies in the district.

$52,725,000$

$6,000,000$

$61,850,000$

Belgian, French, and German participation. German stock predominates in this Belgian company; Société anonyme de Montigniessur-Sambre has an interest.

French, Belgian, Luxemburgian, and a very small part German.

Four companies mixed capitalization in the district.

Forty-four companies in all operate steel plants, blast furnaces, and mines, and own iron lands in Lorraine Annexée.

$a$ No data. 
Ownership and production of iron lands and mines, blast furnaces, and steel plants in Lorraine Annexée, 1913.

\begin{tabular}{|c|c|c|c|c|c|c|c|}
\hline \multirow{2}{*}{ Name of company. } & \multicolumn{2}{|c|}{ Mineral lands. } & \multicolumn{3}{|c|}{ ' Blast furnaces. } & \multicolumn{2}{|c|}{ Steel plants. } \\
\hline & Area. & $\begin{array}{c}\text { Iron ore } \\
\text { produced. }\end{array}$ & $\begin{array}{l}\text { Number } \\
\text { in blast. }\end{array}$ & $\begin{array}{c}\text { Total } \\
\text { number. }\end{array}$ & $\begin{array}{c}\text { pig iron } \\
\text { produced. }\end{array}$ & $\begin{array}{c}\text { Num- } \\
\text { ber. }\end{array}$ & $\begin{array}{c}\text { Steel } \\
\text { produced. }\end{array}$ \\
\hline GERMAN. & & & & & & & \\
\hline 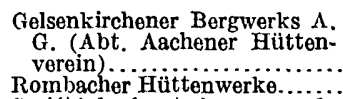 & $\begin{array}{r}\text { Hectares. } \\
1,545 \\
2,643\end{array}$ & $\begin{array}{l}\text { Tons. } \\
2,678,500 \\
2,269,500\end{array}$ & $\begin{array}{r}4 \\
11\end{array}$ & 4 & $\begin{array}{c}\text { Tons. } \\
760,000 \\
466,800\end{array}$ & $\begin{array}{l}1 \\
2\end{array}$ & $\begin{array}{l}\text { Tons. } \\
972,400\end{array}$ \\
\hline Société des hauts fourneaux de & & & & & & & \\
\hline $\begin{array}{l}\text { Rumelange-St. Ingbert........ } \\
\text { Deutsch-Luxemburgische Berg- }\end{array}$ & 101 & 544,000 & 2 & 3 & 62,750 & 1 & 153,600 \\
\hline 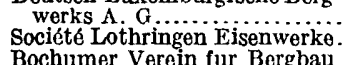 & $\begin{array}{r}292 \\
0\end{array}$ & $\begin{array}{l}0 \\
0\end{array}$ & $\begin{array}{l}3 \\
0\end{array}$ & $\begin{array}{l}3 \\
3\end{array}$ & $\begin{array}{r}95,250 \\
0\end{array}$ & $\begin{array}{l}0 \\
0\end{array}$ & $\begin{array}{l}0 \\
0\end{array}$ \\
\hline $\begin{array}{l}\text { Bochumer Verein fur B } \\
\text { u. Gussstahlfabrikatio }\end{array}$ & 203 & 763,700 & 0 & 0 & 0 & 0 & 0 \\
\hline Eschweiler Berg & 282 & 169,263 & 0 & 0 & 0 & 0 & 0 \\
\hline $\begin{array}{l}\text { Dillinger Hüttenwerke } A . \text { G } \\
\text { Roechlingisch } \theta \text { Eisen } \mathrm{u} \text {. Stahl- }\end{array}$ & 692 & 247,600 & 3 & 3 & 57,857 & 0 & 0 \\
\hline werke G. m. b. H............. & 1,349 & $1,379,600$ & 4 & 4 & 179,500 & 0 & 0 \\
\hline he Stahlwerke... & 553 & 491,103 & 0 & 0 & & 0 & 0 \\
\hline Gebrüder S & 1,109 & 464,000 & 6 & 6 & 195,750 & 0 & 0 \\
\hline Thyssen et Cie. & 1,969 & $1,134,400$ & 9 & 9 & 528,800 & 1 & (a) \\
\hline Fr.Krupp............................ & 781 & 421,700 & 0 & 0 & & 0 & 0 \\
\hline 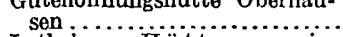 & 36 & 123,400 & 0 & 0 & 0 & 0 & 0 \\
\hline $\begin{array}{l}\text { Lothringen Hütt onverein } \\
\text { Aumetz-Friede. }\end{array}$ & & & & & & & \\
\hline $\begin{array}{l}\text { Aumetz-Friede, } \\
\text { Phoenix (Hoerde) } \mathrm{H} \text { os ch, }\end{array}$ & 981 & $1,659,100$ & 9 & 10 & 255,000 & 1 & 594,254 \\
\hline Klockner... & 643 & 811,600 & 0 & 0 & 0 & 0 & 0 \\
\hline Gower & 192 & & 0 & 0 & 0 & 0 & 0 \\
\hline of Coblenz.. & 753 & 0 & 0 & 0 & 0 & 0 & 0 \\
\hline Hériti & 130 & 0 & 0 & 0 & 0 & 0 & 0 \\
\hline Quinter Eisen-Huitte................... & 370 & 0 & 0 & 0 & 0 & 0 & 0 \\
\hline $\begin{array}{l}\text { Gebrüder Puricelli (Rhein- } \\
\text { bollerhütte).................. }\end{array}$ & 300 & 0 & 0 & 0 & 0 & 0 & \\
\hline Rhoinische Baugeselischait..... & 200 & 0 & 0 & 0 & 0 & 0 & 0 \\
\hline Lothringen- & & & & & & & \\
\hline 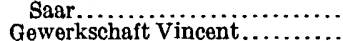 & $\begin{array}{l}767 \\
172\end{array}$ & $\begin{array}{l}0 \\
0\end{array}$ & $\begin{array}{l}0 \\
0\end{array}$ & $\begin{array}{l}0 \\
0\end{array}$ & $\begin{array}{l}0 \\
0\end{array}$ & $\begin{array}{l}0 \\
0\end{array}$ & $\begin{array}{l}0 \\
0\end{array}$ \\
\hline et Cie., of & & & & & & & \\
\hline Bre & 505 & 0 & 0 & 0 & 0 & 0 & \\
\hline Gewer & 198 & 0 & 0 & 0 & 0 & 0 & 0 \\
\hline Vve. & 150 & 0 & $\begin{array}{l}0 \\
0\end{array}$ & $\begin{array}{l}0 \\
0\end{array}$ & $\begin{array}{l}0 \\
0\end{array}$ & 0 & 0 \\
\hline Gewerkschaft Ar & 461 & 0 & 0 & $\begin{array}{l}0 \\
0\end{array}$ & . & & 0 \\
\hline 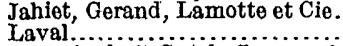 & $\begin{array}{l}170 \\
303\end{array}$ & $\begin{array}{l}0 \\
0\end{array}$ & 0 & $\begin{array}{l}0 \\
0\end{array}$ & 0 & $\begin{array}{l}0 \\
0\end{array}$ & U \\
\hline Gewerkschaft Gutehoffnung, of & 55 & 0 & 0 & 0 & 0 & 0 & 0 \\
\hline$R$. Bocking and Dillinger & 55 & 0 & 0 & 0 & & & 0 \\
\hline $\begin{array}{l}\text { Hüttenwerke........ Dillinger } \\
\text { Gebrider Stumm and }\end{array}$ & 888 & 675,300 & 0 & 0 & 0 & 0 & 0 \\
\hline 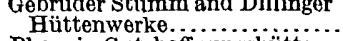 & 1,017 & 98 & 0 & 0 & 0 & 0 & 0 \\
\hline Phoenix Gut & 3,722 & 859,000 & 0 & 0 & 0 & 0 & 0 \\
\hline Total German. . & 23,532 & $15,681,200$ & 51 & 53 & $2,811,600$ & 6 & $2,286,100$ \\
\hline FRENCH. & & & & & & & \\
\hline $\begin{array}{l}\text { Société métallurgique } \\
\text { d'Aubrives-Villerupt............ }\end{array}$ & 129 & 44,000 & 0 & 0 & 0 & 0 & 0 \\
\hline $\begin{array}{l}\text { De Wendel et Cie. (Les petits } \\
\text { fils de Fr. de Wendel)......... }\end{array}$ & 6,350 & $2,825,600$ & 17 & 20 & 698,800 & 3 & (a) \\
\hline Charles Barat & 20 & 0 & 0 & $\begin{array}{r}0 \\
0\end{array}$ & 0 & 0 & $\stackrel{0}{0}$ \\
\hline Laboulle et & & & 0 & 0 & 0 & 0 & \\
\hline Total French. & 6,502 & $2,869,600$ & 17 & 20 & 698,800 & 3 & 0 \\
\hline - BELGIAN. & & & & & & & \\
\hline $\begin{array}{l}\text { Société anonyme d'Ougrée- } \\
\text { Marihaye. } \ldots \ldots \ldots \ldots \ldots \ldots \ldots \ldots\end{array}$ & 199 & 0 & $\mathbf{0}$ & 0 & 0 & 0 & \\
\hline $\begin{array}{l}\text { Fentscher Hütten A. G........ } \\
\text { Société de Monceau-St. Fiacre.. }\end{array}$ & $\begin{array}{r}354 \\
86\end{array}$ & 133,000 & $\begin{array}{l}2 \\
0\end{array}$ & $\begin{array}{l}3 \\
0\end{array}$ & $\begin{array}{r}227,500 \\
0\end{array}$ & $\begin{array}{l}0 \\
0\end{array}$ & $\begin{array}{l}0 \\
0\end{array}$ \\
\hline Total Belgian. & 639 & 133,000 & 2 & 3 & 227,500 & 0 & 0 \\
\hline
\end{tabular}

a No data. 
Ownership and production of iron lands and mines, blast furnaces, and steel plants in Lorraine Annexée, 1913-Continued.

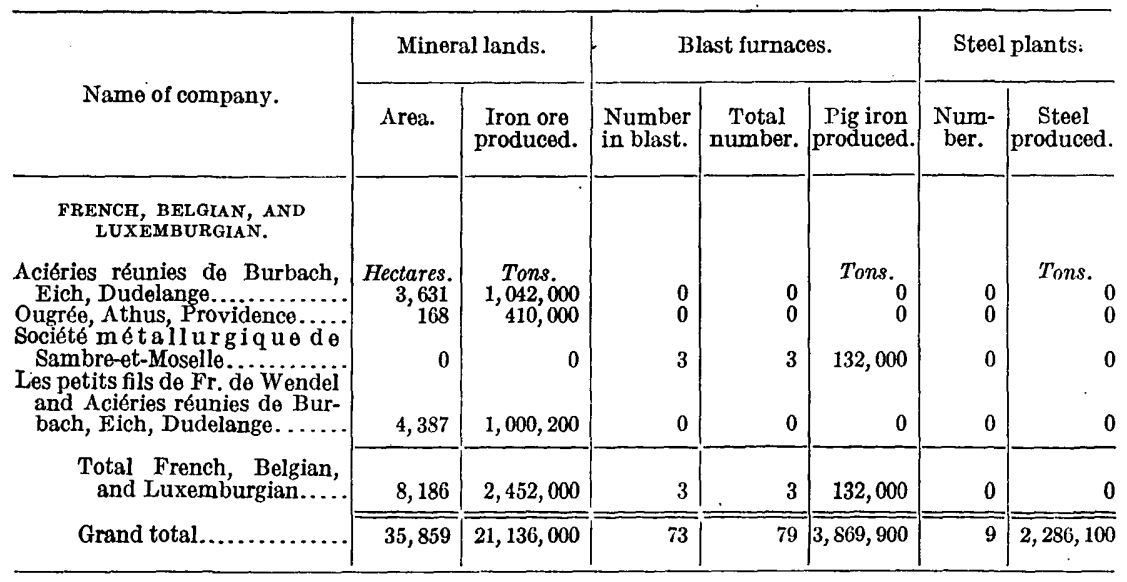

From the above tables it will be seen that the lands, mines, and metallurgic plants are owned by corporations whose capital is either German, French, Belgian, or mixed French and Belgian.

A rough estimate indicates that the total capital invested in mining equipment, furnaces, and steel plants is between $800,000,000$ and $850,000,000$ francs. The value of the iron lands and mines is estimated to be between $250,000,000$ and $400,000,000$ francs. With these figures as a basis, the approximate value of the aggregate holdings of the corporations, classed according to the sources of their capital, is shown in the subjoined table. This table does not include the value of the plants engaged in making special kinds of iron and steel and semifinished and finished products. These are all of German ownership, and their value is probably between 5,000;000 and $10,000,000$ francs.

Estimated value of iron lands, mines, furnaces, and steel plants in Lorraine Annexée, 1913 , in francs.

\begin{tabular}{|c|c|c|c|}
\hline Source of capital. & $\begin{array}{l}\text { Iron lands } \\
\text { and mines. }\end{array}$ & $\begin{array}{c}\text { Furnaces } \\
\text { and steel } \\
\text { plants. }\end{array}$ & Total. \\
\hline \multirow[t]{2}{*}{ 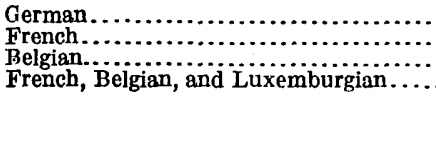 } & $\begin{array}{r}250,000,000 \\
51,000,000 \\
4,000,000 \\
65,000,000\end{array}$ & $\begin{array}{r}700,000,000 \\
100,000,000 \\
13,000,000 \\
8,000,000\end{array}$ & $\begin{array}{r}950,000,000 \\
151,000,000 \\
17,000,000 \\
73,000,000\end{array}$ \\
\hline & $370,000,000$ & $821,000,000$ & $1,191,000,000$ \\
\hline
\end{tabular}




\section{LUXEMBURG.}

By Alfred H. Brooks and Morris F. LA Crolx.

\section{INTRODUCTION.}

The metallurgy of iron and steel and the associated mining and manufacturing represent the largest and most valuable part of the industries of Luxemburg.

In 1913 the total capitalization of the six companies operating iron-ore mines, blast furnaces, and steel plants was $518,800,000$ francs. This capitalization represents a figure in excess of the total value of the iron lands and iron and steel plants in Luxemburg, as it necessarily includes holdings in subsidiary iron-ore companies and coal and coke companies, the latter located principally in the Westphalian district. It is estimated that the total value of the Luxemburg ore lands and iron and steel plants in 1913 was $414,000,000$ francs, of which $265,000,000$ francs, or 64 per cent, was owned or controlled by German interests.

The iron ore produced in 1913 was $7,333,372$ tons, valued at $35,000,000$ francs. Of this amount 60 per cent, or $4,424,850$ tons, was smelted in Luxemburg furnaces, yielding 2,547,900 tons of pig iron, valued at 190,000,000 francs. Approximately 50 per cent of the domestic pig was refined into 1,182,226 tons of crude steel, valued at $112,000,000$ francs. 'The gross value of the iron ore, pig iron, and crude steel produced in 1913 was approximately $220,800,000$ francs. The total profit realized on these products is estimated at $35,000,000$ francs.

The iron and steel industry practically doubled its production between the end of 1908 and the outbreak of the war, thus paralleling the similar development in the iron and steel producing districts of Lorraine, Belgium, and Germany.

The location of the iron and steel metallurgic plants in Luxemburg and their subsequent expansion during the pre-war decade is due to the following conditions: The close juxtaposition of siliceous and calcareous iron ores, providing a self-fluxing ore mixture for the blast furnaces; a favorable location of the metallurgic plants with respect to the Briey iron-ore district, in French Lorraine, which provided a richer iron ore to supplement the domestic ores; the favorable location of the Belgian (Haine-Sambre-Meuse) and Westphalian coal districts; and the good systems of connecting rail transportation. It should also be noted that Luxemburg was within the German Customs Union and enjoyed its privileges and that a large part of the iron and steel produced was controlled and handled by the Stahlwerks Verband, the growth and prosperity of the Luxemburg steel and iron industry being thus closely identified with that of the Rhine Valley. 


\section{OCCURRENCE OF IRON ORE.}

The iron ore of the Luxemburg part of the Lorraine field occurs in two basins separated by a fault. The western basin called the Differdange Basin, contains only siliceous ores, which carry from 28 to 41 per cent of iron. The other, called the Rumelange Basin, contains only calcareous ores, which carry from 17 to 27 per cent of iron. The phosphorus contents of these ores is 1 per cent or less.

\section{IRON-ORE RESERVES.}

The iron lands include 3,672 hectares, which were estimated to contain at the end of $1909270,000,000$ tons of ore averaging 33 per cent of iron. Between 1909 and the end of 1912 about 25,000,000 tons was mined. In 19121,600 hectares of iron lands had been mined out. This left at the end of 1912 about 2,000 hectares of iron lands, containing $245,000,000$ tons of ore. The ore output of this field has not fluctuated greatly during the last decade. At the average rate of production the reserves will last about 35 years.

\section{IRON-LAND CONCESSIONS.}

Since 1870 the iron lands have been leased in concessions of varying size. At that date the titles of the proprietors of land on which surface mines had already been opened, including 1,560 hectares, were confirmed, with a provision that they should pay 2 per cent annually on the value of the land to the Government. Furnace owners were also granted 764 hectares on condition that the land should not be alienated and that the ore mined should be smelted in Luxemburg. Three railroad grants have been made, aggregating in all 702 hectares, and it appears that these concessions were made without limitations as to sale or use of ore. In 1913 concessions were granted for the remaining 582 hectares of iron-ore lands to four furnace companies under a 50-year lease, with an annual rental averaging 2,243 francs a hectare. These leases provide that the ore is to be smelted and refined in Luxemburg and that the lessees are to furnish the Luxemburg Government with 17 metric tons per hectare of 75 per cent ground Thomas furnace slag containing not less than 16 per cent of phosphoric acid (85 per cent to be soluble in 2 per cent citric acid). The concessionnaires are to receive 21 francs a ton for the slag. The Luxemburg Government now receives an annual income of about $1,874,000$ francs from its iron concessions. The following tables summarize the available information on the iron concessions: 
Concessions of iron land in Luxemburg.

\begin{tabular}{|c|c|c|}
\hline : & $\begin{array}{l}\text { Area } \\
\text { (hec- } \\
\text { tares). }\end{array}$ & Annual rencal. \\
\hline \multirow[t]{2}{*}{ 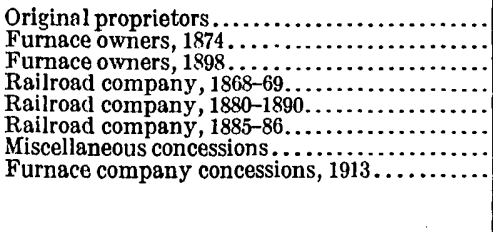 } & $\begin{array}{r}1,560 \\
406 \\
347 \\
417 \\
142 \\
145 \\
78 \\
582\end{array}$ & \multirow[t]{2}{*}{$\begin{array}{l}2 \text { per cent on value of land. } \\
750 \text { francs per hectare. } \\
800 \text { francs per hectare. } \\
(?) \\
\text { ?) } \\
(?) \\
(?) \\
2,243 \text { francs per hectare. }\end{array}$} \\
\hline & 3,677 & \\
\hline
\end{tabular}

Sale price of iron-ore concessions in Luxemburg, 1904-1912, in francs per hectare.

\begin{tabular}{|c|c|c|c|}
\hline Year. & $\begin{array}{l}\text { Basin of Esch- } \\
\text { Rumelange- } \\
\text { Dudelange, left } \\
\text { bank (calca- } \\
\text { reous ore). }\end{array}$ & $\begin{array}{l}\text { Basin of Differ- } \\
\text { dange - Pétange } \\
\text { (siliceous ore). }\end{array}$ & $\begin{array}{l}\text { Basin of Dude- } \\
\text { lange, right bank } \\
\text { (calcareous ore). }\end{array}$ \\
\hline 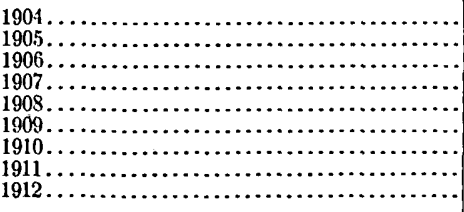 & $\begin{array}{r}15,200 \\
35,193 \\
31,216 \\
13,925 \\
16,100 \\
18,000 \\
36,855 \\
36 . . .\end{array}$ & 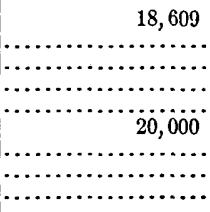 & 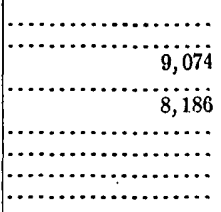 \\
\hline Average...... & 23,784 & 19,304 & 8,630 \\
\hline
\end{tabular}

The following two tables show the ownership of the furnace companies working in Luxemburg iron ores. The five furnace and steel companies control $225,206,000$ tons of the total estimated reserves of 240,000,000 tons. Furthermore, these company holdings include the best and most accessible of the iron-ore deposits. The German control of the iron lands will be considered in a later section of this report.

Approximate tonnage of iron ore controlled by furnace companies in Luxemburg, 1911.

\begin{tabular}{|c|c|c|c|c|}
\hline Company. & $\begin{array}{c}\text { Calcareous } \\
\text { ore. }\end{array}$ & $\begin{array}{l}\text { Siliceous } \\
\text { ore. }\end{array}$ & Total. & Capital. \\
\hline $\begin{array}{l}\text { Hütten u. Stahlwerk von Steinfort........... } \\
\text { Deutsch-Luxemburgische Bergwerks u. Hiut- }\end{array}$ & $\begin{array}{r}10,507,000 \\
7,146,000\end{array}$ & $11,448,000$ & $\begin{array}{l}10,507,000 \\
18,594,000\end{array}$ & \multirow{5}{*}{$\begin{array}{l}\text { German. } \\
\text { Do. } \\
\text { Do. } \\
\text { Do. } \\
\text { Mixed, one-ninth } \\
\text { German. } \\
\text { Belgian. }\end{array}$} \\
\hline $\begin{array}{l}\text { ten A. G. } \\
\text { Gelsenkirchener Bergwerks } A . G \ldots \ldots \ldots \ldots \\
\text { Rumelangen u. St. Ingbert Hochofen u. }\end{array}$ & $\begin{array}{r}13,639,000 \\
8,545,000\end{array}$ & $1,380,000$ & $\begin{array}{r}13,639,000 \\
9,925,000\end{array}$ & \\
\hline $\begin{array}{l}\text { Stahlwerk A. G. } \\
\text { Société de Burbach, Eich, Dudelange.......... }\end{array}$ & $46,29 \dot{5}, 000$ & $12,140,000$ & $58,435,000$ & \\
\hline \multirow[t]{2}{*}{ Société anonyme d'Ougrée-Marihaye.......... } & $5,956,000$ & $6,274,000$ & $12,230,000$ & \\
\hline & $92,088,000$ & $31,242,000$ & $123,330,000$ & \\
\hline
\end{tabular}


Approximate tonnage of iron ore acquired by furnace companies in Luxemburg, 1918.

\begin{tabular}{|c|c|c|c|c|c|c|}
\hline \multirow{2}{*}{ Company. } & \multicolumn{2}{|c|}{$\begin{array}{l}\text { Total ares of } 1913 \\
\text { concessions (hec- } \\
\text { tares). }\end{array}$} & \multirow{2}{*}{$\begin{array}{l}\text { Calcareous } \\
\text { ore (tons). }\end{array}$} & \multirow{2}{*}{$\begin{array}{c}\text { Siliceous } \\
\text { ore (tons). } \\
\\
\end{array}$} & \multirow{2}{*}{$\begin{array}{l}\text { Total } \\
\text { (tons). }\end{array}$} & \multirow{2}{*}{ Capital. } \\
\hline & $\begin{array}{l}\text { Calcare- } \\
\text { ous. }\end{array}$ & $\begin{array}{l}\text { Sili- } \\
\text { ceous. }\end{array}$ & & & & \\
\hline $\begin{array}{l}\text { Hütten u. Stahlwerk von } \\
\text { Steinfort. } \\
\text { Deu ts ch-Luxemburg- } \\
\text { ische Bergwerks u. } \\
\text { Hütten A. G. } \\
\text { Gelsenkirchener Berg- } \\
\text { werks A.G. } \\
\text { Rumelangen u. St. Ing- } \\
\text { bert Hochofen u. Stahl- } \\
\text { werk A. G. } \\
\text { Société de Burbach, } \\
\text { Eich, Dudelange. } \\
\text { Société anonyme d' } \\
\text { Ougrée-Marihaye. }\end{array}$ & $\begin{array}{l}60 \\
79\end{array}$ & $\begin{array}{r}65 \\
245\end{array}$ & $\begin{array}{r}12,780,000 \\
13,035,000 \\
8,131,000\end{array}$ & \begin{tabular}{|l}
$14,805,000$ \\
$67,930,500$ \\
$31,242,000$ \\
$99,172,500$
\end{tabular} & $\begin{array}{r}23,030,000 \\
55,910,000 \\
8,131,000\end{array}$ & $\begin{array}{l}\text { German. } \\
\text { Do. } \\
\text { Do. } \\
\text { Do. } \\
\text { Mixed, one-ninth } \\
\text { German. } \\
\text { Belgian. }\end{array}$ \\
\hline
\end{tabular}

IRON MINING.

In 1870 the Luxemburg iron fields produced 911,000 tons of ore. The output steadily increased and in 1874 was almost 4,000,000 tons. It attained the peak in 1907, when it was more than $7,490,000$ tons. This figure was approximated by a production of $7,331,000$ tons in 1913. The larger percentage of this output was mined by companies subsidiary to the six large iron and steel producers. There were, however, a number of small iron-ore mining companies that produced an appreciable tonnage of ore, chiefly for export.

About 5,500 men were employed in the iron-mining industry in 1911, at an average wage of 1.73 francs per ton mined.

The output of 1913 came from 95 mines, of which 43 ware deep and 52 open pits. It is probably safe to estimate that 60 to 70 per cent of the ore came from open-pit mines. The individual mine production is not known, but the following table shows the ownership of the operated mines:

Ownership of iron mines in Luxemburg, 1918.

\begin{tabular}{|c|c|c|c|}
\hline Ownership. & $\begin{array}{l}\text { Deep } \\
\text { mines. }\end{array}$ & $\begin{array}{l}\text { Open-pit } \\
\text { mines. }\end{array}$ & Total. \\
\hline \multirow[t]{2}{*}{ 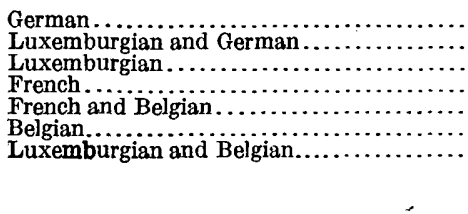 } & $\begin{array}{r}13 \\
5 \\
12 \\
3 \\
1 \\
9\end{array}$ & $\begin{array}{r}13 \\
5 \\
20 \\
1 \\
12 \\
12 \\
1\end{array}$ & $\begin{array}{r}26 \\
10 \\
32 \\
4 \\
1 \\
21 \\
1\end{array}$ \\
\hline & 43 & 52 & 95 \\
\hline
\end{tabular}


During the pre-war decade Luxemburg exported a large percentage of her iron ore. The subjoined tables show the production and distribution of this ore. During this period the exportation of iron ore to French Lorraine decreased by more than 50 per cent, and the exports to Belgium, which have always been about half of the total exports, showed a slight decrease, but the exports to Germany increased. Restrictions have been placed on the exportation of iron ores from certain concessions, which will have the effect of cutting down exports sometime before the exhaustion of the present reserves.

Distribution of Luxemburg iron ore in 1913.

\begin{tabular}{|c|c|c|}
\hline Smelted in- & Per cent. & Tons. \\
\hline \multirow[t]{2}{*}{ 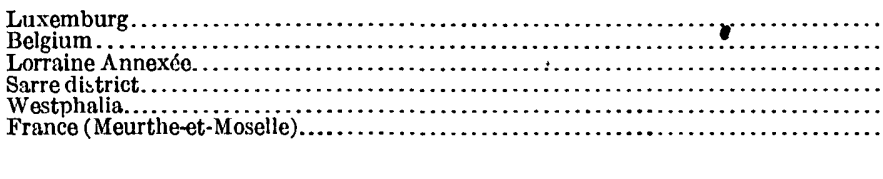 } & \multirow[t]{2}{*}{\begin{tabular}{r|}
60.3 \\
20.0 \\
3.8 \\
3.4 \\
7.4 \\
5.1
\end{tabular}} & $\begin{array}{r}4,425,000 \\
1,471,000 \\
279,000 \\
240,000 \\
542,000 \\
376,000\end{array}$ \\
\hline & & $7,333,000$ \\
\hline
\end{tabular}

Iron ore produced in Luxemburg and consumed in different countries, 1904-191s, in tons.

\begin{tabular}{|c|c|c|c|c|c|c|c|}
\hline \multirow[b]{2}{*}{ Year. } & \multirow[b]{2}{*}{ Production. } & \multicolumn{6}{|c|}{ - Consumption. } \\
\hline & & $\begin{array}{l}\text { Lorraine } \\
\text { Annexée. }\end{array}$ & $\begin{array}{c}\text { French } \\
\text { Lorraine. }\end{array}$ & $\begin{array}{c}\text { Sarre } \\
\text { district. }\end{array}$ & $\begin{array}{l}\text { Westpha- } \\
\text { lia and } \\
\text { Rhein- } \\
\text { land. }\end{array}$ & Belgium. & $\begin{array}{l}\text { Luxem- } \\
\text { burg. }\end{array}$ \\
\hline 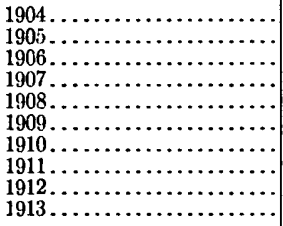 & $\begin{array}{l}6,347,800 \\
6,595,900 \\
7,229,400 \\
7,491,000 \\
5,801,000 \\
5,794,000 \\
6,263,000 \\
6,060,000 \\
6,533,900 \\
7,331,050\end{array}$ & $\begin{array}{l}184,000 \\
255,000 \\
319,000 \\
354,000 \\
225,000 \\
132,000 \\
193,000 \\
214,000 \\
180,000 \\
278,760\end{array}$ & $\begin{array}{l}888,000 \\
940,000 \\
841,000 \\
846,000 \\
499,000 \\
395,000 \\
377,000 \\
350,000 \\
367,200 \\
375,400\end{array}$ & $\begin{array}{l}103,000 \\
245,000 \\
221,000 \\
241,000 \\
283,000 \\
278,000 \\
318,000 \\
371,000 \\
351,500 \\
240,240\end{array}$ & $\begin{array}{l}286,000 \\
270,000 \\
483,000 \\
580,000 \\
400,000 \\
371,000 \\
554,000 \\
502,000 \\
526,000 \\
541,350\end{array}$ & $\begin{array}{l}1,821,000 \\
1,829,000 \\
2,026,000 \\
2,259,000 \\
1,759,000 \\
1,625,000 \\
1,519,000 \\
1,318,000 \\
1,294,600 \\
1,470,450\end{array}$ & $\begin{array}{l}2,931,000 \\
3,166,000 \\
3,417,000 \\
3,211,000 \\
2,635,000 \\
2,993,000 \\
3,302,000 \\
3,305,000 \\
3,813,700 \\
4,424,850\end{array}$ \\
\hline
\end{tabular}

COST OF MINING IRON ORE.

The cost of mining the Luxemburg iron ores in 1911 are reported to be a.s follows: Open-pit mines, 2.10 to 2.50 francs per ton; underground mines, 2.20 to 2.70 francs per ton. The costs were divided as follows and do not include royalties, amortization of plant, or interest on capital.

Distribution of cost of mining iron ore in Luxemburg, 1911.

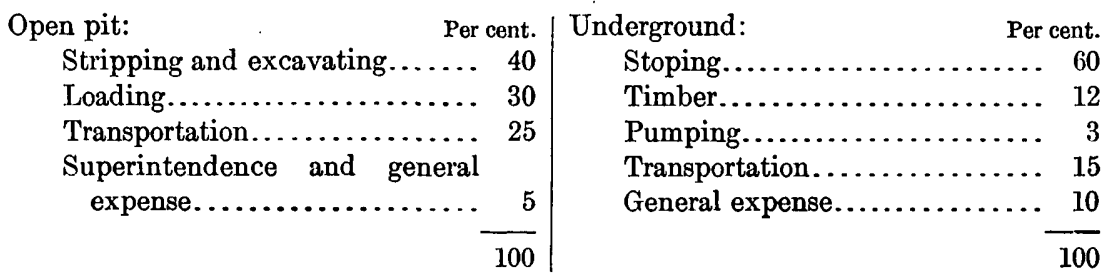


An additional charge of 0.50 to 0.80 franc per ton should be added to cover royalties, amortization, and interest on capital. This expense is not given in the published reports on the cost of producing the iron ore but is charged to the final cost of the finished product by the iron and steel companies that control the mining companies.

The prices of ore in 1911 were as follows: Calcareous ore, 3.288 francs per ton $\mathrm{f}$. o. b. ; siliceous ore, 2.800 francs per ton $\mathrm{f}$. o. b. The $6,059,797$ tons of ore mined during 1911 were valued at 3.08 francs per ton. This figure represents the book value of the ore placed on it by the iron and steel companies that control the production of the mines.

Mining companies operating in France near the Luxemburg frontier sold on the market ore having a content of 34 to 40 per cent of iron for 3.75 francs per ton. Ores having the same iron content, but especially desirable for "mixing," sold as high as 4.75 francs per ton.

The above facts in production cósts and value of the iron ore can be summarized as follows:

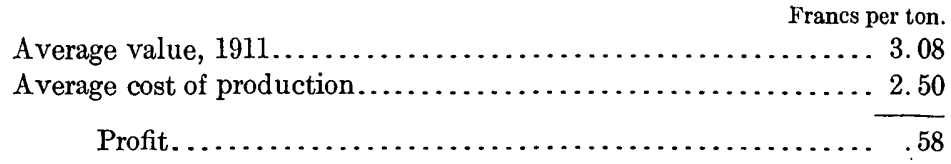

This profit represents approximately the additional cost due to royalties, amortization, and interest. Therefore the average value of 3.08 francs per ton placed on the ore by the iron and steel manufacturers closely approximates the total cost to these companies.

Using the market price obtained for the corresponding French ores the following profits are shown:

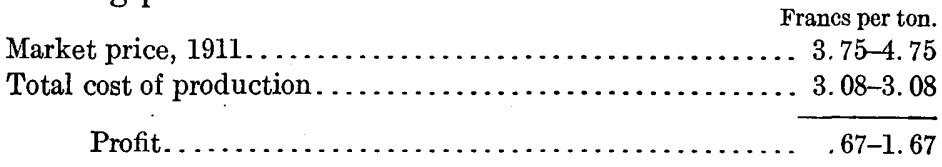

It is therefore estimated that the actual profit on Luxemburg ore in 1911 was about 0.85 franc per ton.

BLAST FURNACES.

Six companies operated 34 blast furnaces in Luxemburg in 1910. Within three years this number was increased to 46 , having a tcital daily capacity of $7,420,000$ tons of pig iron. About 65 per cent of this capacity was controlled by German interests, as will be shown later in this report.

The total number of men employed in the blast.furnaces was about 6,000 , earning wages amounting to 3.68 francs pei ton of pig iron.

The following tables show the impcrts and total consumption of iron ore and the pig iron and steel produced in Luxemburg during the years 1904 to 1913, inclusive. The importation of iron ore from French 
Lorraine increased thirteenfold and that from Lorraine Annexée nearly fourfold during this period. The consumption of domestic ores did not double. The increase in the percentage of imported ores used in the Luxemburg furnaces was due in part to the higher grade of the ores produced in the Briey district (French Lorraine), and to the ownership of iron-ore concessions in Lorraine Annexée by the German-controlled iron and steel companies. The Luxemburg furnaces used chiefly Westphalian coal and coke, with some from Belgium. The imports of coke in 1913 were 2,686,000 tons from Westphalia and 200,000 tons from Belgium, a total of 2,886,000 tons.

Iron ore consumed and pig iron and steel produced in Luxemburg, 1904-191s, in tons.

\begin{tabular}{|c|c|c|c|c|c|c|}
\hline \multirow{2}{*}{ Year. } & \multirow{2}{*}{$\begin{array}{l}\text { Iuxem- } \\
\text { burg iron } \\
\text { ore con- } \\
\text { sumed. }\end{array}$} & \multicolumn{2}{|c|}{ Iron ore imported. } & \multirow{2}{*}{$\begin{array}{l}\text { Total iron } \\
\text { ore con- } \\
\text { sumed. }\end{array}$} & \multirow{2}{*}{$\begin{array}{c}\text { Pig iron } \\
\text { produced. }\end{array}$} & \multirow{2}{*}{$\begin{array}{l}\text { Steel pro- } \\
\text { duced. }\end{array}$} \\
\hline & & $\begin{array}{c}\text { French } \\
\text { Jotraine. }\end{array}$ & $\begin{array}{l}\text { Lorraine } \\
\text { Annexét. }\end{array}$ & & & \\
\hline $\begin{array}{l}1904 \ldots \ldots \ldots \\
1900 \ldots \ldots \ldots \\
1906 \ldots \ldots \ldots \\
1907 \ldots \ldots \ldots \\
1908 \ldots \ldots \ldots \\
1909 \ldots \ldots \ldots \\
1910 \ldots \ldots \ldots \\
1911 \ldots \ldots \ldots \ldots \\
1912 \ldots \ldots \ldots \ldots \\
1913 \ldots \ldots \ldots \ldots\end{array}$ & $\begin{array}{l}2,931,000 \\
3,166,000 \\
3,417,000 \\
3,211,000 \\
2,635,000 \\
2,993,000 \\
3,302,000 \\
3,305,000 \\
\mathbf{3}, 413,700 \\
\mathbf{4}, 424,850\end{array}$ & $\begin{array}{r}92,000 \\
164,000 \\
166,000 \\
251,000 \\
281,000 \\
389,000 \\
447,000 \\
349,000 \\
627,100 \\
1,201,350\end{array}$ & $\begin{array}{r}885,000 \\
1,125,000 \\
1,177,000 \\
1,230,000 \\
1,158,000 \\
1,500,000 \\
1,653,000 \\
2,179,700 \\
2,768,000 \\
3,380,000\end{array}$ & $\begin{array}{l}3,908,000 \\
4,455,000 \\
4,760,000 \\
4,692,000 \\
4,074,000 \\
4,882,000 \\
5,402,000 \\
5,833,700 \\
7,200,890 \\
9,006,200\end{array}$ & $\begin{array}{l}1,198,000 \\
1,338,300 \\
1,46 n, 100 \\
1,434,900 \\
1,300,000 \\
1,552,600 \\
1,682,500 \\
1,730,000 \\
2,252,200 \\
2,547,900\end{array}$ & $\begin{array}{r}306,293 \\
398,159 \\
435,281 \\
444,268 \\
460,576 \\
535,202 \\
598,310 \\
716,194 \\
947,184 \\
1,182,226\end{array}$ \\
\hline
\end{tabular}

Ownership and production of companies operating iron mines, blast furnaces, and steel plants in Luxemburg, 1913.

\begin{tabular}{|c|c|c|c|c|c|c|c|}
\hline \multirow{2}{*}{ Company. } & \multirow{2}{*}{$\begin{array}{l}\text { Mineral } \\
\text { lands } \\
\text { (hec- } \\
\text { tares). }\end{array}$} & \multicolumn{3}{|c|}{ Blast furnaces. } & \multicolumn{3}{|c|}{ Stecl plants. } \\
\hline & & $\begin{array}{l}\text { Nutu- } \\
\text { ber in } \\
\text { blast. }\end{array}$ & $\begin{array}{l}\text { Total } \\
\text { num- } \\
\text { ber. }\end{array}$ & $\begin{array}{l}\text { Produc- } \\
\text { tion } \\
\text { (tons). }\end{array}$ & Num- & Equipment. & $\begin{array}{l}\text { Produc- } \\
\text { tion } \\
\text { (tons). }\end{array}$ \\
\hline GERMAN. & & & & & & & \\
\hline $\begin{array}{l}\text { Gelsenkirchener Bergwerks } \\
\text { A. G. }\end{array}$ & 580 & 11 & 11 & 927,900 & 1 & Four 21-ton Thomas. . & \\
\hline $\begin{array}{l}\text { Eisen und Stahlwerk von } \\
\text { Steinfort. }\end{array}$ & 150 & 3 & 3 & 70,000 & 0 & Two electric........... & \\
\hline $\begin{array}{l}\text { Deutsch-Luxemburgische } \\
\text { Bergwerks } 11 \text {. Hütten } \\
\text { A. G. }\end{array}$ & 1,950 & 8 & 10 & 450,000 & 1 & Five 24-ton 'Thomas... & $\cdots$ \\
\hline $\begin{array}{l}\text { Société des hauts fourncaux } \\
\text { do Rumelange-St. Ing. } \\
\text { bert. }\end{array}$ & 150 & 3 & 3 & 160,000 & 0 & $\ldots \ldots \ldots \ldots \ldots$ & 0 \\
\hline Total, German........ & 2,830 & 25 & 27 & $1,607,900$ & 2 & & $\ldots \ldots \ldots$ \\
\hline $\begin{array}{l}\text { BELGLAN. } \\
\text { Société anonyme d'Ougrée- } \\
\text { Marihaye. }\end{array}$ & 135 & 4 & 4 & 100,000 & 1 & Three 12-ton Thomas.. & $\ldots \ldots \ldots$ \\
\hline $\begin{array}{l}\text { FRENCH, BELGLAN, AND } \\
\text { LUXEMBURGIAN. }\end{array}$ & & & & & & & \\
\hline $\begin{array}{l}\text { Société des aciéries réunies } \\
\text { do Burbach, Eich, Dude- } \\
\text { lange. }\end{array}$ & 610 & 15 & 15 & 750,000 & 3 & $\begin{array}{l}\text { Eight 25-ton Thomas, } \\
\text { four 25-ton Martin, } \\
\text { two clectric. }\end{array}$ & .......... \\
\hline Grand total.... & 3,575 & 44 & 46 & $2,547,900$ & 6 & $\begin{array}{l}\text { Nine 24-ton Thomas, } \\
\text { eight 25-ton Thomas, } \\
\text { three 12-ton Thomas, } \\
\text { four 25-ton Martia, } \\
\text { four electria. }\end{array}$ & $1,182,228$ \\
\hline
\end{tabular}


The production of pig iron in 1911 and 1912 was divided into various grades, valued as follows:

Pig iron produced in Luxemburg, 1911-12.

\begin{tabular}{|c|c|c|c|c|}
\hline \multirow[b]{2}{*}{ Grade. } & \multicolumn{2}{|c|}{1911} & \multicolumn{2}{|c|}{1912} \\
\hline & $\begin{array}{l}\text { Quantity } \\
\text { (tons). }\end{array}$ & $\begin{array}{c}\text { Value } \\
\text { (francs). }\end{array}$ & $\begin{array}{l}\text { Quantity } \\
\text { (tons). }\end{array}$ & $\begin{array}{c}\text { Value } \\
\text { (francs). }\end{array}$ \\
\hline \multirow[t]{2}{*}{ 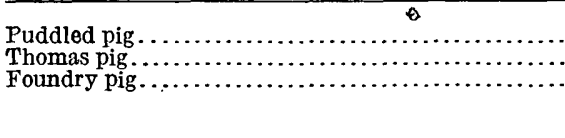 } & $\begin{array}{r}46,208 \\
1,477,350 \\
205,417\end{array}$ & $\begin{array}{r}2,546,747 \\
57,563,916 \\
12,054,904\end{array}$ & $\begin{array}{r}23,341 \\
2,052,379 \\
176,419\end{array}$ & $\begin{array}{r}1,289,786 \\
123,740,738 \\
10,758,235\end{array}$ \\
\hline & $1,728,975$ & $72,165,567$ & $2,252,139$ & $135,788,759$ \\
\hline
\end{tabular}

Average value, $1911,59.09$ francs per ton; $1912,60.29$ francs per ton.

The 2,550,000 tons of pig iron produced in Luxemburg in 1913 was distributed according to the following table:

Approximate distribution of pig iron smelted in Luxemburg, 1913.

Tons.

Luxemburg steel plants........................ 1, 460, 000

Luxemburg foundries.......................... 50,000

Westphalia and Rhine provinces.................. $\quad 650,000$

Sarre district and Bavarian Palatinate................ 290,000

Other parts of Germany $\ldots \ldots \ldots \ldots \ldots \ldots \ldots \ldots \ldots \ldots \ldots . \quad 100,000$

$2,550,000$

The manufacture of finished iron products by the Luxemburg foundries in 1911 and 1912 was as follows:

Iron products manufactured by foundries in Luxemburg, 1911-12.

\begin{tabular}{|c|c|c|c|c|}
\hline \multirow{2}{*}{ Product. } & \multicolumn{2}{|c|}{1911} & \multicolumn{2}{|c|}{1912} \\
\hline & $\begin{array}{l}\text { Quantity } \\
\text { (tons). }\end{array}$ & $\begin{array}{c}\text { Value } \\
\text { (francs). }\end{array}$ & $\begin{array}{l}\text { Quantity } \\
\text { (tons). }\end{array}$ & $\begin{array}{c}\text { Value } \\
\text { (francs). }\end{array}$ \\
\hline $\begin{array}{l}\text { Castings........ } \\
\text { Pipes........... } \\
\text { Machines...... } \\
\text { Miscellaneous.. }\end{array}$ & $\begin{array}{r}393 \\
365 \\
15,245 \\
16,002\end{array}$ & $\begin{array}{r}134,553 \\
83,585 \\
214,999 \\
2,360,070\end{array}$ & $\begin{array}{r}663 \\
32 \\
20,199 \\
20,893\end{array}$ & $\begin{array}{r}234,125 \\
80,059 \\
2,804,129 \\
3,046,304\end{array}$ \\
\hline
\end{tabular}

Average value, 1911, 147.48 francs per ton; 1912, 145.82 franes per ton.

\section{STEEL INDUSTRY.}

In 1913 there were 6 steel plants in Luxemburg owned by 4 companies; these plants were equipped with 20 Thomas converters having a total capacity of 457 tons, 4 Martin furnaces with a capacity of 100 tons, 4 electric furnaces, and 4 rolling mills. The average production was 3,400 tons of crude steel per day.

The table on page 65 gives the principal statistics concerning the equipment of these plants. 
The number of men employed in the steel plants was about 5,000; the wages were equal to approximately 14 francs per ton of steel.

Steel produced in Luxemburg, 1911-12.

\begin{tabular}{|c|c|c|c|c|}
\hline \multirow{2}{*}{ Product. } & \multicolumn{2}{|c|}{1911} & \multicolumn{2}{|c|}{1912} \\
\hline & $\begin{array}{l}\text { Quantity } \\
\text { (tons). }\end{array}$ & $\begin{array}{c}\text { Value } \\
\text { (francs). }\end{array}$ & $\begin{array}{l}\text { Quantity } \\
\text { (tons). }\end{array}$ & $\begin{array}{c}\text { Value } \\
\text { (francs). }\end{array}$ \\
\hline \multirow[t]{2}{*}{ 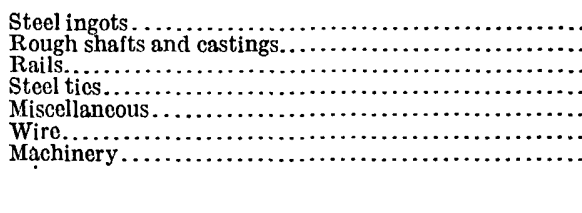 } & $\begin{array}{r}7,760 \\
278,637 \\
26,153 \\
8,863 \\
335,000 \\
44,238 \\
15,453\end{array}$ & $\begin{array}{r}1,477,109 \\
29,929,774 \\
3,791,710 \\
1,185,426 \\
43,492,455 \\
5,529,751 \\
3,833,011\end{array}$ & $\begin{array}{r}7,145 \\
376,330 \\
23,875 \\
20,166 \\
446,221 \\
54,039 \\
18,409\end{array}$ & $\begin{array}{r}107,222 \\
43,142,828 \\
3,521,514 \\
2,747,620 \\
64,997,963 \\
6,754,890 \\
3,262,004\end{array}$ \\
\hline & 716,104 & $89,239,236$ & 946,185 & $124,534,041$ \\
\hline
\end{tabular}

\section{CORPORATE OWNERSHIP.}

The iron and steel industry of Luxemburg is almost entirely controlled by six corporations, of which four are German, one Belgian, and one of mixed capital of which one-ninth is German. Some iron mines with small capitalization operated by individuals are independent of the big companies. These are owned chiefly by Luxemburgers, and their production is not large and can not be greatly increased, for the large companies control most of the ore reserves. The following is a summary of the available information about the large companies in 1913:

\section{GERMAN-CONTROLLED COMPANIES.}

Gelsenkirchener Bergwerks Aktien-Gesellschaft. Capital, 225,500,000 francs. This company owns two large blast-furnace plants-one at Esch-sur-Alzette and a new plant at Beval-lez-Esch-and one steel plant in Luxemburg. The equipment comprises 11 blast furnaces having a daily output of 3,000 tons of pig; in the steel plant, Thomas furnaces, four 24-ton converters; rolling mill; slag mill. In addition to its property in Luxemburg the company owns furnaces and iron lands in Lorraine Annexée.

Eisen und Stahlwerk von Steinfort. Capital, 7,000,000 francs, chiefly German with some Luxemburgian. This corporation appears to have been formed by a combination of the interests of Jules Collart et Cie. and the Société Felton et Guilleaume of Cologne. It owns, at Steinfort, three blast furnaces having a daily output of 210 tons of pig, and two electric furnaces manufacturing special steels.

Deutsch-Luxemburgische Bergwerks und Hütten-Aktiengesellschaft. Capital, $162,800,000$ francs, entirely German. Its plant at Differdange consists of 10 blast furnaces having a daily output of 1,350 tons of pig, a steel plant with five Thomas converters of 20 to 24 tons, a Grey rolling mill, and a slag mill. The company has large smelting and mining interests in Westphalia, the Sarre district, and Lorraine Annexée. It has leased for 30 years the furnaces and plants of the Société des hauts fourneaux de Rumelange-St. Ingbert. 
Société des hauts fourneaux de Rumelange-St. Ingbert. Capital, 7,500,000 francs. The ownership of this company is mixed, but the Deutsch-Luxemburgische Bergwerks und Hütten-Aktien-Gesellschaft owns the controlling interest in the capital stock. Its plant at Rumelange consists of three blast furnaces having a daily output of 450 to 500 tons of pig. The company owns iron lands and furnaces in Lorraine Annexée, as well as in Luxemburg.

\section{BELGIAN-CONTROLLED COMPANIES.}

Société anonyme d'Ougrée-Marihaye. Capital, 40,000,000 francs. Its plant at' Rodange consists of four blast furnaces having a daily output of 580 tons of pig, a steel mill equipped with three 12-ton Thomas converters, a rolling mill, and a foundry. Its Rodange plant is eaid to have been valued at 4,000,000 francs. The company has smelting and mining interests in Lorraine Annexee, the Sarre district, and French Lorraine. It has a contract with the German company Gewerkschaft Quaint, of Trèves, for the sale of its product.

\section{MIXED CAPITAL (FREN CH, BELGIAN, LUXEMBURGIAN, AND GERMAN).}

Société des aciéries réunies de Burbach, Eich, Dudelange. Capital, 16,000,000 francs. The capital stock is six-nin ths Belgian, one-ninth French, one-ninth Luxemburgian, and one-ninth German. The corporation was formed in 1911 by the union of the Société des forges de Saarbruck and the Société la Gallais-Metz. The company is affiliated with the Eschweiler Bergwerks Gesellschaft, which has large holdings of coal land in Westphalia. It is thought that the controlling interest of the company is German. Its Luxemburg holdings are situated as follows: Dommeldange, three blast furnaces with a daily output of 350 tons of pig, two Martin furnaces, two electric furnaces for the manufacture of special steels, a rolling mill, and a steel foundry. Eich-les-Luxemburg, a foundry, shops for the manufacture of structural steel, and a slag-cement mill. Dudelange, six blast furnaces having a daily output of 900 tons of pig, four Thomas 25-ton converters, two Martin furnaces of 25 tons each, a foundry, a slag mill, and a plant for the manufacture of briquets. This plant was valued at $11,000,000$ francs. Esch-sur-Alzette, six blast furnaces having a daily output of 1,100 tons of pig, four Thomas furnaces of 25 tons each, a rolling mill, a cement plant, and a slag mill. This plant was valued at $26,000,000$ francs. In addition to its furnaces, mines, and steel plarts in Luxemburg, the company has large interests in the Sarre district.

Luxemburg iron-ore reserves owned by different companies, 1919, in tons.

\begin{tabular}{|c|c|c|}
\hline Company. & $\begin{array}{l}\text { German- } \\
\text { owned. . }\end{array}$ & Total. \\
\hline \multirow{2}{*}{ 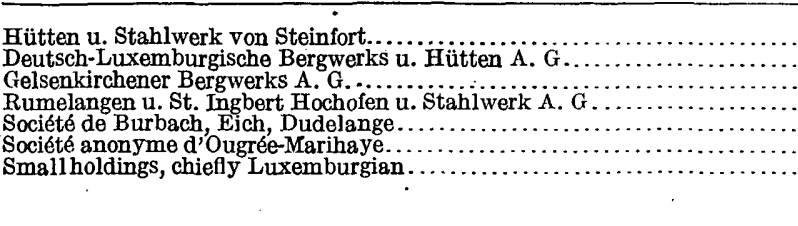 } & $\begin{array}{r}33,537,000 \\
74,504,000 \\
21,770,000 \\
\mathbf{9}, 925,000 \\
\mathbf{6}, 396,000 \\
\ldots . . . . . . . . . . . \\
\end{array}$ & $\begin{array}{r}33,537,000 \\
74,504,000 \\
21,770,000 \\
9,925,000 \\
58,435,000 \\
27,035,000 \\
14,794,000\end{array}$ \\
\hline & $146,132,000$ & $240,000,000$ \\
\hline
\end{tabular}


Capitalization of companies operating iron-ore mines, blast furnaces, and steel plants in Luxemburg, 1913.

\begin{tabular}{|c|c|c|}
\hline Company. & $\begin{array}{l}\text { Capitaliza- } \\
\text { tion (francs). }\end{array}$ & Remarks. \\
\hline GERMAN. & & \multirow{4}{*}{$\begin{array}{l}\text { A corporation formed by a consolidation o } \\
\text { Jules Collart et Cie. and Société Felton et } \\
\text { Guilleaume, of Köln. } \\
\text { Operates under a } 30-y \text {-year lease the plants o } \\
\text { Société des hauts fourneaux de Rume } \\
\text { lange-St. Ingbert. } \\
\text { Controlled by the Deutsch-Luxemburgisch } \\
\text { Bergwerks u. Hütten A. G., which own } \\
\text { 30,000,000 marks of capital stock. }\end{array}$} \\
\hline $\begin{array}{l}\text { Gelsenkirchener Bergwerks A. G............... } \\
\text { Eisen u. Stahlwerk von Steinfort. } \ldots \ldots \ldots \ldots \ldots\end{array}$ & $\begin{array}{r}225,500,000 \\
7,000,000\end{array}$ & \\
\hline $\begin{array}{l}\text { Deutsch-Luxemburgische Bergwerks a. Hüt- } \\
\text { ten A. G. }\end{array}$ & $162,800,000$ & \\
\hline $\begin{array}{l}\text { Société des hauts fourneaux de Rumelange- } \\
\text { St. Ingbert. }\end{array}$ & $7,500,000$ & \\
\hline Total, German......... & $402,800,000$ & - \\
\hline BELGIAN. & \multirow{3}{*}{$40,000,000$} & \\
\hline Société anonyme d'Ougrée-Marihaye... & & \\
\hline $\begin{array}{l}\text { FRENCH, BELGIAN, LUXEMBURGIAN, AND } \\
\text { GERMAN. }\end{array}$ & & \\
\hline $\begin{array}{l}\text { Société des aciéries réunies de Burbach, Eich, } \\
\text { Dudelange. }\end{array}$ & $16,000,000$ & \multirow[t]{2}{*}{$\begin{array}{l}\text { Capital stock is six-ninths Belgian, one- } \\
\text { ninth French, one-ninth Luxemburgian, } \\
\text { one-ninth German. }\end{array}$} \\
\hline Grand total...$\ldots \ldots \ldots \ldots \ldots \ldots$ & $458,800,000$ & \\
\hline
\end{tabular}

It appears that the German interests in the iron and steel industry of Luxemburg are as follows: Iron-ore reserves, 61 per cent; pig-iron industry, 65 per cent; steel industry, 46 per cent.

Although rather definite information is available about German ownership in the iron-ore and pig-iron industries, the facts collected about the steel plants are more or less conflicting. The capacities of the several steel plants indicate that 46 per cent of the steel is made by German capital. On the other hand, the report of the Deutsch-Luxemburgische company for 1912 suggests that it may be producing over half the steel output. The lower figure is used in the following tables, which give the data on German ownership and profits. The table showing value of plants and of iron-ore reserves in German ownership is based on different data from those used in estimating profits. The profits show a return of about 7 per cent on the estimated value of iron reserves and iron and steel plants.

Estimated profits on German iron and steel plants in Luxemburg, 1919.

16 per cent of iron ore mined but not smelted in Luxemburg (total 2,900,000 tons), profit 0.75 franc a ton.......

65 per cent of pig iron produced but not refined in Luxemburg (total 1,090,000 tons), profit 8 francs a ton........ 45 per cent of steel produced (total 1,182,266 tons), profit

(including that on iron ore and pig) 20 francs a ton..... 11, 270, 000
Francs.

$1,230,000$

$5,700,000$ 
Estimated value of German interests in Luxemburg iron and steel industry.

$142,000,000$ tons of iron ore at 0.75 franc a ton, to be mined Francs.

in 30 years; present value..................... 35, 000, 000

Value of furnace and steel plants $(60$ francs per ton of annual output of pig iron and 300 francs per ton of annual output of steel, including blast furnaces) $\ldots \ldots \ldots \ldots \ldots \ldots \ldots 230,000,000$

SARRE DISTRICT. ${ }^{13}$

\section{By Alfred H. Brooks.}

INTRODUCTION.

\section{The iron and steel industry of the Sarre district (see Pl. I) has} been developed as a result of the close proximity of the Lorraine

13 This report was originally written on the basis of German ownership of the Sarre district, and to revise it now to make it accord with the terms of the peace treaty would beimpracticable. The following extracts from the peace treaty (Cong. Record, vol. 58, pp. 2481-2484, July 10, 1919) have more or less bearing on the subject matter of this report.

"ARTICLE 45. As compensation for the destruction of the coal mines in the north of France and as part payment toward the total reparation due from Germany for the damages resulting from the war, Germany cedes to France in full and absolute possession, with exclusive rights of exploitation, unencumbered and freefrom all debts and charges of any kind, the coal mines situated in the Saar Basin as defined in article 48.

"ARTtCLE 48. The boundaries of the territory of the Sarar Basin, as dealt with in the present stipulations, will be fixed as follows:

"On the south and southwest, by the frontier of France as fixed by the present treaty.

"On the northwest and north by a line following the northern administrative boundary of the Kreis of Merzig from the point where it leaves the French frontier to the point where it meets the administrative boundary separating the commune of Saarhölzbach from the commune of Britten; following this communal boundary southward and reaching the administrative boundary of the canton of Merzig so as to include in the territory of the Saar Basin the canton of Mettlach, with the exception of the commune of Britten; following successively the northern administrative boundaries of the cantons of Merzig and Haustadt, which are incorporated in the aforesaid Saar Basin, then successively the administrative boundaries separating the Kreise of Sarrelouis, Ottweiler, and St.-Wendel from the Kreise of Merzig, Trèves (Trier), and the Principality of Berkenfeld as far as a point situated about 500 meters north of the village of Furschweiler (viz, the highest point of the Metzelberg).

"On the northeast and east, from the last point defined above to a point about $3 \frac{1}{2}$ kilometers east-northeast of St.-Wendel; a line to be fixed on the ground passing east of Furschweiler, west of Roschberg, east of points 418, 329 (south of Roschberg), west of Leitersweiler, northeast of point 464, and following the line of the crest southward to its junction with the administrative boundary of the Kreis of Kusel; thence in a southerly direction the boundary of the Kreis of Kusel, then the boundary of the Kreis of Homburg toward the south-southeast to a point situated about 1,000 meters west of Dunzweiler; thence to a point about 1 kilometer south of Hornbach; a line to be fixed on the ground passing through point 424 (about 1,000 meters southeast of Dunzweiler), point 363 (Fuchs-Berg), point 322 (southwest of Waldmohr), then east of Jägersburg and Erbach, then encircling Homburg, passing through the points 361 (about $2 \frac{1}{2}$ kilometers northeast by east of that town), 342 (about 2 kilometers southeast of that town), 347 (Schreiners-Berg), 356, 350 (about $1 \frac{1}{2}$ kilometers southeast of Schwarzenbach), then passing east of Einöd, southeast of points 322 and 333, about 2 kilometers east of Webenheim, about 2 kilometers east of Mimbach, passing east of the plateau which is traversed by the road from Mimbach to Böckweiler (so as to include this road in the territory of the Saar Basin), passing immediately north of the junction of the roads from Böckweiler and Altheim situated about 2 kilometers north of Altheim, then passing south of Ringweilerhof and north of point 322 , rejoining the frontier of France at the angle which it makes about 1 kilometer south of Hornbach. * * *

"A commission composed of five members, one appointed by France, one by Germany, and three by the council of the League of Nations, which will select nationals of other powers, will be constituted within fifteen days from the coming into force of the present treaty, to trace on the spot the frontier line described . above.

"In thoseparts of the preceding line which do not coincide with administrative boundaries the commission will endeavor to keep to the line indicated, while taking into consideration, so far as is possible, local, eco. nomic interests and existing communal boundaries.

"The decisions of this commission will be taken by a majority, and will be binding on the parties concerned.

"ARTICLE 49. Germanry renounces in favor of the League of Nations, in the capacity of trustee, the government of the territory defined above. 
"At the end of fifteen years from the coming into force of the present treaty the inhabitants of the said territory shall be called upon to indicate the sovereignty under which they desire to be placed.

"ARTicLe 50. The stipulations under which the cession of the mines in the Saar Basin shall be carried out together with the measures intended to guarantee the rights and the well-being of the inhabitants and the government of the territory, as well as the conditions in accordance with which the plebiscite hereinbefore provided for is to be made, are laid down in the annex hereto. This annex shall be considered as an integral * part of the present treaty, and Germany declares her adherence to it.

"ANNEX.

"In accordance with the provisions of articles 45 to 50 of the presenttreaty, thestipulations under which the cession by Germany to France of the mines of the Saar Basin will be effected, as well as the measures intended to insure respect for the rights and well-being of the population and the government of the territory, and the conditions in which the inhabitants will be called upon to indicate the sovereignty under which they may wish to be placed, have been laid down as follows.

" Chapter I. C'ession and exploitation of mining property.

"1. From the date of the coming into force of the present treaty, all the deposits of coal situated within the Saar Basin as defined in article 48 of the said treaty become the complete and absolite property of the French State.

"The French State will have the right of working or not working the said mines, or of transferring to a third party the right of working them, without having to obtain any previous authorization or to fulfll any formalities.

"The French State may always require that the German mining laws and regulations referred to below shall be applied in order to insure the determination of its rights.

"2. The right of ownership of the French State will apply not only to the deposits which are free and for which concessions have not yet been granted, but also to the deposits for which concessions have already been granted, whoever may be the present proprietors, irrespective of whether they belong to the Prussian State, to the Bavarian State, to other States or bodies, to companies, or to individuals, whether they have been worked or not, or whether a right of exploitation distinct from the right of the owners of the surface of the soil has or has not been recognized.

"As far as concerns the mines which are being worked, the transfer of the ownership to the French State will apply to all the accessories and subsidiaries of the said mines, in particular to their plant and equipment both on and below the surface, to their extracting machinery, their plants for transforming coal into electric power, coke, and by-products, their workshops, means of communication, electric lines, plant for catching and distributing water, land, buildings, such as oflices, managers', employees', and workmen's dwellings, schools, hospitals, and dispensaries, their stocks and supplies of every description, their archives and plans, and in general everything which those who own or exploit the mines possess or enjoy for the purpose of exploiting the mines and their accessories and subsidiaries.

"The transfer will apply also to the debts owing for products delivered before the entry into possession by the French State, and after the signature of the present treaty, and to deposits of money made by customers, whose rights will be guaranteed by the French State.

"4. The French State will accuire the property free and clear of all debts and charges. Nevertheless, the rights acquired, or in course of being acquired, by the employees of the mines and their accessories and subsidiaries at the date of the coming into force of the present treaty, in connection with pensions for old age or disability, will not be affected. In return, Germany must pay over to the French State a sum representing the actuarial amounts to which the said employees are entitled.

" 5 . The value of the property thus ceded to the French State will be determined by the reparation commission referred to in article 233 of Part VIII (Reparation) of the present treaty.

"This value shall be credited to Germany in part payment of the amount due for reparation.

"It will be for Germany to indemnify the proprietors or parties concerned, whoever they may be.

"6. No tariff shall be established on the German railways and canals which may directly or indirectly discriminate to the prejudice of the transport of the personnel or products of the mines and their accessories or subsidiaries, or of the material necessary to their exploitation. Such transport shall enjoy all the rights and privileges which any international railway conventions may guarantee to similar products of French origin.

"7. The equipment and personnel necessary to insure the dispatch and transport of the products of the mines and their accessories and subsidiaries, as well as the carriage of workmen and employees, will be provided by the local railway administration of the basin.

\footnotetext{
$*$ * * *
}

"9. The French State shall always be entitled to demand the application of the German mining laws and regulations in force on November 11, 1918, excepting provisions adopted exclusively in view of the state of war, with a view to the acquisition of such land as it may judge necessary for the exploitation of the mines and their accessories and subsidiaries.

"The payment for damage caused to immovable property by the working of the said mines and their accessories and subsidiaries shall be mado in accordance with the German mining laws and regulations above referred to.

"10. Every person whom the French State may substitute for itself as regards the whole or part of its rights to the exploitation of the mines and their accessories and subsidiaries shall enjoy the benefit of the privileges provided in this annex. 
iron ore and the Sarre coal. There is an abundance of coal in the Sarre district but practically no iron ore. ${ }^{14}$ The coal, though extensively used, is not of the best coking variety. Most of the ore is - brought from Lorraine Annexée, the railroad haul being about 50 kilometers.

"11. The mines and other immovable property which become the property of the French Statemay never be made the subject of mcasures of forfeiture, forced sale, expropriation, or requisition, nor of any other measure affecting the right of property.

"The personnel and the plant connected with theexploitation of these mines or their accessories and subsidiaries, as well as the product extracted from the mines or manufactured in their accessories and subsidiaries, may not at any time be made the subject of any measures of requisition.

"The exploitation of the mines and their accessories and subsidiaries, which become the property of the French State, will continue, subject to the provisions of paragraph 23 below, to be subject to the régime established by the German laws and regulations in force on November 11, 1918, excepting provisions adopted exclusively in view of the state of war.

"The rights of the workmen shall similarly be maintained, subject to the provisions of the said paragraph 23, as established on November 11, 1918, by the German laws and regulations above referred to.

"No impediment shall be placed in the way of theintroduction or employment in the mines and their accessories and subsidiaries of workmen from without the basin.

"13. The amount contributed by the mines and their accessories and subsidiaries, either to the local budget of the territory of the Saar Basin or to the communal funds, shall be fixed with due regard to the ratio of the value of the mines to the total taxable wealth of the basin.

\footnotetext{
* * * * * * * * * * * *
}

“15. The French State shall enjoy complete liberty with respect to the distribution, dispatch, and sale prices of the products of the mines and their accessories and subsidiaries.

"Nevertheless, whatever may be the total product of the mines, the French Government undertakes that the requirements of local consumption for industrial and domestic purposes shall always be satisfied in the proportion existing in 1913 between the amount consumed locally and the total output of the Saar Basin.

$$
\text { "Chapter II. Government of the territory of the Saar Basin. }
$$

"16. The government of the territory of the Saar Basin shall be intrusted to a commission representing the League of Nations. This commission shall sit in the territory of the Saar Basin.

"17. The governing commission provided for by paragraph 16 shall consist of five members chosen by the council of the League of Nations and will include one citizen of France, one native inhabitant of the Saar Basin, not a citizen of France, and three members belonging to three countries other than France or Germany.

$$
\text { * * }
$$

"The members of the governing commission will be entitled to a salary which will be fixed by the council of the League of Nations and charged on the local revenues.

“31. The territory of the Saar Basin as defined by article 48 of the present treaty shall be subjected to the French customs régime. The receipts from the customs duties on goods intended for local consumption shall be included in the budget of the said territory after deduction of all costs of collection.

"No export tax shall be imposed upon metallurgical products or coal exported from the said territory to Germany, nor upon German exports for the use of the industries of the territory of the Saar Basin.

"Natural or manufactured products originating in the basin in transit over German territory and, similarly, German products in transit over the territory of the basin shall be free of all customs duties.

"Products which both originate in and pass from the basin into Germany shall be free of import duties for a period of five years from the date of the coming into force of the present treaty, and during the same period articles imported from Germany into the territory of the basin for local consumption shall likewise be free of import duties.

"During these five years the French Government reserves to itself the right of limiting to the annual average of the quantities imported into Alsace-Lorraine and France in the years 1911 to 1913 the quantities which may be sent into France of all articles coming from the basin which include raw materials and semimanufactured goods imported duty free from Germany. Such average shall be determined after reference to all available official information and statistics.

“33. The governing commission shall have power to decide all questions arising from the interpretation of the preceding provisions."

$14 \mathrm{~A}$ little iron ore is associated with the coal, and this was formerly mined but now has no value. See Roesler, Max, The iron-ore resources of Europe: U. S. Geol. Survey Bull. 706 (in press). 
The furnaces and steel works are owned by seven different corporations, and some of these also own coal lands and coking plants, as well as having mining and metallurgic interests in the other districts. Their total capitalization is about $270,000,000$ francs. A rough estimate indicates that the total value of the plants in this district is about 500,000,000 francs. The gross value of the output of iron and steel in 1913 is estimated to have been 270,000,000 francs, and the total profit 47,000,000 francs. The value of the coal mines in the district is estimated to be $411,000,000$ francs, and that of the coal products in 1913 about $300,000,000$ francs, yielding a profit of about $20,000,000$ francs.

\section{SARRE COAL FIELD.}

The boundaries of the Sarre coal field are fairly well known on the north, south, and east. On the west the coal beds plunge under a heavy cover of younger strata and the limits will be determined by the depth of profitable mining. The coal formation has been traced westward to the old boundary between French Lorraine and Lorraine Annexée, but is here undeveloped. It is also known to occur in French Lorraine north and northeast of Nancy, where coal beds have been found by boring at depths of 800 to 1,500 meters. Most of the developed field lies in the Sarre district of Rheinland, but there is some of it in the Bavarian Palatinate, and in Lorraine Annexée there is a very large area in which more or less coal has been found by boring. It is impossible, therefore, to give exact figures on either the area or the tonnage of the field. The following table summarizes the available information on the area of the entire field. Of the output in 1913, 78 per cent was taken from the mines in the Sarre district proper (Rheinland).

Area of Sarre coal field, in square kilometers.

\begin{tabular}{|c|c|c|}
\hline Province. & $\begin{array}{c}\text { Area of } \\
\text { known } \\
\text { coal lands. }\end{array}$ & $\begin{array}{c}\text { Area of } \\
\text { possible } \\
\text { coal lands. }\end{array}$ \\
\hline \multirow{2}{*}{ 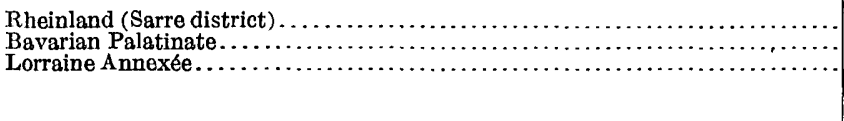 } & $\begin{array}{r}100,000 \\
5,000 \\
30,000\end{array}$ & $\begin{array}{l}40,000 \\
60,000\end{array}$ \\
\hline & 135,000 & 100,000 \\
\hline
\end{tabular}

The best information available indicates that the Sarre coal field contains from 27 to 32 workable coal beds, aggregating 38 to 43 meters in thickness. Many of the coal beds are separated into a number of benches by seams of bone and shale.

The total coal reserves of the Sarre Basin to a depth of 2,000 meters have been estimated at $16,548,000,000$ tons. Of this total $9,769,000,000$ tons occurs in beds lying within 1,200 meters of the 
surface. The total coking coal to a depth of 2,000 meters is estimated at $8,299,000,000$ tons, of which $4,086,000,000$ tons lies within 1,200 meters of the surface. Only about $4,500,000,000$ to $5,000,000,000$ tons of the total coal reserve lies in the developed part of the field. The rest of the coal (about 75 per cent) is in such areas or at such a depth that it is known only by drilling.

The coking coal of the Sarre field is of an inferior grade to that of the French, Belgian, and Westphalian fields, with which it comes into competition. Its most direct competitor is the Westphalian coal, which yields about 78 per cent of coke, as compared to about 50 per cent for the Sarre coal. Even in the Sarre district itself, as is shown below, much Westphalian coal, as well as some coke, is used. Moreover, the Sarre coke is not strong enough for blast-furnace use. The best coking practice in the Sarre field provides for an admixture of 20 per cent of Westphalian coal in the coke ovens. For furnace charges 150 tons of Westphalian coke is considered the equal of 180 tons of Sarre coke. Reducing these factors indicates that the value of the Sarre coking coal for furnace use is 62 per cent of the value of the Westphalian coal. In blast-furnace practice it is customary when conditions permit to make the charge of equal quantities of Sarre and Westphalian coke.

\section{COAL-LAND CONCESSIONS.}

Before the war most of the land known to be underlain by workable coal beds, including practically all that part of the field lying in the Sarre district (Rheinland), was owned and exploited by the Royal Prussian Government. The Bavarian Government also owned coal land and operated two mines in the Palatinate part of the field. In addition to the Government-owned land a few concessions had been made in both the Sarre and the Palatinate to private corporations. Very large concessions, consisting chiefly of undeveloped and in part of unproved coal land, have been granted in the part of the field lying in Lorraine Annexée.

The following table gives the approximate areas of the coal lands in Government ownership and in private ownership. There is evidence that there may be coal under at least 100,000 hectares additional. In 1913 the mineral rights to these lands belonged to the Prussian Government, but application had been made for concessions of about 5,000 hectares lying adjacent to the old boundary between French Lorraine and Lorraine Annexée.

Coal land in Government and private ownership in Sarre field, 1913, in hectares.

\begin{tabular}{|c|c|c|c|c|}
\hline - & $\begin{array}{l}\text { Rhein- } \\
\text { land. }\end{array}$ & $\begin{array}{c}\text { Bavarian } \\
\text { Pala- } \\
\text { tinate. }\end{array}$ & $\begin{array}{l}\text { Lorraine } \\
\text { Annexée. }\end{array}$ & Total. \\
\hline \multirow[t]{2}{*}{$\begin{array}{l}\text { Government... } \\
\text { Private............ }\end{array}$} & $\begin{array}{r}110,000 \\
112\end{array}$ & $\begin{array}{r}4,370 \\
630\end{array}$ & $42,570^{\circ}$ & $\begin{array}{r}114,370 \\
43,312 \\
\end{array}$ \\
\hline & 110,112 & $\overline{5,000}$ & 42,570 & 157,682 \\
\hline
\end{tabular}


A list of the corporations owning coal land in the Sarre field (see Pl. I), so far as these are known, is given below.

\section{LORRAINE ANNEXÉE.}

Société internationale des houillers (International Kohlenbergwerk Aktien-Gesellschaft). Capital, 24,000,000 francs; ownership about equally divided between Germans and French. This company owns 33 concessions (6,600 hectares), the cost of which was 7,920,000 francs. Thus far there has been no production.

Société de charbonnage de la Houve. Amount of capital not known. It appears to be of mixed ownership but is probably controlled by German capital. This company owns one of the original concessions in the field, made in 1850, comprising about 1,500 hectares of land. Annual coal production about 350,000 tons.

Les petits fils de François de Wendel et Cie. This French company has a capital of 30,000;000 francs and has large interests in mines, furnaces, and steel plants in both France and Germany. It owns about 4,400 hectares of coal land in the Sarre district and has opened six coal mines, in which the annual production before the war was $2,386,000$ tons.

Société de charbonnages de Sarre et Moselle à Krilingen (Saar und Mosel Bergwerks Gesellschaft $\mathrm{zu}$ Krilingen). The capital of this company is $22,120,000$ francs. It was formerly controlled by the French but in 1900 passed into German ownership. The company owns 15,670 hectares of coal land, which has been developed by three shafts, 500 to 790 meters deep, and 70 coke ovens with by-product plants. In 1913 it produced $1,236,580$ tons of coal and 95,484 tons of coke.

Association allemande autrichienne (Deutsche-oesterreichisch Bergwerk Gesellschaft). This is one of the largest coal companies in Germany and has a capital of $21,600,000$ francs. It owns about 7,250 hectares of undeveloped coal lands in the Sarre Basin.

Société des forges Dillingen (Dillinger Hüttenwerke). This is a large German metallurgic company with a capital of $20,250,000$ francs. It owns about 5,000 hectares of undeveloped coal lands in the Sarre district.

Roechlingische Eisen und Stahlwerke. This is a large German mining and metallurgic company with a capital of $25,000,000$ francs. It owns about 3,850 hectares of undeveloped coal lands in the Sarre Basin.

Hostenbach Gewerkschaft. This German company, about which no details are known, owns about 3,400 hectares of undeveloped coal lands in the Sarre Basin.

RHEINLAND.

Roechlingische Eisen und Stahlwerke. This is a large German iron-mining and metallurgic company whose capital is $25,000,000$ francs. It owns about 112 hectares of coal lands in the Rheinland part of the Sarre field. The coal production from this area in 1913 was 200,000 tons. This concession was made in 1804.

BaVARIAN PALATINATE.

Frankenholz mine. The capitalization of this mining company is unknown, but the majority interests are owned by the French. The company owns about 630 hectares of coal land and operates one mine, which in 1913 produced about 400,000 tons of coal.

\section{COAL MINING.}

The coal beds of the Sarre field are commonly tilted at rather low angles but are broken by faults. The attitude of the beds favors cheaper mining than can be done in the coal fields of Westphalia, northern France, or Belgium. As the coal beds are for the most part under a thick cover of barren strata (75 to 1,000 meters), the mining 
is done by shafts. So far as known the deepest shafts are 800 meters deep, but the average depth of mining is probably less than half of this.

In 1913 fourteen Government mines producing 13,000,000 tons of coal and seven private mines producing $4,000,000$ tons were operated in the Sarre field. About 70,000 men were employed in the coal mines. It has long been recognized in Germany that the Government mines were less efficiently operated than those in private hands. Evidence of this difference is found in the reported cost of production. The average cost per ton of coal mined in the years 1906 to 1910 was 11.54 francs for the private mines and 13.50 francs for the Government mines. This ratio of cost appears to have continued for 1913, when the average profit, as reported, was 2.50 francs per ton for private mines and 2.15 francs per ton for Government mines, in spite of the fact that the private operators sold their coal cheaper than the Government. It should be noted, however, that these profits are much higher than those obtained in the French and Belgian coal mines. They probably do not take account of amortization, which would reduce them by 1 to 1.5 francs per ton. Further evidence of the better practice in the private mines is afforded by the annual coal. recovery per miner, which in 1913 was 261 tons for private mines and 229 tons for Government mines. The size of the mining operations in the Sarre field is indicated by the annual coal output per mine, which is about 800,000 tons.

As has been shown, the Sarre coal is inferior for coking to that from the competitive fields. It has, however, been extensively used in the local metallurgic industries. The annual coal and coke production, together with its relation to the metallurgic industries, is shown in the following table:

Coal and coke produced and consumed in the metallurgic industries of the Sarre district, 1904-1913, in tons.

\begin{tabular}{|c|c|c|c|c|c|c|c|}
\hline & \multirow[b]{2}{*}{ Year. } & \multirow[b]{2}{*}{$\begin{array}{l}\text { Coal pro- } \\
\text { duced. }\end{array}$} & \multirow[b]{2}{*}{$\begin{array}{l}\text { Coke pro- } \\
\text { duced. }\end{array}$} & \multirow{2}{*}{$\begin{array}{c}\text { Coking } \\
\text { coal } \\
\text { imported } \\
\text { from } \\
\text { West- } \\
\text { phalia. }\end{array}$} & \multicolumn{3}{|c|}{$\begin{array}{l}\text { Coke used in metallurgic plants } \\
\text { in the district. }\end{array}$} \\
\hline & & & & & $\begin{array}{c}\text { Sarre } \\
\text { coke.a }\end{array}$ & $\begin{array}{c}\text { Other } \\
\text { coke, } \\
\text { largely } \\
\text { West- } \\
\text { phalian. }\end{array}$ & Total. \\
\hline $\begin{array}{l}1904 . \\
1905 . \\
1906 . \\
1907 . \\
1908 . \\
1909 . \\
1910 . \\
1911 . \\
1912 . \\
1913 .\end{array}$ & 年, & 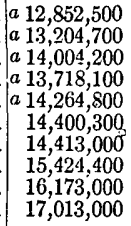 & $\begin{array}{r}a_{2}, 280,000 \\
a 2,340,100 \\
a_{2}, 487,000 \\
2,444,000 \\
2,552,100 \\
2,638,400 \\
2,739,200 \\
2,959,000 \\
2,997,600 \\
3,172,600\end{array}$ & $\begin{array}{l}588,200 \\
604,000 \\
641,900 \\
630,800 \\
658,400 \\
680,600 \\
706,500 \\
763,400 \\
773,500 \\
810,900\end{array}$ & $\begin{array}{l}1,140,000 \\
1,170,000 \\
1,243,500 \\
1,222,000 \\
1,276,100 \\
1,319,200 \\
1,369,600 \\
1,479,500 \\
1,497,500 \\
1,586,300\end{array}$ & $\begin{array}{rr}a & 85,800 \\
a & 158,700 \\
a & 199,500 \\
300,808 \\
371,800 \\
a & 256,600 \\
a & 414,000 \\
a & 351,000 \\
438,500 \\
432,500\end{array}$ & $\begin{array}{l}1,225,800 \\
1,328,700 \\
1,443,000 \\
1,522,800 \\
1,647,900 \\
1,575,800 \\
1,783,600 \\
1,830,500 \\
1,936,000 \\
2,018,800\end{array}$ \\
\hline
\end{tabular}

$a$ Estimated. 
In 1913 there were about 17 coking plants in the district, a large number of which were by-product plants: These coking plants included 2,240 ovens. Ten of these plants belong to the Prussian Government, one to a French company, and the others to German companies. The following table shows the ownership of the coke ovens so far as determined. The number of plants and ovens is in part estimated.

Ownership of coking plants in the Sarre coal field, 1913.

\begin{tabular}{|c|c|c|}
\hline Company. & Plants. & Ovens. \\
\hline \multirow[t]{2}{*}{ 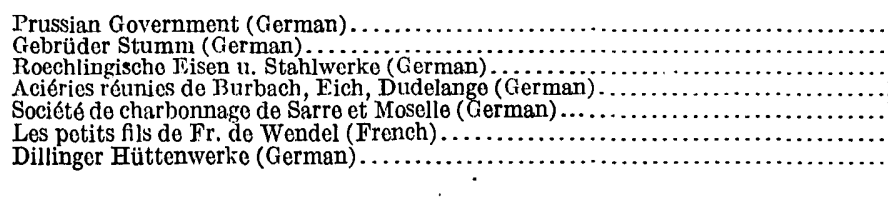 } & $\begin{array}{c}10 ? \\
1 \\
2 \\
1 \\
1 \\
1 \\
1\end{array}$ & $\begin{array}{c}570 ? \\
400 \\
280 \\
400 \\
70 \\
400 ? \\
120\end{array}$ \\
\hline & $\overline{17}$ & $\overline{2,240}$ \\
\hline
\end{tabular}

Had the Sarre coal not been in close competition with the better fuel from Westphalia, the field would undoubtedly have been more extensively developed. In this competitive trade the Sarre coal finds its best use for steam, gas, and domestic purposes. The following table shows the distribution of the Sarre coal in 1913:

Sarre coal consumed in the district and exported in 1919, in tons.

Consumed in. the district, including that used in coking

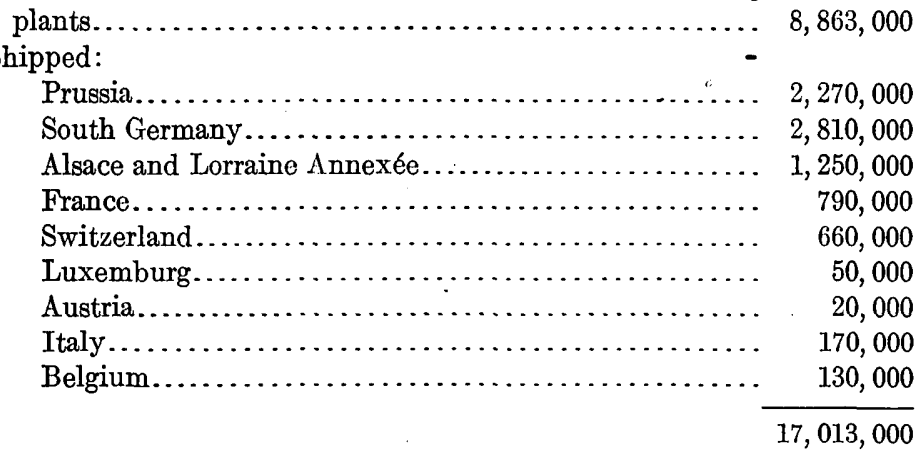

\section{MANUFACTURE OF PIG IRON AND STEEL.}

In 191329 blast furnaces having a total daily capacity of about 4,370 tons were operated in the Sarre district. In the same year 9 steel plants were operated, and these consumed not only practically all the pig iron produced in the district but also some 500,000 tons imported from French Lorraine. The steel plants were equipped with 21 Bessemer converters of an average capacity of 21 tons and 31 Martin furnaces with an average capacity of 21 tons. There were also 6 electric furnaces, at least 7 rolling mills, 4 foundries, 10 
puddling furnaces, 1 tube mill, and 1 armor-plate plant in the district.

These furnaces and plants produced 1,375,000 tons of pig and $2,080,000$ tons of raw steel. No accurate statistics regarding the output of finished and semifinished products are available, but these products in 1913 probably aggregated about 1,000,000 tons. The following table shows the growth of the pig-iron and steel production during the decade preceding 1913:

Pig iron and steel produced in the Sarre district, 1904-1913, in tons.

\begin{tabular}{|c|c|c|c|c|c|}
\hline \multirow[b]{2}{*}{ Year } & \multicolumn{3}{|c|}{ Pig iron. } & \multicolumn{2}{|c|}{ Steel. } \\
\hline & $\begin{array}{l}\text { Produced } \\
\text { in Sarre } \\
\text { district. }\end{array}$ & $\begin{array}{l}\text { Exported } \\
\text { to other } \\
\text { German } \\
\text { districts. }\end{array}$ & $\begin{array}{l}\text { Imported } \\
\text { from } \\
\text { Lorraine } \\
\text { Annexée. }\end{array}$ & $\begin{array}{l}\text { Refined } \\
\text { in Sarre } \\
\text { district. }\end{array}$ & $\begin{array}{l}\text { Produced } \\
\text { in Sarre } \\
\text { district. }\end{array}$ \\
\hline 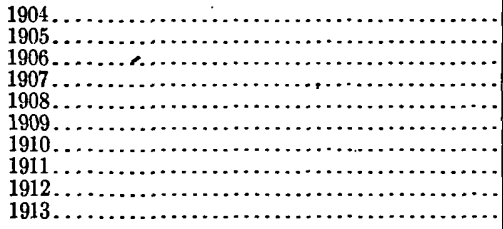 & $\begin{array}{r}752,770 \\
814,310 \\
901,252 \\
950,446 \\
1,025,550 \\
1,132,344 \\
1,197,688 \\
1,219,700 \\
1,300,662 \\
1,374,534\end{array}$ & $\begin{array}{r}6,398 \\
6,920 \\
7,660 \\
8,080 \\
8,717 \\
9,560 \\
10,175 \\
10,355 \\
11,049 \\
11,674\end{array}$ & $\begin{array}{l}273,950 \\
296,420 \\
328,000 \\
346,000 \\
373,200 \\
412,000 \\
435,880 \\
443,900 \\
473,210 \\
500,580\end{array}$ & $\begin{array}{l}1,020,222 \\
1,141,530 \\
1,221,592 \\
1,288,366 \\
1,390,039 \\
1,534,784 \\
1,623,393 \\
1,653,247 \\
1,762,823 \\
1,863,440\end{array}$ & $\begin{array}{l}1,138,600 \\
1,272,500 \\
1,351,200 \\
1,438,000 \\
1,560,000 \\
1,710,100 \\
1,810,000 \\
1,846,000 \\
1,961,800 \\
2,079,825\end{array}$ \\
\hline
\end{tabular}

\section{OWNERSHIP OF IRON AND STEEL PLANTS, COAL MINES, AND} COAL ILANDS.

The following paragraphs summarize the available information about the metallurgic companies in 1913:

GERMAN.

Roechlingsche Eisen und Stahlwerke. Capital, 25,000,000 francs. Owns seven blast furnaces with a capacity of 1,000 tons; one steel plant, with five Thomas converters of 22 tons; one electric furnace; one rolling mill; and one foundry.

Aktiengesellschaft der Dillinger Hüttenwerke. Capital, 21,100,000 francs. Owns five blast furnaces with a total daily capacity of 1,000 tons; one steel plant with two Thomas converters of 15 tons and one of 20 tons; also three Martin furnaces of 15 tons, two of 20 tons, one of 25 tons, two of 50 tons, and one of 60 tons; rolling mill; and a case-hardening armor-plate plant.

Gebrüder Stumm. : Capital, 27,000,000 francs. Owns six blast furnaces with a total daily capacity of 800 tons, one steel plant with four 25-ton Thomas converters and one 5-ton Martin furnace, four electric furnaces, one rolling mill, ten puddling furnaces, and one foundry.

Rud. Bocking et Cie., of Halberger Hütte. Capital, unknown. Owns five furnaces, with a daily capacity of 10,000 tons, and two foundries.

Mannesmann Rohrenwerke. Capital, 90,000,000 francs. Owns two steel plants, with one Martin furnace of 5 tons, two of 18 tons, four of 25 tons, and two of 30 tons; one electric furnace; and one tube mill.

\section{GERMAN AND BELGIAN.}

Société des hauts fourneaux et aciéries de Rumelange et St. Ingbert. Capital, $7,500,000$ francs. Owns one steel plant, with three Thomas converters, and one rolling mill. The dominating capital in this company is German. 
GERMAN, FRENCH, AND LUXEMBURGIAN.

Aciéries réunies de Burbach, Eich, Dudelange. Capital, 75,000,000 francs. Owns eight blast furnaces, with a total daily capacity of 1,200 tons, two steel plants, with five 25-ton Thomas converters and three 20-ton Martin furnaces, and rolling mills. This company is probably dominated by German capital.

The total value of the iron and steel plants of the Sarre district is estimated from the annual production to be 500,000,000 francs. Of this aggregate the French, Belgian, and Luxemburgian interests represent about 75,000,000 francs, leaving 425,000,000 francs for the value of the German corporate interests. The following tables present a summary of the facts relating to the value of German and other ownership in the metallurgic plants, as well as in the coal industry:

Ownership and production of blast furnaces and steel plants in the Sarre district, 1913.

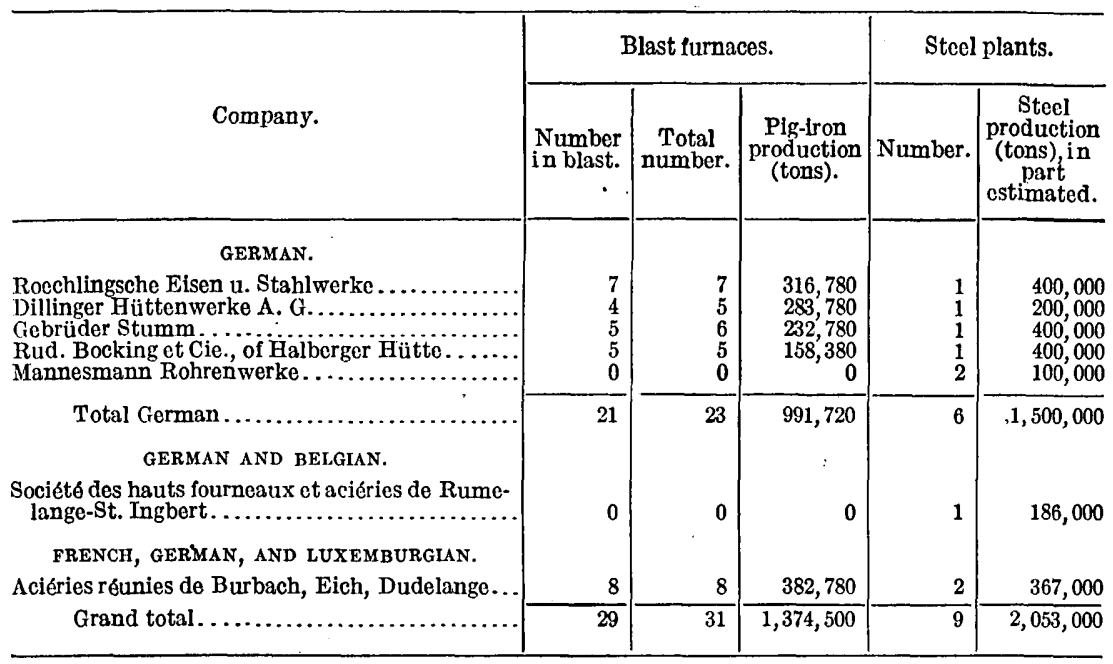

Estimated value of German interests in Sarre coal lands and coal mines, 1918, in francs.

[Coal lands, 1,200 francs per hectare; coal mines, 12 francs per ton of annual production; coke ovens, Prussian Government: 30,000 francs each.]

Coal lands....................... 120,000, 000

Coal mines and equipment. . ......... 160,000,000

Coke plants.................... 20,000,000

Bavarian Government: $300,000,000$

Coal lands...................... $5,000,000$

Coal mines and equipment........... 6,000,000

Private coal and coke companies (French and $11,000,000$ German):

Coal lands....................... 50,000,000

Coal mines and equipment. . ......... 44,000,000

Coke plants...................... $\frac{36,000,000}{130,000,000}$

Less French interests............... 30,000,000 
The data on the metallurgic companies given above can be summarized as follows: Seven companies, with an aggregate capitalization of about $270,000,000$ francs, own 9 steel plants and 31 blast furnaces. Of these 5 companies (capital about 180,000,000 francs) are entirely German. The other 2 (capital, 83,000,000 francs) are of mixed ownership. The details in regard to the German ownership of coal mines and lands and coking plants are discussed in earlier sections and are summarized in the following table:

Estimated value of German holdings in the Sarre district, 1919, in francs.

\begin{tabular}{|c|c|c|}
\hline & Private. & Government. \\
\hline \multirow[t]{3}{*}{$\begin{array}{l}\text { Iron and steel plants. } \\
\text { Coal mines, coal lands, and coke plants.. }\end{array}$} & $\begin{array}{l}425,000,000 \\
100,000,000\end{array}$ & $311,000,000$ \\
\hline & $525,000,000$ & $311,000,000$ \\
\hline & \multicolumn{2}{|c|}{$836,000,000$} \\
\hline
\end{tabular}

BELGIUM.

By Morrị F. LA Croix.

INTRODUCTION.

In 1913 the Belgian iron and steel industry was capitalized at approximately $350,000,000$ francs and turned out 300,000 tons of iron products and $2,000,000$ tons of steel products at a total profit of about $65,000,000$ francs.

The capacity and production of the iron and steel plants practically doubled during the pre-war decade. This expansion began toward the end of 1908 and was uninterrupted to the outbreak of the war. The rapid growth of this industry was due primarily to four conditions-the excellent quality and large quantity of the coal and coke produced in the Sambre and Meuse valleys of Belgium; the favorable location of the extensive Lorraine iron field with respect to these coals; the relatively favorable location of the Westphalian coal district with respect to the Belgian iron and steel plants; and the excellent systems of transportation, both rail and water, not only connecting the districts that provide the raw materials but affording cheap access to ocean ports.

The inability of Belgium to absorb the large amounts of iron and steel products necessitated the building up of a large export trade. This took approximately 80 per cent of the total iron and steel products manufactured in 1913.

The companies engaged in the Belgian iron and steel industry may be divided into three distinct groups. The largest group comprises companies operating or owning controlling interests in iron and coal mines, coke plants, blast furnaces, steel plants, and rolling mills and 
producing pig iron, crude and semifinished steel, and finished iron and steel products. In 1913 this group consisted of 19 companies or corporations operating 55 blast furnaces. These plants produced all the Belgian pig iron, amounting to 2,484,690 tons, 85 per cent of the crude steel, and 65 per cent of the finished steel products. They also produced 161,040 tons of forge and foundry iron.

This group represents the controlling interests and factors in the Belgian iron and steel industry and will therefore receive especial attention in this paper. The following table gives the principal statistics concerning the capitalization and production of these plants. In addition to the capital stock these companies had outstanding obligations amounting to about $85,000,000$-francs.

Belgian blast furnaces and steel plants in operation July 1, 1914.

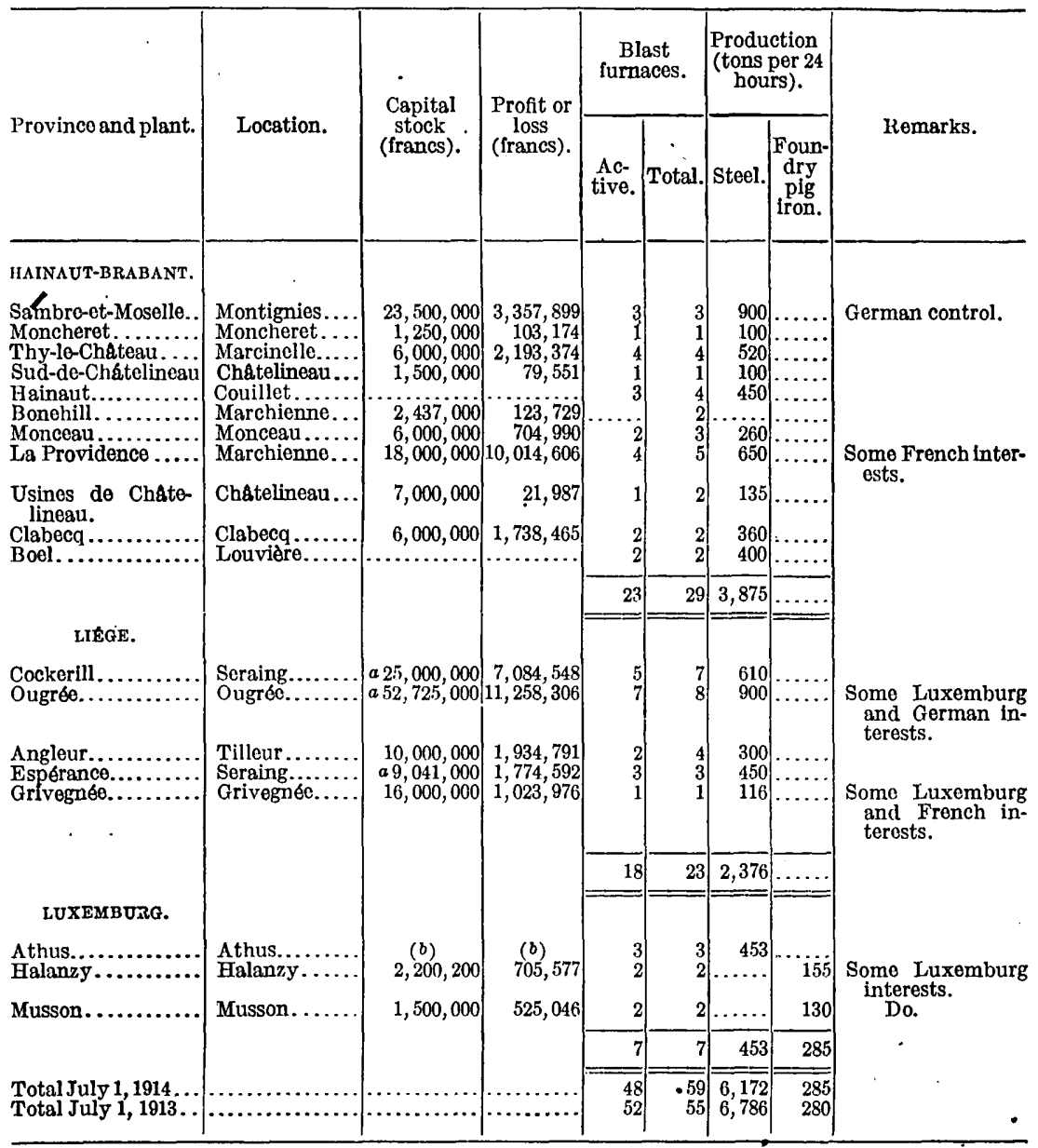

a No par value to capital stock.

$b$ Included in Grivegnée.

Note.-In 1913 one furnace of 85 tons daily capacity produced forge pig; no production in 1814. $187234^{\circ}-20-$ Bull. $703-6$ 
The second group includes companies that operate furnaces for the production of steel but depend upon the first group or foreign sources for their pig iron. In 1913 there were 11 of these companies. They produced 15 per cent of the crude steel and 11 per cent of the finished products. These with the 19 plants of the first group made a total of 30 steel-producing companies, of which 28 operated throughout the year 1913 .

The third group includes companies that buy pig iron and steel on the domestic market or from foreign sources and manufacture semifinished and finished iron and steel products. This group was represented by 38 companies in 1913. They produced the principal part of the puddled and forge iron and finished iron products and manufactured 24 per cent of the finished steel products.

\section{COST OF RAW MATERIALS.}

The total tonnage and cost at the plant of the raw materials consumed in the Belgian iron and steel industry for 1913 are estimated as follows:

Raw materials consumed in Belgian iron and steel industry, 1913.

\begin{tabular}{|c|c|c|c|}
\hline & \multirow{2}{*}{$\begin{array}{l}\text { Quantity } \\
\text { (tons). }\end{array}$} & \multicolumn{2}{|c|}{ Cost (francs). } \\
\hline & & Per ton. & Total. \\
\hline \multirow[t]{2}{*}{ 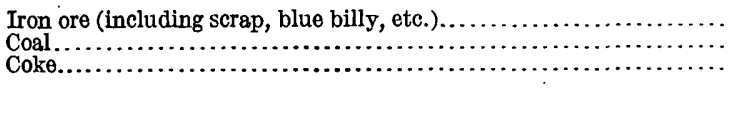 } & \multirow[t]{2}{*}{$\begin{array}{l}7,235,970 \\
1,197,990 \\
2,754,880\end{array}$} & \multirow[t]{2}{*}{$\begin{array}{l}10.0 \\
18.0 \\
25.0\end{array}$} & $\begin{array}{l}72,235,970 \\
21,563,800 \\
68,872,000 \\
\end{array}$ \\
\hline & & & $162,671,770$ \\
\hline
\end{tabular}

It was necessary to import 95 per cent of the iron ore and 22 per cent of the coal and coke, consumed by the iron and steel plants. Of the imported iron ore 90 per cent came from Luxemburg and French Lorraine (Briey district), and of the imported coal and coke 70 per cent came from the Westphalian district. In addition, Belgium imported during this year 578,408 tons of pig iron and 81,550 tons of steel ingots, blooms, and billets, also scrap and semifinished iron products. The total value of the imported material used in the manufacture of finished iron and steel products approximated $55,000,000$ francs.

The total number of workmen employed in the blast furnaces, steel plants, rolling mills, forges, foundries, and shops during 1913 was 35,300 . They received approximately $85,000,000$ francs in wages and salaries.

\section{QUANTITY AND VALUE OF PRODUCT.}

The output of crude, semifinished, and finished steel products during 1913 is estimated as follows: 
Output of pig iron, crude steel, and finished iron and steel products in Belgium, 1919.

\begin{tabular}{|c|c|c|c|}
\hline & \multirow{2}{*}{$\begin{array}{l}\text { Quantity } \\
\text { (tons). }\end{array}$} & \multicolumn{2}{|c|}{ Value (francs). } \\
\hline & & Per ton. & Total. \\
\hline Pig iron.... & $2,484,690$ & \multirow[t]{2}{*}{73.80} & a $183,336,450$ \\
\hline 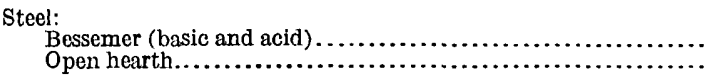 & $\begin{array}{r}2,192,180 \\
212,600 \\
\end{array}$ & & …............. \\
\hline Total steel (not including castings).. & $2,404,780$ & 95.0 & $228,106,900$ \\
\hline \multirow[t]{2}{*}{ 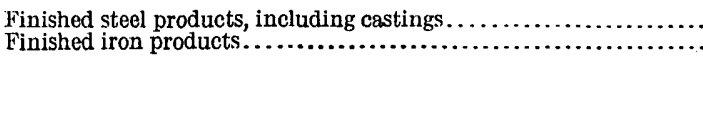 } & \multirow[t]{2}{*}{$\begin{array}{r}1,919,710 \\
304,350\end{array}$} & \multirow{2}{*}{$\begin{array}{r}147.20 \\
143.30\end{array}$} & $\begin{array}{r}282,483,350 \\
43,614,200\end{array}$ \\
\hline & & & $326,097,550$ \\
\hline
\end{tabular}

a 90 per cent of this value is included in the steel.

Belgium exported in 1913 pig iron and crude and semifinished steel products having an estimated value of $24,000,000$ francs. This with the value of finished steel and iron products turned out by the Belgian iron and steel plants, gives an approximate value of $350,000,000$ francs for the total product.

\section{PROFITS, CAPITAL, AND REAL VALUE.}

The annual profits of the companies and corporations engaged in the manufacture of iron and steel and finished products in Belgium are estimated at $65,000,000$ francs. This figure includes profits derived from iron and coal mines, coking plants, and allied industrial projects operated or controlled by the iron or steel producers.

The amount of capital invested in this industry in July, 1914, amounted to approximately $350,000,000$ francs, of which $250,000,000$ francs was represented by capital stock and 100,000,000 francs by other outstanding obligations. The 19 companies producing the pig iron and 85 per cent of the steel were capitalized at approximately $200,000,000$ francs and carried $85,000,000$ francs in outstanding bonds and other obligations.

These figures, however, give no measure of the real value of the properties which were operated by the Belgian iron and steel producers or in which they had ownership at the outbreak of the war. A considerable percentage of the earnings has been used for the purchase and development of iron and coal mines, coking plants, mills, and foundries and for new construction and development called for by the tremendous expansion of the iron and steel industry, especially during the years 1908 to 1913 , inclusive.

The value of the real property owned or controlled by the iron and steel producers in 1914 is estimated at $750,000,000$ francs. This includes holdings in iron mines and concessions in French Lorraine and Luxemburg, coal mines, coking plants, and subsidiary manufacturing companies in Belgium. 


\section{VALUE OF GERMAN INTERESTS.}

The facts at hand make it impossible to determine accurately the amount or value of the German ownership in the Belgian iron and steel industry prior to the war. The Sambre et Moselle company, operating three blast furnaces, steel furnaces, mills, etc., and five smaller plants, two of which represented the principal manufactories of small arms and ammunition in Belgium, were controlled by German interests. The Rondange division of the Société d'Ougrée-Marihaye sold its product of approximately 125,000 tons a year through the Stahlwerks Verband. There were other scattered holdings.

The capital stock held in 1914 by German interests is estimated at $60,000,000$ francs, representing 17 per cent of the total capital value. The total real value of the German holdings is estimated at $125,000,000,000$ francs.

\section{PRODUCTION AND SOURCES OF IRON ORE.}

The iron ore produced in Belgium supplied but a small percentage of her requirements during the pre-war decade, and the consumption of domestic ore decreased from 137,950 tons in 1904 to 84,900 tons in 1913. The latter figure represented little more than 1 per cent of the requirements for that year-in fact, the total output of the Belgian iron mines, 150,450 tons, of which 65,550 tons was exportedwould have supplied but 2.2 per cent of the requirements.

Iron ore produced in Belgium, 1913.

\begin{tabular}{|c|c|c|}
\hline Province. & $\begin{array}{c}\text { Quantity } \\
\text { (tons). }\end{array}$ & $\begin{array}{l}\text { Value } \\
\text { (francs } \\
\text { per ton). }\end{array}$ \\
\hline \multirow[t]{2}{*}{ 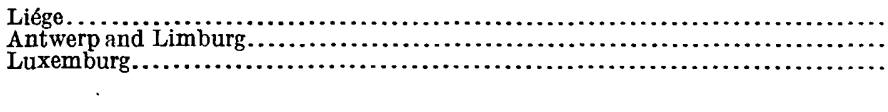 } & $\begin{array}{l}28,810 \\
48,320 \\
73,320 \\
\end{array}$ & $\begin{array}{r}11.62 \\
3.34 \\
3.34 \\
\end{array}$ \\
\hline & 150,450 & a 741,250 \\
\hline
\end{tabular}

a Total value.

The ore produced in the Liége district commands a high price because of its desirability as a mixing ore.

The mines included 61 open-pit mines, employing 187 miners, and three underground mines, employing 184 miners.

The reserves of iron ore in Belgium have been estimated as follows:

Iron-ore reserves of Belgium, 1913.a

\begin{tabular}{|c|c|c|}
\hline District. & $\begin{array}{l}\text { Quantity } \\
\text { (tons). }\end{array}$ & Character. \\
\hline \multirow{2}{*}{ 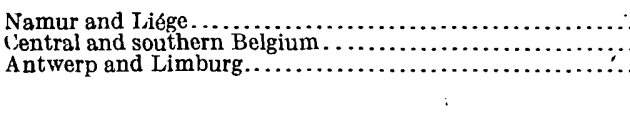 } & $\begin{array}{r}50,000,000 \\
4,500,000 \\
7,500,000 \\
\end{array}$ & \multirow[t]{2}{*}{$\begin{array}{l}\text { Sedimentary hematite. } \\
\text { Fissure veins, gossan, limonito. } \\
\text { Surface limonite. }\end{array}$} \\
\hline & $62,000,000$ & \\
\hline
\end{tabular}

$a$ Roesler's figures on iron ( $\mathrm{Fe}$ ) in the total Belgian ore reserves are as follows: Know n, 2,500,000 tons; probable, $14,100,000$ tons; possible, $23,200,000$ tons. See Roesler, Max, The iron-ore resources of Europe:
U. S. Geol. Survey Bull. 706 (in press). 
These reserves can only be regarded as ultimate, as they can not compete in the open market under present conditions or under those of the near future with the ore produced in the Loiraine field. A very small portion of that field is within the boundaries of Belgium, and ore reserves in this portion are estimated at 525,000 tons.

\section{IMPORTS.}

By far the largest percentage of iron ore smelted in Belgium is imported from French Lorraine. Belgium must continue to import these ores in constantly increasing amounts as the iron and steel industry expands. Prior to 1909 the larger proportion was imported from Luxemburg, but since that year imports from the French ironore districts have rapidly increased, so that in 1913 the ore imported from France was approximately four times that coming from Luxemburg. This ratio will continue to increase not only because of economic conditions, but also becausa of the fact that when the last large iron-ore concessions were made in Luxemburg exportation of the ore from them was prohibited.

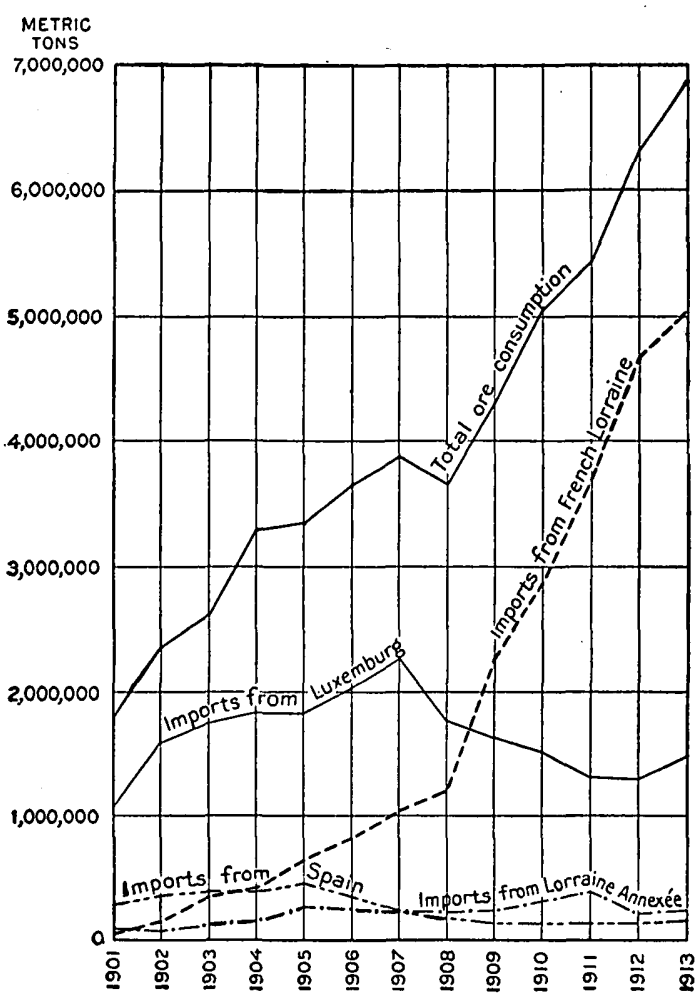

FIGURE 9.-Consumption and imports of iron ore in Belgium, 1901-1913.

The importation of ore from Lorraine Annexée has never been large and has fluctuated but slightly since 1905. It supplies but a small percentage of the total requirements.

Iron scrap, slags rich in ore, and the residue of pyrite roasting (blue billy), aggregating 5 to 6 per cent of the annual iron-ore requirements, are a small addition to the requirements of the blast furnaces. In 1913 the total quantity of such material smelted was 375,840 tons.

The table following and figure 9 give the pre-war statistics showing the sources of the iron ore smelted in Belgium. 
Iron ore smelted in Belgium, 1904-1918, by sources, in tons.

\begin{tabular}{|c|c|c|c|c|c|c|c|}
\hline \multirow{2}{*}{ Year. } & \multirow{2}{*}{$\begin{array}{c}\text { Belgian } \\
\text { pro- } \\
\text { duction. }\end{array}$} & \multicolumn{5}{|c|}{ Imports. } & \multirow{2}{*}{$\begin{array}{l}\text { Total } \\
\text { consump- } \\
\text { tion. }\end{array}$} \\
\hline & & $\begin{array}{c}\text { French } \\
\text { Lorraine. }\end{array}$ & $\begin{array}{c}\text { Luxem- } \\
\text { burg. }\end{array}$ & $\begin{array}{l}\text { Lorraine } \\
\text { Annexée. }\end{array}$ & Spain. & Total. & \\
\hline 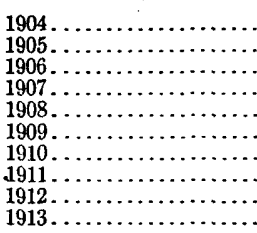 & $\begin{array}{l}137,950 \\
133,150 \\
127,550 \\
129,170 \\
146,430 \\
199,710 \\
122,960 \\
150,500 \\
167,370 \\
150,450\end{array}$ & $\begin{array}{r}405,870 \\
644,680 \\
816,750 \\
1,025,600 \\
1,188,400 \\
2,261,490 \\
2,885,230 \\
3,567,000 \\
4,579,300 \\
5,000,000\end{array}$ & $\begin{array}{l}1,831,000 \\
1,829,000 \\
2,026,000 \\
2,259,000 \\
1,759,000 \\
1,625,000 \\
1,519,000 \\
1,300,000 \\
1,290,600 \\
1,380,000\end{array}$ & $\begin{array}{l}133,000 \\
264,000 \\
232,000 \\
207,000 \\
201,000 \\
228,000 \\
303,000 \\
379,000 \\
206,000 \\
237,000\end{array}$ & $\begin{array}{l}382,000 \\
450,000 \\
330,000 \\
206,000 \\
180,000 \\
126,000 \\
136,000 \\
142,000 \\
146,000 \\
158,000\end{array}$ & $\begin{array}{l}3,134,855 \\
3,190,150 \\
3,548,180 \\
3,699,750 \\
3,408,650 \\
4,401,540 \\
4,978,610 \\
5,388,080 \\
6,221,900 \\
6,775,230\end{array}$ & $\begin{array}{l}2,374,820 \\
2,870,830 \\
3,202,300 \\
2,412,770 \\
2,294,830 \\
\mathbf{4}, 314,200 \\
\mathbf{5}, 062,830 \\
\mathbf{5}, 442,550 \\
\mathbf{6}, 311,850 \\
\mathbf{6 ,} 860,130\end{array}$ \\
\hline
\end{tabular}

NOTE.-From 40 to 50 per cent of the Belgian output was exported. Small amounts of hematite ore have been imported at different times from England.

\section{COAL FIELDS.}

\section{GEOGRAPHIC DISTRIBUTION.}

The greater part of the coal used in the iron and steel industry of Belgium is produced within her own boundaries. There are two areas in which coal occurs. The southern area, known as the HaineSambre-Meuse Basin, is a continuation of the Bassin du Nord of France and passes through Belgium into Prussia (Aix-la-Chapelle field). This basin has been the productive area in the past. The northern or Campine Basin is an entirely separate area and up to 1913 had produced no coal.

The following table shows the geographic distribution (see Pl. I) and the kinds of coal produced in the subdivisions of these basins:

Belgian coal basins.

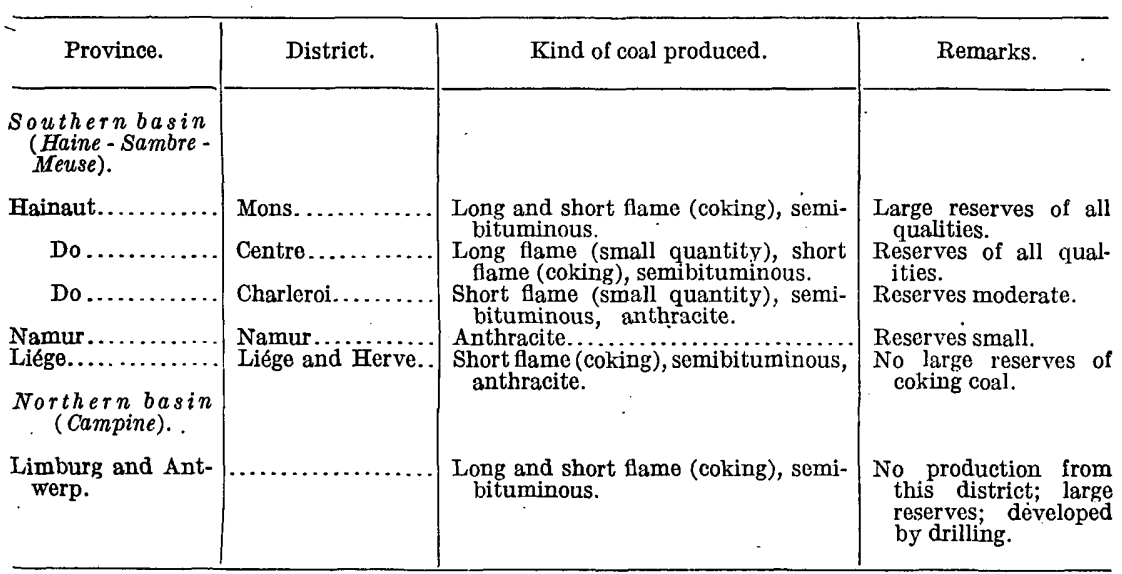

\section{HAINE-SAMBRE-MEUSE BASIN.}

The Haine-Sambre-Meuse Basin passes through the center of the Province of Hainaut, the northern part of Namur, and the central part of Liége. The coal measures of this basin have a length of about 170 kilometers within the territorial limits of Belgium, form- 
ing a belt from 3 to 15 kilometers wide. All the coal mined in Belgium comes from this basin, or from the small detached bodies of coal lying immediately to the south of it. Most of the coal beds are much folded and faulted.

\section{PROVINCE OF HAINAUT,}

The Province of Hainaut contains three groups of mines.

MONS DISTRICT.

The Mons district (couchement de Mons du Borinange) lies between the French frontier and the city of Mons. During the year 1913 there were 24 operating companies in the district, mining through 64 shafts. About 15 mines have been abandoned, owing both to exhaustion of the reserves and to the difficulties of deep mining-that is, below a depth of 1,200 meters.

The average thickness of the coal seams mined is about 55 centimeters and the maximum thickness rarely exceeds 1.70 meters.

The output of this district consists of long-flame coking and bituminous coals. It produces no anthracite.

CENTER DISTRICT.

The Center district (bassin du centre) lies between Mons and Charleroi, bounded on the north by the Brussels Canal and on the south by Sambre River. During 1913 there were 11 companies operating in this district through 33 shafts. The average thickness of the beds mined was 65 centimeters, and the average depth of mining about 450 meters. The production of long-flame coal has ceased in this district. Short-flame (coking) and semibituminous coals only are produced. The development of these coals and the tonnage of the present production could be considerably increased. Small bodies of anthracite coal appearing close to the surface have not been mined.

CHARLEROI DISTRICT.

The Charleroi district extends from the city of Charleroi to the eastern boundary of the Province of Hainaut. During 1913 there were 35 operating companies and 84 active shafts in this district.' A few of the shafts have reached a depth of 1,000 meters, but the average depth of mining is about 550 meters. The average thickness of the beds mined is 70 centimeters. The product of this district is varied. Near Charleroi short-flame coking and semibituminous are produced. In the eastern part of the basin anthracite coal is mined. South of Sambre River coking and forge coals are produced.

PROVINCE OF NAMUR.

The coal basin is comparatively narrow in the Province of Namur, and its depth is less here than it is in either the Hainaut or the Liége district. In 1913 there were 12 operating companies and 17 active shafts in the Namur district. The average thickness 
of the coal seams was 75 centimeters, and the product a low-grade semibituminous or anthracite coal.

\section{PROVINCE OF LIEGE.}

The Liége district extends from the western to the eastern limits of the Province. The coal measures continue into the Aix-la-Chapelle field of Rheinland. The Liége district is second in importance to the Mons district, having had 43 operating companies and 74 active shafts in 1913. The average depth of mining was 450 meters, and the averge thickness of coal seam 60 centimeters. The coal beds range from 0.45 to 1.80 meters in thickness. The product of this district consists of short-flame (coking) semibituminous and anthracite coals. There has been a steady decline in the production of coking coal throughout this district, and the developed reserves in the mines are rapidly becoming exhausted.

\section{CAMPINE BASIN.}

The Campine Basin was discovered in 1901 and has been developed by drilling. The coal measures of this basin underlie the northcentral part of the Province of Limburg and have been traced into the central part of the Province of Antwerp. The known length of the basin from northwest to southeast is about 90 kilometers, and its width ranges from 12 to 16 kilometers.

The entire coal-bearing formation is covered by an overburden ranging in thickness from 370 meters in the southeastern part of the basin to more than 1,000 meters along the northern extremity, in Limburg, and the western extremity in the Province of Antwerp. The overburden contains water-soaked strata, which will make the development of these coal measures difficult.

In 1913 six companies were engaged in sinking 12 shafts, but up to the outbreak of the war none of these shafts had been bottomed. This work progressed slowly and was greatly hampered by the inflow of water from several water-bearing strata. Work was continued during the period of German occupation after conditions behind the lines began to stabilize, and early in 1919 several of these mines began to produce a little coal.

The thickness of the beds ranges in general from 0.40 to 1 meter. A few beds having a thickness of 1.75 meters and one of 2.20 meters have been found. The drill logs show the beds to be very regular and persistent, but the vertical distance between them varies considerably. The inclination of the beds ranges from a few degrees to $35^{\circ}$.

The coal found in this basin includes all grades from an anthracite or semibituminous coal containing about 11 per cent of volatile matter to a long-flame coal containing over 25 per cent and often as high 
as 40 per cent of volatile matter, with a low ash content. The coal in this basin represents approximately 70 per cent of the total estimated Belgian reserves.

COAL RESERVES.

The exploitable coal reserve of the Haine-Sambre-Meuse Basin amounts to $3,000,000,000$ tons. This coal is all found above a depth of 1,200 meters. By far the largest percentage of it is in the western part of the province of Hainaut, near the French frontier, in the north-central part of the Mons Basin, and in the central basin of the Hainaut district. The percentage of coking coals in this region is large.

There are no significant reserves of coking coal east of Charleroi or in the Liége district.

The amount of reserves in the small isolated basins lying along and to the south of the main basin add but a small tonnage to the total.

The Campine Basin has a reserve developed by drilling of 4,000 ,000,000 tons above a depth of 1,000 meters, and of $8,000,000,000$ tons above a depth of 1,500 meters.

The following table shows the location and quality of the estimated Belgian reserves. The minimum thickness of the beds included in the estimate ranges from 30 to 50 centimeters, depending upon the quality of coal and the depth of the seam.

Belgian coal reserves, in tons. ${ }^{a}$

\begin{tabular}{|c|c|c|c|c|}
\hline Province. & $\begin{array}{l}\text { Long-flame; } \\
\text { over } 25 \text { per } \\
\text { cent of vola- } \\
\text { tile matter. }\end{array}$ & $\begin{array}{l}\text { Coking; } 16 \\
\text { to } 25 \text { per cent } \\
\text { of volatile } \\
\text { matter. }\end{array}$ & $\begin{array}{l}\text { Somibitumi- } \\
\text { nous and an- } \\
\text { thracite. }\end{array}$ & Remarks. \\
\hline Haine-Sambre-Meuse Basin. & \multirow{3}{*}{$500,000,000$} & & 2 & \multirow{4}{*}{$\begin{array}{l}\text { Above a depth of } 1,200 \\
\text { meters. } \\
\text { Do. }\end{array}$} \\
\hline Hainaut... & & $1,000,000,000$ & $900,000,000$ & \\
\hline Liégo and Namur. & & $100,000,000$ & $500,000,000$ & \\
\hline Campine Basin. & \multirow{3}{*}{$3,600,000,000$} & & $\backslash$ & \\
\hline Ljmburg. & & $2,900,000,000$ & $500,000,000$ & \multirow{3}{*}{$\begin{array}{l}\text { Above a depth of } 1,500 \\
\text { meters. } \\
\text { Do. }\end{array}$} \\
\hline Antwerp.. & & $1,000,000,000$ & $\ldots \ldots$ & \\
\hline . & $4,100,000,000$ & $5,000,000,000$ & $1,900,000,000$ & \\
\hline
\end{tabular}

a In a manuscript report entitled "Coal and coke in Europe," by Eugene Stebinger, the total Belgian coal reserves are given as "known, 2;500,000,000 tons; probable, 8,500,000,000 tons." This tabıe includes both of theso classes of reserves.

\section{COAL PRODUCTION.}

The Belgian coal production for the 10-year period prior to the war was approximately $23,000,000$ tons a year, showing during this period the fluctuations narmal to general business and economic conditions. 
The amount of long-flame coal, produced only in the Mons and Center districts of Hainaut, showed a decline in the annual production of 300,000 tons, or 14 per cent, from 1904 to 1913.

The production of short-flame coking coals also decreased, particularly in the Liége districts, where the amount of developed reserve is becoming exhausted. The total decrease in the output for the 10-year period was approximately 500,000 tons, or 9 per cent of the production in 1913.

The production of semibituminous coals remained constant at approximately $10,000,000$ tons a year. The annual production of anthracite increased from 1904 to 1913 by 1,500,000 tons, or 27 per cent of the 1913 production. This increase in production was due to increases both in the Charleroi and Liége districts. About 70 per cent of the coal of this quality is produced in the Charleroi district.

The number of operating mines fluctuated between 121 and 127 during the 10-year pre-war period, but the number of shafts decreased from 335 to 305 . In 1913 about 20 shafts formerly reported as "reserve" were definitely reported as abandoned.

Statistics of Belgian coal industry, 1904-1913.

\begin{tabular}{|c|c|c|c|c|c|c|}
\hline \multirow[b]{2}{*}{ Year. } & \multirow[b]{2}{*}{ Mines $a$} & \multirow[b]{2}{*}{$\begin{array}{c}\text { Hoisting } \\
\text { shafts. } b\end{array}$} & \multicolumn{4}{|c|}{ Production (tons). } \\
\hline & & & \multicolumn{2}{|c|}{$\begin{array}{l}\text { Long-flame; } \\
\text { more than } \\
25 \text { per cent } \\
\text { of volatile } \\
\text { matter. }\end{array}$} & \begin{tabular}{|} 
Short-flame; \\
from 25 \\
to 16 per \\
cent of vol- \\
atile mat- \\
ter.
\end{tabular} & $\begin{array}{l}\text { Semibitu- } \\
\text { mincus; } \\
\text { from } 16 \text { to } \\
11 \text { per cent } \\
\text { of volatile } \\
\text { matter. }\end{array}$ \\
\hline 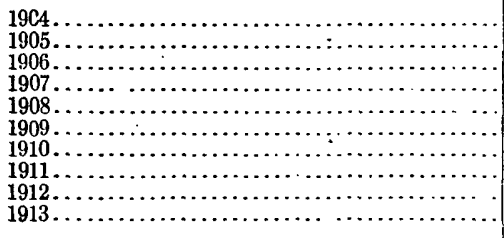 & $\begin{array}{l}122 \\
121 \\
122 \\
125 \\
124 \\
122 \\
125 \\
127 \\
126 \\
125\end{array}$ & $\begin{array}{l}355 \\
328 \\
338 \\
343 \\
340 \\
331 \\
329 \\
319 \\
325 \\
305\end{array}$ & & $\begin{array}{l}409,970 \\
287,390 \\
499,600 \\
454,660 \\
320,330 \\
243,210 \\
255,590 \\
387,800 \\
098,220 \\
110,790\end{array}$ & $\begin{array}{l}948,070 \\
741,990 \\
772,460 \\
992,500 \\
914,170 \\
28,280 \\
181,350 \\
859,550 \\
691,580 \\
453,620\end{array}$ & $\begin{array}{r}10,492,250 \\
v, 719,440 \\
10,590,400 \\
10,215,420 \\
10,315,710 \\
10,268,100 \\
10,291,380 \\
9,631,010 \\
10,044,320 \\
9,715,610\end{array}$ \\
\hline \multirow[b]{2}{*}{ Year. } & & \multicolumn{3}{|c|}{ Production (tons). } & \multirow[b]{2}{*}{$\begin{array}{l}\text { Cost of } \\
\text { mining } \\
\text { per ton } \\
\text { (francs). }\end{array}$} & \multirow[b]{2}{*}{\begin{tabular}{|l|l} 
& Mean \\
value \\
per ton \\
(francs).
\end{tabular}} \\
\hline & & \multicolumn{2}{|c|}{$\begin{array}{c}\text { Anthracite; } \\
\text { less than 11 } \\
\text { per cent of } \\
\text { volatile } \\
\text { matter. }\end{array}$} & Total. & & \\
\hline $\begin{array}{l}1904 \ldots . \\
1905 \ldots . \\
1906 \ldots \\
1907 \ldots . \\
1908 \ldots \\
1909 \ldots \\
1910 \ldots \\
1911 \ldots \\
1912 \ldots \\
1913 \ldots\end{array}$ & & \multicolumn{2}{|c|}{$\begin{array}{l}3,911,140 \\
4,026,460 \\
4,507,400 \\
4,942,610 \\
5,007,690 \\
4,977,960 \\
5,188,340 \\
3,175,180 \\
5,138,020 \\
5,561,570\end{array}$} & $\begin{array}{l}22,761,430 \\
21,775,280 \\
23,569,860 \\
23,705,190 \\
23,557,900 \\
23,517,550 \\
23,916,560 \\
23,053,540 \\
22,972,140 \\
22,811,590\end{array}$ & $\begin{array}{l}11.84 \\
11.81 \\
13.09 \\
14.70 \\
14.71 \\
13.63 \\
14.09 \\
14.90 \\
16.22 \\
17.51\end{array}$ & $\begin{array}{l}12.59 \\
12.64 \\
15.00 \\
16.86 \\
16.14 \\
14.37 \\
14.59 \\
14.76 \\
16.56 \\
18.34\end{array}$ \\
\hline
\end{tabular}

$a$ These do not include mines being developed in the province of Limburg and not producing. $b$ Total shafts, active, reserve, and being sunk. 
The total number of workmen employed in the coal-mining industry in 1913 was as follows:

Miners underground $\ldots \ldots \ldots \ldots \ldots \ldots \ldots \ldots \ldots \ldots \ldots \ldots \ldots \ldots \ldots \ldots \ldots \ldots \ldots, 844$

Muckers, trammers, repair men, etc................... 80, 957

Workmen, surface $\ldots \ldots \ldots \ldots \ldots \ldots \ldots \ldots \ldots \ldots \ldots \ldots \ldots \ldots \ldots \ldots \ldots \ldots, 536$

145,337

The average number of days of work in 1913 was 298 .

The average annual production per workman has shown a marked decrease in the Namur district since 1904. In 1913 it was as follows:

Average annual coal production per mine and per workman in Belgium, 191s, in tons.

\begin{tabular}{|c|c|c|c|c|c|c|}
\hline & Mons. & Center. & Charleroi. & Namur. & Liége. & Average. \\
\hline $\begin{array}{l}\text { Per mine } \\
\text { Per man underground . } \\
\text { Per man underground and on the surface. }\end{array}$ & $\begin{array}{l}699 \\
181 \\
136\end{array}$ & $\begin{array}{l}868 \\
218 \\
158\end{array}$ & $\begin{array}{r}1,063 \\
244 \\
170\end{array}$ & $\begin{array}{l}925 \\
230 \\
174\end{array}$ & $\begin{array}{r}1,000 \\
210 \\
156\end{array}$ & $\begin{array}{l}919 \\
216 \\
157\end{array}$ \\
\hline
\end{tabular}

The average daily wage for all classes of workmen in 1913 was 5.17 francs.

Of the 126 mines operated in 1913,75 showed a total profit of 33,905,100 francs; 51 mines showed a loss of 14,960,050 francs.

Cost, average value, and profit per ton of coal mined in Belgium, 1906-1910, 1912, and 1919.

\begin{tabular}{|c|c|c|c|c|c|c|}
\hline \multirow[b]{2}{*}{. } & \multicolumn{2}{|c|}{$1906-1910$} & \multicolumn{2}{|c|}{1912} & \multicolumn{2}{|c|}{1913} \\
\hline & Francs. & $\begin{array}{c}\text { Per cent } \\
\text { of aver- } \\
\text { age value. }\end{array}$ & Francs. & $\begin{array}{c}\text { Per cent } \\
\text { of aver- } \\
\text { age value. }\end{array}$ & Francs. & $\begin{array}{l}\text { Per cent } \\
\text { of aver- } \\
\text { age value. }\end{array}$ \\
\hline $\begin{array}{l}\text { Mining expense ................... } \\
\text { Maintenance and amortization. }\end{array}$ & $\begin{array}{r}12.81 \\
1.23\end{array}$ & $\begin{array}{r}83.13 \\
7.98\end{array}$ & $\begin{array}{r}14.24 \\
1.98\end{array}$ & $\begin{array}{l}85.98 \\
11.96\end{array}$ & $\begin{array}{r}15.54 \\
1.97\end{array}$ & $\begin{array}{l}84.73 \\
10.75\end{array}$ \\
\hline $\begin{array}{l}\text { Total cost.. } \\
\text { Average value... }\end{array}$ & $\begin{array}{l}14.04 \\
15.41\end{array}$ & $\begin{array}{r}91.11 \\
100.00\end{array}$ & $\begin{array}{l}16.22 \\
16.50\end{array}$ & .97 .94 & $\begin{array}{l}17.51 \\
18.34\end{array}$ & $\begin{array}{r}95.48 \\
100.00\end{array}$ \\
\hline Profit.. & 1.37 & 8.89 & .34 & 2.06 & .83 & 4.52 \\
\hline
\end{tabular}

COAL IMPORTS AND EXPORTS.

In the years prior to the war Belgium imported considerable coal. The imports more than doubled during the 10 years preceding the war and in 1913 were $8,856,153$ tons, or 39 per cent of the production. Approximately 20 per cent of this quantity, or 1,795,450 tons, was imported expressly for the manufacture of coke. This coal came almost entirely from the Westphalia and Aix-la-Chapelle districts of Germany. During the period 1910 to 1913 Germany rapidly increased her coal exports to Belgium from the Westphalia and Aixla-Chapelle fields, particularly from the former, which produced high-grade steaming and coking coals at a low cost.

The following table and figure 10 show the sources of the coal used in Belgium: 
Coal used in Belgium, 1904-1913, by sources, in tons.

\begin{tabular}{|c|c|c|c|c|c|c|c|}
\hline \multirow[b]{2}{*}{ Year. } & \multirow{2}{*}{$\begin{array}{l}\text { Produced } \\
\text { in } \\
\text { Belgium. }\end{array}$} & \multicolumn{5}{|c|}{ Imported. } & \multirow{2}{*}{$\begin{array}{c}\text { Con- } \\
\text { sumed. }\end{array}$} \\
\hline & & Germany. & France. & England. & $\begin{array}{c}\text { Other } \\
\text { countries. } a\end{array}$ & Total. & \\
\hline $\begin{array}{l}1904 . . \\
1905 . \\
1906 . \\
1907 . \\
1908 . \\
1909 . \\
1910 . \\
1911 . \\
1912 . \\
1913 .\end{array}$ & $\begin{array}{l}22,761,430 \\
21,775,280 \\
23,569,860 \\
23,705,190 \\
23,557,900 \\
23,517,550 \\
23,916,560 \\
23,053,540 \\
22,972,140 \\
22,841,590\end{array}$ & $\begin{array}{l}2,311,094 \\
2,539,485 \\
3,071,882 \\
3,699,596 \\
3,281,752 \\
3,803,161 \\
4,213,918 \\
4,686,700 \\
5,368,472 \\
5,728,406\end{array}$ & $\begin{array}{r}664,000 \\
1,152,000 \\
870,000 \\
639,000 \\
590,000 \\
622,000 \\
795,000 \\
856,000 \\
1,222,000 \\
811,000\end{array}$ & $\begin{array}{r}614,242 \\
680,280 \\
1,555,487 \\
1,766,498 \\
1,830,711 \\
1,718,322 \\
1,704,880 \\
1,945,455 \\
1,546,768 \\
2,031,077\end{array}$ & $\begin{array}{r}604,534 \\
497,619 \\
445,581 \\
424,498 \\
248,247 \\
184,187 \\
629,382 \\
1,092,145 \\
1,639,749 \\
285,670\end{array}$ & $\begin{array}{l}4,193,870 \\
4,769,284 \\
5,942,950 \\
5,899,590 \\
5,950,750 \\
6,327,670 \\
7,343,180 \\
8,580,300 \\
9,776,989 \\
8,856,153\end{array}$ & $\begin{array}{l}20,228,577 \\
20,991,347 \\
22,805,210 \\
23,242,620 \\
22,582,940 \\
23,754,770 \\
24,126,460 \\
24,844,660 \\
26,081,222 \\
26,046,094\end{array}$ \\
\hline
\end{tabular}

a The increases in the imports for 1911 and 1912 are probably due to shipments from Germany through Holland.

$b$ Production plus imports minus exports.

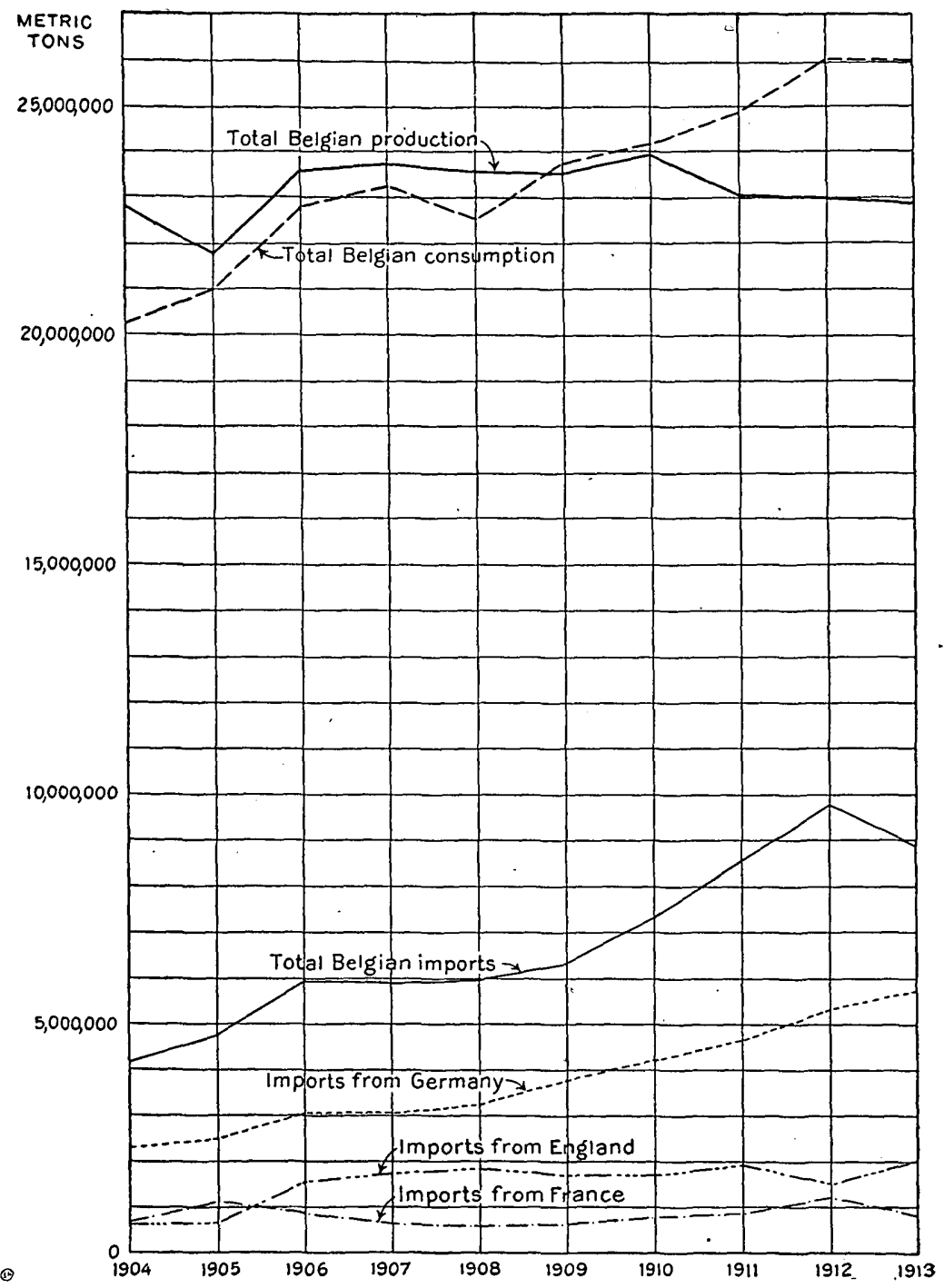

FIGURE 10.-Production, consumption, and imports of cosl in Belgium, 1904-1913. 
The increase in industrial requirements and the inability of the Belgian mines to produce at low cost sufficient coal of the grades suitable for metallurgic and other industrial purposes resulted in a large increase of imports over exports during the period from 1910 to 1913. Prior to 1910 the exports of combustibles (coal, coke, and briquets) exceeded the imports. The following table indicates the difference between exports and imports for the 10 years from 1904 to 1913 :

Excess of Belgian coal exports or imports, 1904-1913, in tons.

\begin{tabular}{|c|c|c|c|}
\hline \multirow{2}{*}{ Year. } & \multicolumn{2}{|c|}{ Excess. } & \multirow{2}{*}{$\begin{array}{l}\text { Total con- } \\
\text { sumption. }\end{array}$} \\
\hline & Exports. & Imports. & \\
\hline 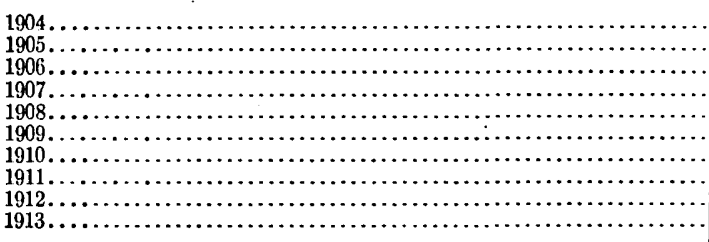 & 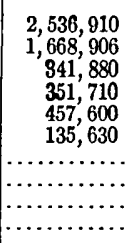 & 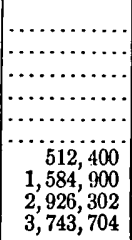 & $\begin{array}{l}20,228,577 \\
20,991,347 \\
22,805,210 \\
23,242,620 \\
22,582,940 \\
23,754,770 \\
24,126,460 \\
24,844,660 \\
26,081,222 \\
26,046,094\end{array}$ \\
\hline
\end{tabular}

PRODUCTION AND SOURCES OF COKE.

The coke-manufacturing plants of Belgium are in the Mons and Charleroi districts of the Province of Hainaut and in the Seraing district of the Province of Liége. In 1913 these plants represented 87 per cent of the total producing capacity-Hainaut 62 per cent and Liége 25 per cent. Of the coke works 13 per cent are outside of the large coal-producing areas and use imported coal almost entirely.

The following table shows the production of coke by provinces for 1913:

Statistics of coke production in Belgium, by districts, 1913.

\begin{tabular}{|c|c|c|c|c|}
\hline • & Hainaut. & Liége. & $\begin{array}{c}\text { Other } \\
\text { provinces. }\end{array}$ & Total. \\
\hline 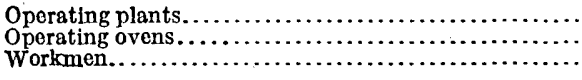 & $\begin{array}{r}28 \\
1,952 \\
2,600^{\circ}\end{array}$ & $\begin{array}{r}9 \\
648 \\
978 \\
\end{array}$ & $\begin{array}{r}4 \\
298 \\
651\end{array}$ & $\begin{array}{r}41 \\
2,898 \\
4,229 \\
\end{array}$ \\
\hline 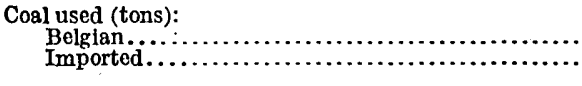 & $\begin{array}{r}2,277,870 \\
581,470 \\
\end{array}$ & $\begin{array}{r}524,430 \\
625,550 \\
\end{array}$ & $\begin{array}{r}4,000 \\
588,430 \\
\end{array}$ & $\begin{array}{r}2,806,300 \\
1,795,450 \\
\end{array}$ \\
\hline $\begin{array}{l}\text { Coke produced (tons) } \ldots \ldots \ldots \ldots \ldots \ldots \ldots \ldots \\
\text { Percentage of recovery } \ldots \ldots \ldots \ldots \ldots \ldots \ldots\end{array}$ & $\begin{array}{r}2,859,340 \\
2,200,180 \\
76.90\end{array}$ & $\begin{array}{r}1,149,980 \\
877,130 \\
76.30\end{array}$ & $\begin{array}{r}592,430 \\
445,690 \\
75.20\end{array}$ & $\begin{array}{r}4,601,750 \\
3,523,000 \\
76.6\end{array}$ \\
\hline
\end{tabular}

The production of coke increased steadily from 1904 up to the beginning of the war. In 1904 the output was 2,496,340 tons, and in 1913 it was $3,523,000$ tons, an increase of $1,026,660$ tons, or 41 per cent, during a period of 10 years. During this period the number of operating plants decreased from 45 to 41 and the number of ovens 
from 4,707 to 2,898 . The reduction in the number of ovens was due entirely to changes in the methods and technique of manufacturing, especially in the conservation of the by-products. The average yield in coke for the ovens in 1913 was 76.6 per cent of the coal consumed.

PRODUCTION AND IMPORTATION OF COKING COAL.

From 1904 to 1913 the annual domestic production of coking coal was insufficient to fill the demands, and coal was imported for this purpose in constantly increasing amounts each year. The percentage

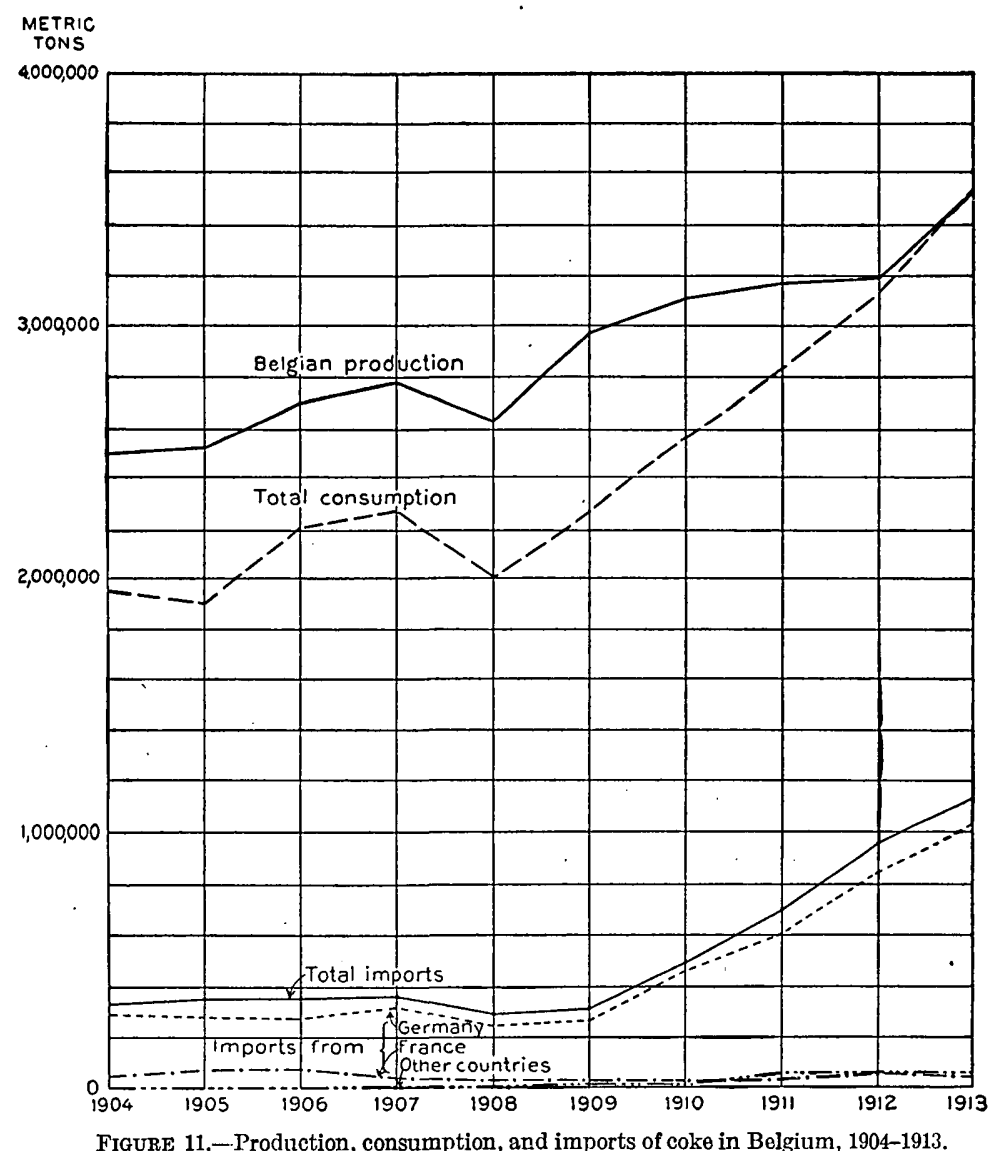

of foreign coal used in the manufacture of coke increased from 21 per cent in 1904 to 39 per cent in 1913. The principal source of this coal was the Westphalia field, but some came from the Aix-la-Chapelle field, and a very small quantity from England. Of the total coking coal imported in 1913, the Province of Hainaut consumed 32 per cent, Liége 35 per cent, and the coke plants operating outside of these coal-producing areas 33 per cent.

The production of coking coal in the Liége district was steadily decreasing prior to the war, and the cost of producing coking coal in 
the Mons district was increasing. This district can, however, continue to produce coking coal for a long period of years but in small quantities. The large undeveloped reserves of coking coal in the Campine Basin offer the only means of increasing the production of coal of this quality in Belgium. The development of this basin was started a few years before the war, and coal is now being produced in moderate quantities as development work continues. It will be a few years, however, before coal from this basin can be mined in any considerable quantity, and the cost of production will always be relatively high, owing to the great depth of mining (800 to 1,500 meters).

Some coking coal must be imported for the production of coke in Belgium during the next few years, at least. The two principal sources are England and the Westphalia and Aix-la-Chapelle districts of Germany. Coal from the Westphalia district will always be a factor in the Belgian coke industry, even if not essential, owing to its high quality and low cost of production as compared with the probable cost of producing coal in the Campine Basin.

The average value of Belgian coke has steadily increased from 19.44 francs a ton in 1904 to 27.28 francs in 1913.

The following table and figure 11 give the principal statistics of the Belgian coke production from 1904 to 1913, inclusive:

Statistics of coke production in Belgium, 1904-1913.

\begin{tabular}{|c|c|c|c|c|c|c|c|}
\hline Year. & $\begin{array}{l}\text { Operat- } \\
\text { ing } \\
\text { plants. }\end{array}$ & $\begin{array}{l}\text { Operat- } \\
\text { ing } \\
\text { ovens. }\end{array}$ & $\begin{array}{c}\text { Coal im- } \\
\text { ported for } \\
\text { manufac- } \\
\text { ture of coke } \\
\text { (tons). }\end{array}$ & $\begin{array}{l}\text { Per cent } \\
\text { of im- } \\
\text { ported } \\
\text { coal con- } \\
\text { sumed. }\end{array}$ & $\begin{array}{c}\text { Coal } \\
\text { consumed } \\
\text { (tons). }\end{array}$ & $\begin{array}{l}\text { Coke. } \\
\text { produced } \\
\text { (tons). }\end{array}$ & $\begin{array}{c}\text { Average } \\
\text { value } \\
\text { por tion } \\
\text { (francs). }\end{array}$ \\
\hline 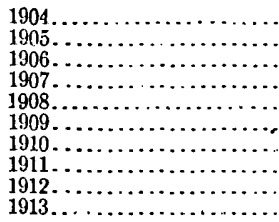 & $\begin{array}{l}45 \\
43 \\
42 \\
41 \\
41 \\
41 \\
40 \\
40 \\
38 \\
41\end{array}$ & $\begin{array}{l}4,707 \\
4,248 \\
3,967 \\
3,601 \cdot \\
3,631 \\
3,477 \\
3,134 \\
4,097 \\
2,766 \\
2,898\end{array}$ & $\begin{array}{r}a 650,000 \\
a 700,000 \\
a 758,170 \\
a 732,390 \\
a 850,470 \\
1,139,810 \\
1,184,760 \\
1,408,610 \\
1,498,160 \\
1,795,450\end{array}$ & $\begin{array}{l}21 \\
20 \\
21 \\
20 \\
24 \\
29 \\
29 \\
34 \\
36 \\
39\end{array}$ & $\begin{array}{l}3,324,680 \\
3,354,190 \\
3,585,030 \\
3,637,490 \\
3,491,480 \\
3,941,750 \\
4,097,030 \\
4,149,980 \\
4,166,400 \\
4,601,750\end{array}$ & $\begin{array}{l}2,496,340 \\
2,526,890 \\
2,713,760 \\
2,771,920 \\
2,632,890 \\
2,972,920 \\
3,110,820 \\
3,160,950 \\
3,186,780 \\
3,523,000\end{array}$ & $\begin{array}{l}19.44 \\
19.20 \\
23.60 \\
26.87 \\
24.78 \\
21.36 \\
21.10 \\
23.36 \\
25.38 \\
27.28\end{array}$ \\
\hline
\end{tabular}

a Estimated.

IMPORTS AND EXPORTS OF COKE.

The exports of coke have always exceeded the imports until 1913, when the trade balance was reversed and the imports exceeded the exports by the narrow margin of 14,408 tons. Belgium has always imported the largest percentage of her coke from Germany, which in 1913 supplied about 90 per cent of the total imported. Approximately 70 per cent of the German coke came from the Westphalia field; the remainder came from the Aix-la-Chapelle field. No large shipments of coke have been made from the Sarre field. The remaining 10 per cent of the coke imported into Belgium in 1913 came from France and Holland. Belgium has always imported a small amount of coke from France, and in 1913 this amounted to 
50,000 tons. After 1910 coke from Holland came into Belgium in amounts about equal to the French coke.

The following table and figure 11 show the production, foreign sources, and consumption of coke for the 10 years prior to the war:

Coke produced, imported, and consumed in Belgium, 1904-1913, in tons.

\begin{tabular}{|c|c|c|c|c|c|c|}
\hline \multirow{2}{*}{ Year. } & \multirow{2}{*}{$\begin{array}{l}\text { Produced } \\
\text { in } \\
\text { Belgium. }\end{array}$} & \multicolumn{4}{|c|}{ Imported. } & \multirow{2}{*}{ Consumed. } \\
\hline & & Germany. & France. & $\mid$\begin{tabular}{c|} 
Other \\
countries.
\end{tabular} & Total.a & \\
\hline 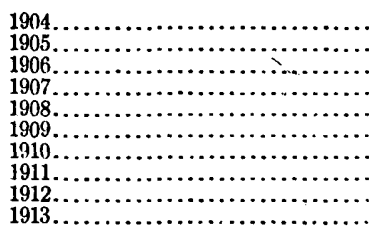 & $\begin{array}{l}2,496,340 \\
2,526,690 \\
2,712,760 \\
2,771,920 \\
2,632,890 \\
2,972,920 \\
3,110,820 \\
3,160,950 \\
3,186,780 \\
3,523,000\end{array}$ & $\begin{array}{r}292,725 \\
285,366 \\
278,455 \\
320,852 \\
251,625 \\
270,793 \\
575,150 \\
602,874 \\
850,803 \\
1,026,000\end{array}$ & $\begin{array}{l}45,000 \\
70,000 \\
73,000 \\
35,000 \\
30,090 \\
27,000 \\
22,000 \\
35,000 \\
52,000 \\
50,000\end{array}$ & $\begin{array}{r}402 \\
820 \\
861 \\
6,846 \\
5,412 \\
18,260 \\
11,977 \\
53,963 \\
52,590 \\
52,095\end{array}$ & $\begin{array}{r}388,127 \\
356,186 \\
352,316 \\
362,698 \\
287,037 \\
316,053 \\
498,128 \\
691,837 \\
955,393 \\
1,128,095\end{array}$ & $\begin{array}{l}1,954,584 \\
1,905,731 \\
2,208,601 \\
2,271,175 \\
2,002,654 \\
2,274,009 \\
2,565,286 \\
2,825,866 \\
3,126,639 \\
3,537,408\end{array}$ \\
\hline
\end{tabular}

a Increases in 1911, 1912, and 1913 due to increased imports from Holland.

In 1913 Belgian coke producers exported 1,113,687 tons, or slightly more than the average for the years from 1909 to 1913, inclusive. For the 10 years prior to the war approximately 40 per cent of the Belgian coke exported was shipped to France, 20 per cent to Germany, 20 per cent to Luxemburg, and the remaining 20 per cent to several countries in small amounts.

Statistics of Belgian coke trade, 1904-1913, in tons.

\begin{tabular}{|c|c|c|c|c|c|}
\hline Year. & Production. & Imports. & Exports. & $\begin{array}{l}\text { Excess of } \\
\text { exports. }\end{array}$ & $\begin{array}{l}\text { Consump- } \\
\text { tion. }\end{array}$ \\
\hline 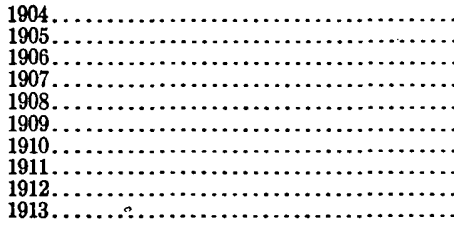 & $\begin{array}{l}2,496,340 \\
2,526,690 \\
2,712,760 \\
2,771,920 \\
2,632,890 \\
2,972,920 \\
3,110,820 \\
3,160,950 \\
3,186,780 \\
3,523,000\end{array}$ & $\begin{array}{r}338,127 \\
356,186 \\
352,316 \\
-362,698 \\
287,037 \\
316,053 \\
498,128 \\
691,837 \\
955,393 \\
1,128,095\end{array}$ & $\begin{array}{r}879,883 \\
977,095 \\
856,475 \\
863,440 \\
927,253 \\
1,014,964 . \\
1,043,662 \\
1,026,921 \\
1,015,534 \\
1,113,687\end{array}$ & $\begin{array}{r}541,756 \\
620,909 \\
504,159 \\
500,742 \\
630,216 \\
698,911 \\
545,534 \\
335,084 \\
60,141 \\
a 14,408\end{array}$ & $\begin{array}{l}1,954,584 \\
1,905,731 \\
2,208,601 \\
2,271,175 \\
2,002,654 \\
2,274,009 \\
2,565,286 \\
2,825,866 \\
3,126,639 \\
3,537,408\end{array}$ \\
\hline
\end{tabular}

$a$ Excess of imports over exports.

CONSUMPTION OF RAW MATERIALS.

The consumption of iron ore, coal, and coke has increased in direct proportion to the expansion. of the Belgian iron and steel industry during the pre-war decade.

\section{IRON ORE.}

The consumption of iron ore more than doubled during this decade, reaching $6,860,130$ tons, in 1913 . In addition 375,840 tons of scrap, slag, and residue of pyrite roasting (blue billy) was smelted, representing approximately 5 per cent of the total requirements. There was a gradual yearly increase in the quantity of this material used, amounting to about 100,000 tons from 1904 to 1913. 
The iron and steel manufacturers imported more than 90 per cent of the iron ore smelted. Ore in the future must come principally from the deposits in the Briey-Longwy and Nancy basins of French Lorraine and in small quantities from the adjacent deposits in Lorraine Annexée and Luxemburg. The imports of iron ore from Luxemburg remained at about $1,500,000$ tons a year for the 10 years prior to the war. This quantity, however, must necessarily decrease in the future, as at the time the large concessions for iron mining were made in Luxemburg the exportation of iron ore from them was prohibited: A small quantity of ore was imported from the Bilboa district in Spain and used in the manufacture of Bessemer steel. This ore represented less than 1 per cent of the total requirements.

Iron ore, etc., consumed in Belgian biast furnaces, 1904-191s.

\begin{tabular}{|c|c|c|c|c|c|}
\hline \multirow{2}{*}{ Year. } & \multirow{2}{*}{$\begin{array}{c}\text { Ore } \\
\text { produced } \\
\text { in } \\
\text { Belgium } \\
\text { (tons). }\end{array}$} & \multirow{2}{*}{$\begin{array}{c}\text { Scrap, } \\
\text { slag, and } \\
\text { residue } \\
\text { from } \\
\text { pyrite } \\
\text { roasting } \\
\text { (tons). }\end{array}$} & \multicolumn{2}{|c|}{ Ore imported. } & \multirow[b]{2}{*}{$\begin{array}{l}\text { Total con- } \\
\text { sumption } \\
\text { (tons). }\end{array}$} \\
\hline & & & $\begin{array}{l}\text { Quantity } \\
\text { (tons). }\end{array}$ & $\begin{array}{c}\text { Percent- } \\
\text { age of } \\
\text { total con- } \\
\text { sumption. }\end{array}$ & \\
\hline 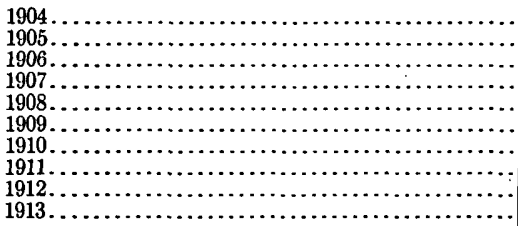 & $\begin{array}{r}137,950 \\
133,150 \\
127,550 \\
129,170 \\
146,430 \\
126,810 \\
84,220 \\
54,470 \\
89,860 \\
84,900\end{array}$ & $\begin{array}{l}268,135 \\
290,7204 \\
291,460 \\
311,710 \\
244,760 \\
263,910 \\
304,310 \\
278,580 \\
379,270 \\
375,840\end{array}$ & $\begin{array}{l}3,134,855 \\
3,190,150 \\
3,548,180 \\
3,699,750 \\
3,408,650 \\
4,401,540 \\
4,978,610 \\
5,388,080 \\
6,221,990 \\
6,775,230\end{array}$ & $\begin{array}{l}88 \\
88 \\
89 \\
89 \\
90 \\
92 \\
93 \\
94 \\
93 \\
94\end{array}$ & $\begin{array}{l}3,540,990 \\
3,614,020 \\
3,967,190 \\
4,140,630 \\
3,789,840 \\
4,792,260 \\
5,367,140 \\
5,721,130 \\
6,691,120 \\
7,235,970\end{array}$ \\
\hline
\end{tabular}

\section{COAL.}

The annual consumption of coal in the iron and steel industry remained approximately constant at 1,200,000 tons during the period from 1904 to 1913. The amount of coal imported, however, increased from 95,000 tons, or 8 per cent of the requirements, in 1904, to 237,040 tons, or 20 per cent, in 1913. The increase in the importation of coal was marked after 1910 and was due primarily to the gradual inroads of the Westphalian producers into the Belgian markets.

Coal consumed in Belgian iron and steel industry, 1904-191s.

\begin{tabular}{|c|c|c|c|c|}
\hline \multirow{2}{*}{ Year. } & \multirow[b]{2}{*}{$\begin{array}{l}\text { Domestic } \\
\text { (tons). }\end{array}$} & \multicolumn{2}{|c|}{ Imported. } & \multirow[b]{2}{*}{$\begin{array}{l}\text { Total } \\
\text { (tons). }\end{array}$} \\
\hline & & $\begin{array}{l}\text { Quantity } \\
\text { (tons). }\end{array}$ & $\begin{array}{l}\text { Percent- } \\
\text { age of } \\
\text { total con- } \\
\text { sumption. }\end{array}$ & \\
\hline 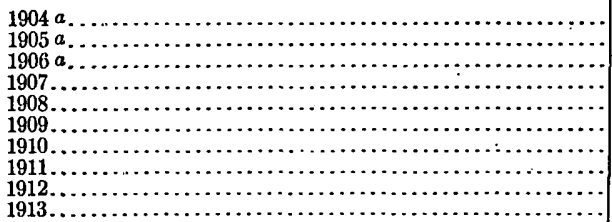 & $\begin{array}{r}1,097,910 \\
1,094,800 \\
1,215,180 \\
1,215,120 \\
892,300 \\
1,001,220 \\
1,029,750 \\
1,008,120 \\
1,060,240 \\
960,950\end{array}$ & $\begin{array}{r}95,000 \\
110,000 \\
131,670 \\
136,550 \\
103,720 \\
108,389 \\
136,060 \\
195,070 \\
243,920 \\
237,040\end{array}$ & $\begin{array}{r}8 \\
9 \\
10 \\
10 \\
10 \\
10 \\
12 \\
16 \\
19 \\
20\end{array}$ & $\begin{array}{r}1,192,910 \\
1,204,800 \\
1,346,850 \\
1,351,670 \\
996,020 \\
1,109,609 \\
1,165,810 \\
1,203,190 \\
1,304,160 \\
1,197,990\end{array}$ \\
\hline
\end{tabular}




\section{COKE.}

The production of coke in Belgium for the use of the iron and steel industry nearly doubled in the pre-war decade, increasing from $1,308,260$ tons in 1904 to $2,115,610$ tons in 1913. This increase was not sufficient to fill the requirements, and the imports of coke increased from 84,820 tons, or 5 per cent of the total requirements, in 1909 to 639,270 tons, or 23 per cent, in 1913. About 90 per cent of this imported coke came from the Westphalia and Aix-la-Chapelle districts of Germany.

It is apparent that the future requirements of coal and coke in the iron and steel industry will be only in part filled by the existing developed coalmines and coke plants in Belgium. In the main the supply of the future must depend upon the exploitation of the Campine Basin and for any deficit must resort to the Westphalia district of Germany. It is probable that this district will always be a factor in the competition for Belgian coal and coke markets, owing to the low production cost, the high quality of the product, and the favorable rail location.

Coke consumed in Belgian iron and steel industry, 1904-1913.

Year.
$\ldots$

$a$ Estimated.

Coal and coke used in Belgium in 1913 by consumers, in tons.

\begin{tabular}{|c|c|c|c|c|}
\hline \multirow{2}{*}{ Consumers. } & \multicolumn{2}{|c|}{ Coal. } & \multicolumn{2}{|c|}{ Coke. } \\
\hline & Domestic. & Foreign. & Domestic. & Foreign. \\
\hline \multirow[t]{2}{*}{$\begin{array}{l}\text { Blast furnaces } \\
\text { Steel plants } \ldots \ldots \ldots \ldots \ldots \\
\text { Manufacturers of finished products } \ldots \ldots \ldots \ldots\end{array}$} & $\begin{array}{r}20,780 \\
573,840 \\
336,330\end{array}$ & $\begin{array}{r}3,660 \\
119,410 \\
113,970\end{array}$ & $\begin{array}{r}2,034,750 \\
80,860 \\
.\end{array}$ & $\begin{array}{r}627,930 \\
11,340 \\
\ldots\end{array}$ \\
\hline & 930,950 & 237,040 & $2,115,610$ & 639,270 \\
\hline
\end{tabular}

\section{PRODUCTION OF IRON AND STEEL.}

The Belgian iron and steel industry practically doubled its output during the pre-war decade, 1904 to 1913 . The number of companies and corporations smelting iron ore increased by 1 during this period. The number of blast furnaces, however, increased from 43 in 1904, of which 34 were in blast; to 57 in 1913, of which 54 were in blast. 
PIG IRON.

This increase in the number of blast furnaces, together with improvements in practice, nearly doubled the production of pig iron during the 10-year period, the 1913 output being 2,484,690 tons'. The production of foundry iron remained constant and in 1913 was 93,830 tons. There was a heavy falling off in the production of forge iron, from 224,410 tons in 1904 to 66,370 tons in 1913. An even greater shrinkage took place in the production of pig for the manufacture of acid Bessemer steel, which was reduced from 217,390 tons in 1904 to 32,260 tons in 1913. The production of pig for the manufacture of steel by the Thomas process more than trebled between 1904 and 1913, increasing from 742,040 to $2,291,390$ tons. The production of special grades of pig iron was small up to 1912. During this year the production was abnormally large, but in 1913 it was somewhat reduced.

The following table and figure 12 give the tonnage and average value of the different grades of pig iron produced in Belgian blast furnaces for the years 1904 to 1913, inclusive:

Statistics of pig-iron production in Belgium, 1904-1913.

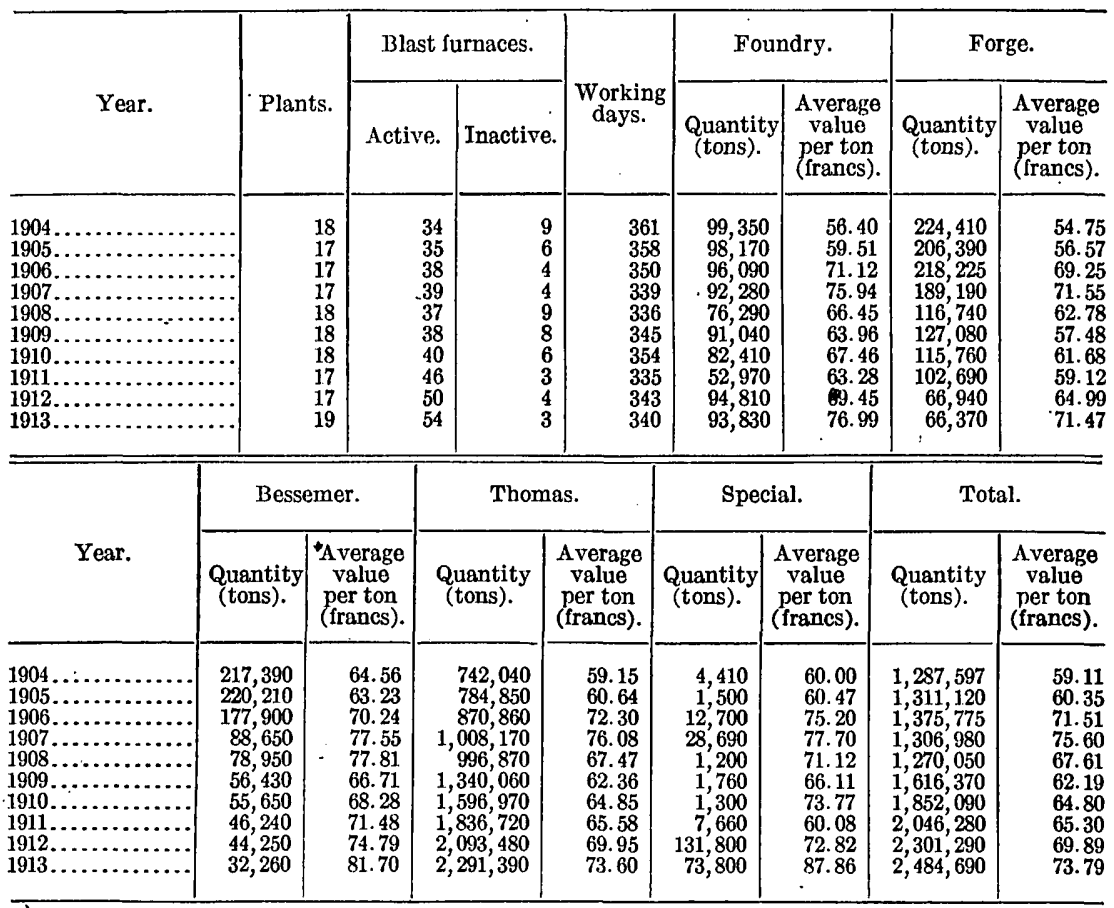

Belgium imported pig iron each year in quantities ranging from 10 to 25 per cent of the domestic production. The greater part of this iron came from Germany and Luxemburg. The quantity of pig iron exported from Belgium was negligible. 


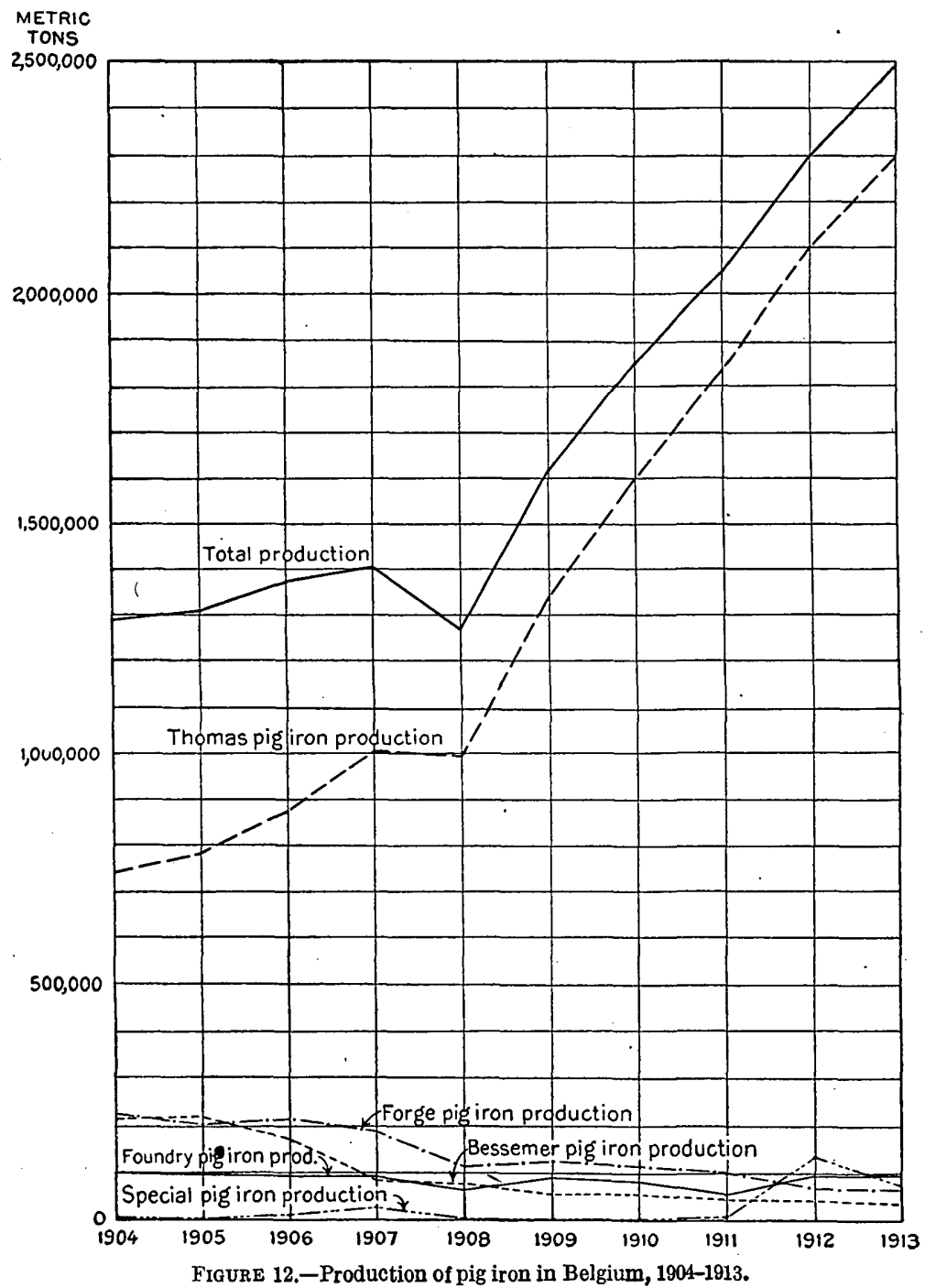

Figure 12.-Production of pig iron in Belgium, 1904-1913.

Pig iron imported, exported, and consumed in Belgium, 1912-13, in tons.

\begin{tabular}{|c|c|c|}
\hline & 1912 & 1913 \\
\hline 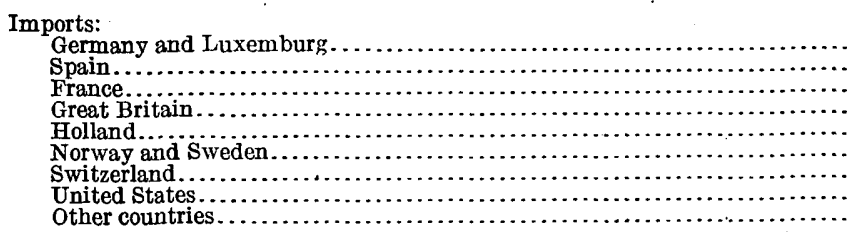 & $\begin{array}{r}531,810 \\
86 \\
130,789 \\
115,307 \\
63 \\
882 \\
90 \\
1,221 \\
117\end{array}$ & $\begin{array}{r}362,474 \\
66 \\
80,541 \\
129,543 \\
661 \\
964 \\
165 \\
3,861 \\
135\end{array}$ \\
\hline Domestic production. ......................... & $\begin{array}{r}780,365 \\
2,301,290\end{array}$ & $\begin{array}{r}578,410 \\
2,484,690\end{array}$ \\
\hline Exports. & $\begin{array}{r}3,081,655 \\
11,637\end{array}$ & $\begin{array}{r}3,063,100 \\
16,750\end{array}$ \\
\hline Consumption.............. & $3,070,018$ & $2,046,350$ \\
\hline
\end{tabular}


STEEL.

The number of companies producing crude and manufactured steel products increased from 24 in 1904 to 30 in 1913. During 1913 two of these plants did not operate. The expansion during this period is best shown by the following table:

Metallurgic and mechanical equipment of Belgian steel companies, 1904 and 1913.

\begin{tabular}{|c|c|c|}
\hline V & 1904 & 1913 \\
\hline 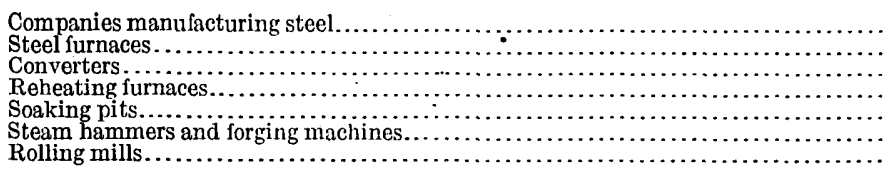 & $\begin{array}{l}24 \\
24 \\
48 \\
90 \\
82 \\
28 \\
54\end{array}$ & $\begin{array}{r}30 \\
26 \\
84 \\
135 \\
158 \\
35 \\
79\end{array}$ \\
\hline
\end{tabular}

The amount of steel produced during the pre-war decade more than doubled, increasing from $1,090,770$ tons to $2,466,630$ tons in 1913. The quantity of domestic pig iron used for the production of steel in 1913 was 2,432,900 tons. The quantity of foreign pig iron converted into steel increased from 165,600 tons, or 15 per cent of the domestic iron, in 1904 to 500,550 tons, or 29 per cent, in 1910 . From 1910 through 1912 the annual imports of pig for steel remained above 500,000 tons, but in 1913 they dropped to 396,250 tons, or 15.5 per cent of the domestic iron.

Practically all the steel produced during the period 1904 to 1913 was manufactured by the open-hearth process. In 1913 the output of steel of this grade was 89 per cent of the year's production.

Crude steel produced in Belgium, 1904-1913.

\begin{tabular}{|c|c|c|c|c|c|c|c|c|c|}
\hline \multirow{3}{*}{ Year. } & \multicolumn{2}{|c|}{$\begin{array}{l}\text { Pig iron consumed } \\
\text { (tons). }\end{array}$} & \multicolumn{7}{|c|}{ Steel produced. } \\
\hline & \multirow[b]{2}{*}{ Domestic. } & \multirow[b]{2}{*}{ Foreign. } & \multicolumn{2}{|c|}{ Direct castings. } & \multicolumn{2}{|c|}{ Open hearth. } & \multicolumn{2}{|c|}{ Bessemer. } & \multirow[b]{2}{*}{$\begin{array}{c}\text { Total } \\
\text { (tons) }\end{array}$} \\
\hline & & & $\begin{array}{l}\text { Quan- } \\
\text { tity. } \\
\text { (tons). }\end{array}$ & $\begin{array}{c}\text { Aver- } \\
\text { age } \\
\text { value } \\
\text { per ton } \\
\text { (francs). }\end{array}$ & $\begin{array}{l}\text { Quantity } \\
\text { (tons). }\end{array}$ & $\begin{array}{c}\text { Aver- } \\
\text { age } \\
\text { value } \\
\text { per ton } \\
\text { (francs). }\end{array}$ & $\begin{array}{c}\text { Quantity } \\
\text { (tons). }\end{array}$ & $\begin{array}{c}\text { Aver- } \\
\text { age } \\
\text { value } \\
\text { per ton } \\
\text { (francs). }\end{array}$ & \\
\hline $\begin{array}{l}1904 \ldots . \\
1905 \ldots . \\
1906 \ldots . \\
1907 \ldots . \\
1908 \ldots \\
1909 \ldots \\
1910 \ldots \\
1911 \ldots . \\
1912 \ldots . \\
1913 \ldots .\end{array}$ & $\begin{array}{l}1,083,600 \\
1,110,940 \\
1,220,835 \\
1,303,580 \\
1,171,620 \\
1,535,620 \\
1,751,920 \\
2,015,425 \\
2,875,860 \\
2,432,900\end{array}$ & $\begin{array}{l}165,600 \\
299,730 \\
438,660 \\
462,760 \\
283,090 \\
354,200 \\
500,550 \\
518,660 \\
559,100 \\
396,250\end{array}$ & $\begin{array}{l}24,900 \\
26,680 \\
45,720 \\
54,900 \\
51,620 \\
52,040 \\
52,660 \\
64,460 \\
72,620 \\
61,850\end{array}$ & $\begin{array}{l}276.05 \\
278.81 \\
322.20 \\
364.18 \\
344.58 \\
310.80 \\
302.50 \\
318.96 \\
324.73 \\
326.60\end{array}$ & $\begin{array}{r}952,090 \\
1,095,880 \\
1,277,010 \\
1,289,750 \\
1,070,840 \\
1,470,400 \\
1,755,500 \\
1,971,760 \\
2,252,380 \\
2,192,180\end{array}$ & $\begin{array}{r}80.70 \\
81.95 \\
91.51 \\
101.54 \\
88.21 \\
80.61 \\
84.68 \\
84.38 \\
88.72 \\
94.12\end{array}$ & $\begin{array}{l}113,780 \\
104,550 \\
118,130 \\
176,960 \\
127,160 \\
109,950 \\
136,660 \\
156,410 \\
190,040 \\
212,600\end{array}$ & \begin{tabular}{|r|}
89.88 \\
92.90 \\
103.65 \\
11.13 \\
99.91 \\
94.64 \\
94.98 \\
94.38 \\
99.53 \\
102.22
\end{tabular} & $\begin{array}{l}1,090,770 \\
1,227,110 \\
1,440,860 \\
1,521,610 \\
1,249,620 \\
1,632,390 \\
1,944,820 \\
2,192,630 \\
2,515,040 \\
2,466,630\end{array}$ \\
\hline
\end{tabular}

A large proportion of the steel produced was worked directly into forged ingots, blooms, and billets. 
Semifinished steel produced in Belgium, 1904-1913.

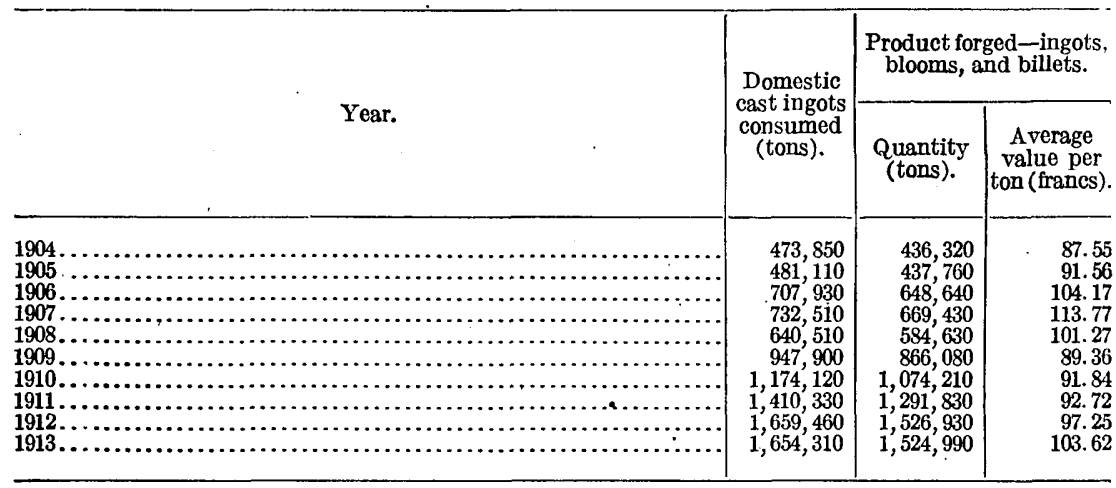

The consumption of ingots, blooms, and billets by steel producers and manufacturers of finished steel products more than doubled during the pre-war decade and in 1913 reached 2,046,820 tons. The imports of foreign ingots, billets, and blooms decreased during this period and in 1913 amounted to 67,500 tons. The steel producers imported very small amounts of semifinished steel, and in 1913 all the foreign steel used was imported by the manufacturers of finished steel products not operating large metallurgic plants.

The steel plants made 62 per cent of the finished steel products in 1904 and gradually increased their relative production to 75 per cent in 1913. The total quantity of finished steel products increased from $1,023,560$ to $1,857,860$ tons.

Finished steel products manufactured in Belgium, 1913.

\begin{tabular}{|c|c|c|}
\hline & $\begin{array}{l}\text { Quantity } \\
\text { (tons). }\end{array}$ & $\begin{array}{l}\text { Average } \\
\text { value } \\
\text { per ton } \\
\text { (francs). }\end{array}$ \\
\hline 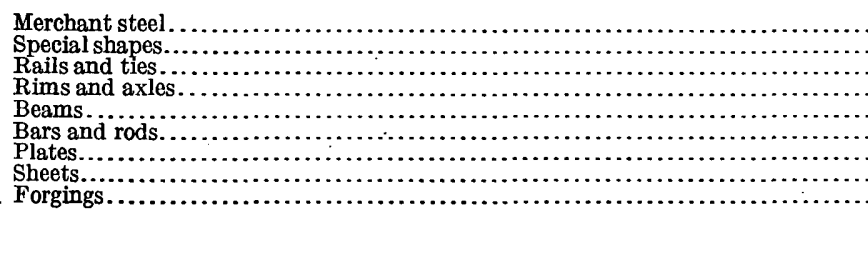 & $\begin{array}{r}614,130 \\
187,420 \\
341,870 \\
34,140 \\
175,210 \\
142,220 \\
236,060 \\
118,590 \\
8,220 \\
1,857,860\end{array}$ & $\begin{array}{l}132.62 \\
140.98 \\
131.74 \\
210.61 \\
126.32 \\
132.22 \\
154.37 \\
193.68 \\
218.74 \\
141.20\end{array}$ \\
\hline
\end{tabular}

The number of companies buying pig iron and crude or semifinished steel in the market for the manufacture of finished steel and iron products decreased from 51 in 1904 to 38 in 1913 . The tonnage of finished products produced by these companies remained practically unchanged during the 10-year period. 
Finished steel products manufactured in Belgium, 1904-1913.

\begin{tabular}{|c|c|c|c|c|c|c|c|}
\hline \multirow{3}{*}{ Year. } & \multicolumn{2}{|c|}{$\begin{array}{l}\text { Ingots, blooms, and } \\
\text { billets consumed (tons). }\end{array}$} & \multicolumn{5}{|c|}{ Finished steel products. } \\
\hline & \multirow{2}{*}{ Belgian. } & \multirow{2}{*}{ Foreign. } & \multicolumn{2}{|c|}{$\begin{array}{l}\text { From steel-producing } \\
\text { plants. }\end{array}$} & \multicolumn{2}{|c|}{$\begin{array}{l}\text { From plants manufac- } \\
\text { turing only finished } \\
\text { products. }\end{array}$} & \multirow{2}{*}{$\begin{array}{c}\text { Total } \\
\text { (tons). }\end{array}$} \\
\hline & & & $\begin{array}{l}\text {-Quantity } \\
\text { (tons). }\end{array}$ & $\begin{array}{c}\text { Average } \\
\text { value per } \\
\text { ton (franes) }\end{array}$ & $\begin{array}{l}\text { Quantity } \\
\text { (tons). }\end{array}$ & $\begin{array}{c}\text { Average } \\
\text { value per } \\
\text { ton (francs). }\end{array}$ & \\
\hline 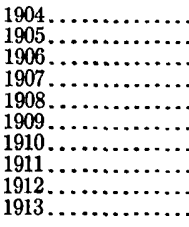 & $\begin{array}{l}1,055,870 \\
1,148,1.50 \\
1,281,515 \\
1,202,480 \\
1,079,150 \\
1,388,550 \\
1,606,580 \\
1,828,200 \\
2,113,090 \\
2,046,820\end{array}$ & $\begin{array}{r}135,850 \\
136,610 \\
92,825 \\
222,500 \\
79,960 \\
84,265 \\
153,580 \\
77,150 \\
64,025 \\
67,500\end{array}$ & $\begin{array}{r}630,290 \\
768,470 \\
831,570 \\
913,310 \\
765,870 \\
947,660 \\
1,155,740 \\
1,236,620 \\
1,399,270 \\
1,409,460\end{array}$ & $\begin{array}{r}116.87 \\
119.09 \\
137.15 \\
151.40 \\
133.80 \\
117.98 \\
118.90 \\
120.71 \\
128.52 \\
134.50\end{array}$ & $\begin{array}{l}393,270 \\
322,930 \\
333,175 \\
303,380 \\
234,530 \\
316,990 \\
378,810 \\
418,340 \\
504,000 \\
448,400\end{array}$ & $\begin{array}{l}134.17 \\
142.38 \\
165.07 \\
180.30 \\
156.77 \\
144.06 \\
144.72 \\
146.02 \\
154.71 \\
162.31\end{array}$ & $\begin{array}{r}1,023,560 \\
1,091,400 \\
1,164,745 \\
1,216,690 \\
989,400 \\
1,264,650 \\
1,534,550 \\
1,654,960 \\
1,903,270 \\
1,856,860\end{array}$ \\
\hline
\end{tabular}

Equipment of Belgian companies manufacturing finished iron and steel products, 1904 and 1913 .

\begin{tabular}{|c|c|c|}
\hline . & 1904 & 1913 \\
\hline 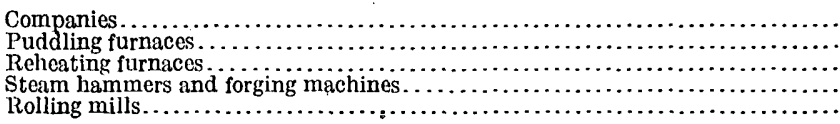 & $\begin{array}{r}51 \\
322 \\
413 \\
89 \\
174\end{array}$ & $\begin{array}{r}38 \\
110 \\
317 \\
45 \\
137\end{array}$ \\
\hline
\end{tabular}

\section{PUDDLED AND FORGE IRON.}

The annual production of puddled and forge iron decreased during the 10-year pre-war period: The amount of material consumed in 1913 was 113,690 tons of domestic and 40,860 tons of imported pig iron. The puddling iron produced amounted to 131,220 tons and the forge iron to 13,980 tons.

Puddled and forge iron produced in Belgium, 1904-1913.

\begin{tabular}{|c|c|c|c|c|c|c|c|}
\hline \multirow[b]{2}{*}{ Year. } & \multicolumn{2}{|c|}{$\begin{array}{l}\text { Pig iron consumed } \\
\text { (tons). }\end{array}$} & \multicolumn{2}{|c|}{$\begin{array}{l}\text { Puddled iron pro- } \\
\text { duced. }\end{array}$} & \multirow{2}{*}{$\begin{array}{l}\text { Pig scrap } \\
\text { consumed } \\
\text { (tons). }\end{array}$} & \multicolumn{2}{|c|}{ Forge iron produced. } \\
\hline & Domestic. & Troreign. & $\begin{array}{l}\text { Quantity } \\
\text { (tons). }\end{array}$ & $\begin{array}{l}\text { Average } \\
\text { value } \\
\text { per ton } \\
\text { (irancs). }\end{array}$ & & $\begin{array}{l}\text { Quantity } \\
\text { (tons). }\end{array}$ & $\begin{array}{c}\text { Average } \\
\text { value } \\
\text { per ton } \\
\text { (francs). }\end{array}$ \\
\hline 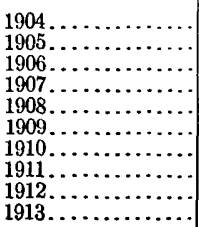 & $\begin{array}{l}229,280 \\
223,180 \\
223,780 \\
203,270 \\
165,430 \\
170,210 \\
148,710 \\
103,660 \\
111,960 \\
113,690\end{array}$ & $\begin{array}{l}91,310 \\
94,370 \\
64,280 \\
67,710 \\
40,800 \\
25,845 \\
30,780 \\
48,770 \\
63,550 \\
40,860\end{array}$ & $\begin{array}{l}290,790 \\
274,560 \\
250,130 \\
235,130 \\
277,740 \\
168,010 \\
152,650 \\
131,380 \\
149,280 \\
131,220\end{array}$ & $\begin{array}{r}91.85 \\
93.24 \\
111.51 \\
117.27 \\
104.79 \\
94.78 \\
100.20 \\
96.04 \\
104.97 \\
114.64\end{array}$ & $\begin{array}{l}24,400 \\
23,119 \\
24,120 \\
24,695 \\
22,580 \\
20,345 \\
18,715 \\
19,930 \\
19,850 \\
16,981\end{array}$ & $\begin{array}{l}19,970 \\
18,957 \\
19,430 \\
20,050 \\
18,080 \\
17,155 \\
15,310 \\
17,010 \\
16,810 \\
13,980\end{array}$ & $\begin{array}{l}112.30 \\
115.14 \\
126.19 \\
129.64 \\
116.05 \\
112.00 \\
109.60 \\
116.64 \\
128.62 \\
122.89\end{array}$ \\
\hline
\end{tabular}




\section{FINISHED IRON SHAPES.}

The production of finished iron shapes showed a decline during the pre-war. decade.

Finished iron shapes produced in Belgium, 1904-1913.

\begin{tabular}{|c|c|c|c|}
\hline \multirow[b]{2}{*}{ Year. } & \multirow{2}{*}{$\begin{array}{c}\text { Pig iron } \\
\text { con- } \\
\text { sumed } \\
\text { (tons). }\end{array}$} & \multicolumn{2}{|c|}{$\begin{array}{l}\text { Finished shapes } \\
\text { produced. }\end{array}$} \\
\hline & & $\begin{array}{c}\text { Quantity } \\
\text { (tons). }\end{array}$ & $\begin{array}{l}\text { Average } \\
\text { value } \\
\text { per ton } \\
\text { (francs). }\end{array}$ \\
\hline 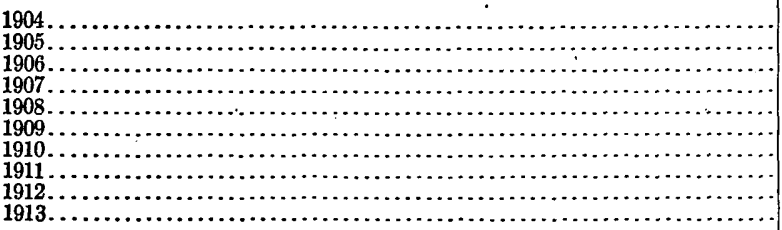 & $\begin{array}{l}435,670 \\
463,360 \\
434,180 \\
451,640 \\
386,630 \\
384,295 \\
364,970 \\
364,720 \\
432,020 \\
393,420\end{array}$ & $\begin{array}{l}355,190 \\
377,620 \\
358,250 \\
358,500 \\
306,650 \\
304,910 \\
299,500 \\
290,270 \\
334,750 \\
304,350\end{array}$ & $\begin{array}{l}126.76 \\
127.38 \\
148.80 \\
160.86 \\
135.62 \\
127.41 \\
131.84 \\
129.60 \\
137.50 \\
143.32\end{array}$ \\
\hline
\end{tabular}

Finished iron shapes produced in Belgium, 1918.

\begin{tabular}{|c|c|c|}
\hline & $\begin{array}{l}\text { Quantity } \\
\text { (tons). }\end{array}$ & $\begin{array}{c}\text { Average } \\
\text { value } \\
\text { per ton } \\
\text { (francs). }\end{array}$ \\
\hline \multirow[t]{2}{*}{ 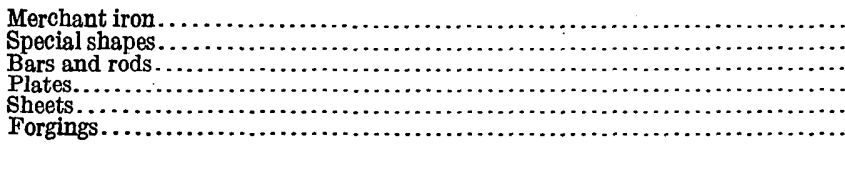 } & $\begin{array}{r}241,420 \\
26,520 \\
11,270 \\
5,140 \\
19,980 \\
20\end{array}$ & $\begin{array}{l}137.65 \\
159.88 \\
148.37 \\
150.45 \\
184.43 \\
340.00\end{array}$ \\
\hline & 304,350 & 143.32 \\
\hline
\end{tabular}

\section{WORKMIEN.}

The number of workmen employed in the production of pig iron, steel, and finished products during 1913 was as follows:

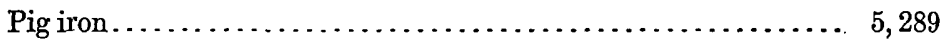

Steel and steel products........................... 19, 132

Finished iron and steel products....................... 10, 879 
IMPORTS AND EXPORTS.

\section{Belgium has always exported the larger percentage of her iron and} steel products.

Belgian imports and exports of iron and steel products, 191s, in tons.

\begin{tabular}{|c|c|c|}
\hline & Imports. & Exports. \\
\hline 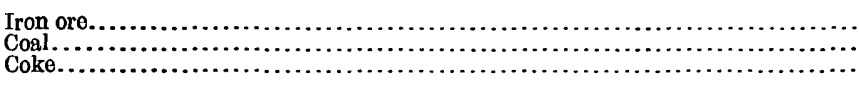 & $\begin{array}{l}6,775,230 \\
8,856,153 \\
1,128,095\end{array}$ & $\begin{array}{r}66,550 \\
5,112,499 \\
1,113,687\end{array}$ \\
\hline 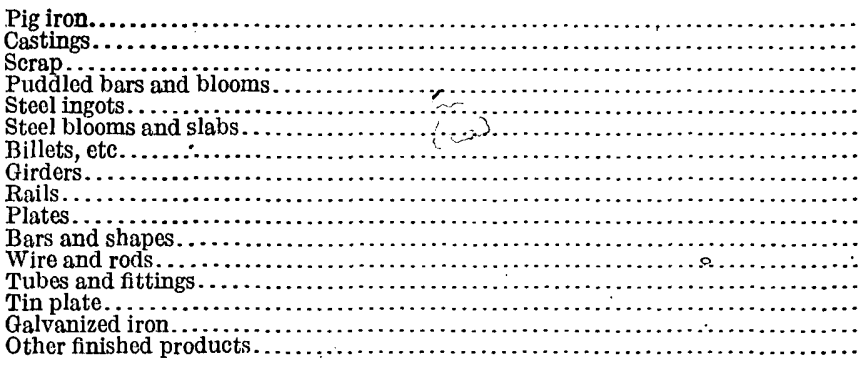 & $\begin{array}{r}578,408 \\
10,170 \\
119,593 \\
213 \\
6,045 \\
54,388 \\
21,117 \\
1,680 \\
8,566 \\
24,196 \\
48,368 \\
63,510 \\
15,518 \\
12,414 \\
1,012 \\
20,404\end{array}$ & $\begin{array}{r}16,760 \\
26,737 \\
152,782 \\
4,905 \\
279 \\
43,291 \\
110,323 \\
95,338 \\
164,584 \\
196,223 \\
649,412 \\
54,768 \\
2,881 \\
2,678 \\
5,554 \\
200,306\end{array}$ \\
\hline Total iron and steel products....... & 985,602 & $1,726,821$ \\
\hline
\end{tabular}

Belgian iron and steel products exported in 1913, by countries, in tons.

\begin{tabular}{|c|c|c|c|c|c|c|c|}
\hline Country. & $\begin{array}{c}\text { Pig } \\
\text { iron. }\end{array}$ & $\begin{array}{l}\text { Fin- } \\
\text { ished } \\
\text { iron } \\
\text { prod- } \\
\text { ucts. }\end{array}$ & $\begin{array}{c}\text { Tron and } \\
\text { steel } \\
\text { scrap. }\end{array}$ & $\begin{array}{l}\text { Cast- } \\
\text { steel } \\
\text { ingots, } \\
\text { blooms, } \\
\text { and } \\
\text { billets. }\end{array}$ & $\begin{array}{l}\text { Iron and } \\
\text { steel } \\
\text { shapes, } \\
\text { beams, } \\
\text { rails, } \\
\text { plate, otc. }\end{array}$ & $\begin{array}{l}\text { Fin- } \\
\text { ished } \\
\text { iron } \\
\text { and } \\
\text { steel } \\
\text { prod- } \\
\text { ucts, } \\
\text { rails, } \\
\text { pipe, } \\
\text { otc. }\end{array}$ & $\begin{array}{c}\text { Gal- } \\
\text { van- } \\
\text { ized, } \\
\text { cop- } \\
\text { pered, } \\
\text { and } \\
\text { leaded } \\
\text { iron } \\
\text { sheets. }\end{array}$ \\
\hline 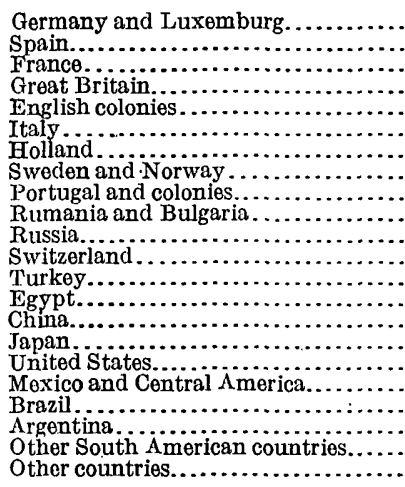 & $\begin{array}{r}353 \\
200 \\
13,898 \\
6 \\
\ldots \ldots \ldots \\
\ldots \ldots \\
714 \\
\ldots \ldots\end{array}$ & $\begin{array}{r}2,338 \\
270 \\
3,581 \\
707 \\
31 \\
193 \\
4,025 \\
100 \\
115 \\
586 \\
31 \\
165 \\
1,533 \\
467 \\
132 \\
46 \\
11 \\
24 \\
4,043 \\
5,752 \\
287 \\
2,300\end{array}$ & 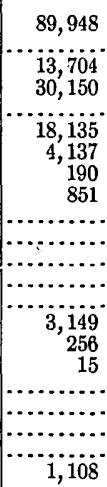 & $\begin{array}{r}79 \\
0.190 \\
137,588 \\
8,965 \\
705 \\
125 \\
\ldots \ldots \\
\\
\hdashline\end{array}$ & $\begin{array}{r}3,614 \\
24,221 \\
23,915 \\
261,266 \\
215,331 \\
16,962 \\
83,228 \\
29,766 \\
31,565 \\
5,353 \\
8,214 \\
1,754 \\
41,221 \\
32,897 \\
41,766 \\
53,292 \\
4,799 \\
3,294 \\
58,752 \\
102,124 \\
25,831 \\
91,160\end{array}$ & $\begin{array}{r}5,056 \\
4,825 \\
14,158 \\
33,802 \\
18,546 \\
2,141 \\
18,311 \\
3,424 \\
4,871 \\
2,911 \\
1,030 \\
387 \\
10,750 \\
5,860 \\
4,989 \\
4,208 \\
344 \\
3,571 \\
33,477 \\
11,004 \\
5,121 \\
18,419\end{array}$ & 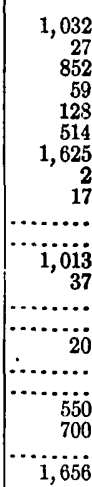 \\
\hline & 16,760 & 26,737 & 157,687 & 153,893 & $1,160,325$ & 203,187 & 8,232 \\
\hline
\end{tabular}


METALLURGIC PLANTS.

The following paragraphs give brief descriptions of most of the blast furnaces and steel-producing plants in Belgium. (See map, Pl. I, in pocket.) The information concerning the damages to these plants during the war is not first hand. The length of time necessary to put the blast furnaces and steel plants in repair can at best be but a rough estimate, as it depends to a large extent on the delivery of new material, machinery, etc.

Société des aciéries d'Angleur, Tilleur-lez-Liége. Capital, 10,000,000 francs. This company operated four blast furnaces, a steel furnace, and a rolling mill. It had a daily production of about 400 tons. It owns interests in iron mines in the vicinity of Audun and operated a battery of coke furnaces at Angleur. All the blast furnaces were damaged, but two of them can be put into working order within a comparatively short time.

Société anonyme d'Athus-Grivegnée, Grivegnée-lez-Liége. Capital, 16,000,000 francs (some Luxemburg capital). This company represents the combination of the Société des hauts fourneaux et aciéries d'Athus and the Société des Grivegnée. It owns and controls mineral lands, modern coking plants, four blast furnaces, steel converters, and rolling mills for the production of semifinished and finished products. The plant at Athus consisted of three blast furnaces of 160 tons daily capacity each, a Thomas and a Martin furnace, and a rolling mill producing semifinished products. These were sent to the finishing plant at Grivegnée. The plant at Grivegnee consisted of one blast furnace of 110 tons daily capacity, one Thomas furnace, and a finishing mill. The daily production of this company was approximately 425 tons of steel.

The company owns a dock 700 meters long on the Ourthe Canal. The mineral holdings of the company are in Belgium and Luxemburg. A part of its land at Otange is held conjointly with the Rondange company and La Providence. The company's ownership in the coke furnaces consists of a half interest in the Société anonyme des forges à coke et à gaz de Grivegnée and the Association métallurgique pour la fabrication de coke de Willebroek.

Usines Bonehill, Marchienne-au-Pont. Capital, 2,437,500 francs. This company operated two blast furnaces, each having a daily capacity of 125 tons, and one furnace for the production of refined pig, having a daily capacity of 80 tons. It also operated a rolling mill producing semifinished and finished products and made a specialty of installing rolling mills for iron and steel products. The company operated a battery of coke ovens having a daily production of 150 tons.

Usines de Châtelineau, Châtelineau. Capital, 7,000,000 francs. This company operated two blast furnaces, a steel furnace, and a rolling mill. The blast furnaces had a daily capacity of approximately 160 tons each and the steel furnace a daily production of about 290 tons. Prior to the war this company had made arrangements to install a blooming mill and an additional mill for finished products. This company owns interests in coal mines and coke companies. It was expected that the two blast furnaces damaged by the Germans would be in operation sometime before November $1,1919$.

Société John Cockerill, Seraing. Capital, 50,000 shares with no par value; 25,000,000 francs capital stock in circulation; 15,187,500 francs notes in circulation. This is one of the largest of the Belgian iron and steel companies. It was organized in 11 divisions, operating coal mines, coking plants, iron mines, blast furnaces, steel plants, foundries, forges, and rolling mills. It constructed various types of machinery, ordnance, bridges, boilers, etc., and has a shipyard at Hoboken, near Antwerp. The coal concession amounts to 307 hectares and has three shafts, only one of which is a 
hoisting shaft. The average daily production was 1,200 tons. The coking plant consisted of five batteries, totaling 138 ovens, using the Semet-Solvay process. The production of the coke furnaces was about 1,000 tons a day.

The company owns important mineral concessions at Rumelange, Luxemburg, and has interests in other concessions in French Lorraine. These mines provided about 550,000 tons of ore a year. This company also has a two-sevenths interest in the mines at Somorostre, near Bilbao, Spain, and imported annually about 150,000 tons of low-phosphorus ore, suitable for Bessemer converters. This company operated seven blast furnaces, of which four had a daily production of 100 tons and three an average production of 200 tons. The steel-making plant consisted of two Bessemer converters and three Thomas converters, which had a capacity of 15 tons each. There was also a battery of five connected Seamans-Martin furnaces, each with a capacity of 15 tons. The rolling mills, foundries, forges, and construction shops produced finished products of all kinds for industrial and military purposes. Of the seven blast furnaces five were entirely demolished. It was expected that one furnace would be in operation before July 1, 1919.

Société métallurgique d'Espérance-Longdoz, Seraing. Capital, 50,000 shares with no par value; $9,041,500$ francs obligations outstanding. This company owns and operated coal mines, coke plants, blast furnaces, a coking plant, and a rolling mill. The mines of St. Pierremont produced 1,000,000 tons of coal in 1914. The coking plant consisted of a battery of 100 ovens at Flémalle-Grande and was to have been fired in the spring of 1915. The iron-ore requirements of this company for the next 50 years are taken care of by its interests in iron-ore concessions in the Briey and Nancy basins. It also owns an interest in a manganese mine in Brazil. The company had three blast furnaces, each of 150 tons capacity, and three converters. It operated an iron foundry and a plate rolling mill in conjunction with them. The daily capacity of this plant was 450 tons.

Société des hauts fourneaux de Fontoy. Capital, 2,500,000 francs. In 1904 this company was absorbed by the Aumetz la Paix company, which was liquidated October 31, 1917. The entire proceeds were put into the Lothringen Hütten und Bergwerks Verein, a German-owned corporation operating principally in Lorraine Annexée.

Société des hauts fourneaux et mines de Halanzy, Halanzy. Capital, 2,200,000 francs (mixed Belgium and Luxemburg). This company owns important ironmining concessions in Luxemburg and Belgium. It has an interest in the Association métallurgique de Willebrook, which manufactured coke. The company operated two blast furnaces having a daily production of 155 tons each of foundry pig.

Forges de Clabecq, Clabecq (Brabant). Capital, 6,000,000 francs. This company owns a large interest in the Fours a coke a Vilvoide, which furnishes the coke necessary for its blast furnaces.. The plant consisted of two blast furnaces, a steel plant having three Thomas converters of 12 tons each, and a Martin furnace of 15 tons daily capacity. The daily production of this plant was approximately 360 tons of steel products. The two blast furnaces were destroyed by the Germans, and no time has been set for the resumption of operations.

Société minière et métallurgique de Monceau St. Fiacre, Monceau-sur-Sambre. Capital, 6,000,000 francs. This company owns interests in coal and iron mines and operated coke furnaces, blast furnaces, a steel plant, rolling mills, and construction shops. It acquired 40 hectares of rich mineral lands in 1904 from the Lothringen Hütten und Bergwerks Verein. The coke plant consisted of two groups of ovens at Monceau. The company operated three blast furnaces and a steel plant consisting of three Thomas converters, each of 12 tons capacity, a mixer, and three sets of rolling mills. The daily capacity of this company was approximately 260 tons of steel.

Usines de Moncheret, Moncheret. Capital, 1,250,000 francs. This company owns and operated iron and coal mines and a coke plant consisting of 125 ovens. The iron 
mines are in French Lorraine, and their ownership is shared with the Société d'OugréeMarihaye and the Société d'Espérance-Longdoz et Dillingen. The metallurgic plant consisted of a blast furnace and a steel converter of 100 tons daily capacity. The rolling mill had seven trains, or rolls, suitable for the production of semifinished and finished products. This company also operated a foundry producing iron and copper castings.

Hauts fourneaux, fonderies et mines de Musson, Musson. Capital, 1,500,000 francs. - A portion of the stock of this company is held by the Societe des forges d'Acoz, which therefore shares its considerable mineral interests in Luxemburg and French Lorraine. The metallurgic plant consisted of two blast furnaces having a daily capacity of 130 tons of foundry iron. The principal product of this company was iron castings.

Société d'Ougrée-Marihaye, Ougrée-lez-Liége. Capital, 75,000 shares with no par value; 52,725,000 francs capital stock in circulation (mixed German, Luxemburgian, and Belgian). This company owns and operated iron mines in Luxemburg and French Lorraine, coal mines, a coking plant, and a complete metallurgic plant for the production of finished iron ore and steel products. The company controlled and operated metallurgic installations and mining and metallurgic companies, consisting of the five Marihaye coal mines, the Ougree mine, and a five-eighths interest in the Charbonnage des Six Benniers. These mines produce 700,000 tons of coal and 270,000 tons of coke per annum. The company also owns the Bray coal mine. The mineral lands owned or controlled by this company are in Luxemburg and French Lorraine and amount to 2,800 hectares. The metallurgic plant at Ougrée consisted of eight blast furnaces and a steel plant, and had an annual production of 500,000 tons. The rolling mills produce finished steel products. There was also a foundry, a forge, and shops for the manufacture of steel structures. At Rondange the company operated a Thomas converter and a rolling mill having an annual capacity of 125,000 tons. This output was handled entirely by the Stahlwerks Verband. At Chiers this company operated three blast furnaces and a steel plant. This company owns the controlling interest in the Usines à tubes de la Meuse, organized in 1911. Four of the eight blast furnaces were entirely demolished, and the others were damaged. It was thought that at least two furnaces would be in operation before the end of the year 1919 .

La Providence, Marchienne-au-Pont, Belgium, and Rehon, Meurthe-et-Moselle, France. Capital, 18,000,000 francs (Belgian and French). This company owns and operated iron and coal mines and coking and metallurgic plants in Belgium and France. It also owns or has interests in important and valuable mineral concessions in the vicinity of Brainville, Godbrange, and other parts of French Lorraine, and in the coking plants at Terneuzen and at Willebroek. The metallurgic plant at Marchienneau-Pont consisted of five blast furnaces, a steel plant, which consisted of four Thomas converters of 15 tons each, blooming mill, and rolling mill for the production of finished steel products. This plant had a daily production of 650 tons of steel. There was also an iron foundry. The five blast furnaces were entirely demolished. This company operated at Rehon three blast furnaces, a steel plant, a blooming mill, a mill for the production of finished products, and an iron foundry. At Hautmont, France, it operated a Martin steel furnace, a steel rolling mill, and an iron and copper foundry.

Société métallurgique de Sambre-et-Moselle, Montignies-sur-Sambre. Capital, 23,500,000 francs (some Belgian capital but controlled by German capital). This company owns and controls coal and iron mines in Lorraine Annexée and coal mines in Belgium and the Sarre district. Metallurgic plants are located at Mézières and at Montignies-sur-Sambre. The metallurgic plant at Montignies consisted of a coking plant, three blast furnaces, and a steel plant which had a daily production of 900 tons. There was also a rolling mill, a forge, a foundry, and machine shops for the production and construction of finished steel products and structures. The three blast furnaces were damaged by the Germans, but they could be put in operation sometime in July, 1919, provided the materials necessary for the repairs could be delivered 
before the middle of April. This company owned a controlling interest in the Phenix works at Flémalle-Haute.

Hauts fourneaux du Sud de Châtelineau, Châtelineau. Capital, 1,500,000 francs. This company operated one blast furnace producing special grades of iron and manufacturing special grades of steel. The daily production was about 100 tons. This furnace was damaged by the Germans but was to be repaired and ready to operate by the 1st of July, 1919.

Hauts fourneaux, forges et aciéries de Thy-le-Château et Marcinelle, Marcinelle. Capital, 6,000,000 francs. This company owns interests in coal mines and in ironore concessions in Luxemburg. The metallurgic plant at Marcinelle consisted of two groups of coke furnaces, four blast furnaces, a Thomas converter with mixer, a rolling mill for the production of semifinished and finished products, a foundry, and machine shops. The daily capacity of this plant was 520 tons. The four blast furnaces were damaged but could be put in working order before the end of the year.

\section{GERMAN OWNERSHIP.}

In the following table are listed the iron and steel companies operating in Belgium known to have had a German directorate or to have included substantial German interests. There was also a substantial German ownership in the Société d'Ougrée-Marihaye, which had a total of 56,422,500 francs in outstanding capital stock and other obligations. The production of the Rondange division of this company, approximately 125,000 tons of steel annually, was sold through the Stahlwerks Verband. There are in addition scattered German holdings of which no accurate account could be made. It is estimated that 17 per cent of the capital stock of all Belgian iron and steel companies was owned by Germans prior to the war. 
IRON AND ASSOCIATED INDUSTRIES OF L̇ORRAINE, ETC.

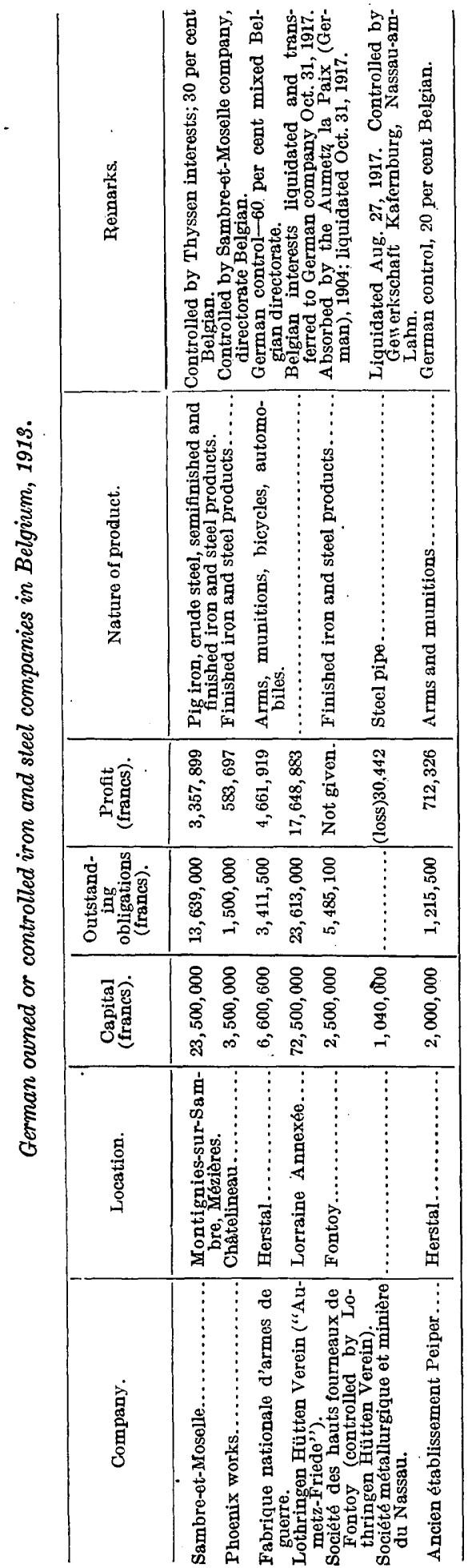


MINES AND PLANTS.

Belgian iron mines.

\begin{tabular}{|c|c|c|c|}
\hline Company and location. & $\begin{array}{c}\text { Area of } \\
\text { conces- } \\
\text { sions(hec- } \\
\text { tares). }\end{array}$ & $\begin{array}{l}\text { Period of } \\
\text { mining } \\
\text { activity. }\end{array}$ & Reason for stoppingoperations. \\
\hline 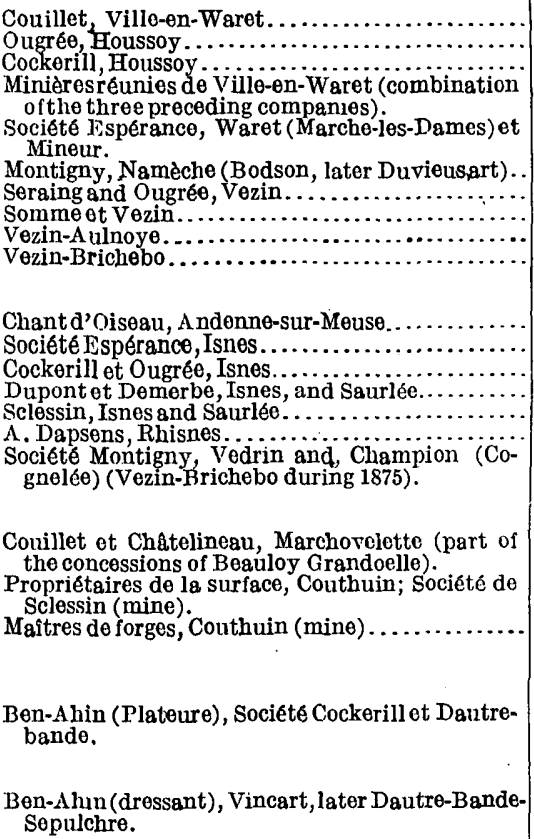 & 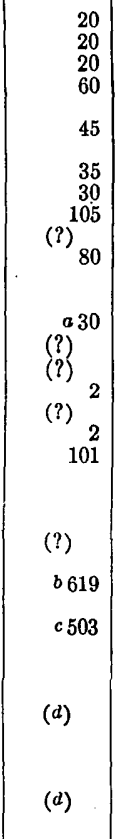 & $\begin{array}{r}1849-1873 \\
1846-1880 \\
1849-1876 \\
1880-1901 \\
1856-1864 ? \\
1855-1874 \\
1856-1886 \\
1851-1895 \\
1873 \\
1853-1883 \\
\\
1874- \\
1858-1862 \\
1851-1866 \\
1860 ?-1880 \\
1858-1877 \\
1866 ?-1866 \\
1858-1883\end{array}$ & $\begin{array}{l}\text { Do. } \\
\text { Do. } \\
\text { Exhaustion of exploitable ore. } \\
\text { Fire in 1883; minenot reopened } \\
\text { as rich ore had already been } \\
\text { extracted. } \\
\text { Operating in } 1912 \text {. } \\
\text { Only low-grade ore remaining. } \\
\text { Do. } \\
\text { Worked out; pillarsremaining. } \\
\text { Outcrops impassable. } \\
\text { Ore of low grade. } \\
\text { During 1875 mining was re- } \\
\text { duced as ore was of lowgrade. } \\
\text { Fire in Vezin mine caused } \\
\text { final shut down. } \\
\text { Ore bed thinned out and could } \\
\text { not be profitably worked. } \\
\text { Mined out. } \\
\text { Upper ore mined out. In order } \\
\text { to mine at depth the Java } \\
\text { shgit must be used and new } \\
\text { surface rights obtained. } \\
\text { Ore mined abovelevel of drain- } \\
\text { age gallery. Pumping ex- } \\
\text { pensetoo greatto mine below } \\
\text { this level. }\end{array}$ \\
\hline
\end{tabular}

a In 1878; increased since. b 70 exploitable. c150 exploitable.

d2,500 meters of development along outcrop of bed. 
112 IRON AND ASSOCIATED INDUSTRIES OF LORRAINE, ETC.

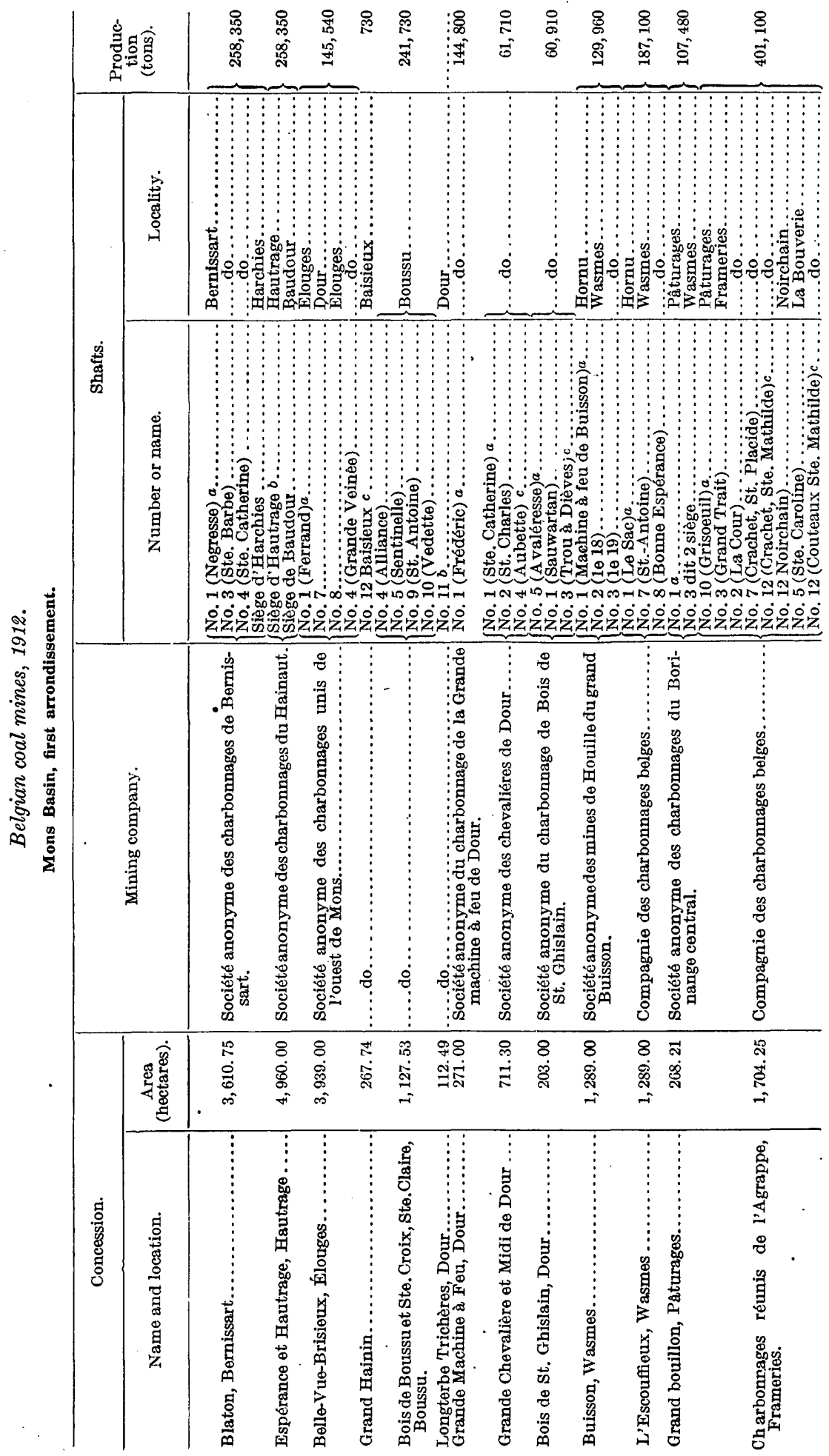


BELGIUM.

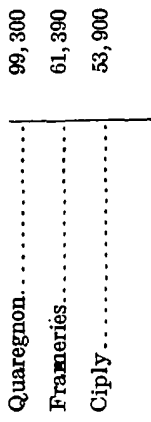
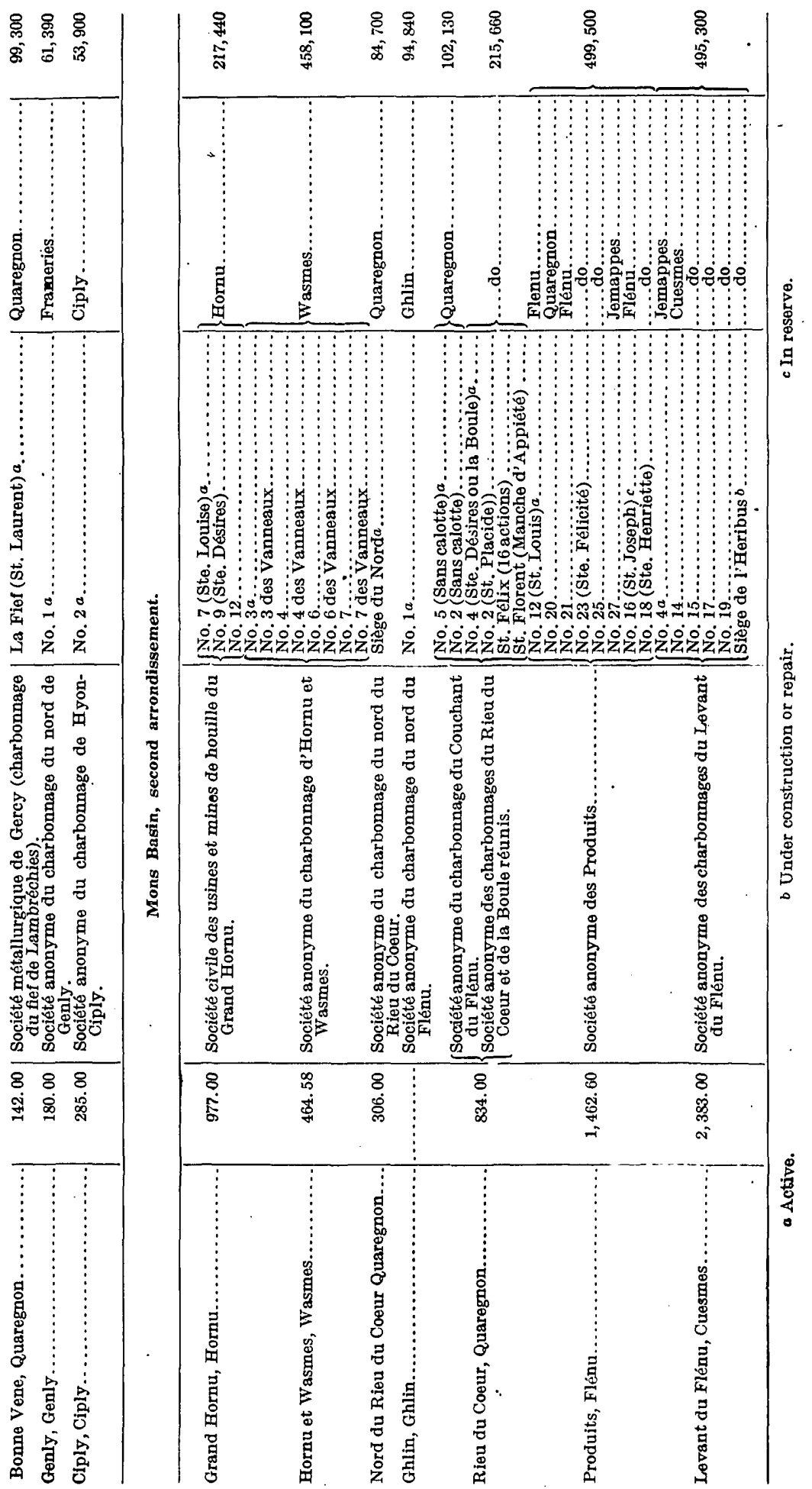

$187234^{\circ}-20-$ Bull. $703-8$ 
114 IRON AND ASSOCIATED INDUSTRIES OF LORRAINE, ETC.

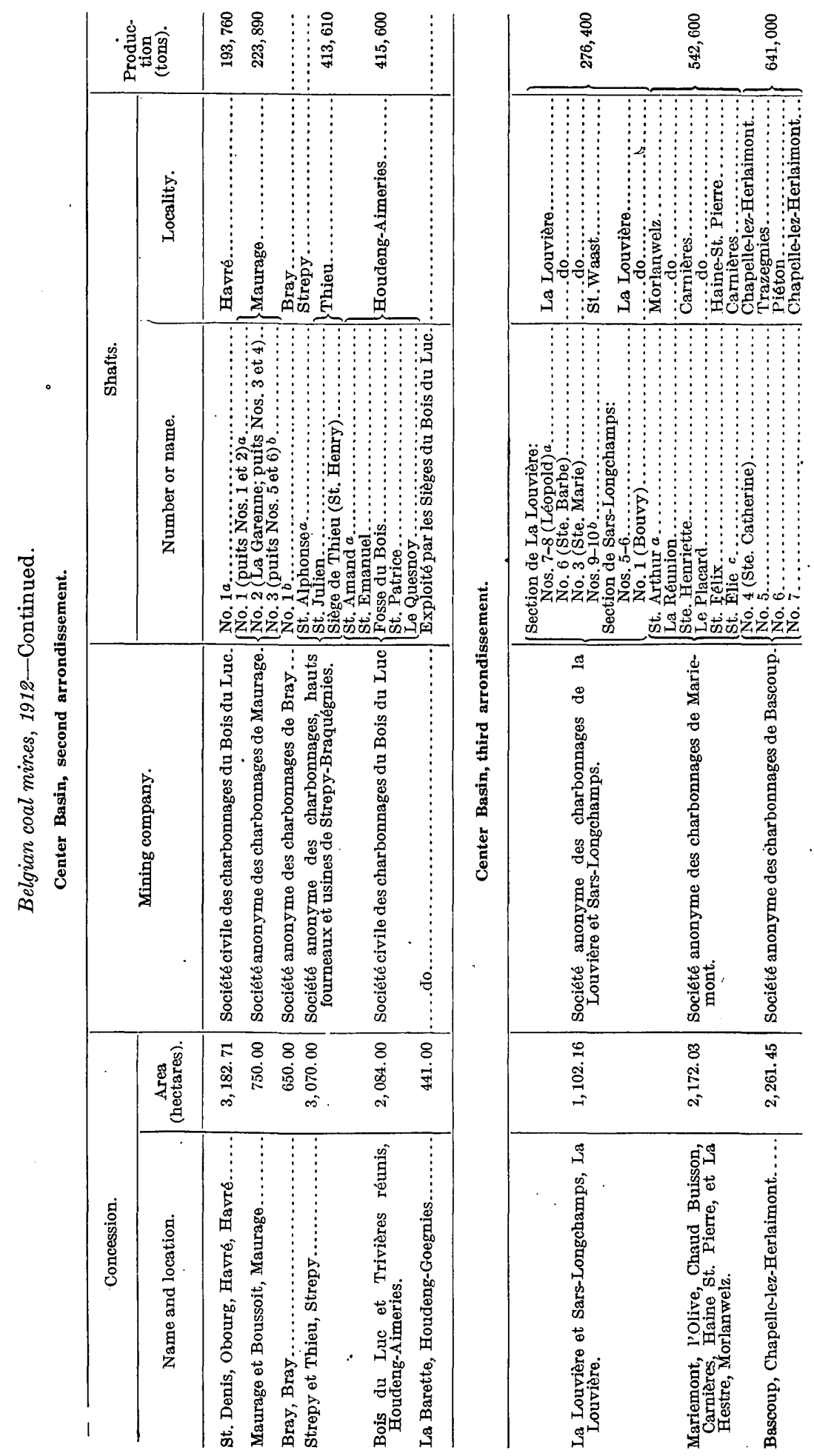


BELGIUM.

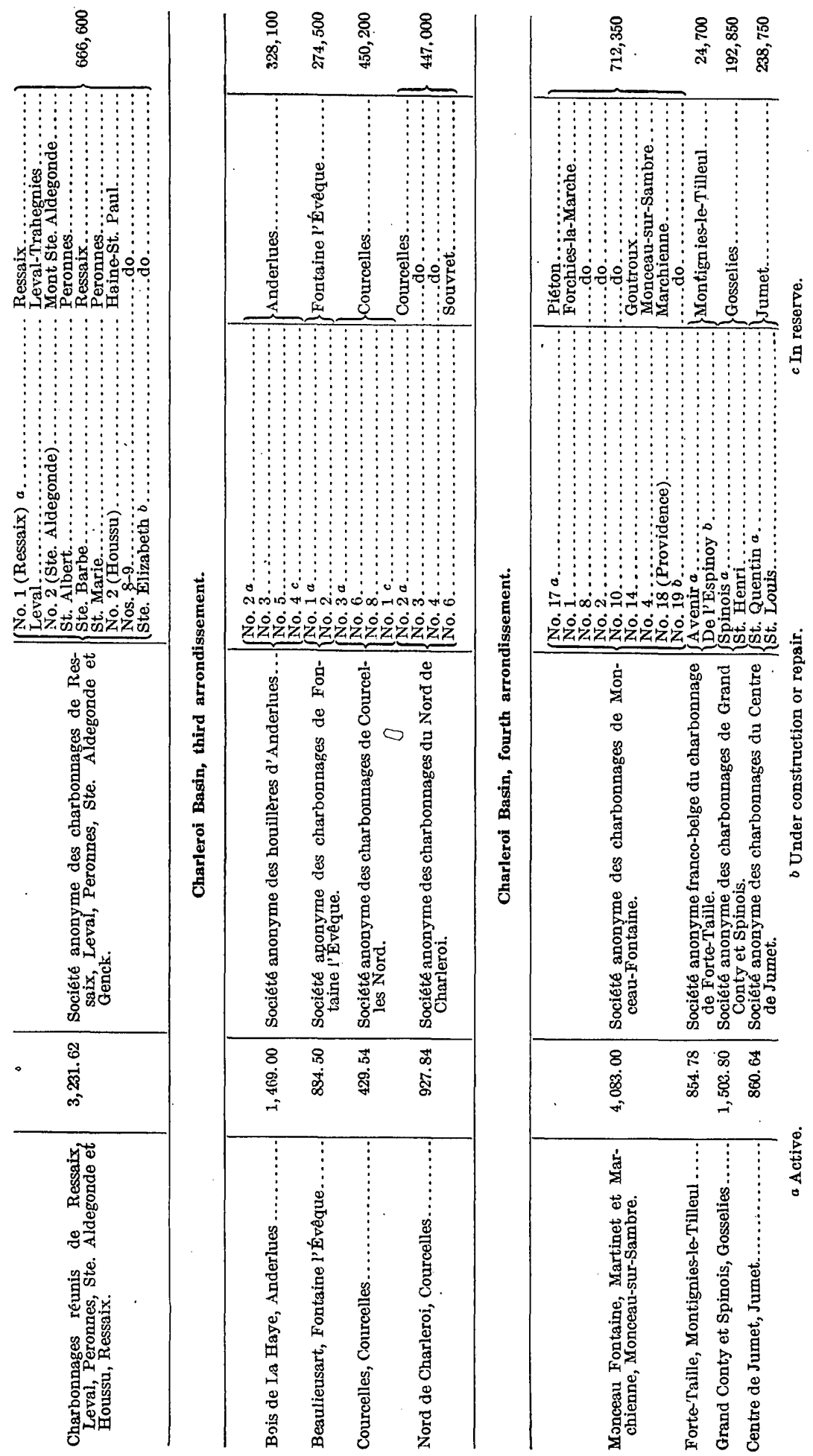


116 IRON AND ASSOCIATED INDUSTRIES OF LORRAINE, ETC.

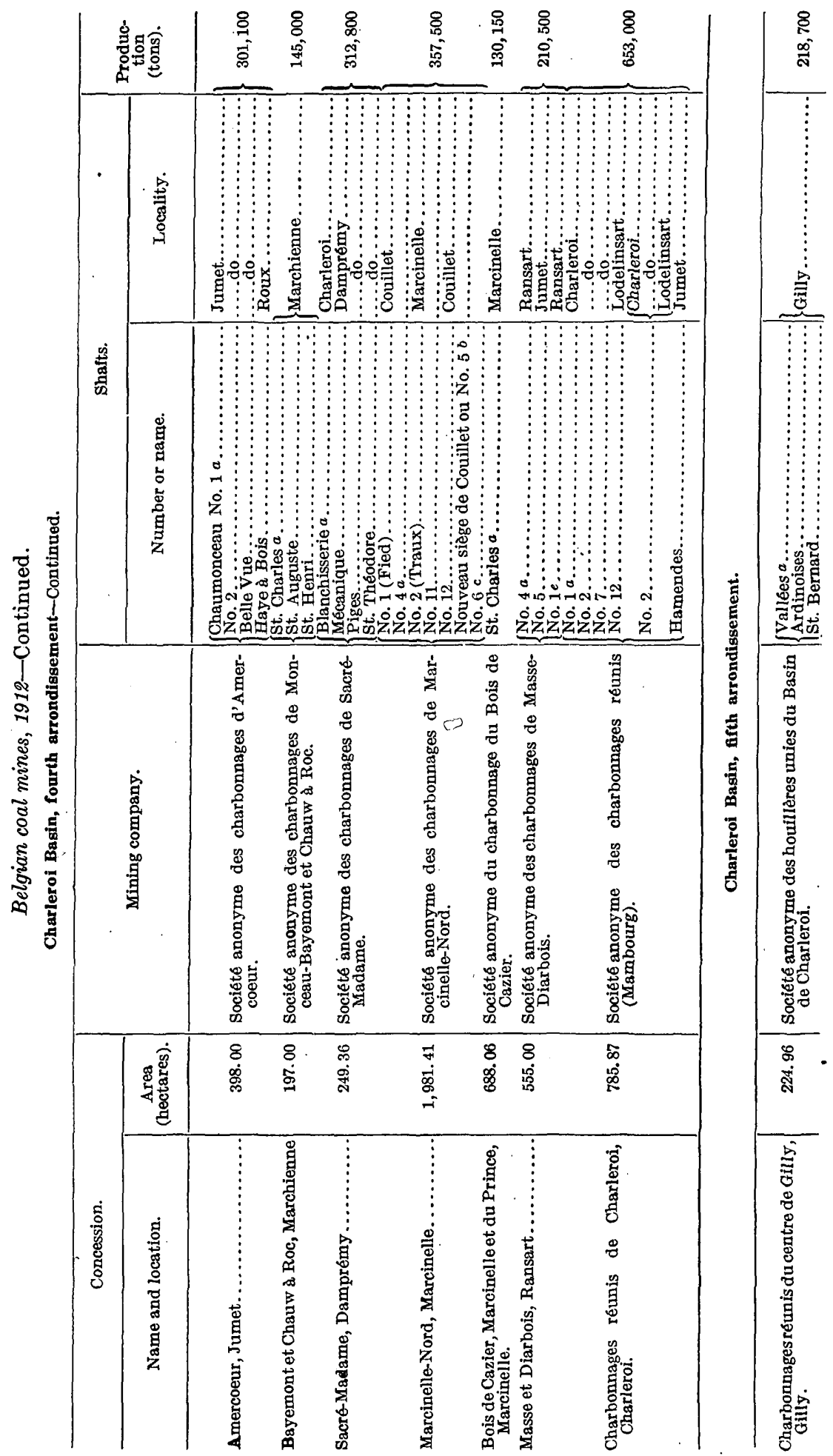




\section{8 유 융 \& \&

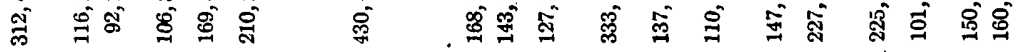

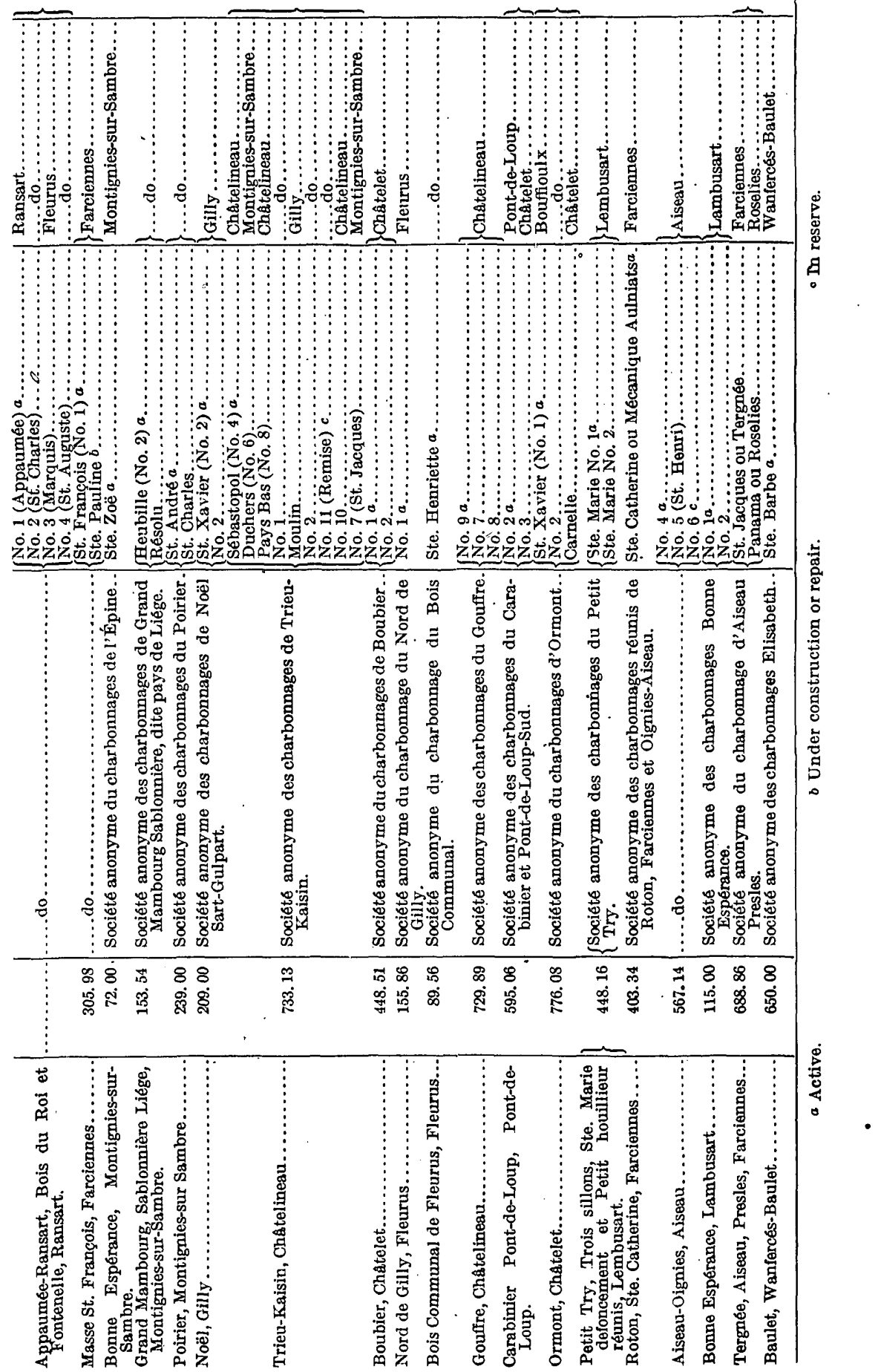


118 IRON AND ASSOCIATED INDUSTRIES OF LORRAINE, ETC.

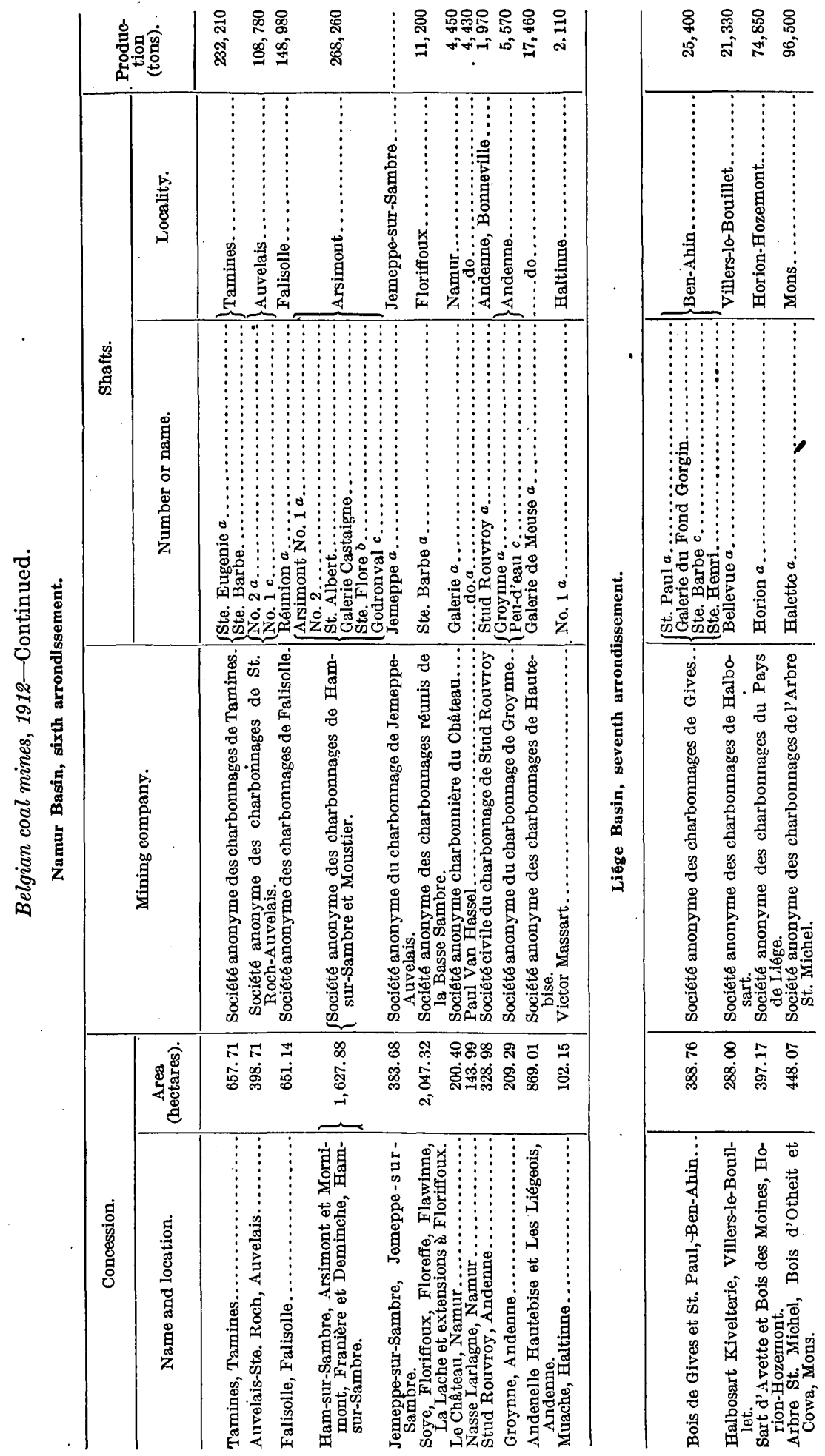




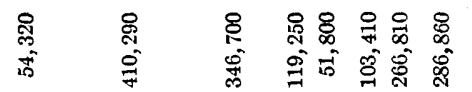

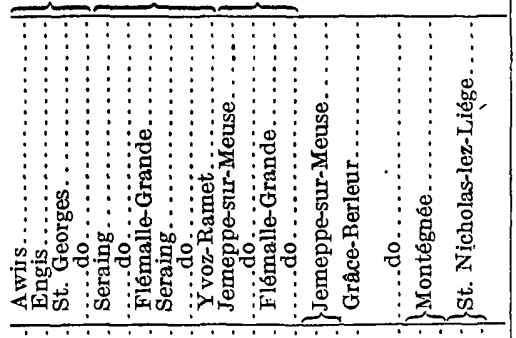

\section{옹유 융 영 웅 웅

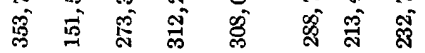

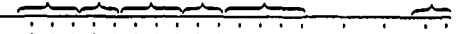

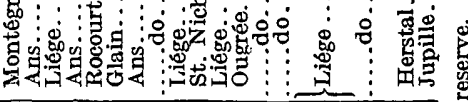

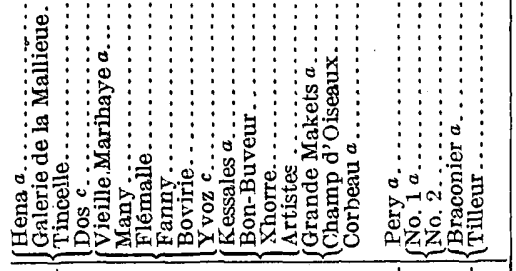

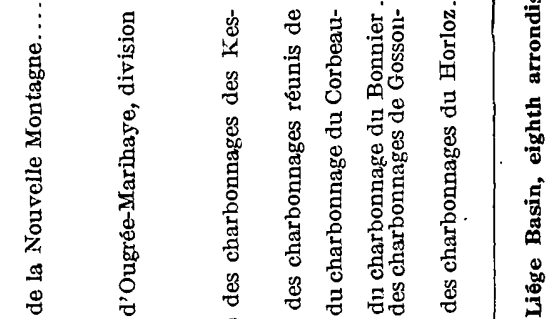

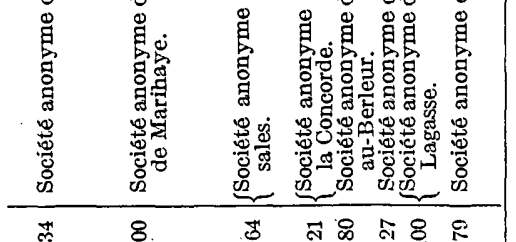

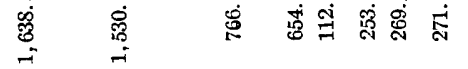

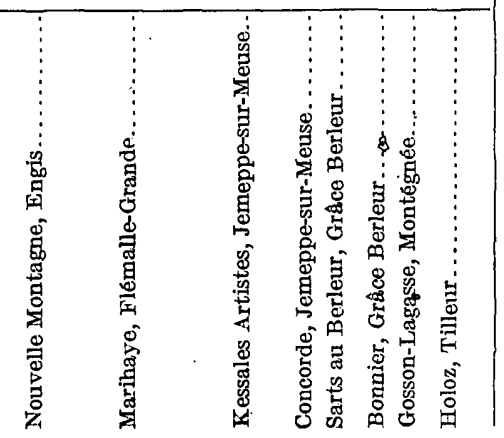

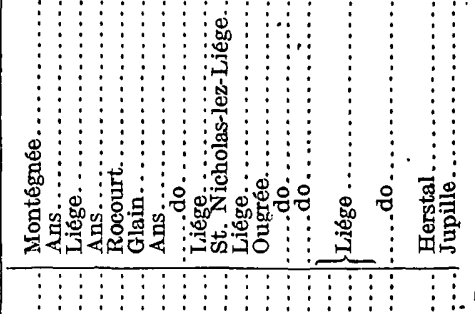

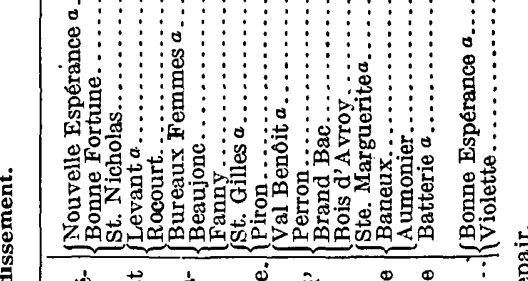

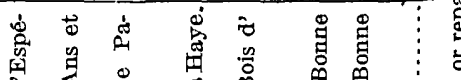

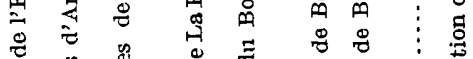

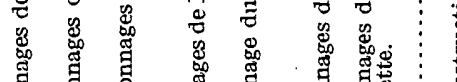

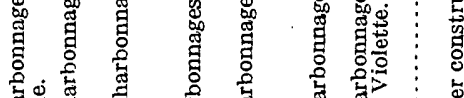

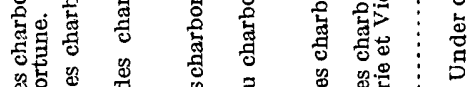

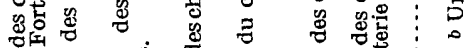

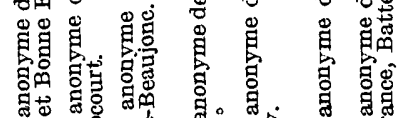

$\underbrace{0} \underbrace{0}$

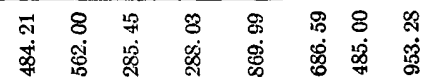

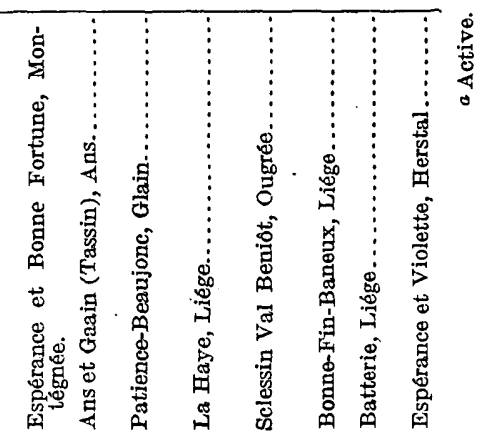



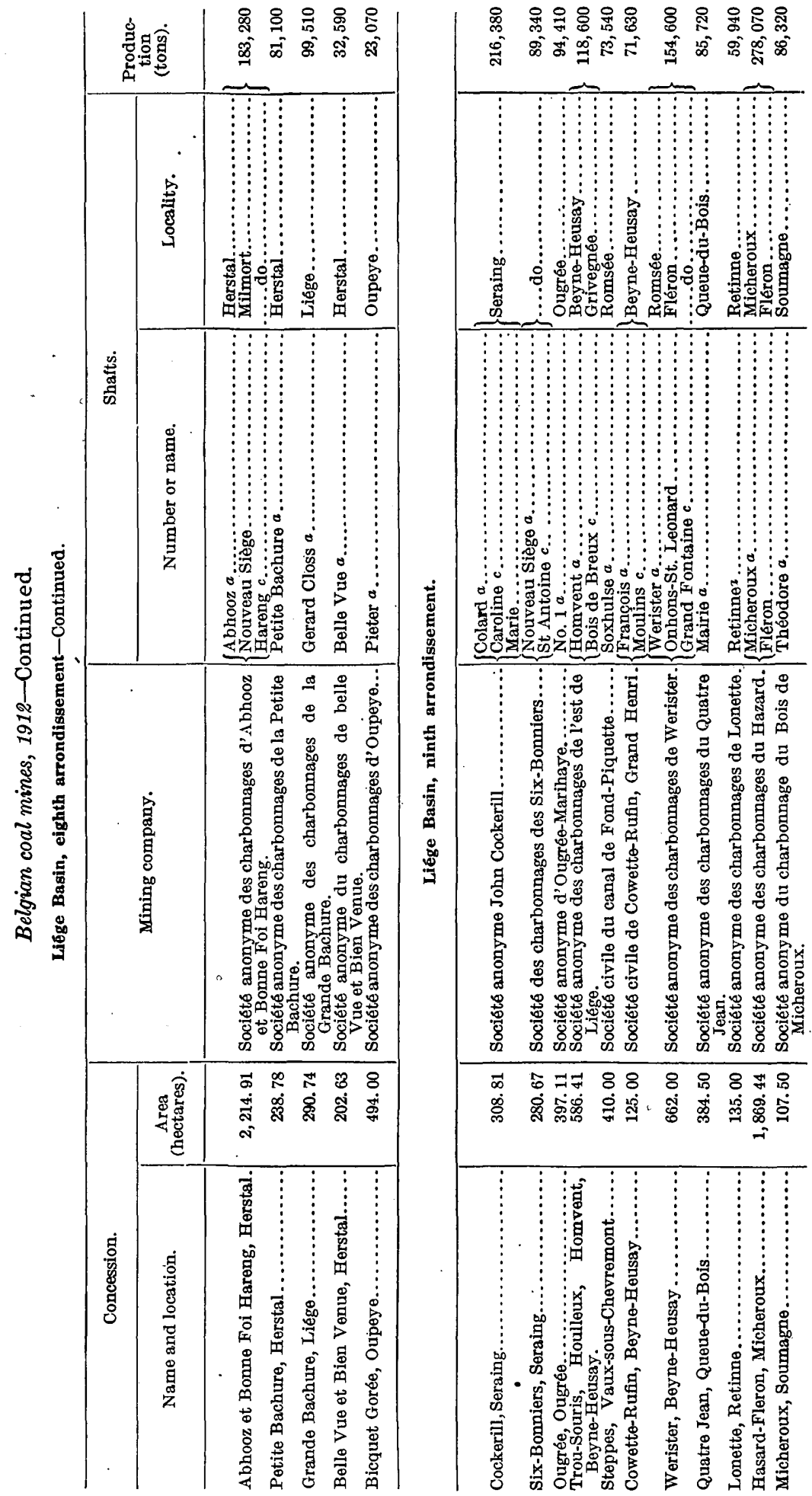


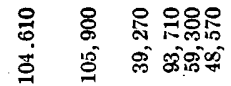

0
$\vdots$
0
0

藏

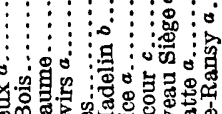
孔
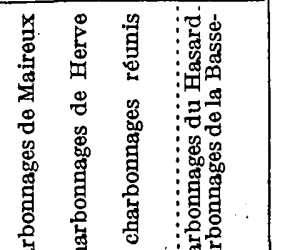

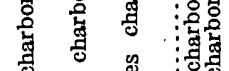

焉

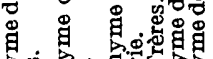

的。

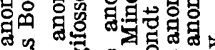
$\Phi$ 要

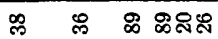

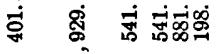

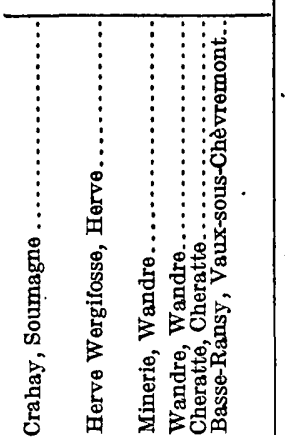

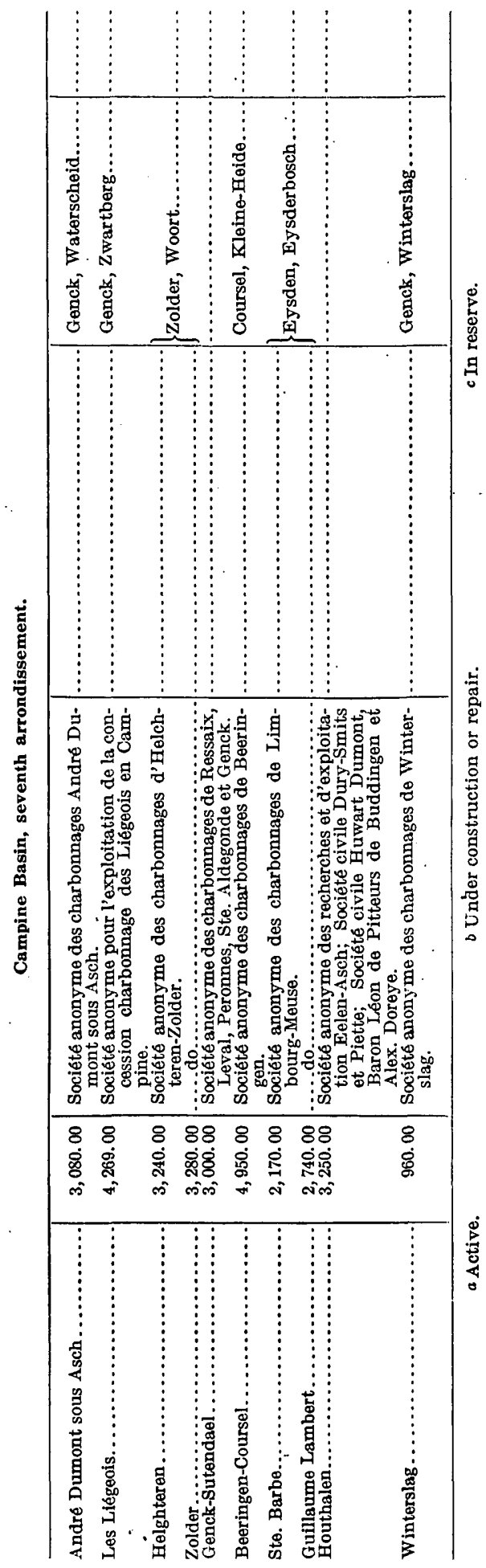




\begin{tabular}{|c|c|c|c|c|c|c|c|c|c|c|c|c|c|c|c|}
\hline & 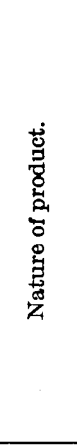 & 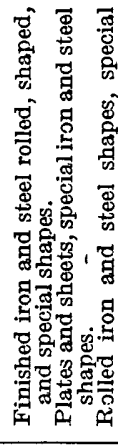 & 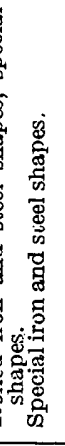 & 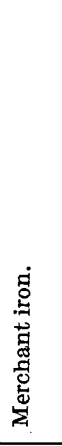 & 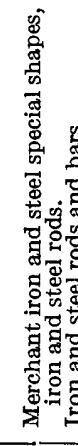 & 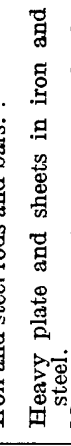 & 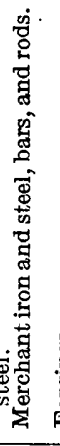 & r. & 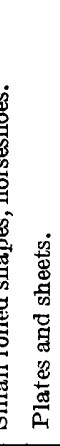 & 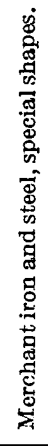 & 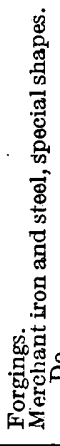 & 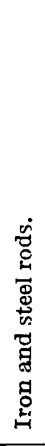 & 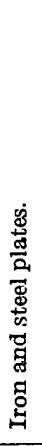 & & $\dot{\AA}$ \\
\hline & 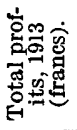 & 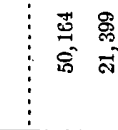 & $\begin{array}{l}8 \\
0 \\
8 \\
8 \\
6\end{array}$ & & 品 & 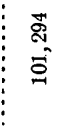 & 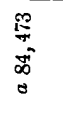 & & & & & 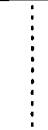 & & & 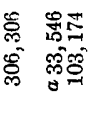 \\
\hline & 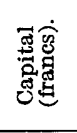 & 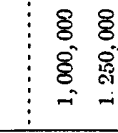 & $\begin{array}{l}8 \\
8 \\
8 \\
8 \\
0 \\
-\end{array}$ & & $\begin{array}{l}8 \\
8 \\
8 \\
8^{-}\end{array}$ & $\begin{array}{l}8 \\
8 \\
8 \\
\text { - } \\
\text {-i }\end{array}$ & $\begin{array}{l}8 \\
80 \\
8 \\
\text { si }\end{array}$ & & & & & & & & 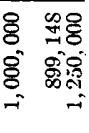 \\
\hline 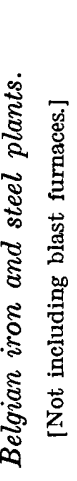 & 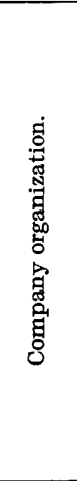 & 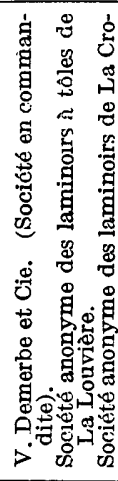 & 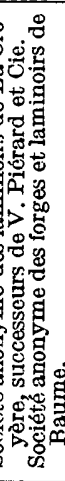 & 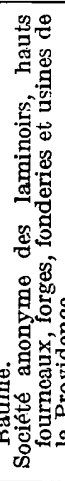 & 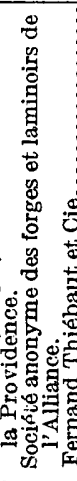 & 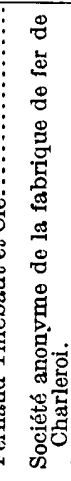 & 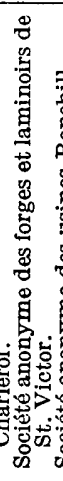 & 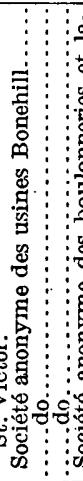 & 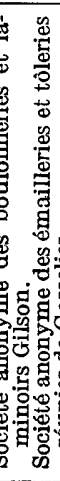 & 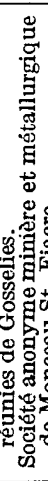 & $\vdots$ & & 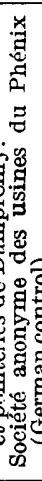 & 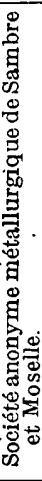 & 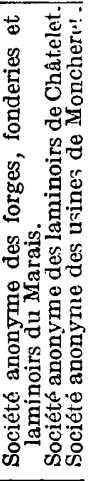 \\
\hline & 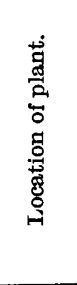 & 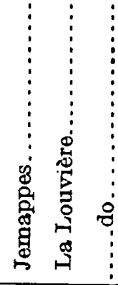 & 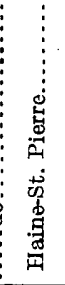 & 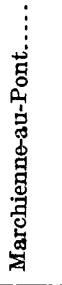 & ఏ: & : & 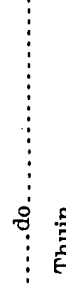 & 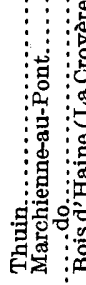 & 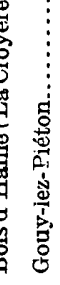 & 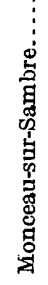 & 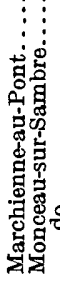 & 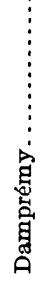 & 苞 & 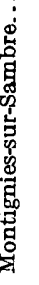 & 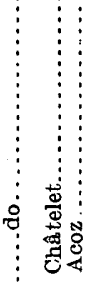 \\
\hline & : & 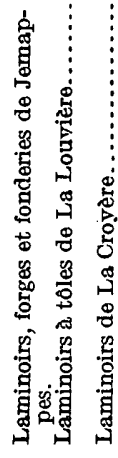 & 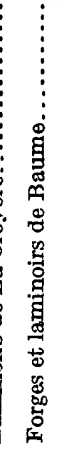 & 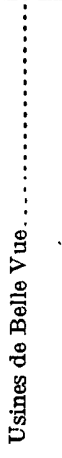 & 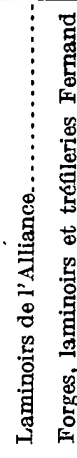 & 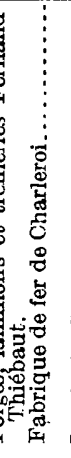 & 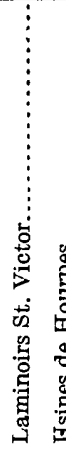 & 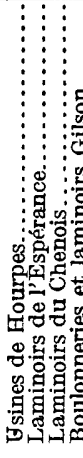 & 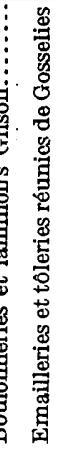 & 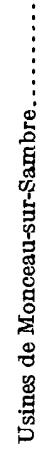 & 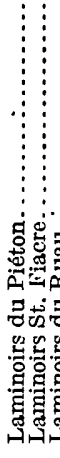 & 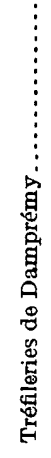 & $\begin{array}{l}\vec{q} \\
\mathrm{~g}\end{array}$ & & 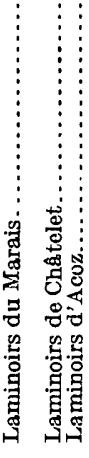 \\
\hline
\end{tabular}




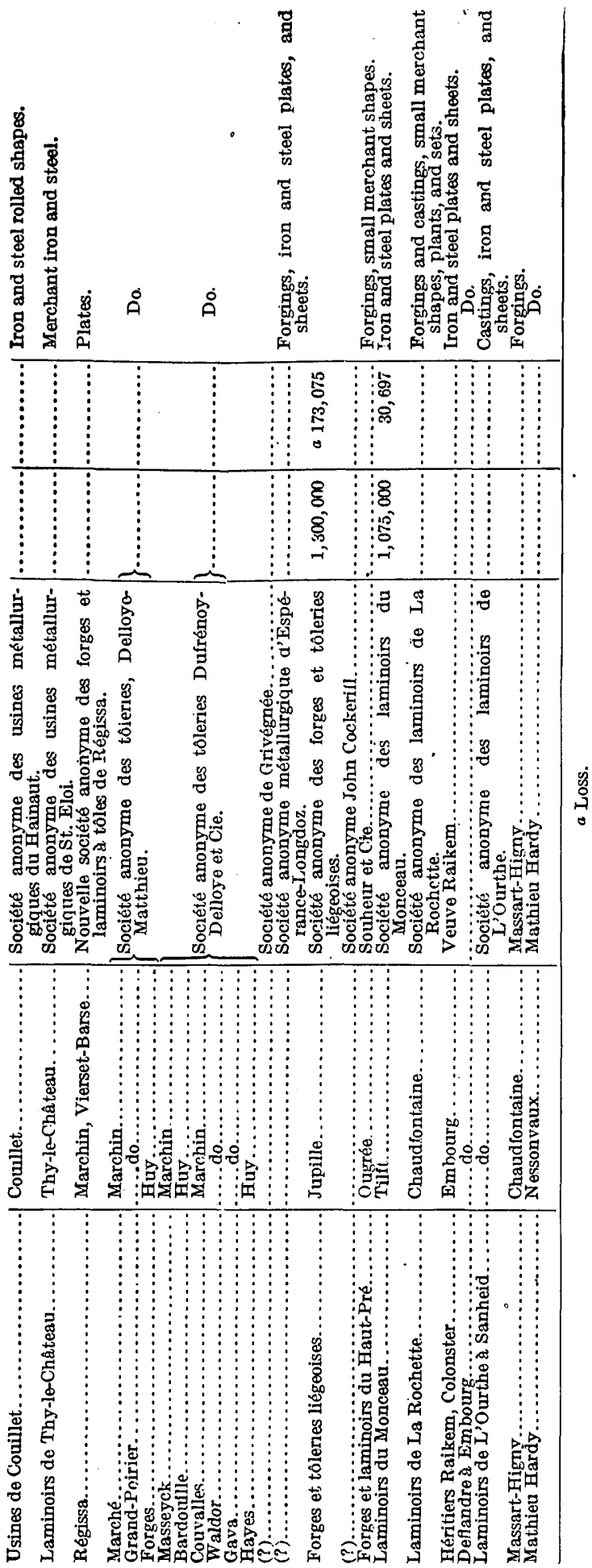


124 IRON AND ASSOCIATED INDUSTRIES OF LORRAINE, ETC.

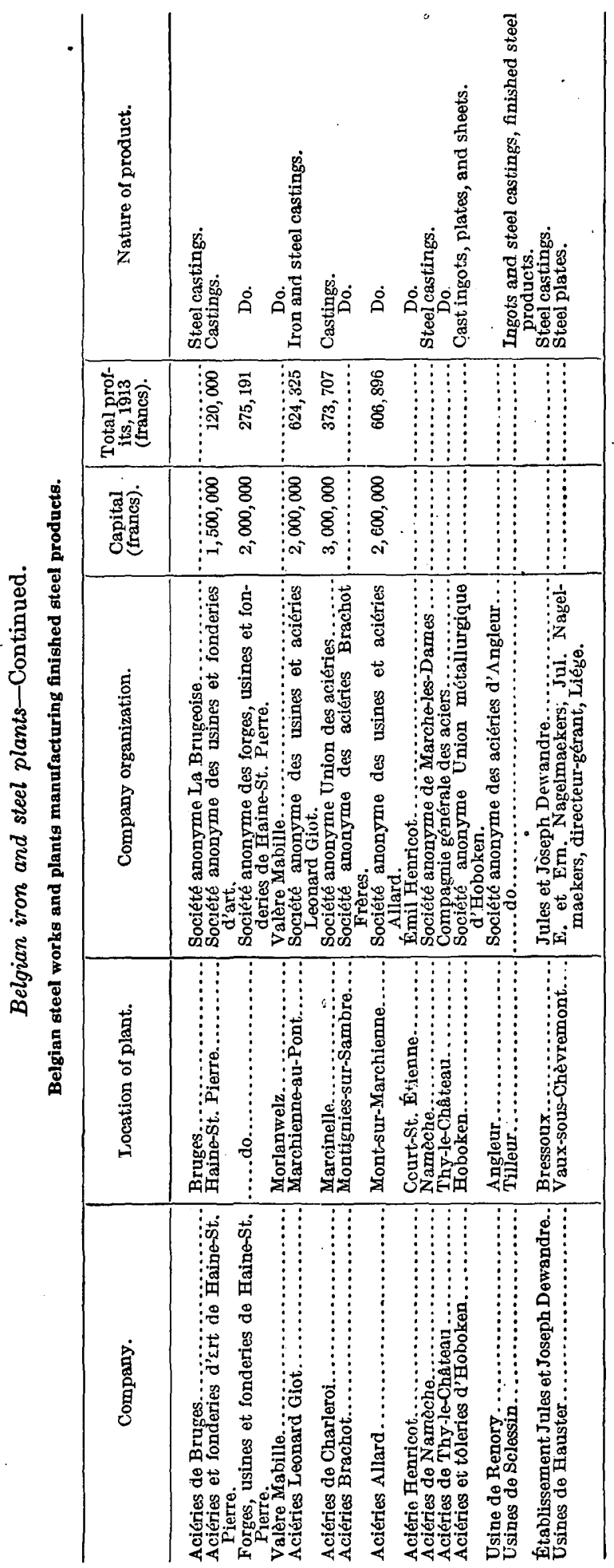




\title{
PRINCIPAL WORKS CONSULTED.
}

\author{
Compiled by Harold F. Crooks.
}

L'Allemagne peut payer, Paris, Bernard Grosset, 1919.

L'Alsace-Lorraine et la frontière du nord-est, vol. 1 (secret), par le Comité d'études, Paris, Imprimerie national, 1918.

Annales des mines de Belgique, 1904 to 1916, inclusive, Brussels, Ministère de l'industrie et du travail, Administration des mines.

Annales des mines de France, 1904-1914, inclusive, Paris, Dunod et Pinat.

Annuaire du Comité des forges de France, 1914-15, Paris.

Annuaire du Comité général des houillères de France, 1914, Paris.

Annuaire de la Société des aciéries de Longwy, 1913, Mont-St. Martin, Meurthe-etMoselle.

Annuaire statistique de la Belgique et du Congo belge, vol. 44, for 1913, Brussels, Imprimerie A. Lèsigne.

Annuaire statistique, Statistique général de la France, vols. 24-34, Paris, Ministère du travail et de la prévoyance sociale, 1904-1914.

Atlas général des houillères, by E. Gruner and G. Bousquet, part 1, maps; part 2, text, Paris, Ch. Béranger, 1911.

Bülletins de la Comité des forges de France, 1904-1917, Paris.

Bulletins de la Comité des houillères de France, 1904-1917, Paris.

Cartes d'étude des bassins miniers de l'Europe occidentale, Paris; Comité dẹ forges de France.

Le charbon dans le nord de la Belgique, by G. de Leener, L. Wodon, and E. Waxweiler, Brussels, Institut de sociologie, 1904.

The coal resources of the world, vols. 1-3, 12th International Geologic Congress, Toronto, Canada, Morang \& Co., Ltd., 1.913.

Les concessions minières dans le Grande-Duché de Luxemburg, by Victor M. Dondelinger, Luxemburg, Charles Beffort, 1912.

Congrès général du génie civil, section 4, Mines et métallurgie, Rapports, Paris, Hotel de la Société des ingénieurs civils, 1918.

The cost of mining, by James Ralph Finlay, New York, McGraw-Hill Book Co., 1910. Le charbon, by C. Robert Muller, Paris, Association national d'exposition économique.

Colliery Guardian and Journal of the Coal and Iron Trades, London, 1904-1914.

Carte des bassins miniers et métallurgiques lorrains and luxembourgeois, $2^{\circ}$ Bureau de l'état-major de l'Armée (section économique), 1917.

Carte géologique de la France, sheets as follows: Metz, 1900; Longwy, 1902; Commercy, 1887; Nancy, 1882, Paris, Service de la carte géologique de la France.

L'Écho des mines et de la métallurgie, Paris, 1912, 1913, 1914.

Die Ergebnisse der geologischen Forschungen in Elsass-Lothringen und ihre Verwendung zu Kriegszwecken, 1916, by Leopold von Werveke; Wiss. Gesell. Strassburg, Schriften, Heft 28, Strassburg, Karl J. Trubner.

La France de l'est, by Vidal de la Blache, Paris, 1917.

Le fer et le charbon, by Honoré Paulin, Paris, Bossard, 1919.

Le fer en Lorraine, by E. Grenau, Paris, Berger-Levrault et Cie., 1908

Le génie civil, vols. 56-71, Paris, 1912-1917.

Geographie physique de la Lorraine, by Henry Joly, Nancy, 1912.

Géologie du bassin de Paris, by Paul Lemoine, Paris, 1911.

Gemeinverständliche Darstellung der Eisenhüttenwesens, Dusseldorf, Verlag Stahleisen m. b. H., 1910.

Glückauf, Essen (Ruhr), Verein für die bergbaulichen Interessen, 1904-1917.

Handbuch der Deutschen Aktien-Gesellschaften, Ausgabe 1917-18, Band II; Ausgabe 1918-19, Band I, Berlin und Leipzig, Verlag für Borsen und Finanzliteratur A. G. 
Les houillères françaises durant la guerre, by Auguste Palowski: La Nature, No. 2248, pp. 274-277, Paris, October 28, 1916.

L'Illustration, 8 mars 1919, Paris, René Baschet.

L'industrie de l'acier en France, by J. Bribot-Laspière, Paris, Librairie Vuibert, 1916.

L'industrie du fer, by Louis Ferasson, Paris, Payot et Cie., 1918.

Les industries métallurgiques à l'avant-guerre, by Léon Guillet, Paris, H. Dunod \& E. Pinat, 1917.

The Ironmonger, London, 1910-1914.

Iron-ore resources of the world, vols. 1-3, 11th International Geological Congress, Stockholm, 1910.

Journal officiel de la République française, Paris, 1914-1919.

Liste des établissements métallurgiques, April 1, 1914, Brussels, Administration des mines, Ministère de l'industrie et du travail, 1914.

Lorraine and Saar mine fields, London, British Foreign Office, Historical Section, 1919.

Le minerai de fer de Lorraine, by L. Cayeux: Travaux de Comité d'études, Section géologique, Paris, Imprimerie National, 1919.

A manual of Belgium and adjoining territories, Atlas (secret), British Naval Staff, Intelligence Division, 1918.

Manuel du mineur, by Paul F. Chalon, Paris, Ch. Beranger, 1909.

La métallurgie du fer, by Paul Doumer and others, Paris, Librairie Vuibert, 1912.

La métallurgie du fer, by Pierre Grillet, Paris, Association national d'expansion économique, 1919.

La métallurgie et l'après-guerre, by Robert Pinot: Soc. ind. minérale Bull., vol. 11, pp. 5-37, St. Étienne, 1917.

Moselland und westdeutsche Eisenindustrie, Band 2, by Prof. Dr. Hermann Schumacher, Leipzig, Verlag von Duncker et Humbolt, 1910.

Le mouvement des combustibles minéraux sur les voies navigables belges, by $\mathrm{A}$. Delmer, Brussels, Lucien Narcisse, 1919.

Die Neuentwicklung des lothringischen Eisenerzbergbau, by Dr. Kohlman: Stahl und Eisen, vol. 31, pp. 413-424, 469-479, 544-556, 1911.

Notices descriptives et statistiques [on the various departments and provinces of Belgium, France, and Germany coming under the scope of this report], Bordeaux, Ministère de la guerre, État-major de l'Armée, $2^{\ominus}$ Bureau.

Participation des sociétés belges de distribution d'électricité et de traction électrique, Exposition internationale et universelle de Gand, Brussels, Union des exploitations électriques en Belgique, 1913.

La province rhénane et la Westphalie, by Yves Guyot, Paris, Attinger Frères, 1913.

La question du fer, by Louis Ferasson, Paris, Payot et Cie., 1918.

La question des minerais de fer en Belgique, by A. Delmar: Annales des mines de Belgique, vol. 17, pp. 850-853, 1912; vol. 18, pp. 325-348, 1913.

Rapport général sur la situation de l'industrie et du commerce pendant l'année 1911, Grand-duché de Luxembourg, Luxemburg, Imprimerie de la Cour, Vịctor Buck, 1912.

Rapports des ingénieurs des mines aux conseils généraux sur la situation des mines et usines en 1904 à 1912, Paris, Comité central des houillères de France.

Rapport sur la situation de l'industrie minéral et métallurgique dans la province de Liége, 1911, 1912, 1913, Liége, M. Thone.

Le recueil financier, Brussels, Emile Brayland, 1918.

Région comprise entre la Meuse et le Rhin; Bassins miniers et métallurgique, Paris, Commission de géographie du Service géographique de l'Armée, Ministère de la guerre, 1917.

Report of mines and quarries section, American Commission to Negotiate Peace, War Damage Board, 1919, vol. N. IV; vol. H; vol. F. 
Les ressources de la France en minerais de fer, by P. Nicou, Paris, Dunod et Pinat, 1911.

Revue universelle des mines et de la métallurgie, Paris, H. Le Soudier, 1904-1914.

Die Schwedische Eisenerzfrage: Stahl und Eisen, vol. 27, pp. 533-534, 1907.

Stahl und Eisen, vols. 29-32, Dusseldorf, 1904-1913.

Statistics: Iron and Steel Inst. Jour., vol. 87, pp. 698-719, London, 1913.

Statistique des industries extractives et métallurgique en Belgique, 1904 to 1916, Brussels, Ministère de l'industrie et travail, 1905-1918.

Statistique de l'industrie minérale en France et Algérie, 1904 to 1913, Paris, Ministère des travaux publics et des transports, Direction des mines, 1906-1917.

Le sol et les populations de la Lorraine et des Ardennes, by Commandant Chênet, Paris, Librairie Ancienne Honoré Champion, 1916.

Traité de géologie, by A. de Lapparent, 4th ed., Paris, Masson et Cie., 1900.

Vierteljahreshefte zur Statistik des Deutschen Reiches, Berlin, 1904-1915. 



\section{INDEX.}

0

A. Page.

Acknowledgments for aid................. 11,12

Aix-la-Chapelle coalfield, features of........ $\quad 25$ reserves in ......................... 27 Antwerp Province, Belgium, cosl beds in... 88-89

\section{B.}

Bavarian Government, holdings of, in coal lands and mines in the Sarre district.................... 30,74,79

Belgians, holdings of, in companies operating iron mines and works of French Lorraine.

holdings of, in companies operating iron mines and works of Lorraine Annexée............... 56,57, 58

in companies operating iron mines and works of Luxemburg. 61-62,65, 68 iron and steel works of the Sarre district................... 78,79

Belgium, position of, in the European iron industry...........9-10,35-37,80-81 war damage to iron and steel works of... 33 ,

See also Capital, Coal, Coke, Iron ore, Iron and steol products, $P$ ig iron, Steel, and the names of provinces.

Bibliography. $125-127$

Briey district, French Lorraine, iron ore in.

Bruggener-Erlselenz coal field, Germany, features of ....................

reserves in

\section{C.}

Campine Basin, Belgium, coalmining in. $88-89,121$ coal reserves in

Capacity of iron works smelting Lorraine ore

in $1919 \ldots \ldots \ldots \ldots \ldots \ldots \ldots . . . . . . .33-34$

in 1924 , estimated ................... 34-35

Capital, sources of, in iron and steel companies of Belgium................ 28, $30,83,106-109,122-124$

sources of, in iron and steel companies of French Lorraine..... 28-30,37-38, 43-50

in iron and steel companies of Lor-

raine Annexée......... 28-30,55-56 of Luxemburg. 28-30, 59, 61-62, 65, 67-70 of the Sarre district..... 28-30,75,78-80

Cartels, influence of.

Center district, Belgium, coal mining in..... 87 , $89,90,114-115$

Charleroi district, Belgium, coal mining in.. 87, 90, 115-117

Cosl, coking, consumption of, by iron industries in Belgium........... 9-10,26,97 $187234^{\circ}-20-9$
Coal, coking, consumption of, by iron industries in French Lorraine......... 26,43 coking, consumption of, by iron industries in Lorraine Annexée....... consumption of, by iron industries in the Sarre district.............. 76,77 cost of mining, in Belgium .......... 90-91 in the Sarre district............. 76 exports of, from Belgium......... 93,105 from the Sarre district.......... $\quad 77$ importation of, advisability of....... 37 imports of, into Belgium 91-92, 94-95, 97, 105 prices of.

production and reserves of, in Belgium........ 9, 26,27,89-91,112-121 in France............... 9, 20-24,27 in the Sarre district....... 27,73-74,78 in Westphalia............... 24-25 shipment of, from the Sarre district. $\quad 77$ sources of.................... 20,26-28 exports of, from France................ 23

Coal fields, Belgian, descriptions of........ 86-89 tributary to the Lorraine iron districts, maps showing......... 12, in pocket. Coke, consumption of, by iron industries in Belgium.................. 98 consumption of, by iron industries in French Lorraine .............. 43

by iron industries in the Sarre district $76-77$ exports of, from Belgium........... 95-96, 105 imports of, into Belgium......... 95-96, 98, 105 into France.................... 23-24 prices of ............................ 27 production of, in Belgium........... 93,95, 96

in France...................... 23-24

in the Sarre district............. 76-77

in Westphalia..................... 24-25

Cologne, lignite field near................. 25

Comité des forges de France, acknowledgment to..................... 12 Comité général des houillères de France, acknowledgment to.............. 12

Companies. See Capital.

Composition of iron ores.................. 38

Concessions for mining, areas covered by, in the Sarre district.............. 74

laws governing, in French Lorraine...... 38-39 in Lorraine Annexée.............. 51-52 in Luxemburg.................... 60 Crooks, Lieut. Harold F., acknowledgment to 12 principal works consulted, list of....... 125-127 Crusnes district, French Lorraine, iron orein. . 38 . D.

Damage to mines by Germans............. 22-23: Delmer, Dr. Alexandre, acknowledgment to. 12 Differdange Basin, Luxemburg, iron ore in.. $\quad 60$ 
E.

École des mines, Paris, acknowledgment to.... 12

England, export of Lorraine iron ore to...... 42

Europe, coal reserves of ................... 20,21 industries of, Americans need knowledge

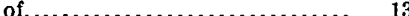

iron-ore reserves of.................. 16, 17

Exportation of Lorraine iron ore, advisability of...................

F.

France, position of, in the European iron industry..... 9,35

See also Capital, Coal, Coke, Iron ore, Iron works, Pig iron, Steel, and the names of regions.

Freight rates and routes to markets for Lorraine iron ore.

French, holdings of, in companies operating coal mines and iron works in Belgium...

holdings of, in companies operating iron mines and works in Lorraine Annexée...

in companies operating iron mines and works in Luxemburg. 61-62,65,68 coal mines and iron works in the Sarre district. 75,79

ownership by, of a coking plant in the Sarre district.

\section{G.}

Germans, holdings of, in companies operating iron and steel works in Belgium. $108,109-110$

holdings of, in companies operating iron mines and works in French Lorraine.................... $48,49,50$

in companies operating iron mines and works in Lorraine Annexée. 29-30,

iron mines and works in Luxem-

burg.......... 29-30,61-62,65,67-70 coal mines, coking plants and iron works in the Sarre district........... 29-30,75,77,78-80

iron lands in French Lorraine bought by.

Germany, requisition of iron and steel products from.

reserves of coking coal in........

of iron ore in..................... 16

use of Lorraine iron ore in........ 9-10,15-16 See also Sarre district and Westphalia.

H.

Haine-Sambre-Meuse Basin, Belgium, location and divisions of.......... $86-88$ coal reserves of

Hainaut Province, Belgium, coal mining in. coal reserves in coke produced ln

I.

Iron lands, holdings and prices of, in Luxemburg.
Iron mines, French, little damage to........ Page. Iron ore, composition of, in the Lorraine

field..................... 19-20,51

consumption of, in Belgium...... 32,82,36-97

in French Lorraine...... 32, 33, 35, 36, 41,42

in Europe...................... 14

in Lorraine Annexée............ 32,50,54

in Luxemburg............ 32,59,62,63,65 cost of mining, in French Lorraine.... 20,39-40

in Lorraine Annexée............... 52,53

in Luxemburg...................63-64

exports of, from Belgium.............. 105

from French Lorraine.......... 13-14,40-42

from Lorraine Annexée............. 53-54

from Luxemburg. . ............... 63

imports of, in to Belgium......... 85-86,97,105

into Luxemburg.................64-65

into the Sarre district.............. 72,77

occurrence of, in the Sarre district...... 72

production and reserves of, in Belgium. . 84-85

in French Lorraine...... 16-19, 32,37-38,40

in Lorraine Annexée . 17,32,51,53-54,57-58

in Luxemburg........ 17,32,59,60,62,63,68

Iron and steel products, exports of, from Belgium ...................... 105

imports of, into Belgium............... 105 output of, in Belgium...... 82-83,102-103,104 in Luxemburg...................66, 68 Iron and steel works, damage to. 9-10,32,33,106-109 See also Capital.

Italy, miners from

\section{L.}

Labor. See Workmen

Lands, coal, values of and holders of concessions in.............. 30,79,112-121

iron, rentals of and holders of concessions in ............ $28-30,38-39,43-48$, $51-52,55,57-58,60-61,65,74-75,111$

Liége Province, Belgium, coal mining in.... 88, $90,118,121$

coke produced in ............. 93

Limburg Province, Belgium, coal beds in.... 88-89 Loire, Department of the, France, coal fields of ........................

Longwy district, French Lorraine, iron ore in . .........................

Lorraine Annexée, position of, in the iron industry of Europe............ 50-51 See also Capital, Coal, Iron ore, Pig iron, and Steel.

Lorraine, French, iron ore of, wheremarketed. 40-42 war damage to iron and steel works of. . . 9-10,

See also Capital, Coal, Coke, Iron ore, Pig iron, and Steel.

Lorraine iron field, area included in......... 16 deposits in, geologic features of.......... . .18

industries based on................ 13-16

volume of....................... 18-19

geographic relations of................ 19 maps of..................... in pocket.

Luxemburg, outline of iron industry of...... 59 See also Capital, Iron ore, Pig iron, and Steel.

Luxemburgers, holdings of, in companies operating coal mines and iron works in Belgium........ 106, 107, 108 
Luxemburgers, holdings of, in companies operating iron mines and works in Lorraine Annexée.

\section{M.}

McKinstry, Brig. Gen. Charles H., acknowledgment to.....................

Maps of Lorraine iron district and tributary coal fields............ 12, in pocket.

Marketing of iron and steel............... 10 iron ores....................... 10,40-42,63 See also exports and imports under the several products.

Meurthe-et-Moselle, Department of, coal in. . Mining. See Capital, Coal, and Iron ore.

Mons district, Belgium, coal mining in....

$$
\text { N. }
$$

Namur Province, Belgium, coal mining in.. 87-88, 91,118

Nancy district, iron ore in 38 location of

\section{o.}

Origin of this report.

Ownership of iron mines and lands Capital.

$$
\mathbf{P} \text {. }
$$

Phosphorus, content of, in iron ores of the Lorraine field........ 18, 19-20, 38, 51, 60

Pig iron, exports of, from Belgium........ 100, 105 imports of, to Belgium......... 99-100, 101, 105 production and consúmption of, in Belgium .......... 83,98-100, 101, 103, 104

in French Lorraine................ $\quad 42$

in Lorraine Annexée............. 54,57-58

in Luxemburg..................... 64-66

in the Sarre district................ 77-78

Plants, iron and steel, destruction and restoration of...... 9-10,32-33,34-35, 106-109 See also Capital.

Production. See Coal, Coke, Iron ore, Iron and steel products, Pig iron, and Steel:

Profits of companies operating iron and coal mines and iron works in Belgium................ 31, 83, 122-124

of companies operating iron mines and works in French Lorraine..... 30-31,39

iron mines and works in Lorraine Annexée...................... 30-31

iron and steel works in Luxemburg. . 31,69 in the Sarre district............ 30-31

- Prussian Government, ownership by, of coal lands and mines and coking plants in the Sarre district. $30,74,77,79$
R.

Page.

Railroads, condition of................... 34

Rheinland, export of iron ore to........... 35-37

Rhine, coal fields west of................. 25

Roesler, Max, acknowledgment to........... 13

Rumelange Basin, Luxemburg, iron ore in.. 60

\section{$\mathrm{S}$.}

Sarre coal field, use of,coal and coke from.... 25,77 western extension of.................. 24 Sarre district, cession, boundaries, and government of............... 70-72

See also Capital, Coal, Coke, Iron ore, Pig iron, and Steel.

Sources of information.................... 11-12

Spain, exports of iron ore from.............. 15-16

Steel, exports of, from Belgium............ 105 imports of, into Belgium............... 105 production of, in Belgium....... 82-83, 101-103 in Europe...................... 14 in French Lorraine............ 42,49-50 in Lorraine Annexée............ 54,57-58 in Luxemburg.................. 65,66-67 in the Sarre district................ 77-78

Sweden, exports of iron ore from.......... 15-16

v.

Valenciennes coal field, beds and mining in. .

Valuations of mines and works, formulas used for .............

W.

Westphalia, coal field of, description and production of. ................ 24-25 exportation of Lorraine iron ore to. 35-37,40-41 freight rates and routes for Lorraine iron ore to....................... 41 importation of coal and coke from...... 36-37 use of coke produced in............. 26-27,35 Workmen, number and wages of, in blast furnaces of Luxemburg.......... 64 number and wages of, in coal mines of Belgium.................... 91

in iron mines of Lorraine Annexée.. 52, 53 of Luxemburg.................. 62

in steel works of Luxemburg........ 67 number of, in coal mines of the Sarre district...................... 76

in iron and steel works of Belgium.. 104

in iron mines and works............ 31 supply of, uncertain.................. 34 wages of, in iron mines of French Lorraine......................... 40

Works consulted, list of................. 125-127 